\title{
الأنقاس الزكية
}

\section{في حكم تفضيل الأولاد بالعطية دراسة فقهية مقارنة}

\author{
إعداد - (إد \\ د. مصطفى صلاح عبد الحميد محمد \\ هدرس الفقه المقارن بكلية الشريعة والقانون بالقاهرة
}



الأَنْفَاُُ الزَّكِيَّة فِي حُكْمِ تَفْضِيلِ الأَوْ لَادِ بِالعَطِيَّة

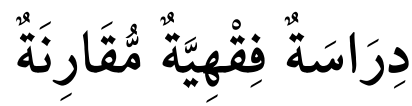

مصطفى صلاح عبد الحميد محمد.

قسم الفقه المقارن، كلية الشريعة والقانون، جامعة الأزهر، القاهرة، جمهورية مصر العربية.

البريد الالكتروني: mostafa.salah86@azhar.edu.eg

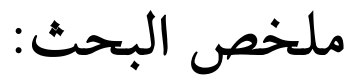

توضيح الأحكام الخاصة بقضية (تفضيل الأولاد بالعطية) من الأهمية

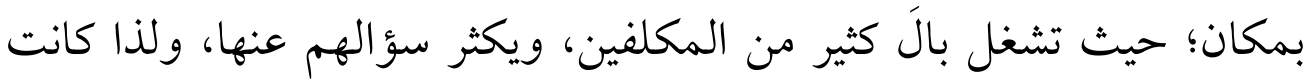

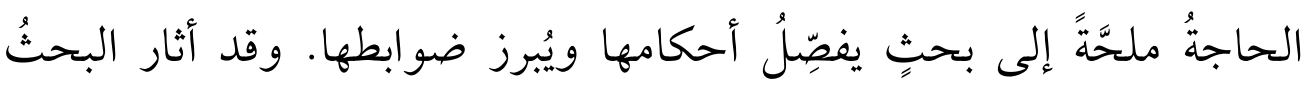

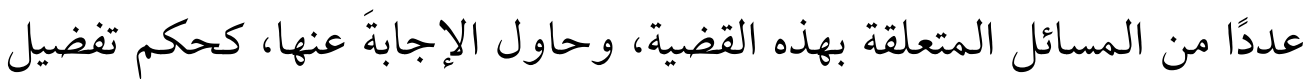

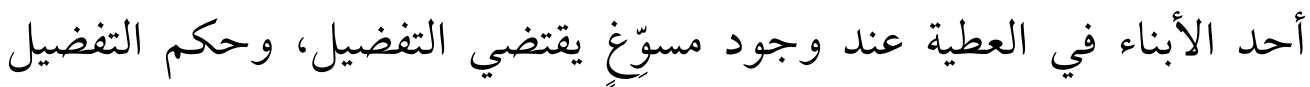

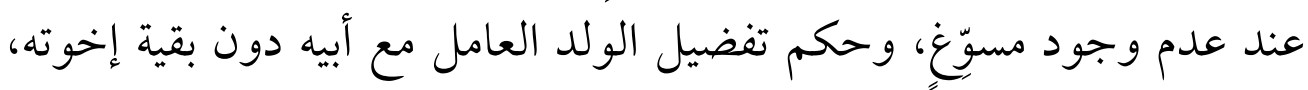

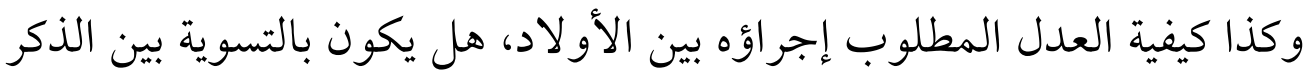

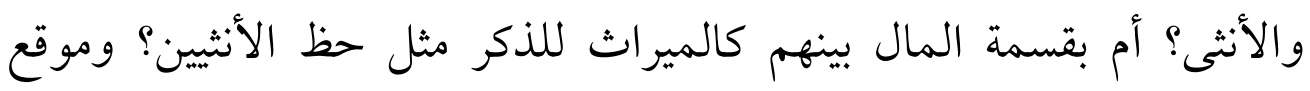

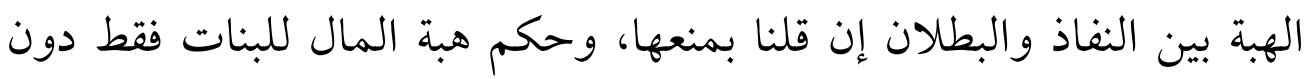

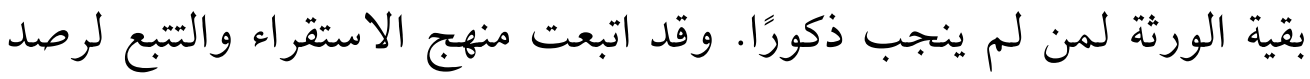

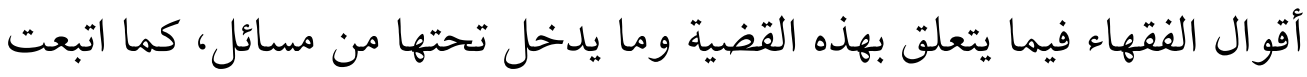
منهج الموازنة الفقهية بين الأقوال الواردة، فذكرت أقوال الفقهاء في كل 


$$
\text { مسألة، وأدلة كل قول، وما ورد على تلك الأدلة من مناقشات واعتراضات، }
$$

الكلمات المفتاحية: تفضيل، عطية، هبة، الأبناء، تمييز. 


\section{The fine breaths in provision of favoring boys with donation; a comparative jurisprudence study.}

Mostafa Salah Abdul Hameed Mohammad.

Department of Comparative Jurisprudence, Faculty of Sharia and Law, Al-Azhar University, Cairo, Egypt.

E-mail: mostafa.salah86@azhar.edu.eg

\section{Abstract:}

It's important to clarify the provisions on the case of " favoring boys with donation "; Many assigned people are concerned, and frequently asked about them, and there is therefore an urgent need for research detailing their provisions and highlighting their disciplines. It has raised a number of issues relating to this issue and has tried to answer them, such as preference for a child in a gift where there is a reason to give, preference where there is no reason, preference for a child working with his father over other brothers, and how applying equity among children by equality between males and females? Or by dividing the money between them as inheritance the male takes the double of the females? And the site of the gift is between enforceability and vanity if we say no, and the provisions on money is to be awarded only to the daughters and only to the rest of the heirs for those who have no male children.

Keywords: Favoring, Donation, Gift, Children, Discrimination. 


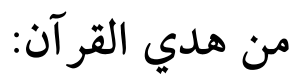

بِسْمِ اللهِ الرَّمْنَنِ الرَّحِيمِ

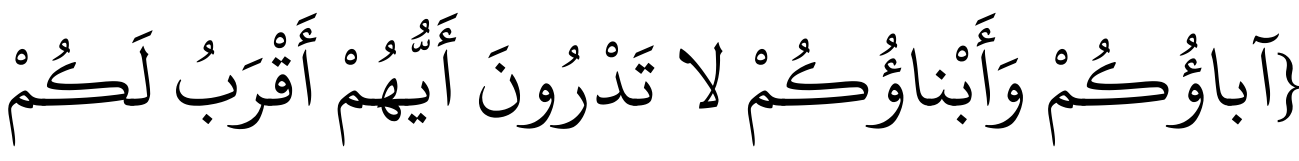

نَفْعَاً

[جزء من الآية (1) من سورة: النساء]

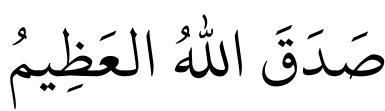




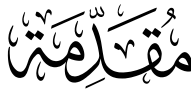

الحمد لله الذي بنعمته تتم الصالحات، الذي هدانا لهذا وما كنا لنهتدي

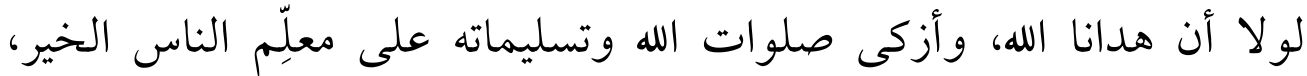

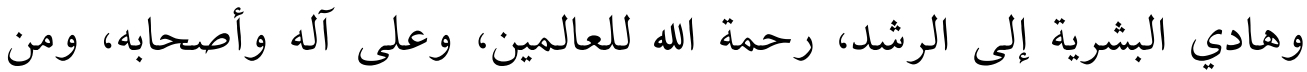
اهتدى بهديه، وسار على نهجه إلى يوم الدين .... وبعد:

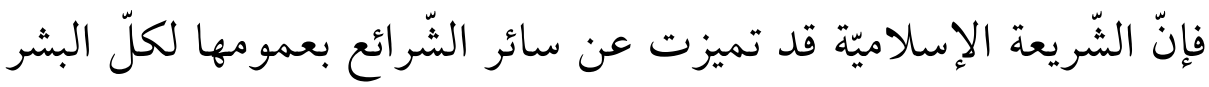

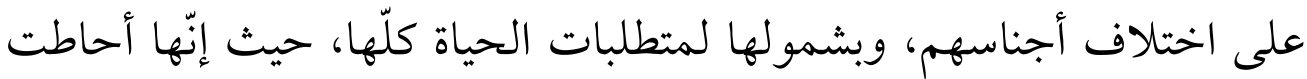

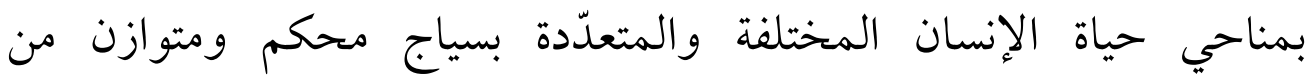

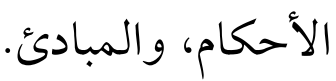

فما من شاردة ولا واردة إلا لها في كتاب الله حكمم، وصدق الله (عَنَّهَجَجَّل)

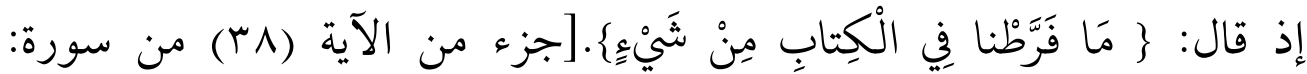
الأنعام].

ولما كانت العلاقات الأسرية هي نواة المجتمعات، بصلاحها تنصلح المجتمعات وتزدهر، وباضطرابها تضطرب المجتمعات ويختل ميزانها؛ حرص الشرع الحنيف على الحفاظ على العلاقات الأسرية، وحمايتها بسياج

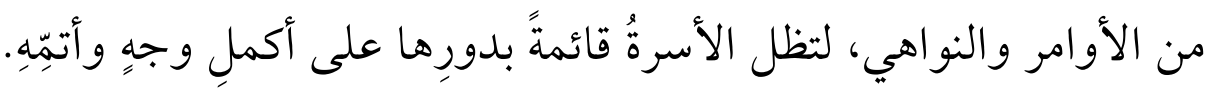
ويأتي ضمن هذا السياق: أمرُ الشريعةِ الآباءَ بعدمِ ارتكابِ أيَّة ممارسات

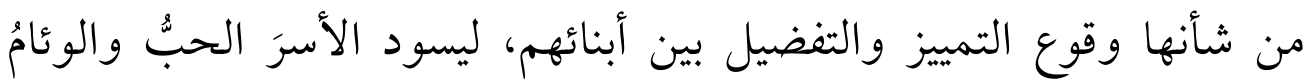
والوذُ، وتخلو من أسباب التباغض و الكراهية. 
وإن المحيط بنوازل الناس وأقضيتهم، يلمَس حاجتهم لبيان هذه المسألة الاجتماعية، حيث يكثر السؤال عنها، ويقع كثيرون في شراكها، فكان من الأهمية بمكان إلقاء الضوء على هذه القضية، بما يوضح أحكامها، فكان هذا البحث المتواضع:

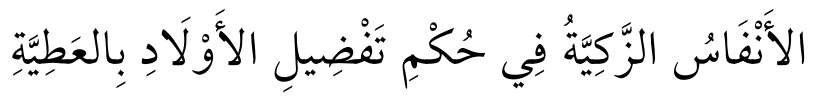

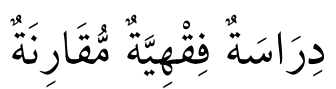

فبالله العون، وعليه التكال، ولا حول ولا قوة إلا بالله العلي العظيم ... ربنا لا تزغ قلوبنا بعد إذ هديتنا، ويسّرْ لنا العمل بما علَّمتنا، وارزقنا

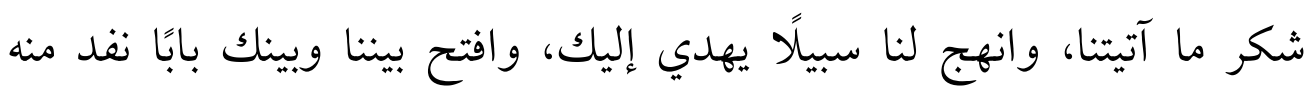
عليك؛ إنك يا ربنا حسبنا ونعم الوكيل.

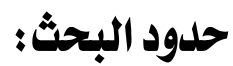

البحثُ محدودٌ بنطاقٍ مُّعينٍ لن يعدوَه، وهذه الحدود هي:

ا - تفضيل الأولاد، فلن أتعرض للكلامَ عن تفضيل غير الأولاد من

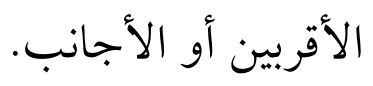

ץ- عقد الهبة للأبناء، ومن ثم فإن التصرفات المالية سوى الهبة -كالوصية

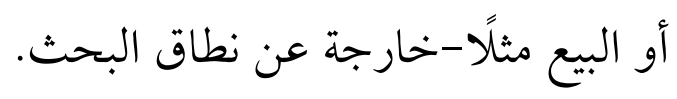

r- هبة الوالد الصحيح، أما هبة الوالد في مرض موته فخارجة عن نطاق

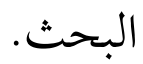

ع- مصطلح الأولاد: يشمل جنس المولود، ذكرًا كان أو أنثى، كما أن 
الحكم يعمُّ الآباء والأمهات، وليس مقتصرًا على عطية الآباء فحسب،

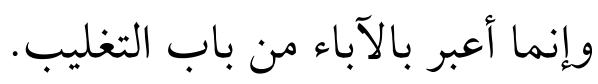

\section{أهمية البحث:}

ترجع أهمية هذا البحث إلى وقوفه على مشكلة اجتماعية حسَّاسة، يكثر

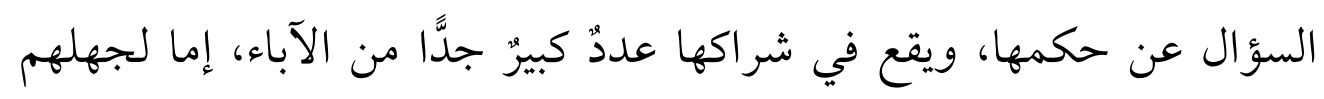

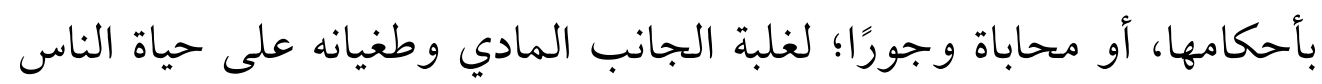

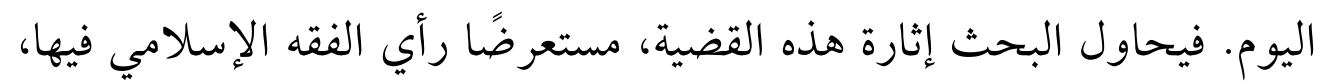

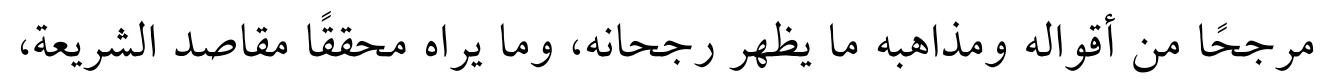

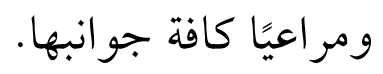

\section{منهـج البحث:}

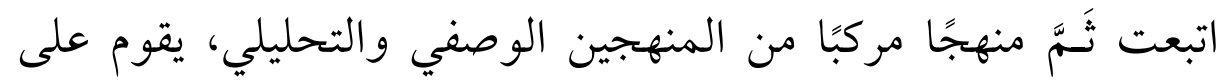
الاستقراء والمقارنة:

أولاً: الاستقراء: ومن خلاله تقطَّيتُ مذاهب الأئمة الأربعة وغيرهم من

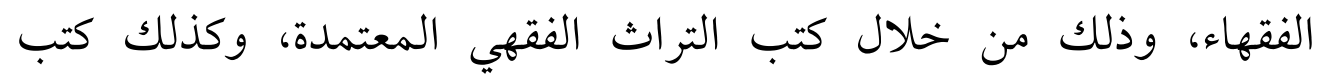
التفاسير، وشروح السنة، بغرض الوقوف على المسائل المراد بحثها، التهاء والتعرف على أقو ال فقهاء الإسلام وأدلتهم فيها.

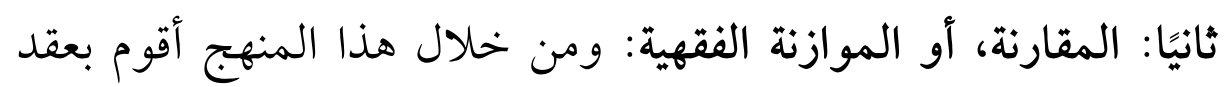

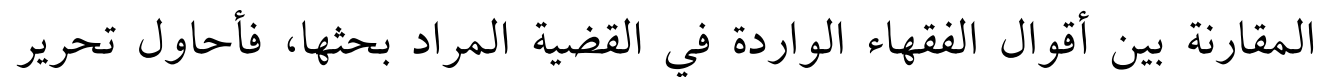

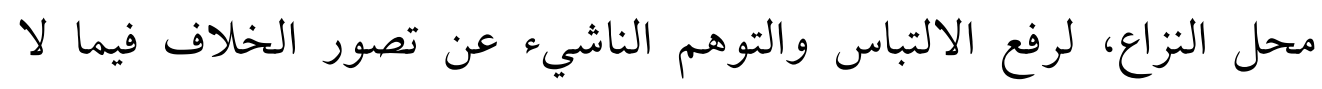

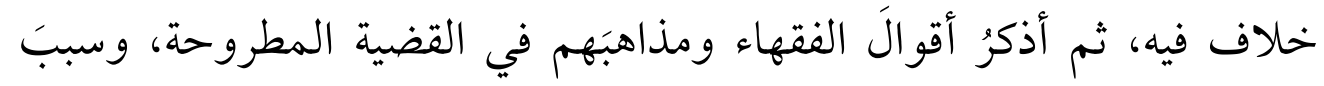


الخلاف إن وجد، ثم أستعرض أدلة كل مذهب منها، وما ورد عليها من مناقشات واعتراضات، لأصل في نهاية كل مسألة إلى القول الراجح فيها،

$$
\text { وذكر سبب الترجيح. }
$$

بالإضافة لاتباع ما تقتضيه طبيعة البحوث العلمية المتعلقة بالدراسات الإسلامية من مناهج وخطو ات ومتطلبات وأساليب بحثية.

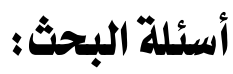

\section{يحاول البحث الإجابة عن عدد من الأسئلة، وهي:}

1 - ما المقصود بالهبة؟ وما حكمها؟ وما الفرق بينها وبين سائر التصرفات

المالية؟

r- ما حكم تفضيل الوالدِ أحََ أولاده بهبة عند وجود سبب أو مسوِغٍ يقتضي التفضيل

ب- هل يُعَدُّ الولدُ الذي أسهم في تنمية ثروة أبيه مستحِقًا للتفضيل دون

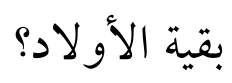

ع - ما حكم تفضيلُ الوالدِ أحدَ أولاده بهبة عند عدم وجود علة تقتضي

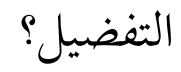

0- - ما أقوال شُرَّاح السنة وأهل الفقه في حديث النعمان بن بشير -

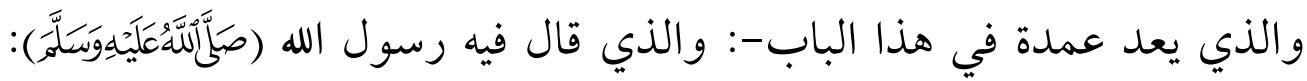

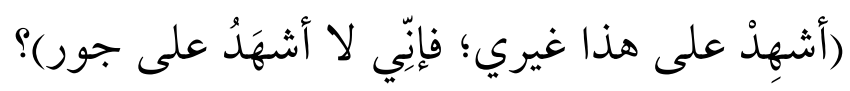
7- هل العدل بين الأولاد في العطية يقتضي التسوية بين ذكرهم وأثثاهم؟ 


$$
\text { أم يُعطَى الذكرُ ضعف الأنثى كالميراث؟ }
$$

- حكم تفضيل البنات بالهبة، دون باقي الورثة لمن لم ينجب إلا إناثًا

فقط؟

^- إلى أي مدى يعتبر الإسالام غرس قيمة الود والحب بين الأبناء، ونزع

$$
\text { أسباب الكر اهية والبغضاء بينهم؟ ليعبر الإسلمع }
$$

\section{خطة البحث}

\section{قسَّمت البحث إلى : مقدمة، وتمهيد، وسبعة مباحث، وخاتمة.}

فأما المقدمة: فجعلتها لبيان حدود البحث، وأهميته، ومنهجه، والأسئلة

$$
\text { التي يحاول البحثُ الإجابةَ عنها. }
$$

وأما التمهيد فجعلت عنو انه: قيمة العدل، وخطورة التفرقة بين الأبناء.

وأما المبحث الأول، ففي: بيان المقصود بمصطلحي (التفضيل - والهبة)

$$
\text { و وبيان حكم الهبة في الأصل. }
$$

المطلب الأول: المقصود بالتفضيل.

المطلب الثاني: المقصود بالهبة.

المطلب الثالث: حكم الهبة في الأصل.

المبحث الثاني: تفضيل الوالد بعضَ أولاده بالهبة لسبب يقتضي

التفضيل. 
> المبحث الثالث: حكم تفضيل الولد الذي عمل في مال والده، أو كان سبيًا ظاهرًا في تنميته وتكثيره.

> المبحث الرابع: تفضيل الوالد بعضَ أولاده، لغير علة تقتضي التفضيل. > المبحث الخامس: طريقة العدل بين الأولاد في العطية. > المبحث السادس: الهبة مع التفضيل (بين النفاذ والبطلان). > المبحث السابع: هبة المال للبنات عند عدم وجود أبناءٍ ذكورٍ. الخاتمة، وفيها ما انتهى له البحث من نتائج. > ثم ثبت المصادر والمراجع التي اعتمد عليها البحث.

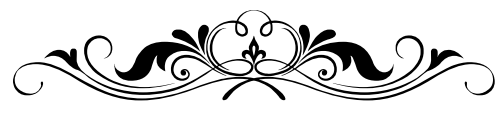


تمهيد: في

\section{قيمة العدل، وخطورة التفرقة بين الأبناء}

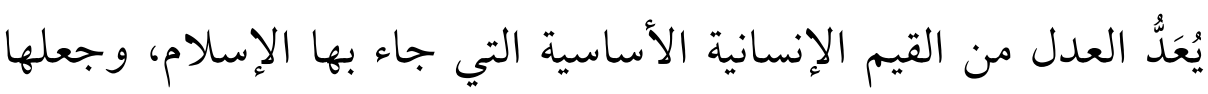

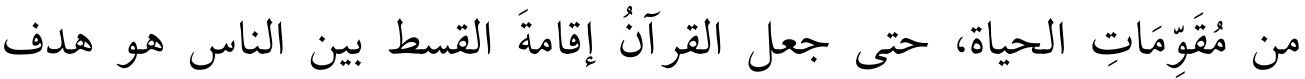

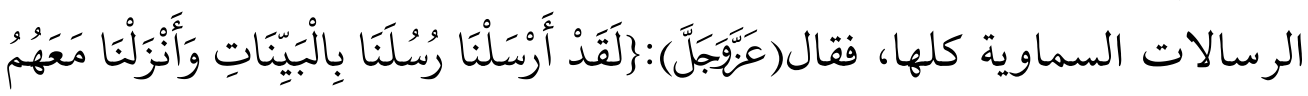

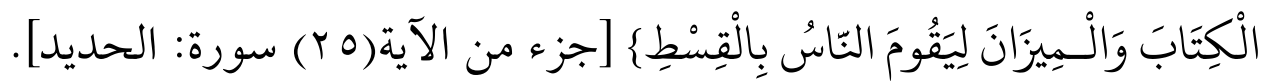

وليس ثمة تنويه بقيمة القسط أو العدل أعظم من أن يكون هو المقصود

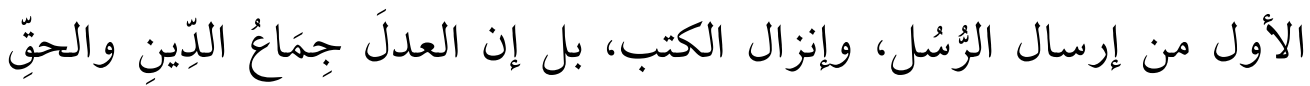

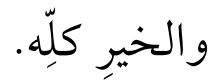

وقد روت لنا كُتُب التَّراجم والتاريخ والسّبَيَر: أنَّ بعض وُلاة الخليفة

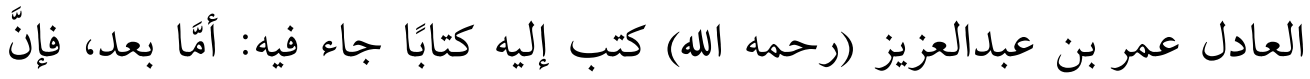

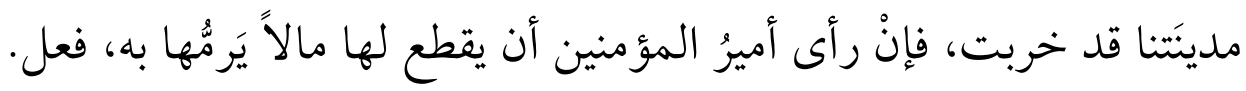
فكتب إليه عُمر (رحمه الله): (أمَّا بعد: فقد فهمتُ كتابك، وما ذكرتَ أنَّ

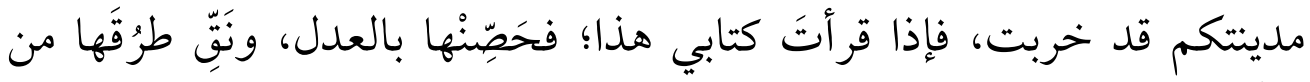

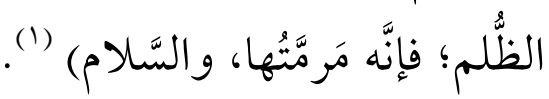
نعم، فبالعدل قامت السماوات والأرض.

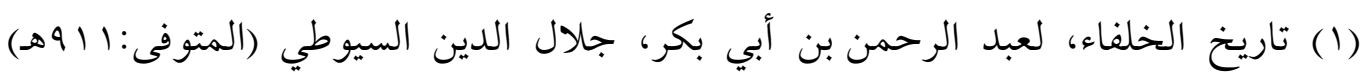

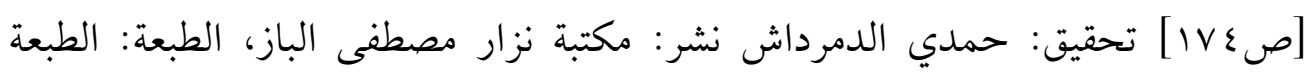

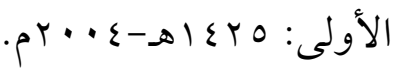




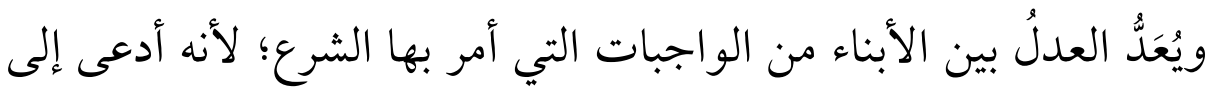

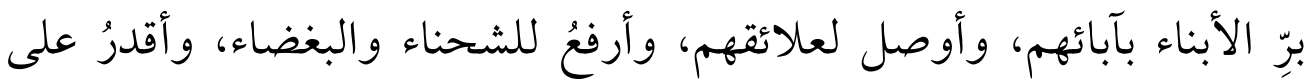

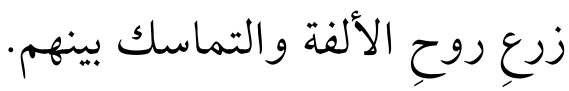

وتعدّ التفرقة بين الأبناء من الأسباب التي تؤدي إلى عقوق الوالدين،

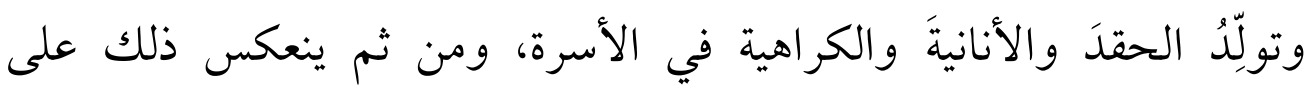

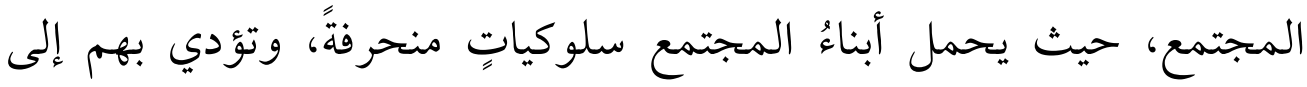

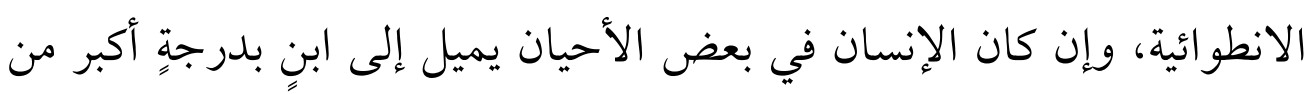

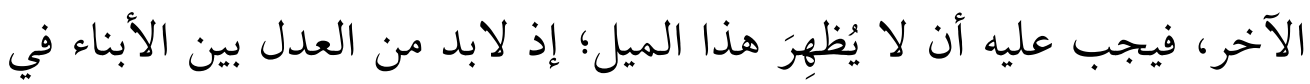

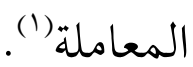

فإن (العديد من الجرائم الأسرية يتحمل وزرها آباء وأمهات تجاهلوا

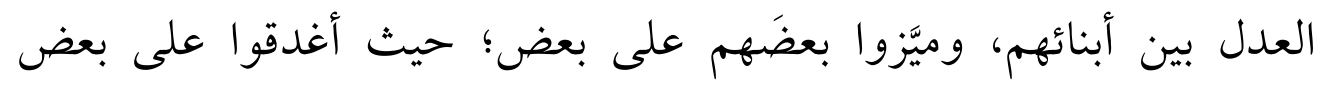

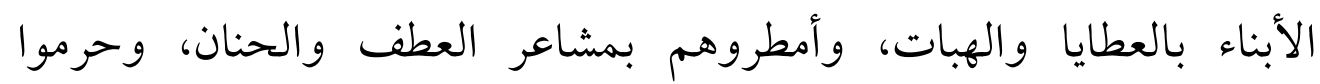

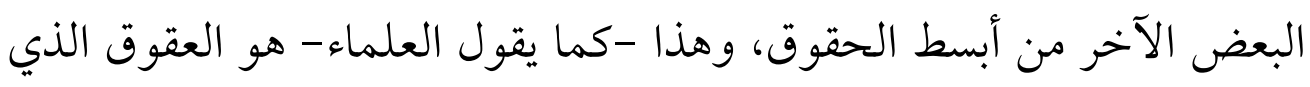
يمارسه الآباء، وهو لا يقل خطورة عن عقوق الأبناء)(ب).

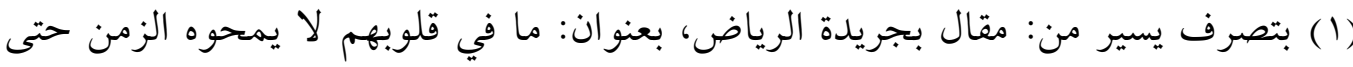

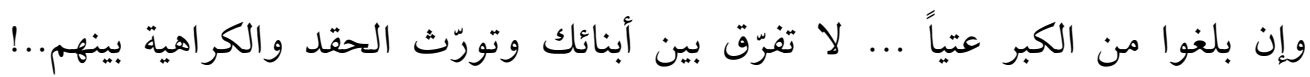

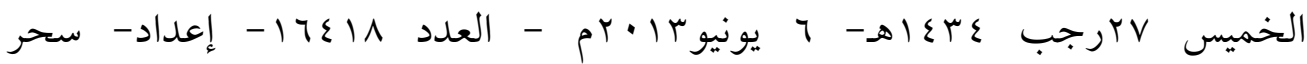
الرملاوي. ينظر النسخة الالكترونية على الرابط التالي: http://www.alriyadh.com/841515

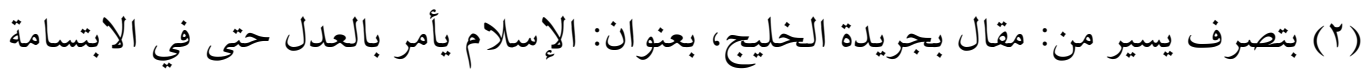

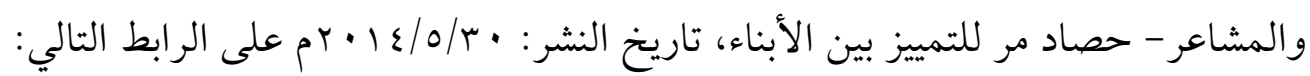
http://www.alkhaleej.ae/supplements/page/b4b9ae91-abac-4599- 
ولذا فقد بالغ بعض أئمتنا في التحذير من خطورة هذا الأمر، حتى

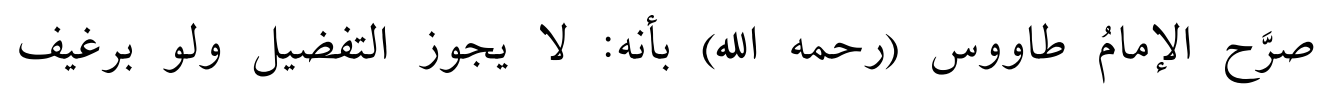
محترق" (1)

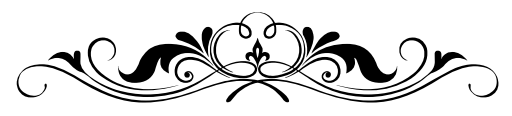

863e-50372d57104f

(1) المغني، لأبي محمد موفق الدين عبد الله بن أحمد بن محمد بن قدامة الجماعيلي

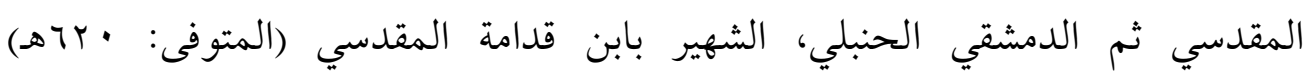

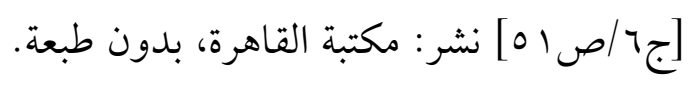

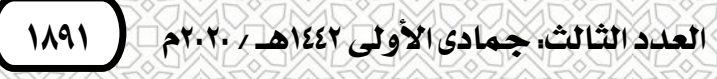


المبحث الأول

بيان المقصود بمصطلحي (التفضيل -والهبة) وبيان حكم الهبة في

(الأصل (1) (1)

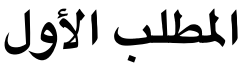

\section{المقصود بالتفضيل}

الفضلُ والفضيلة: ضد النقص والنقيصة، والجمع: فضول، والتفاضل

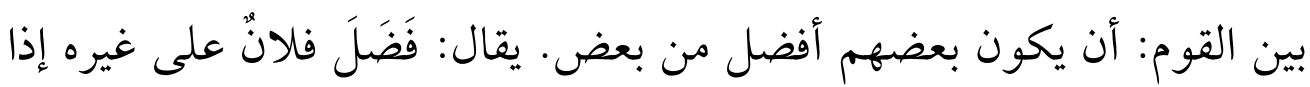

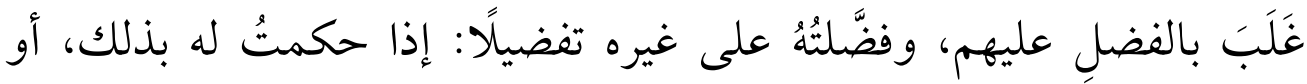

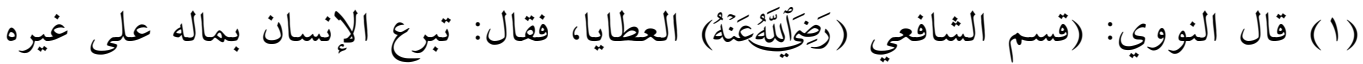

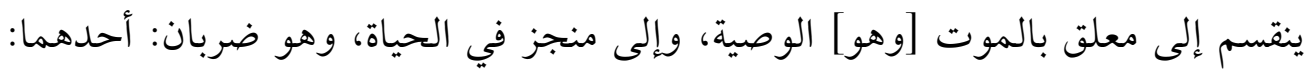

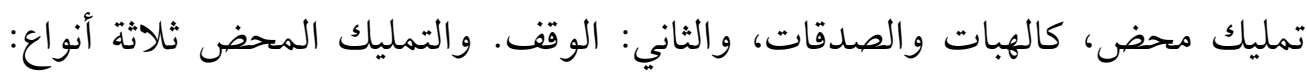

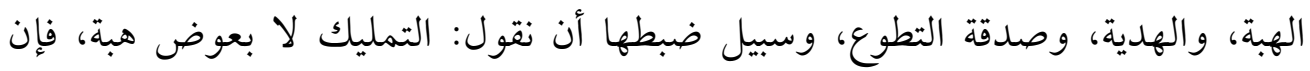

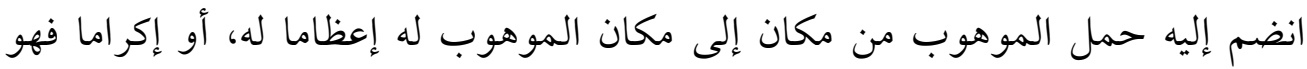

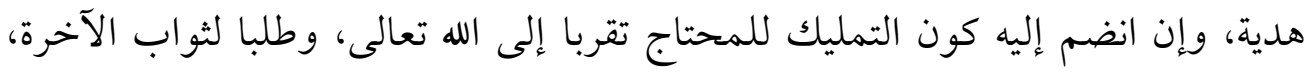

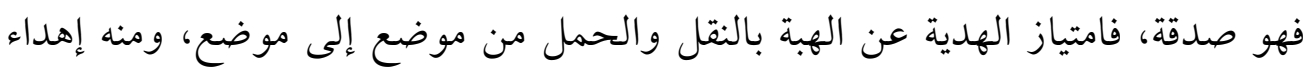

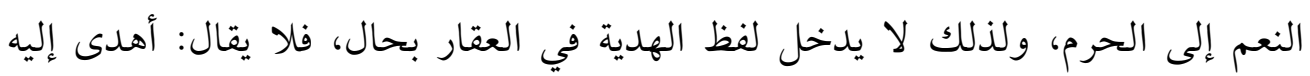

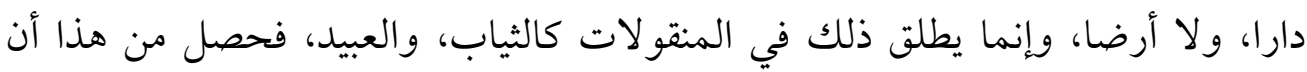

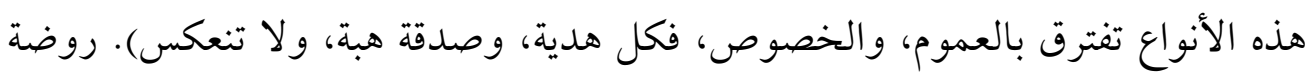

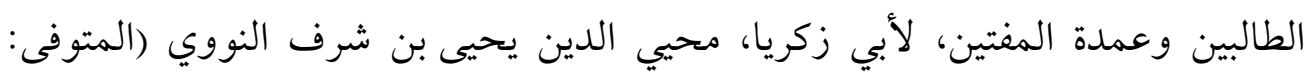

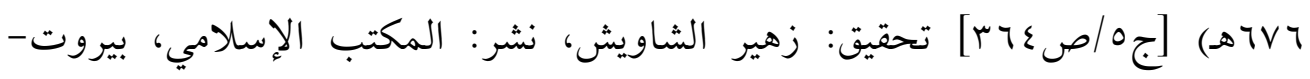

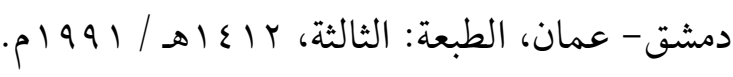


صيَّرته أفضل منه، وفضَّله على غيره تفضيلًا: مزَّاه، أي: أثبت له مزية، أي خصلة تميزه عن غيره (1).

والمراد بالتفضيل فيما نحن بصدده: حصول التمييز في العطية من

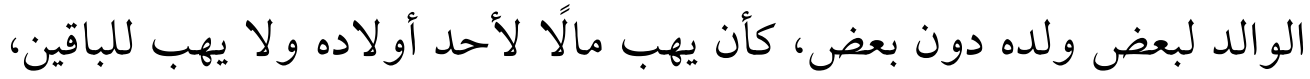

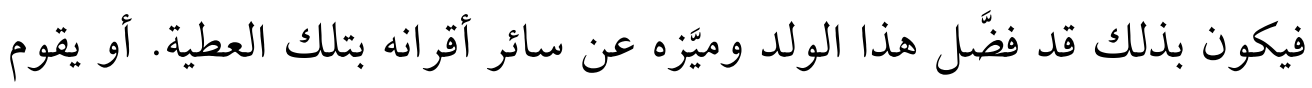

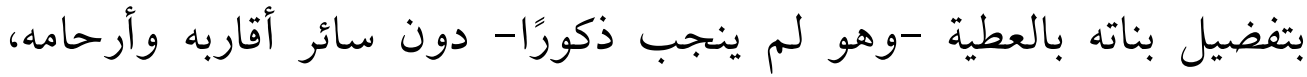

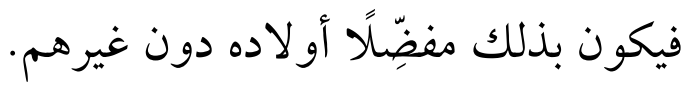

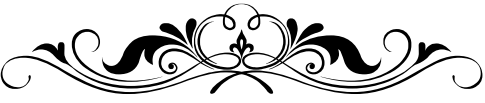

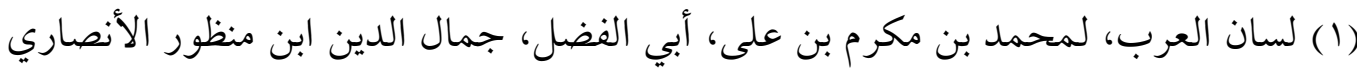

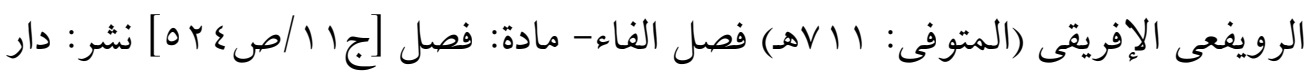

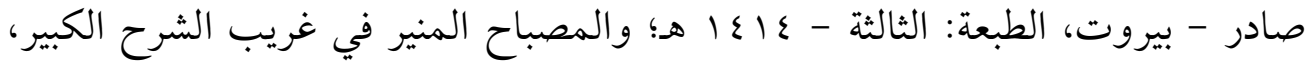

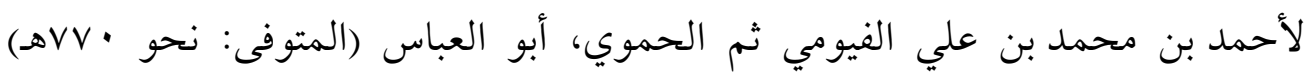

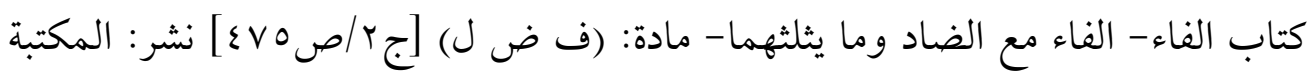

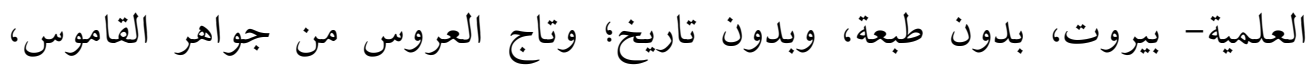

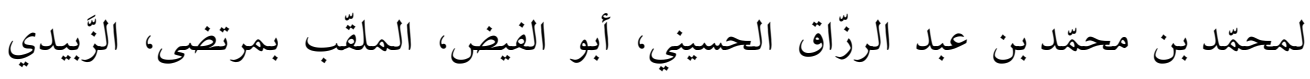

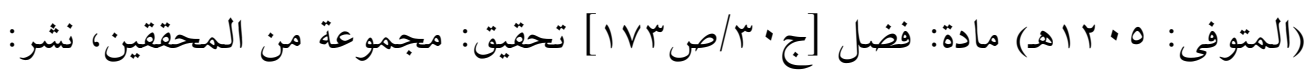

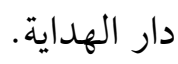




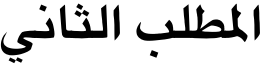

\section{المقصود بـالهبة، أو العطية}

\section{أولًا : تعريف الهبة في اللفة :}

الهبة: أصلها من الوَهْبْ بتسكين الهاء وتحريكها، ومعناها: إيصال الشيء إلى الغير بما ينفعه، وقد تكون بالعين، وقد تكون بالدين، وقد تكون

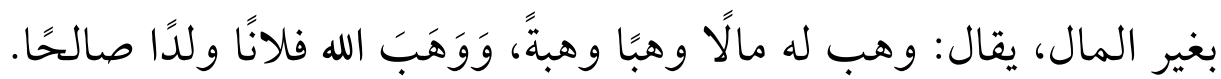

أصلها من هبوب الريح، أي: مروره، ويحتمل أنها من: هبَّ من نومه إذا

استيقظ، وكأن فاعلها قد استيقظ للإحسان (1).

(1) قال القرافي: (أسماء أنواع الإحسان في اللغة العربية: - هبة الثمار في النخل والأشجار. - والعارية: تمليك المنافع. - مالإفقار: إعارة الظهر من بعير أو غيره للركوب -مأخوذ من فقار الظهر، وهو عظام سلسلة الظهر - .

- موالمنحة والمنيحة: تمليك لبن الشاة مدة تكون عنده يحلبها. - ـ و الهبة: تمليك الأعيان؛ طلبًا للوداد. - و الصدقة: تمليك الأعيان؛ للثواب عند الله تعالى. - موالسُّكنى: هبة منافع الدار مدة معينة، وهو أحد العارية. - والعُمرَى: تمليك منافع الدار عمره.

- موالرُّقبى: تمليك منافع الدار إلى أقربهما موتًا، كأنَّ كلَّ واحد منهما يرتقب موت صاحبه.

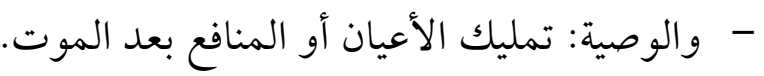
- موالوقف والحبس: تمليك الموقوف عليه أن ينتفع بالأعيان، لا تمليك المنافع. وفرق بين

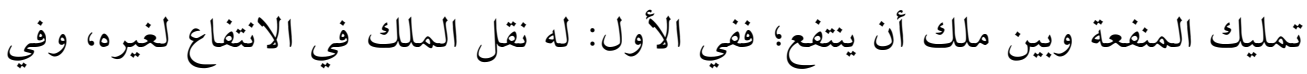
الثاني: ليس له ذلك، كالجلوس في المساجد للصلاة، وفي الطرقات للمعاش، وليس له 
والهبة: العطية الخالية عن الأعواض والأغراض، فإذاذ كَثُرتْ سُمِّيَّي

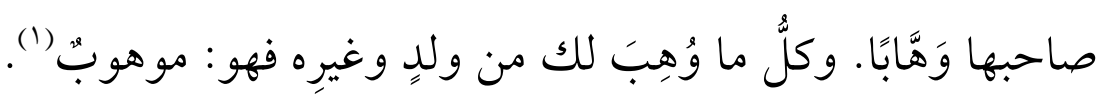

$$
\text { بيع ذلك ولا تحجيره. }
$$

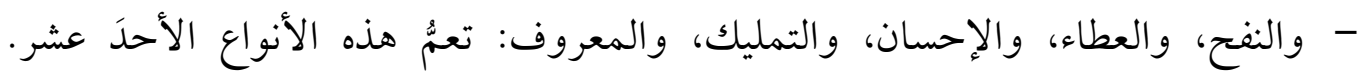

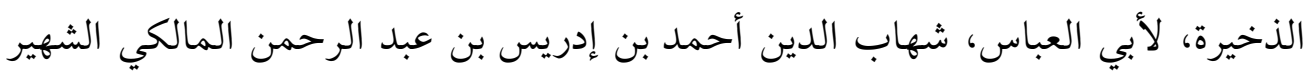

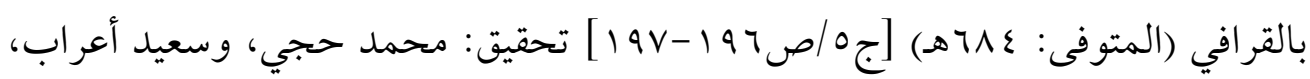

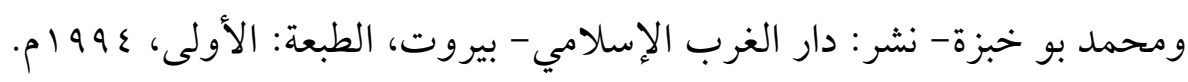

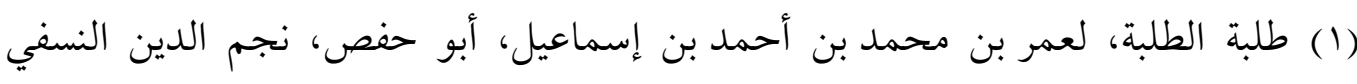

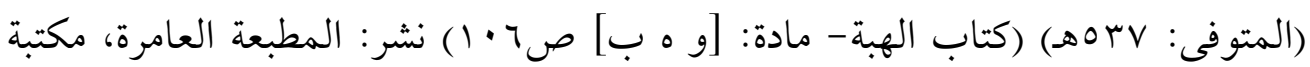

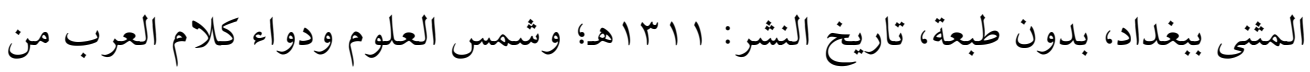

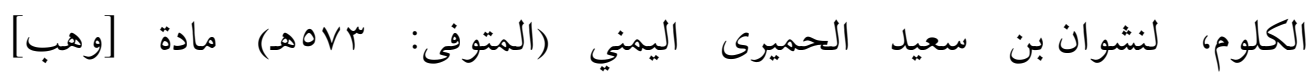

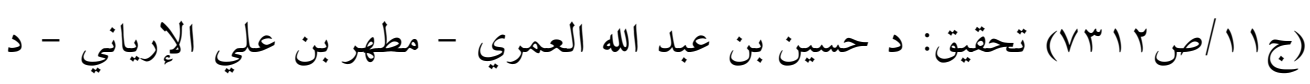

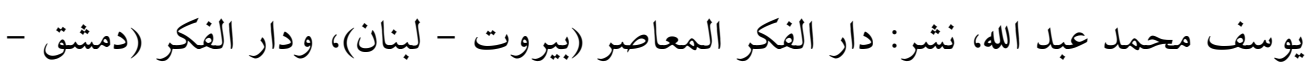

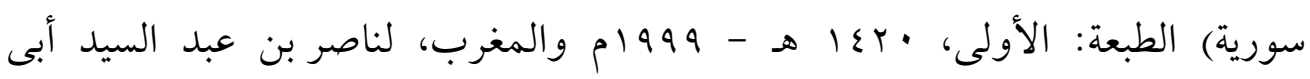

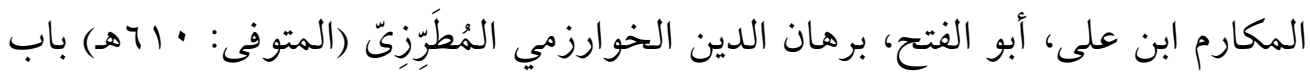

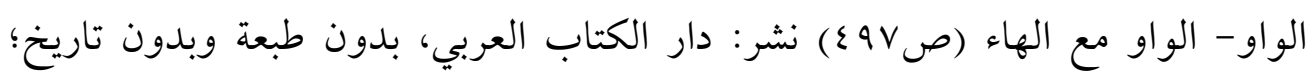

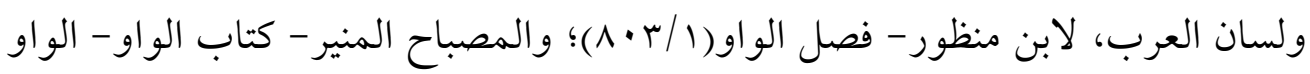

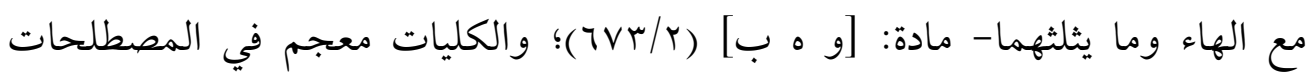

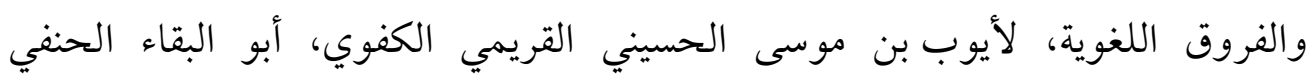

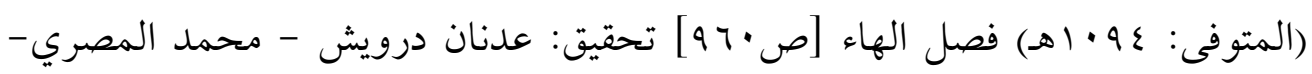

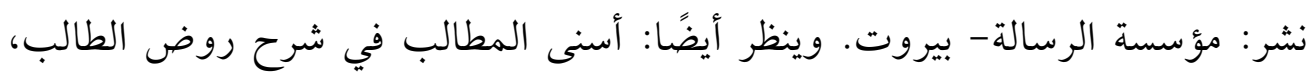

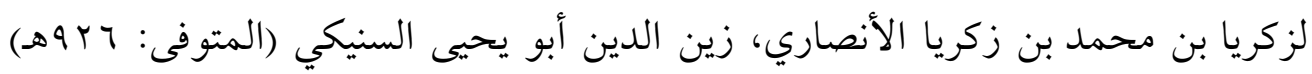

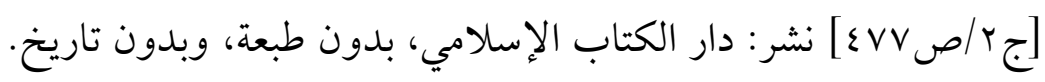




\section{ثانيًا : تعريف الهبة في اصطلاح الفقهاء :}

عرفها فقهاء الحنفية الهبة بأنها:

العطية الخالية عن تقدم الاستحقاق (1).

وقيل: تمليك العين بلا عوض (r).

وقيل: تمليك العين مجانًا للحال [لإخر اج الوصية]

(1) الاختيار لتعليل المختار، لعبد الله بن محمود بن مودود الموصلي البلدحي، مجد الدين

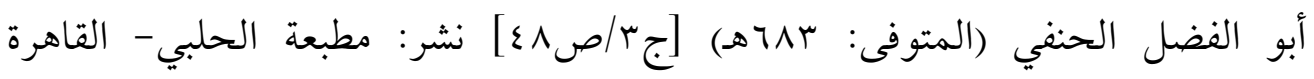

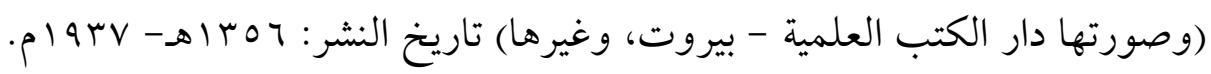

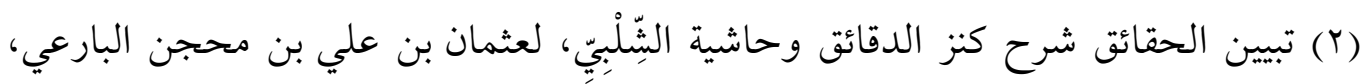

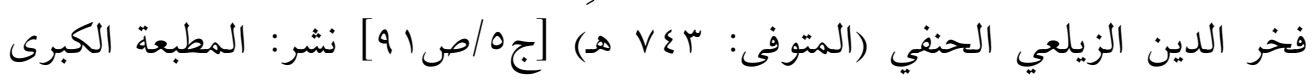

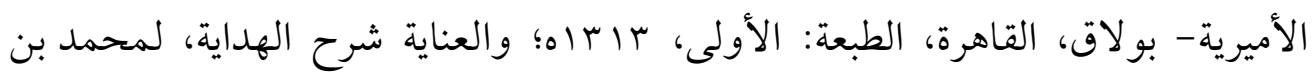

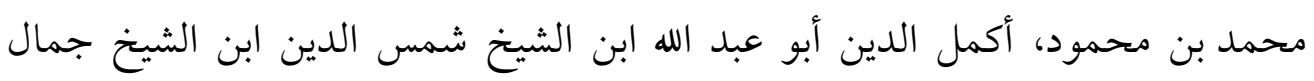

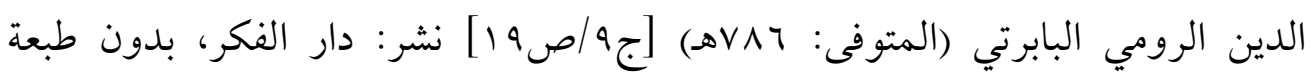

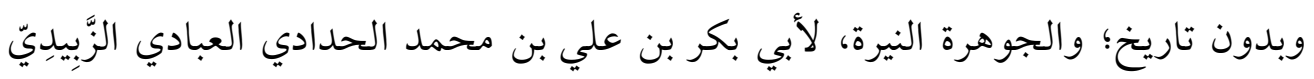

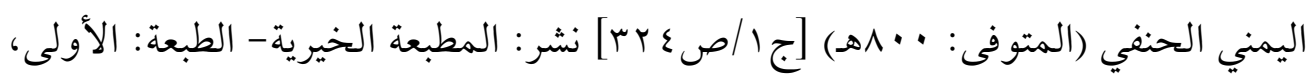

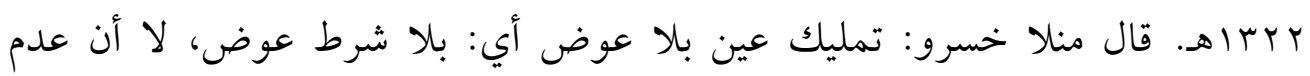

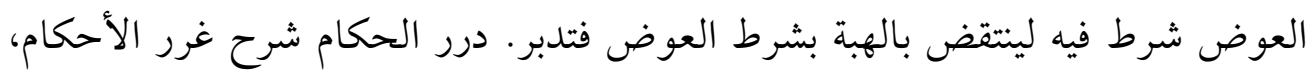

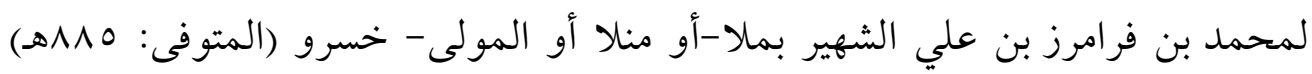

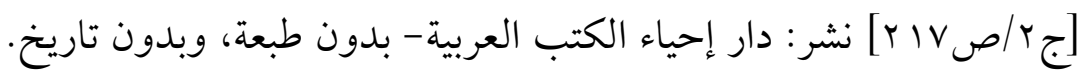
(rr) رد المحتار على الدر المختار، لابن عابدين، محمد أمين بن عمر بن عبد العزيز عابدين

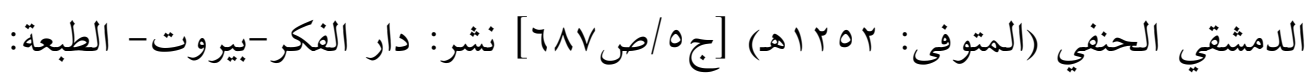

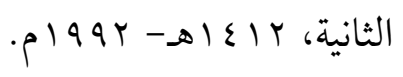


وعرَّفها فقهاء المالكية بأنها:

تمليك شيء باكلا عوضى (1).

وقيل: الهبة أحد أنواع العطية، وهي: تمليك شمول بغير عوض إنشائي م(r).

وعرفها فقهاء الشافعية بأنه:

تمليك العين بغير عوضى (r).

(1) مختصر خليل، لخليل بن إسحاق بن موسى، ضياء الدين الجندي المالكي المصري

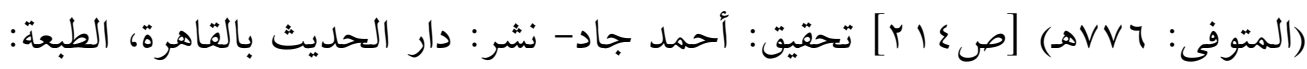

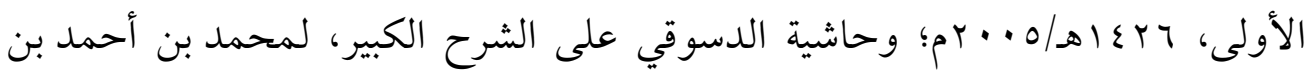

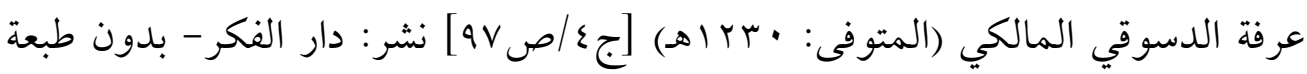

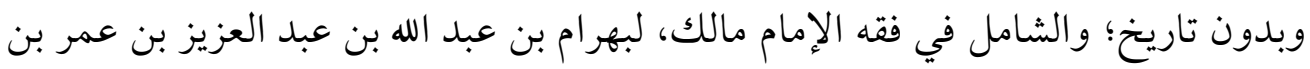

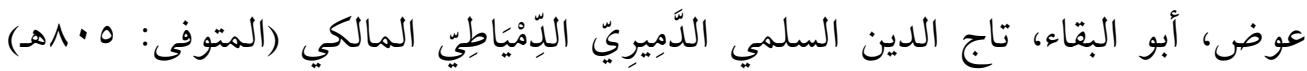

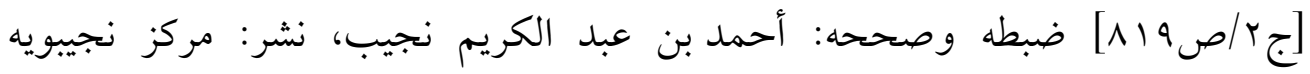

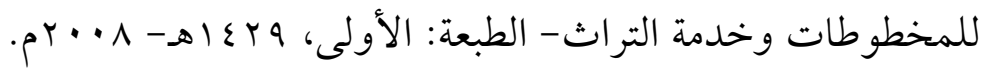
(r) التاج والإكليل لمختصر خليل، لمحمد بن يوسف بن أبي القاسم بن يوسف العبدري

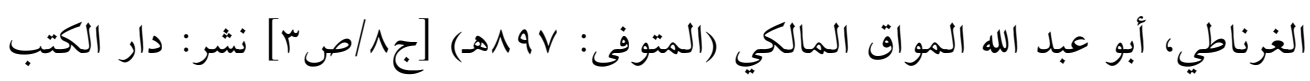

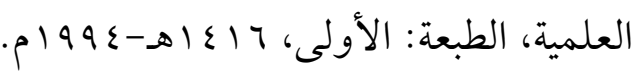
(r) البيان في مذهب الإمام الشافعي، لأبي الحسين، يحيى بن أبي الخير بن سالم العمراني

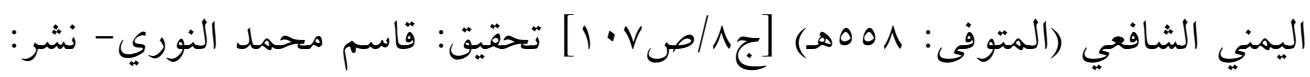

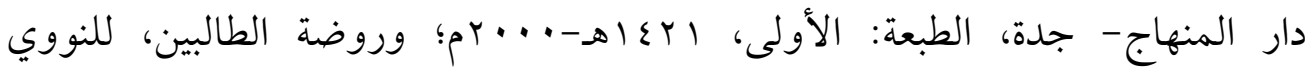

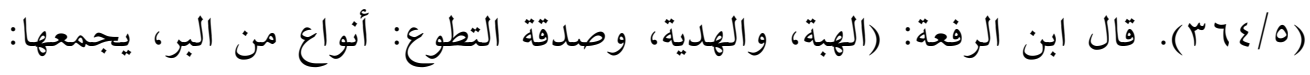
تمليك العين من غير عوض، فإن تمَّحض فيها طلب الثواب من الله تعالى بإعطاء محتاج

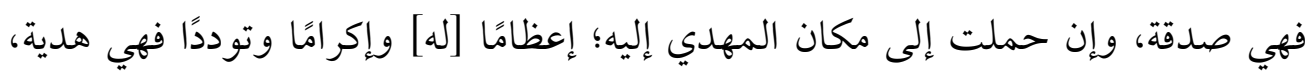
وإلا فهبة). كفاية النبيه في شرح التنبيه، لأحمد بن محمد بن علي الأنصاري، أبوٍ 
وقيل: تمليك تطوع في حياة، لا لإكرام، ولا لأجل ثواب أو احتياج

بإيجاب وقبول (1)

وعرفها فقهاء الحنابلة بأنها:

• تمليكُ مالٍ في صحته، لا في مقابلة مال (؟).

وقيل: التبرع بتمليك مال في حياته (ب).

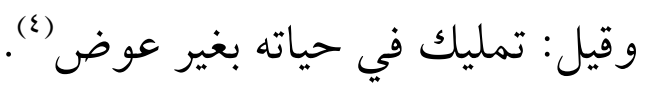

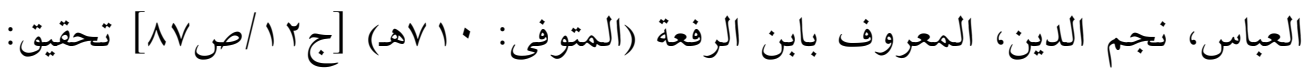

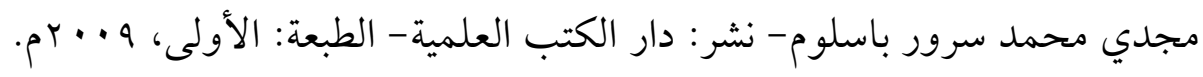

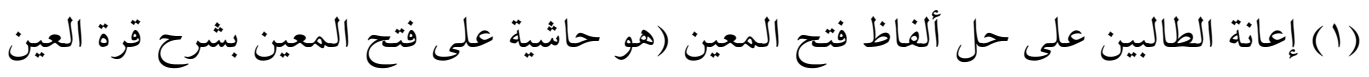

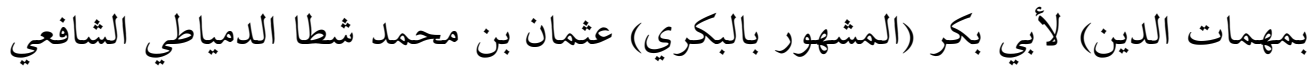

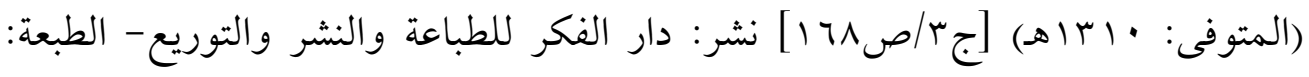

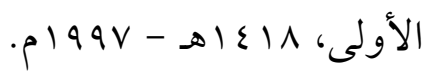

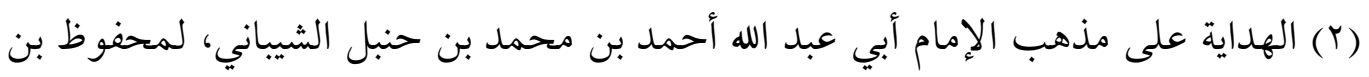

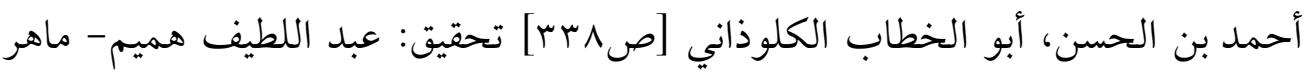

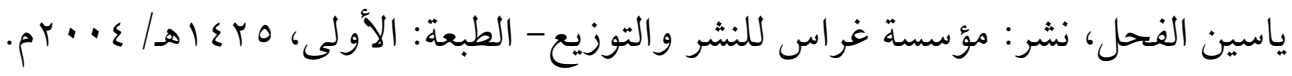

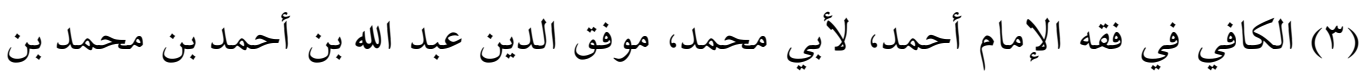

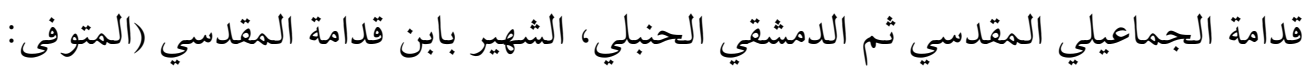

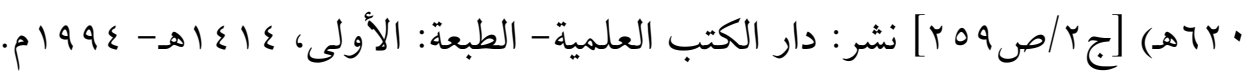

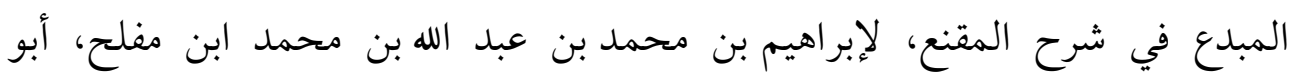

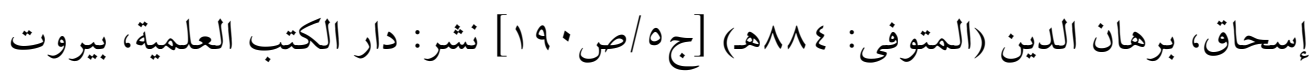

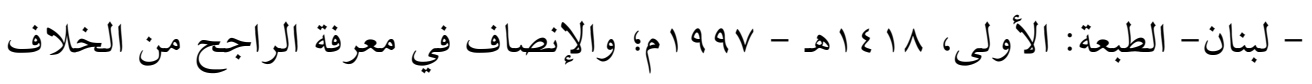

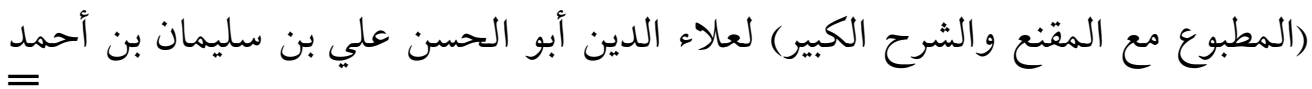


وقيل: تمليك جائز التصرف مالًا معلومًا، أو مالًا مجهولًا تعذر علمه (1).

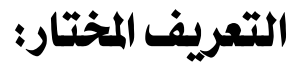

مما سبق يتضح أن فقهاءنا (رحمهم الله) أبرزوا في تعريفاتهم للهبة عددًا من المعاني المميّزة لهذا التصرف عن غيره من التصرفات المالية التي قد تشتبه به، ومن هذه المعاني البارزة:

• أن الهبة فيها نقل لملكية المال الموهوب من ذمة الواهب إلى ذمة الموهوب له، لتخرج الإجارة والإعارة وما ماثلهما من كل ما يبيح المنفعة أو الانتفاع دون نقل الملكية. أن الهبة تكون حالَ حياةِ الواهِبَ، ويتم قبضها في الحال، وتنتقل العين الموهوبة من ذمة الواهب إلى ذمة الموهوب فور انعقاد الهبة؛ لئلا يلتبس عقد الهبة بعقد الوصية الذي لا ينفذ إلا بعد وفاة الموصِي.

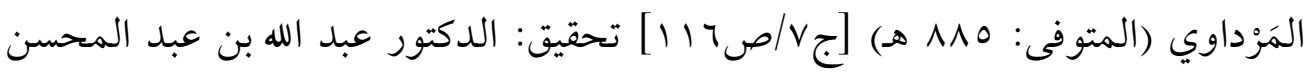
التركي - الدكتور عبد الفتاح محمد الحلو- نشر: هجر للطباعة والنشر والتوزيع

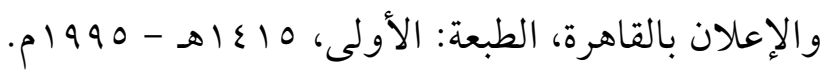
(1) دقائق أولي النهى لشرح المنتهى المعروف بشرح منتهى الإرادات، لمنصور بن يونس بن يونس بن صلاح الدين ابن حسن بن إدريس البهوتى الحنبلى (المتوفى:

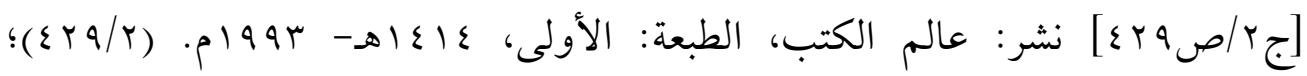
ومطالب أولي النهى في شرح غاية المنتهى، لمصطفى بن سعد بن عبده السيوطي شهرة،

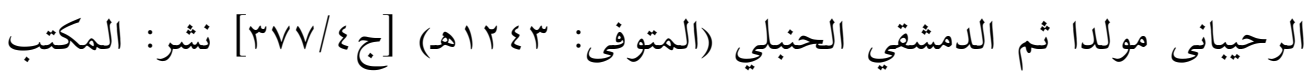

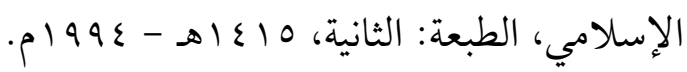


• أن الهبة تكون في حال الصحة؛ لأن تصرف المريض مرض الموت

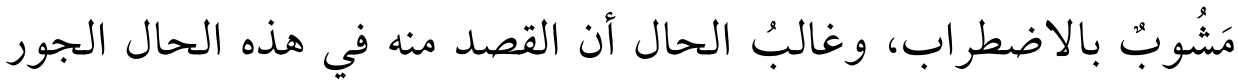
على بعض الورثة بحرمانهم من ماله بعد وفاته أو تقليل أنصبائهم.

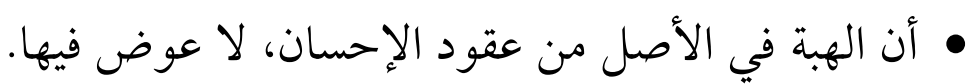
ومن ثم، فلا مانع من تعريف الهبة بأنها: تمليكُ المالِ بلا عوضِ، حالَ حياةِ المالكِ، وصحَّنِّه.

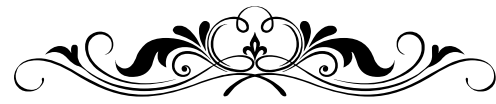




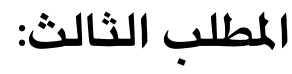

\section{حكم الهبـة في الأصل:}

عقد الهبة في الأصل عقدُ جائزّ، وقد انعقد الإجماع على أنه مستحبُّ

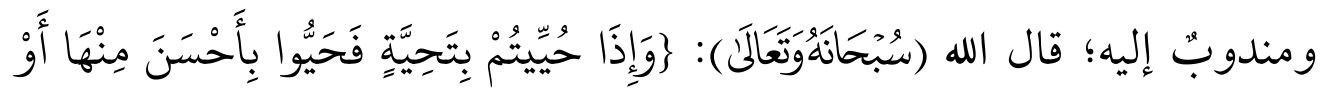

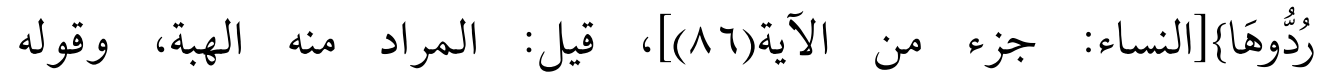

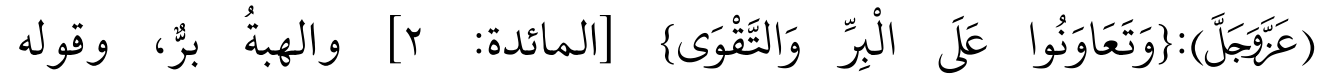

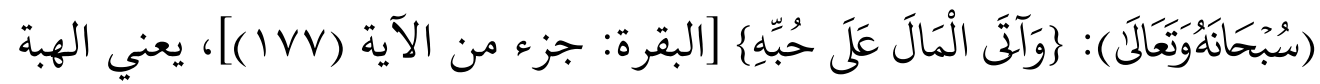
والصدقة، وقد وردت أخبار كثيرة تدل على ذلك (1).

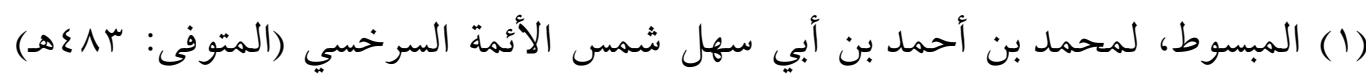

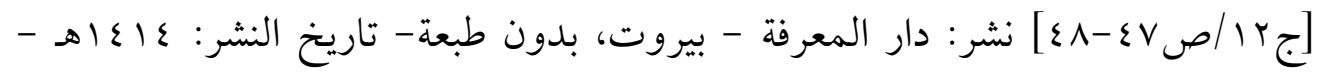

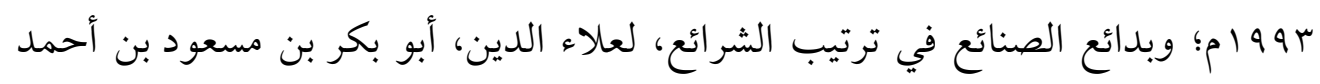

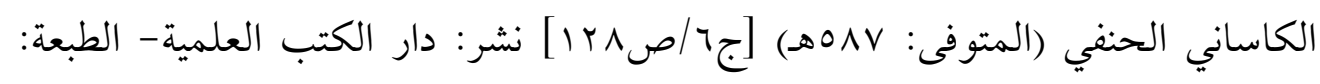

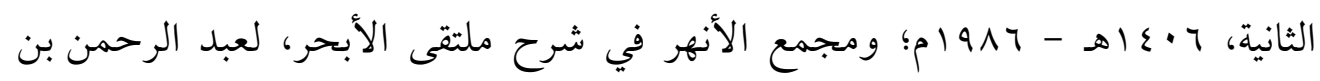

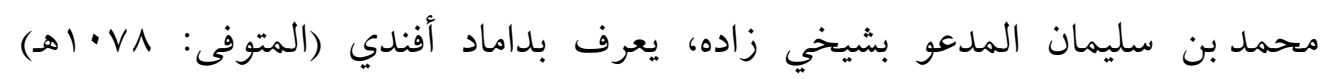

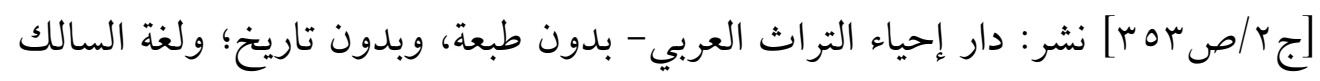

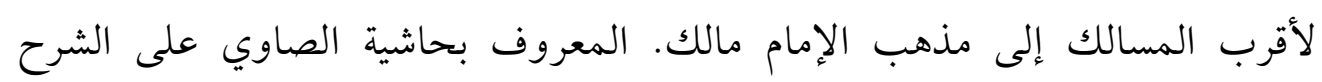

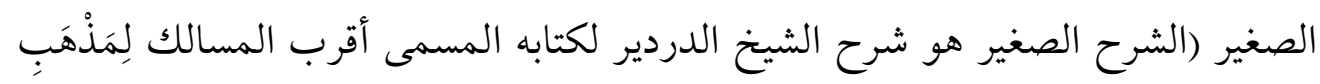

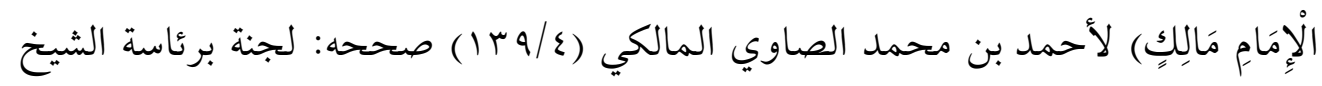

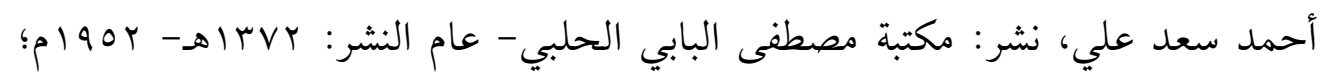

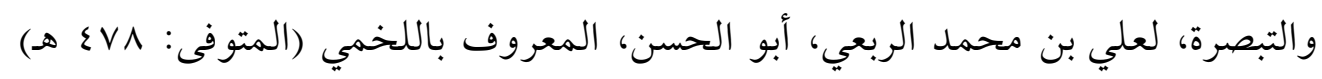

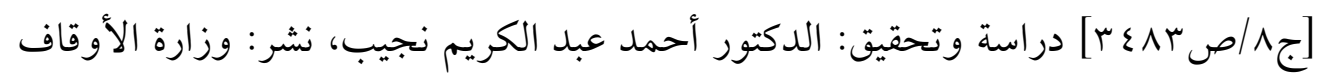

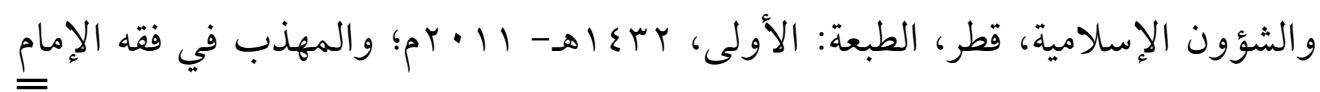


ولأنه من باب الإحسان، واكتساب سبب التودُّدٍ بين الإخوان، وكل

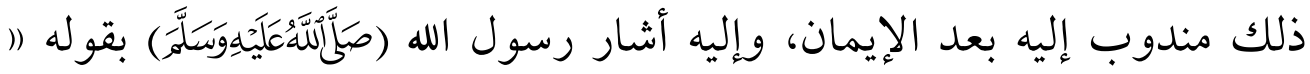

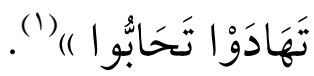

وقد قيل: إن الهدية مشتقة من الهداية؛ لأنه اهثُدى بها إلى الخير وإلى

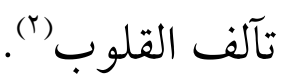

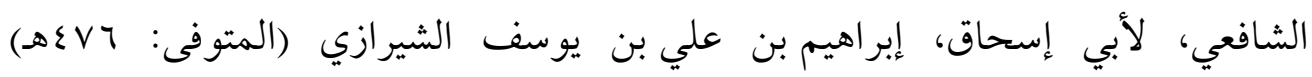

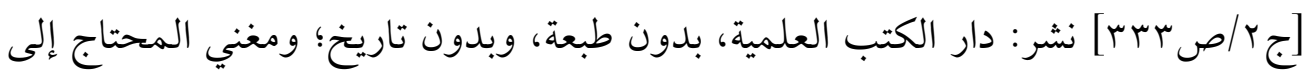

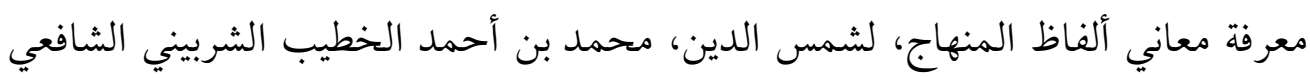

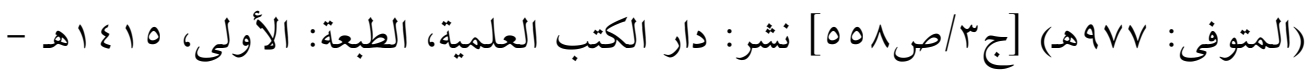

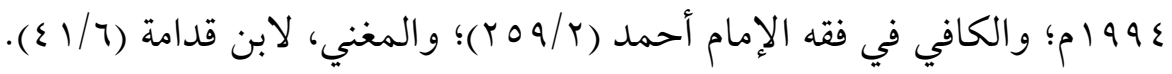

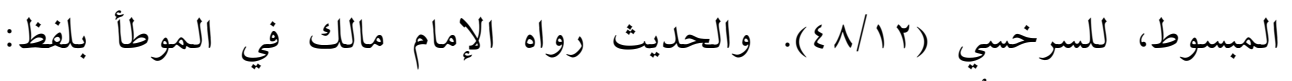

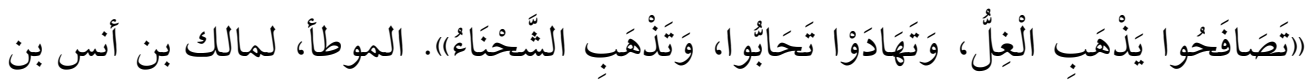

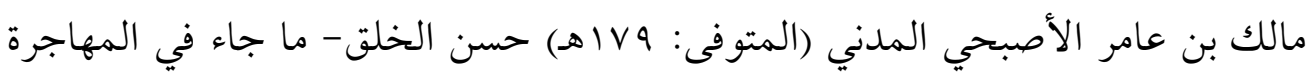

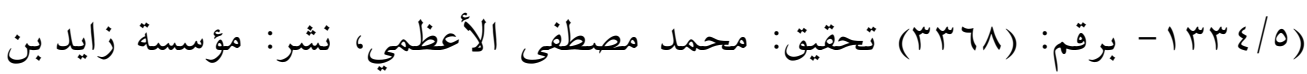

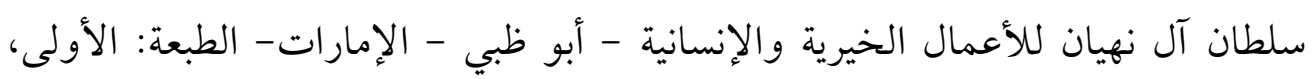

.

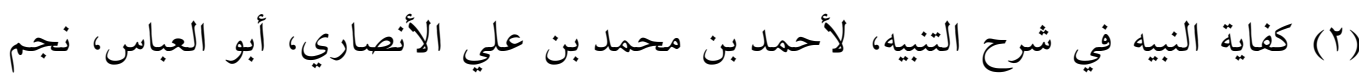

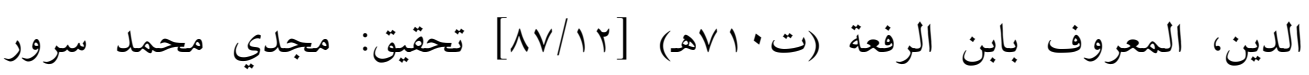

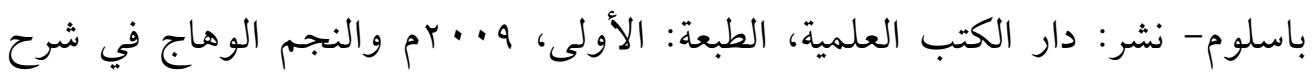

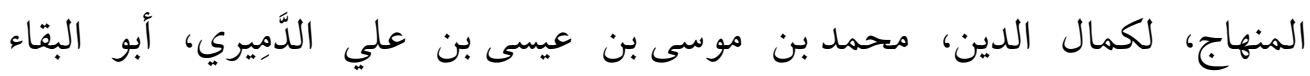

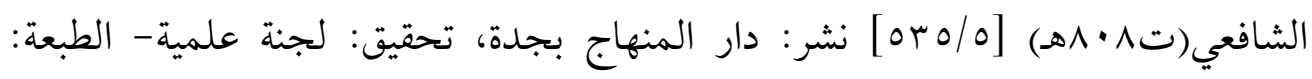

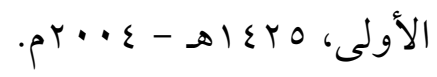


وقد قال بعضهم (1):

هدايا الناسِ بعضهم لبعض ت*** تولـد في قلوبهـم الوصـالا وتزرع في القلوب هؤى وودًّا **** وتكسوهم إذا حضروا جمـــالا وقال أبو الفتح البستي: لا شيءَ أدفع للإحن والعداوات والضغائن

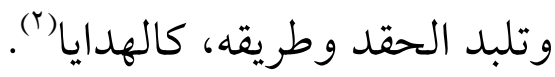
و الهبة للأقارب أفضل؛ لقول الله تعالى :

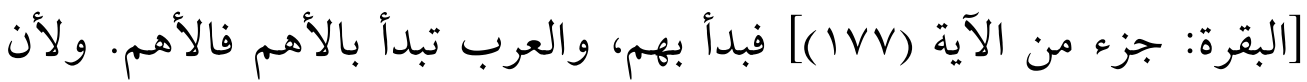

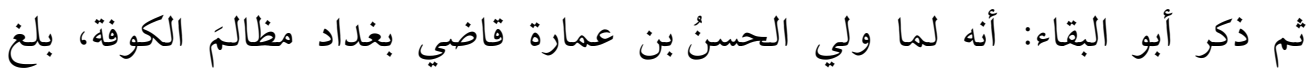

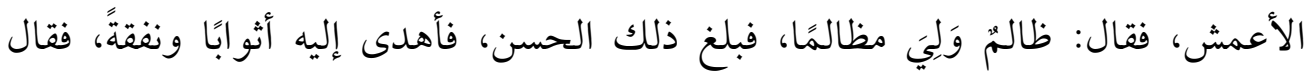
الأعمش: مثل هذا يصلح أن يُولَّى علينا، يرحمُ صغيرَنا، ويوقِّرُ كبيرَنا، ويعود على فقلى فقيرنا،

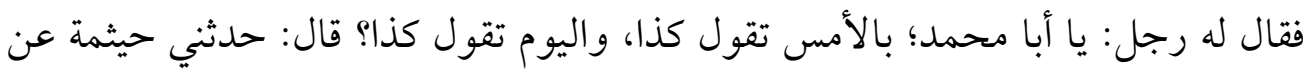

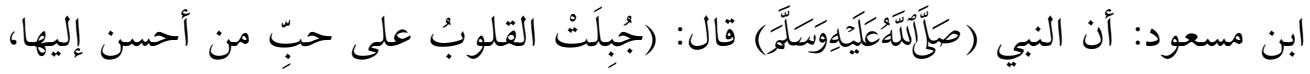
وبغض من أساء إليها) والأصح: وقفه على ابن مسعود. النجم الوهاج في شرح المنهاج (or $7 / 0$ )

البيتان لدعبل. ينظر: الدر الفريد وبيت القصيد، لمحمد بن أيدمر المستعصمي

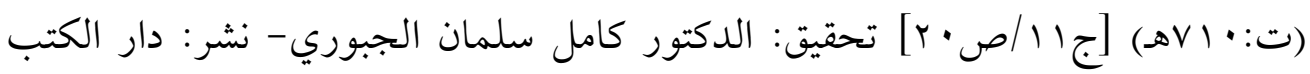

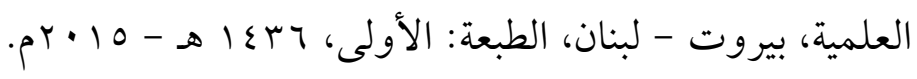

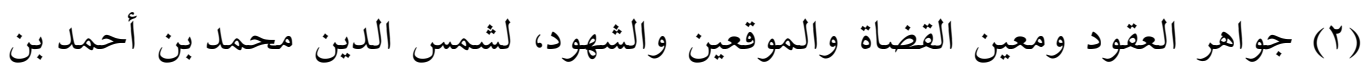

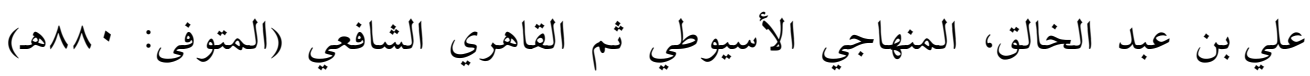

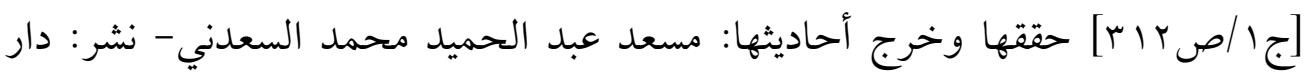

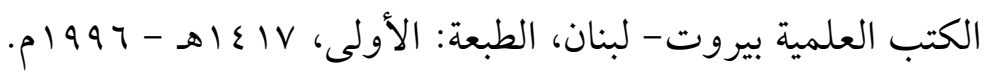




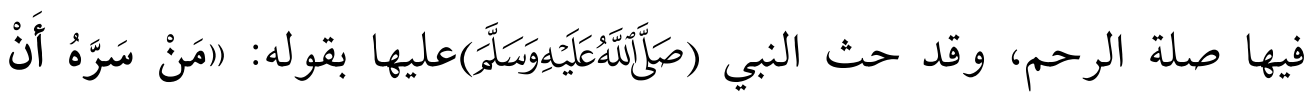

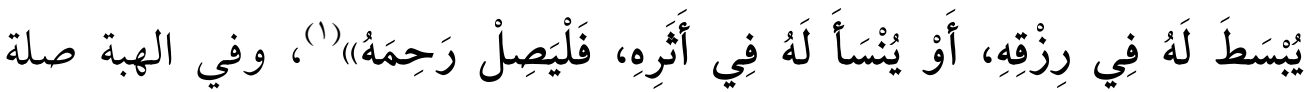
الرحمث (r)

و الهبة، والهدية، وصدقة التطوع: حكمها واحد: وكل لفظة من هذه

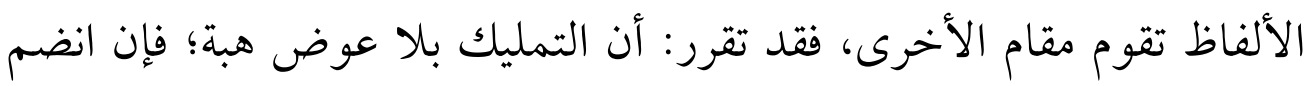

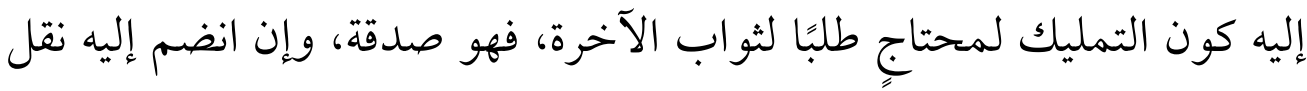

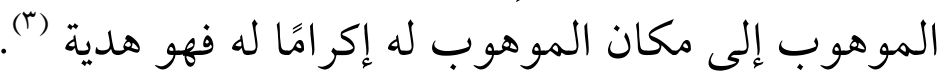
ولا شك أن هناك فرقًا بين عقدي الهبة والوصية؛ فالهبة تمليك للحال،

(1) متفق عليه، واللفظ للبخاري. الجامع المسند الصحيح المختصر من أمور رسول الله

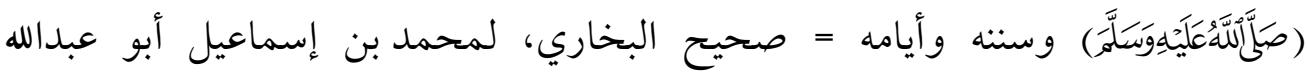

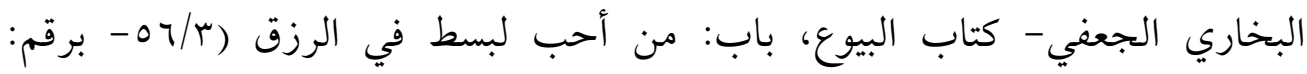

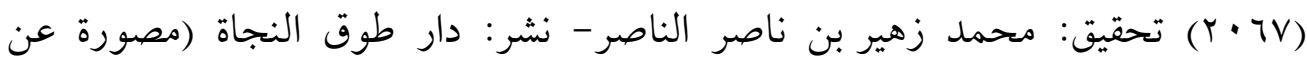

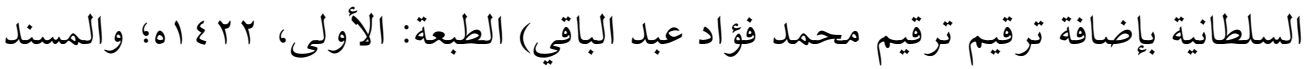

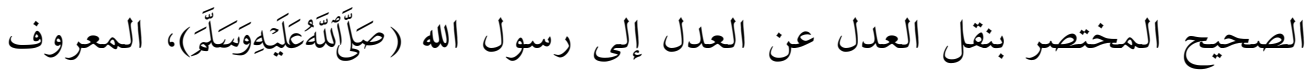

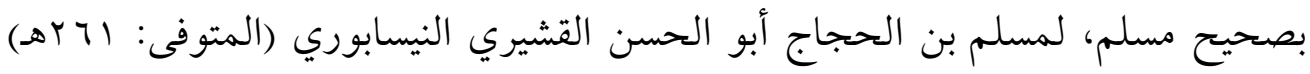

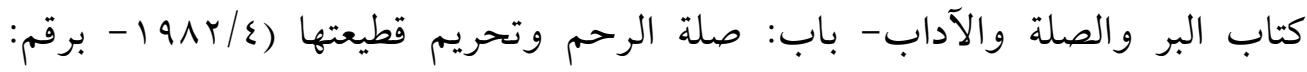
(roOV)

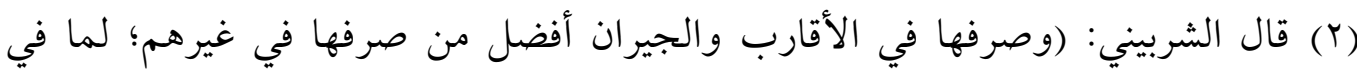

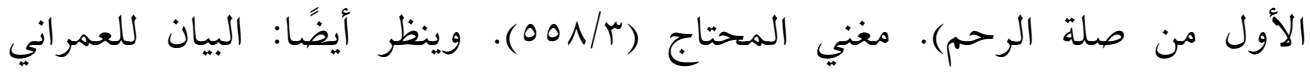

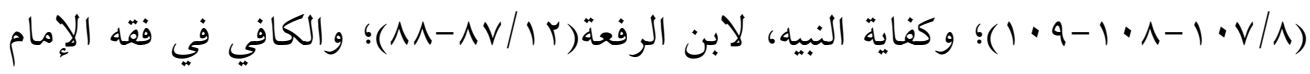

$$
\begin{aligned}
& \text { أحمد (roq/r) } \\
& \text { (r) جواهر العقود (r/r/I). }
\end{aligned}
$$


بخلاف الوصية التي هي: تبرعٌ بحقٍّ مضاف إلى ما بعد الموت(1)، ولذا سميت وصية؛ لأن الميت يصل بها ما كان في حياته بما بعد مماته (r). والهبة أفضل من الوصية؛ لما روى أبو هريرة قال: جاء رجل إلى النبي

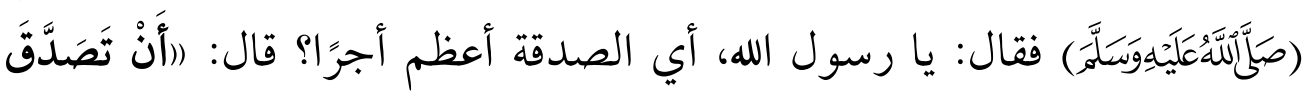

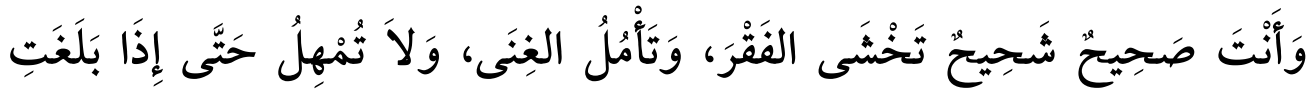

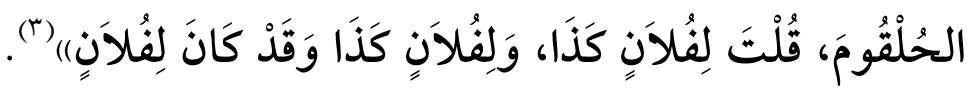

قال ابن بطال: (فيه: أن أعمال البر كلما صعبت كان أجرها أعظم؛ لأن الصحيح الشحيح إذا خشي الفقر، وأمل الغنى، صعبت عليه النفقة، وسوَّل له

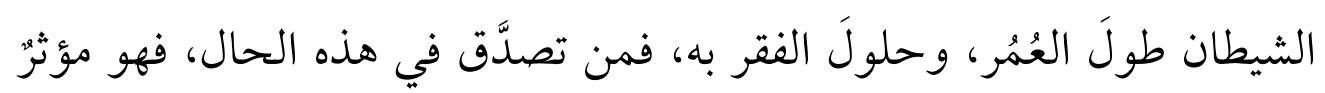
لثواب الله على هوى نفسه، وأما إذا تصدَّق عند خروج نفسه، فيُخشَى عليه الضرار بميراثه، والجور في فعله، ولذلك قال ميمون بن مهران حين قيل له:

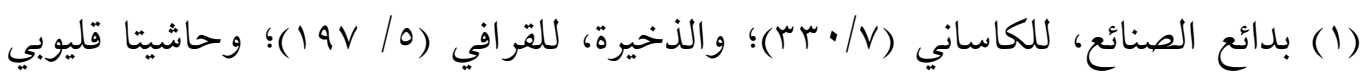

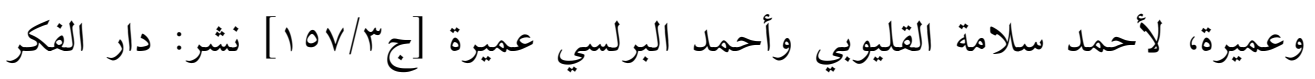

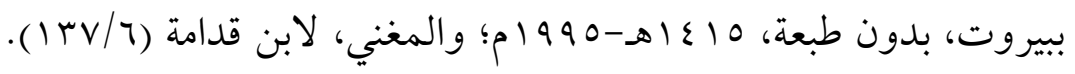

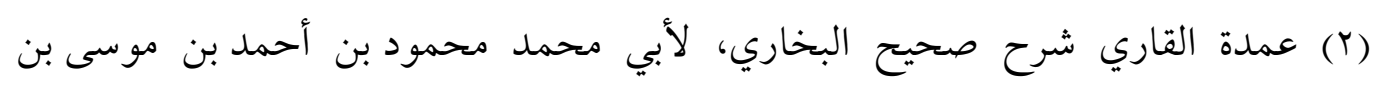

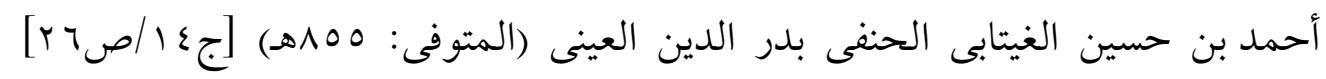
نشر: دار إحياء التراث العربي - بيروت.

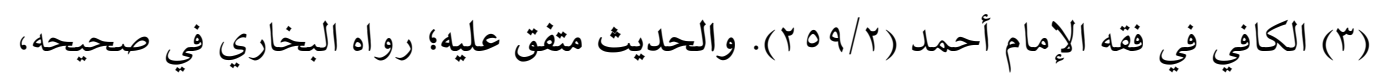

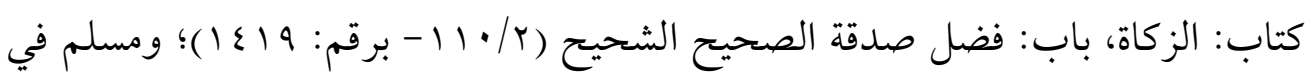

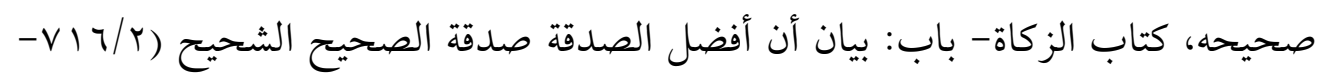

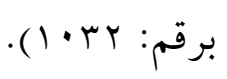


إن رقية امرأة هشام ماتت، وأعتقت كل مملوك لها، فقال ميمون: يعصون الله

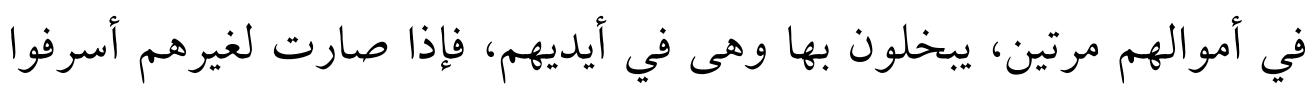
فيها) (1)

(وقال قتادة: يا ابن آدم، اتق الله ولا تجمع إساءتين في مالك؛ إساءة في الحياة الدنيا، وإساءة عند الموت، انظر قرابتك الذين يحتاجون ولا يرثونك،

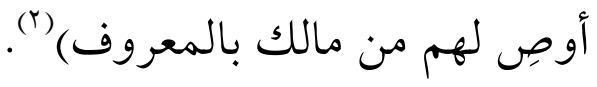

وقد كانت الوصية للأقارب قبل نزول آية المواريث فرضًا، فلما نزلت

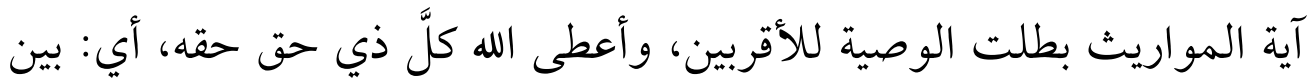
نصيب كل وارث من الميراث، فلا وصية بعدها لوارث، أي: لا تجوز له له

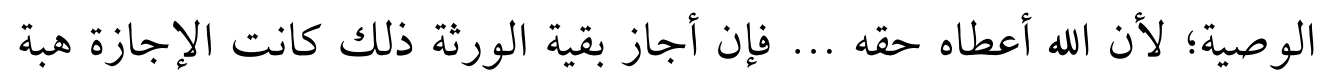
مبتدأة، يُعتبر فيها ما يعتبر في الهبة (").

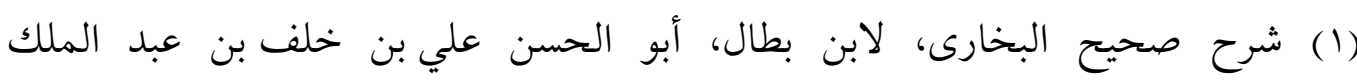

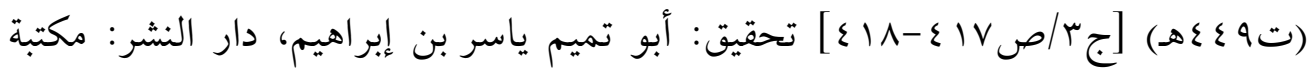

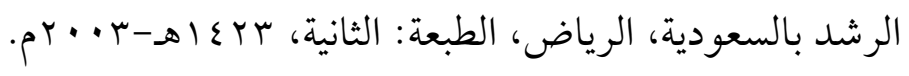

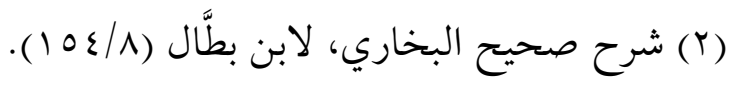

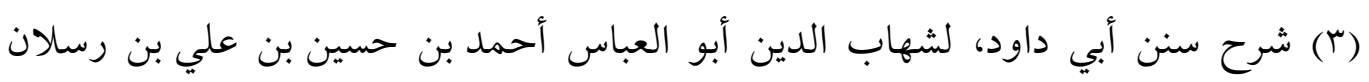

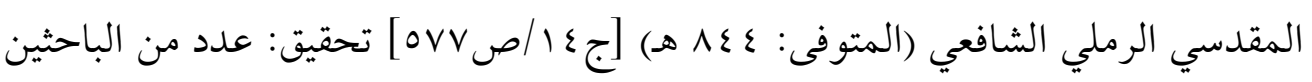

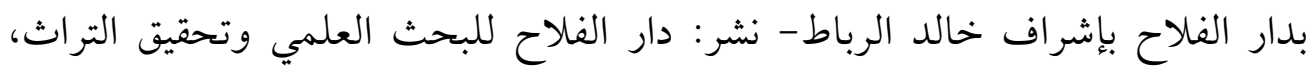

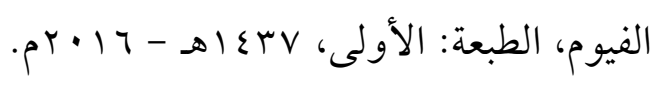




\section{المبحث الثاني}

تفضيل الو الد بعضَ أولاده بـالهبة لسبب يقتضي التفضيل

أولا : تحرير محل النزاع:

اتفق الفقهاء على أنه ينبغي للو الد أن يسويَ بين أولاده في العطية، لقول

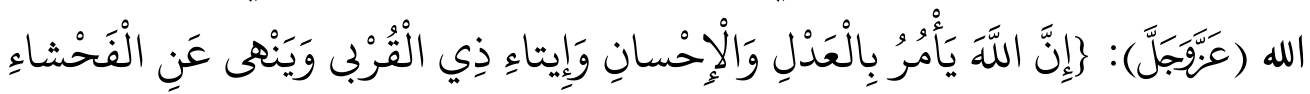

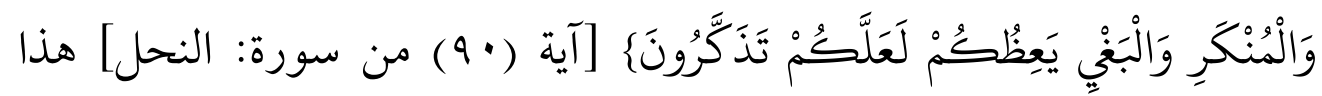

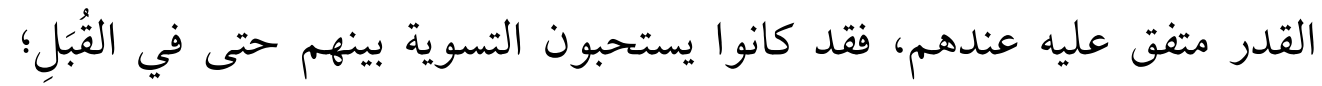

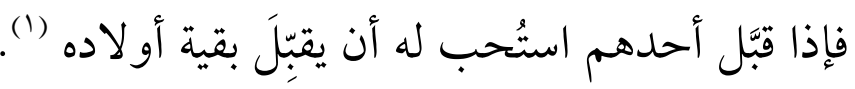

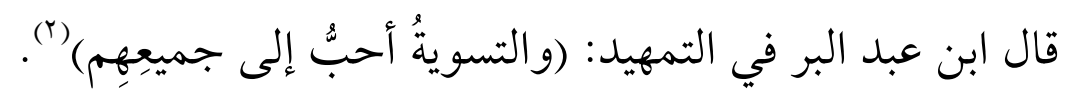

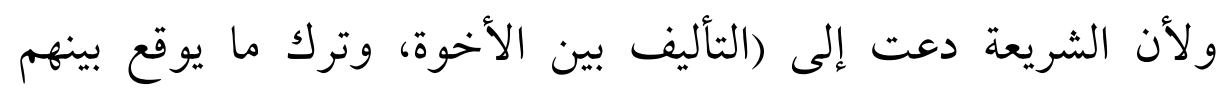
الشحناء، ويورث العقوق للآباء)(")

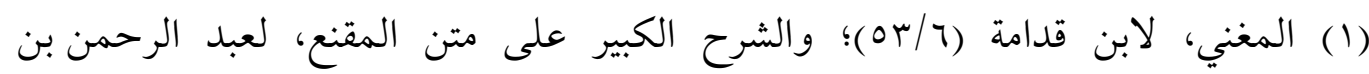

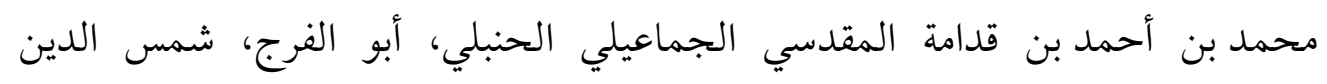

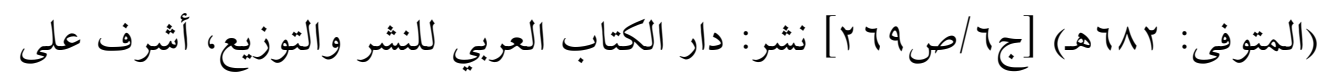

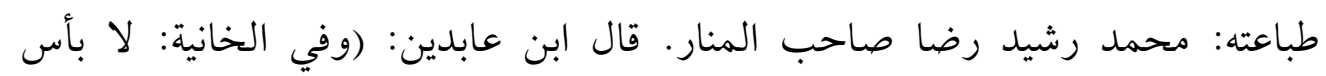

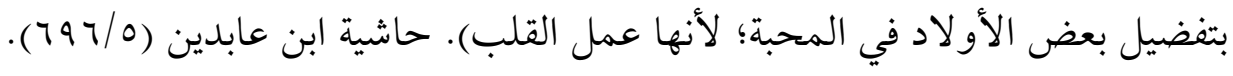

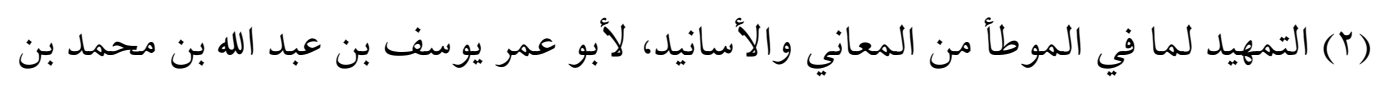

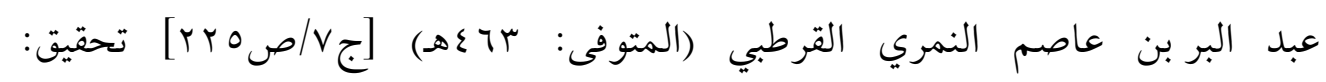

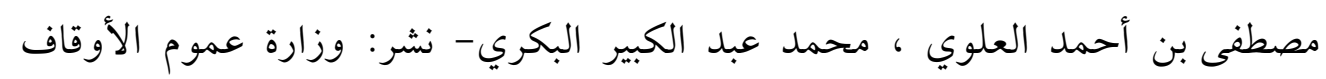

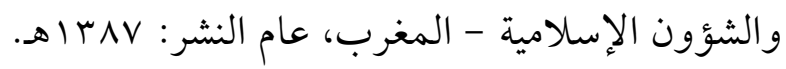

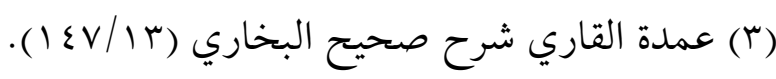


وكذا لا خلاف في أن الو الد إذا قسَّم ماله في حياته بين أولاده قسمة المواريث، أن تلك القسمة صحيحة؛ اقتداءً بقسمة الله تعالى، وقياسًا لحالة الحياة على حال الموت، قال عطاء: (فما كانوا يقسمون إلا على كتاب الله تعالى) (1)

ولا خلاف بينهم كذلك في أن الوالدَ إذا فضَّل أحدَ أولادِه بعطيةٍ، ورضي بقية الأبناء رضًا غير مشوب بإكراه أو حياء، كأن كان طلب التفضيل منهم؛ أن ذلك جائز لا حرج فيه؛ فالمنع لأجلهم؛ فإذا أسقطو حقهم زال الحرج، (والقاعدة أن ذا الحق إذ أسقط حقه سقط) (r).

لكنهم اختلفوا في الحكم التكليفي للتفضيل، بين مانع ومجوز، والمانعون ما بين قائل بالحرمة، و آخر بالكر اهة. وفوَّق المانعون بين حالين: الأول: إذا كان التفضيل لعلة رآها الوالد في الولد تقتضي تفضيله، كحاجة، أو مرض ...إلخ. الثاني: إذا كان التفضيل لغير علة.

(1) الدلائل والإشارات على أخصر المختصرات لمحمد بن بدر الدين البلباني الحنبلي

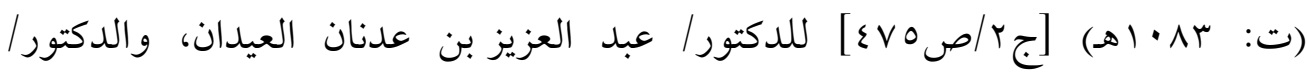

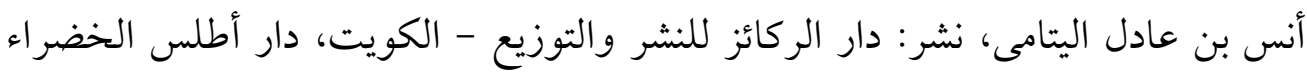

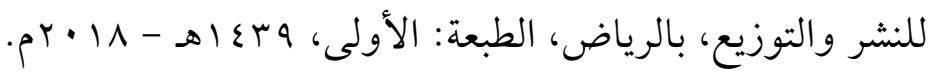
(r) المتواري علي تراجم أبواب البخاري، لأحمد بن محمد بن منصور بن القاسم بن مختار

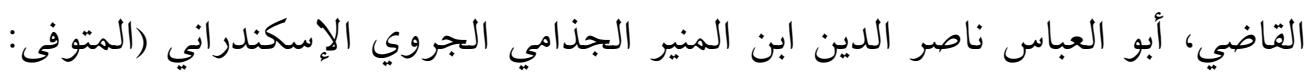

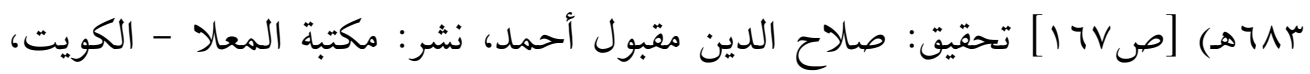
بدون طبعة، وبدون تاريخ. 


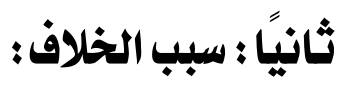

سبب الخلاف في هذه المسألة: معارضة القياس للفظ النهي الوارد؛

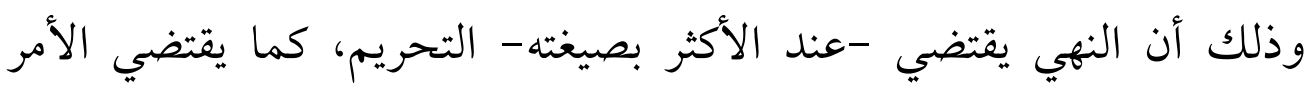
الوجوب.

فمن ذهب إلى الجمع بين السماع والقياس؛ حمل الحديث [الوارد

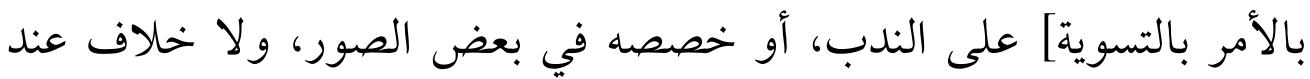

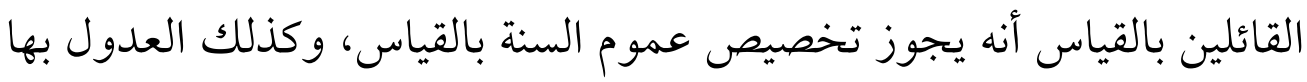

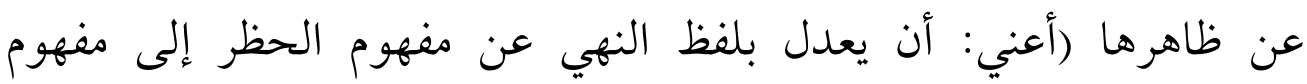

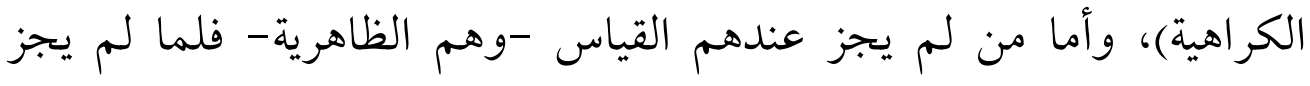
عندهم القياس في الشرع، اعتمدوا ظاهر الحديث، وقالوا بتحريم التهرئ التفضيل في الهبة (1)

أما تفضيل الوالد بعضَ أولاده بالهبة لمعنى يقتضي تخصيصه، مثل

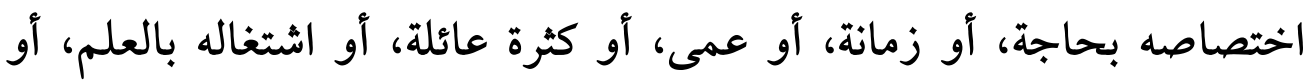

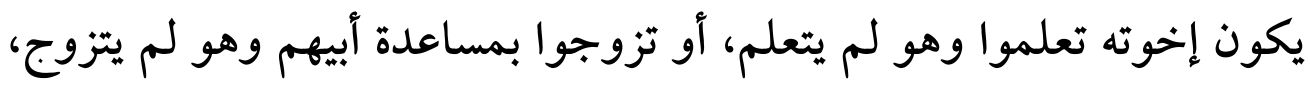

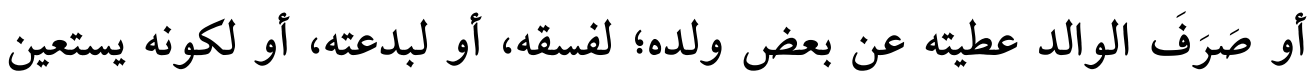

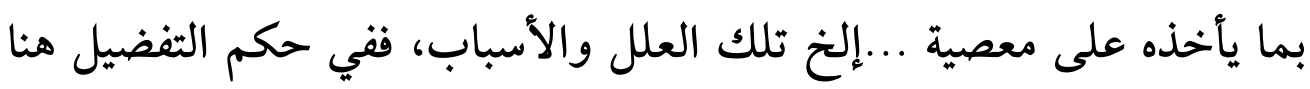
قولان:

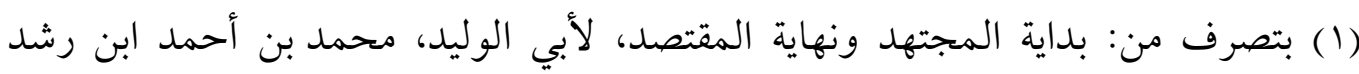

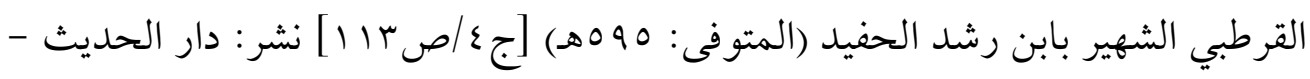

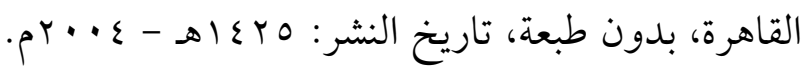


القول الأول: الجواز. وهذا القول هو ما عليه متأخرو الحنفية (1)، وهو

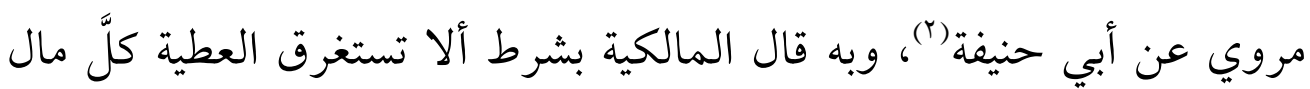

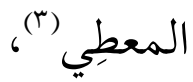

قال الكاساني: (....وأما على قول المتأخرين منهم لا بأس أن يعطي المتأدبين

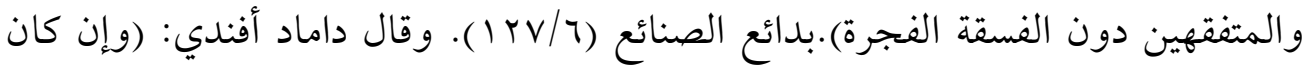

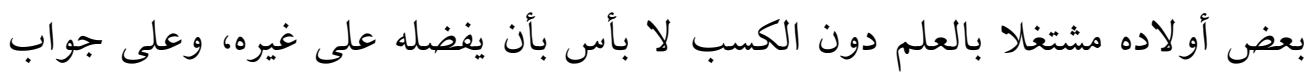

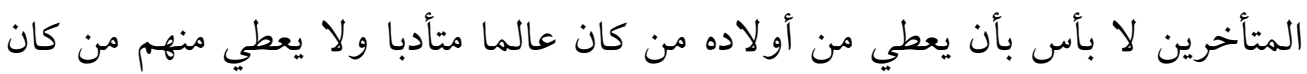

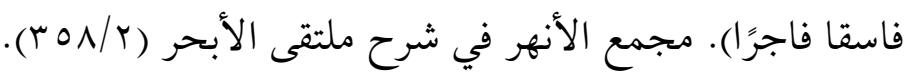

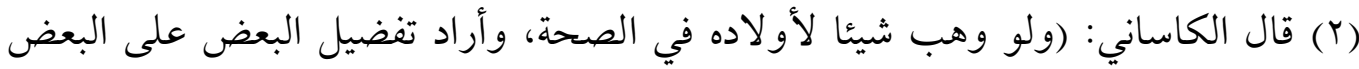

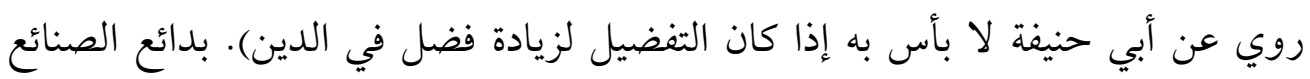
. ( $\varepsilon \varepsilon \varepsilon / \varepsilon)$

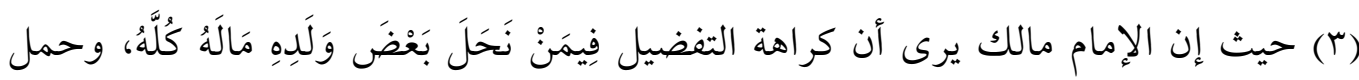

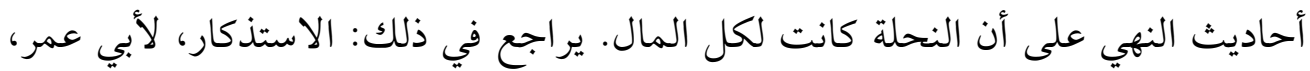

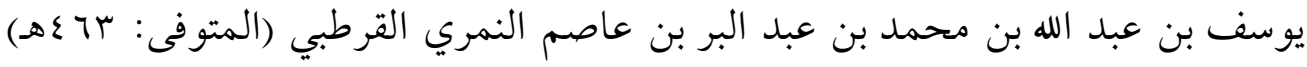

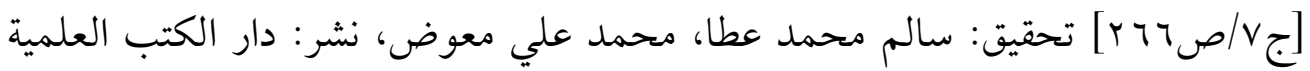

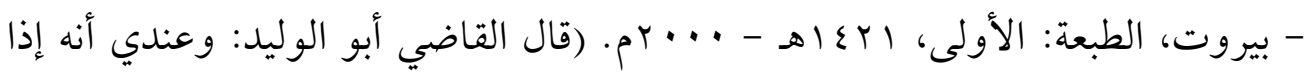

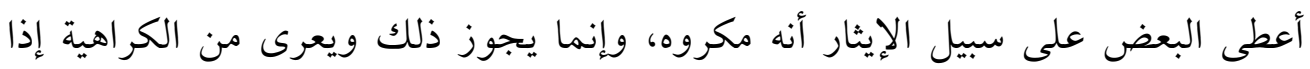

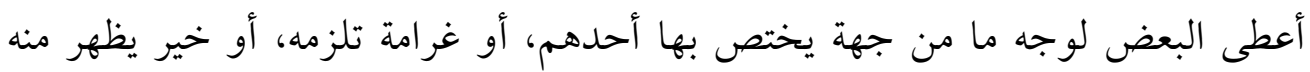

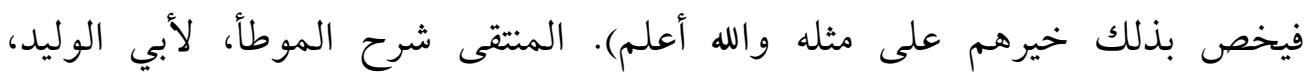

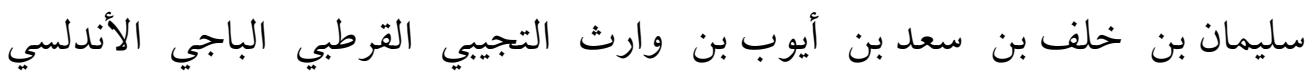

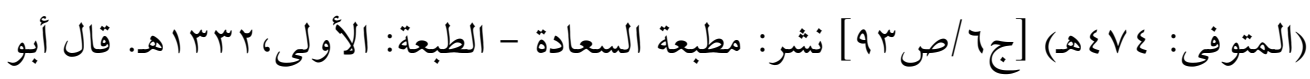

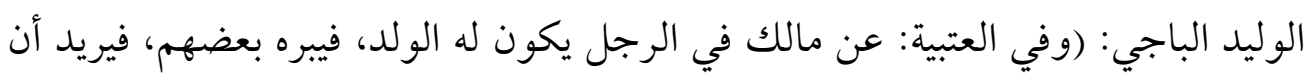

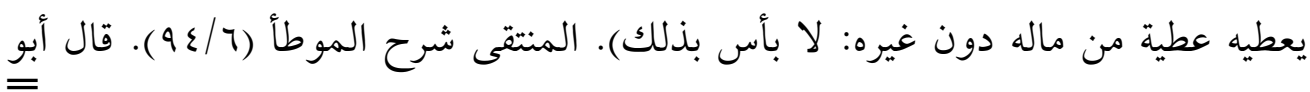


وبه قال الشافعية(1)، وإحدى الروايتين عن الإمام أحمد(r)، رجحها ابن قدامة،

الوليد الباجي: (ويعرى من الكراهية إذا أعطى البعض لوجه ما من جهة يختص بها

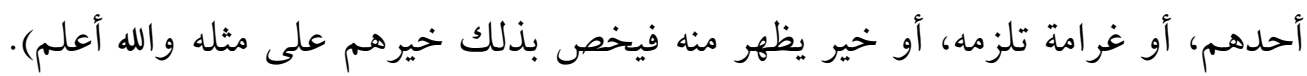

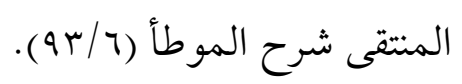

(1) قال ابن الملقن: (نعم لو تفاوت أولاده في الحاجة: فليس فيه المحذور السالف، كما

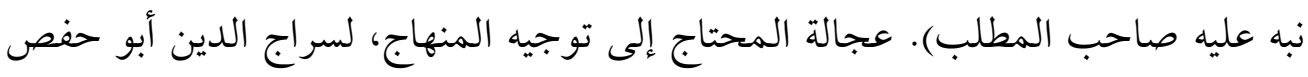
عمر بن علي بن أحمد المعروف بـ (ابن النحوي)" والمشهور بـ (ابن الملقن)" (المتوفى:

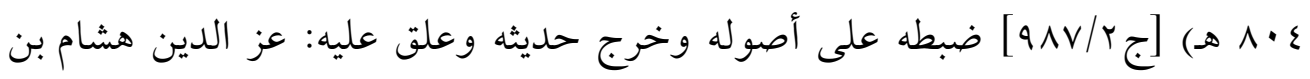

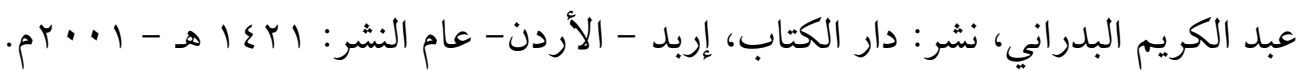
وقال الخطيب الشربيني: (ويستثنى العاق والفاسق إذا علم أنه يصرفه في المعاصي، فلا إلا

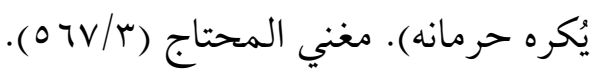

وقال ابن حجر: (لو علم من المحروم الرضا وظن عقوق غيره لفقره ورقة دينه، لم يسن

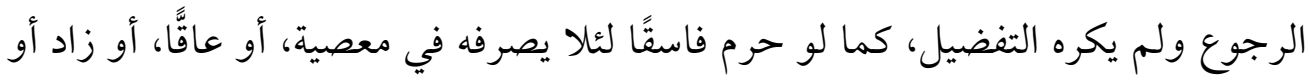

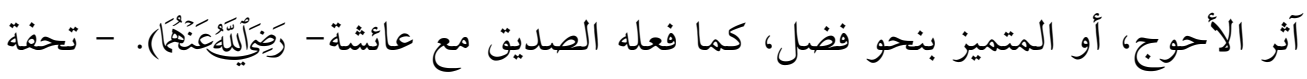

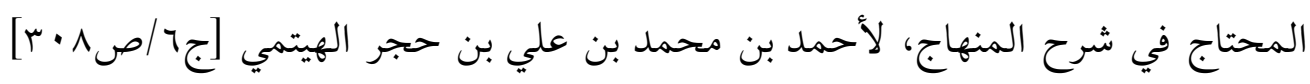

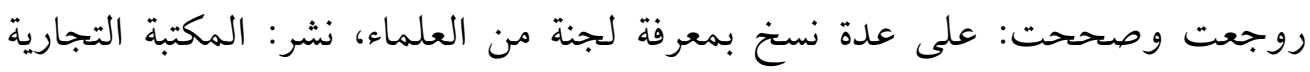

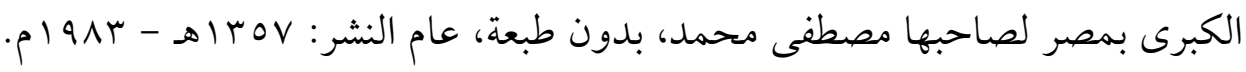

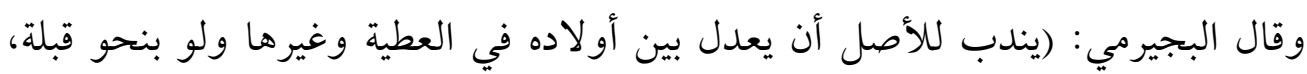

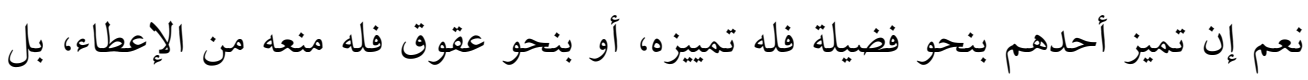

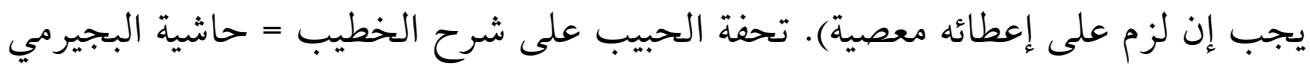

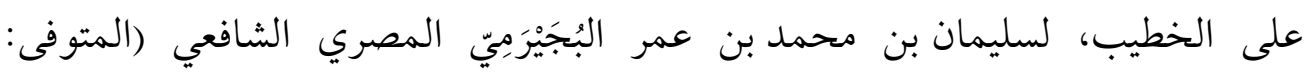

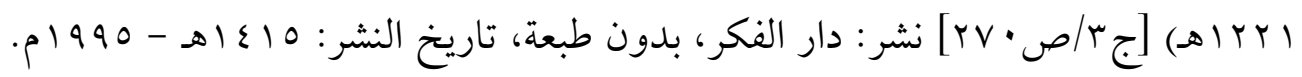
(r) فقد ورد عنه ما يدل على جواز ذلك؛ لقوله (رحمه الله) في تخصيص بعضهم بالوقف: 
وذكر أنها الأولَى (1)، قال الزركشي: وهذا اختيار أبي محمد(r)، ونسبه المروزي إلى ابن المبارك ().

القول الثاني: المنع، وتجب التسوية في العطية. وهو قول المتقدمين من أصحاب أبي حنيفة()) ويحتمله ظاهر لفظ الإمام أحمد؛ وهو ظاهر كلام

لا بأس به إذا كان لحاجة، وأكرهه إذا كان على سبيل الأثرة، والعطية في معناه. المغني،

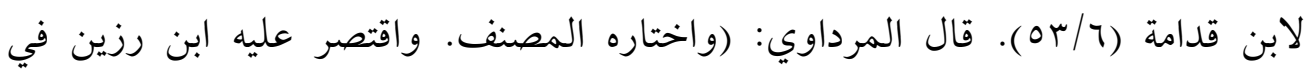
شرحه......وقطع به الناظم. وقدمه في الفائق. وقال: هو ظاهر كلامه. قلت (المرداوي): قد روي عن الإمام أحمد (رحمه الله) ما يدل على ذلك؛ فإِه قإنه قال في

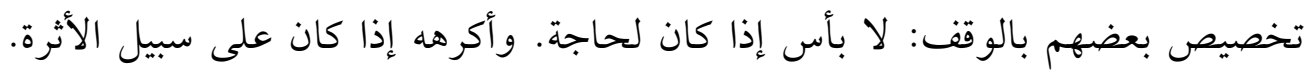

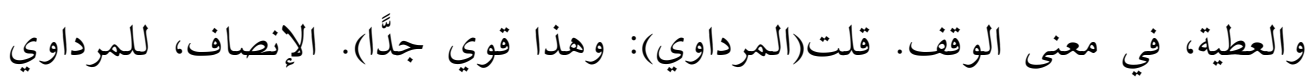
. $(7 \varepsilon-7 r / 1 V)$

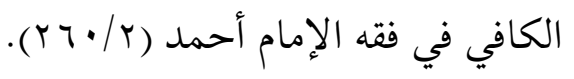

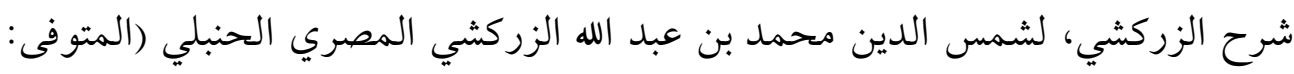

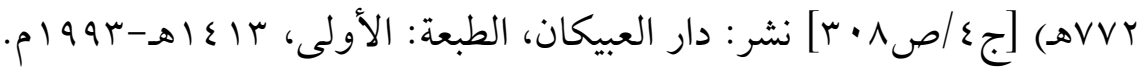
(r) قال المروزي: (ويحكى عن ابن المبارك في حديث عائشة: لا بأس بأن يفضل بعض الرض ولده في العطية عند نائبة تنوبه، وكلك إذا نابت الولد الآخر مثل تلكئ الك النائبة أن يعطيه مثل ذلك ولا يعطيه وهو يريد بعطيته التفضيل له على غيره. قال: وعلى هذا الوجه حديث أبي بكر في نحله عائشة. وكان إسحاق يذهب إلى هذا) - اختلاف الفقهاء، لأبي

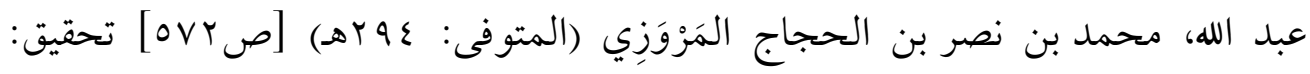

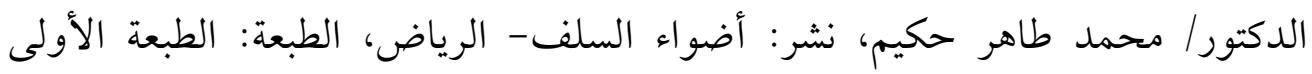

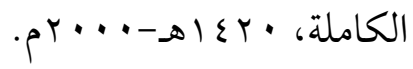
قال الكاساني: (ولو نحل بعضًا وحرم بعضًا جاز من طريق الحكم؛ لأنه تصرف في 
الخِرَقي، بل ذكر الزركشي أن الإمام أحمد نص عليه في رواية يوسف ابن موسى، قال: وهو ظاهر كلام الأكثرين (')، وبه قال الظاهرية (r).

\section{الأدلة:}

\section{استدل أصحاب القول الأول، القائلون بجواز التفضيل لعلة، بما يلي:}

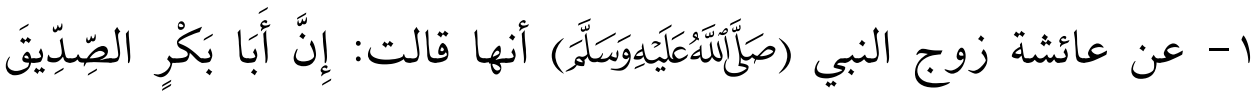

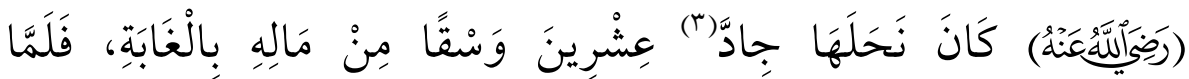

خالص ملكه لا حق لأحد فيه، إلا أنه لا يكون عدلًا، سواء كان المحروم فقيها تقيَّا أو

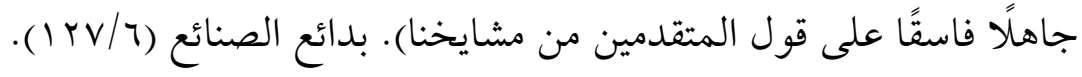
(1) المغني، لابن قدامة (7/7ه). قال المرداوي: (ظاهر كلام المصنف: مشروعية التسوية

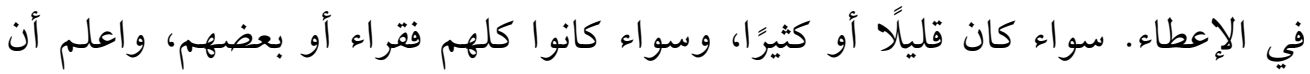

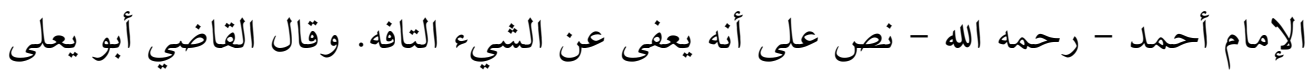

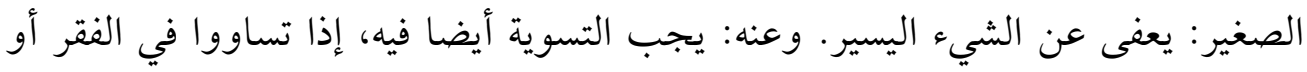

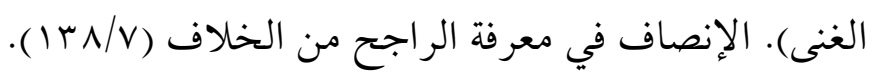

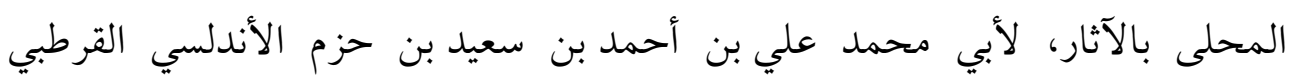

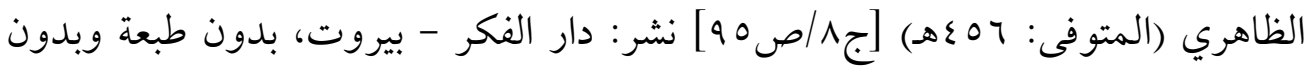

تاريخ.

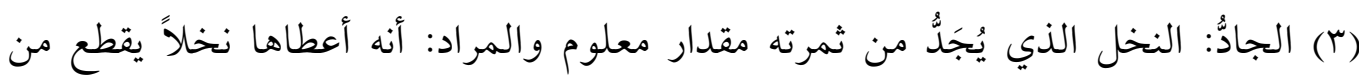

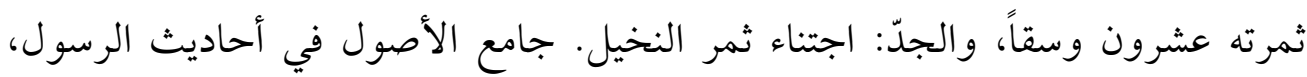

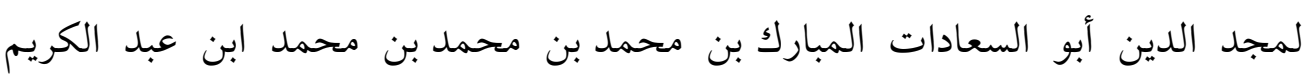

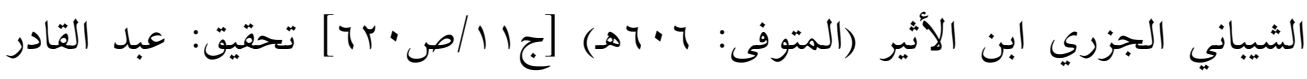
الأرنؤوط- التمة تحقيق بشير عيون، نشر : مكتبة الحلواني - مطبعة الملاح - مكتبة دار 


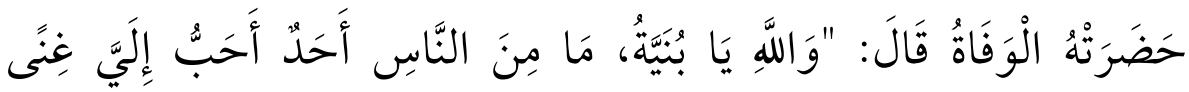

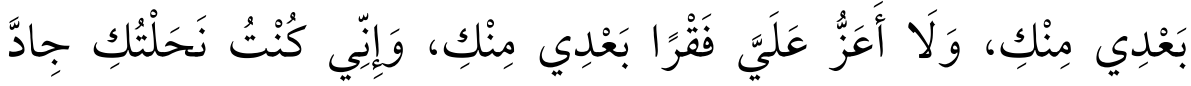

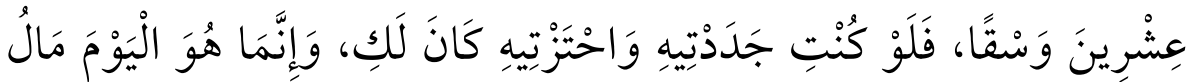

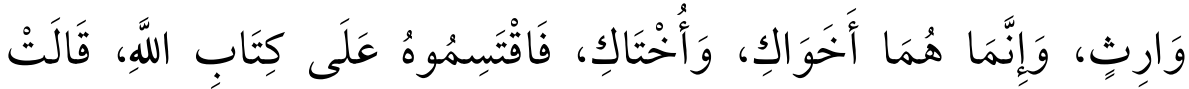

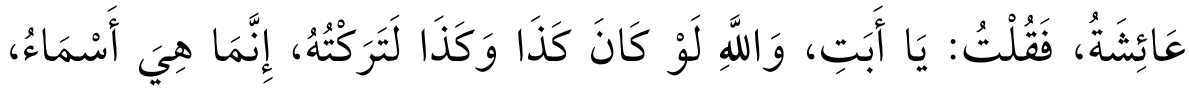

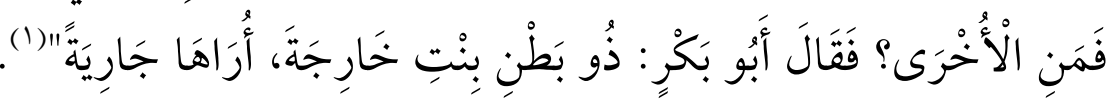

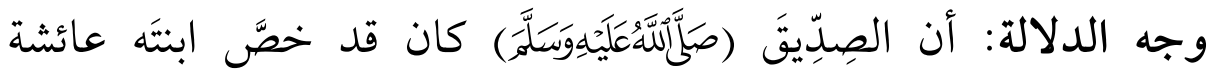

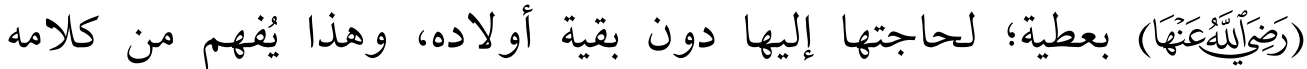

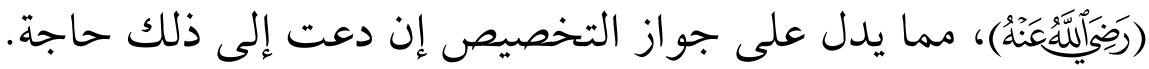
ץ- ويمكن أن يُستدلَّ لهذا المذهب بما رواه البيهقي عن عبد الرحمن الأنصاري أنه انطلق هو وابن عمر حتى أتوا رجلاً من الأنصار،

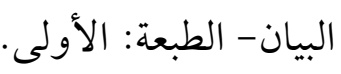

صحيح: رواه: مالك في الموطأ، وعبد الرزاق في المصنف، والبيهقي في الكبرى،

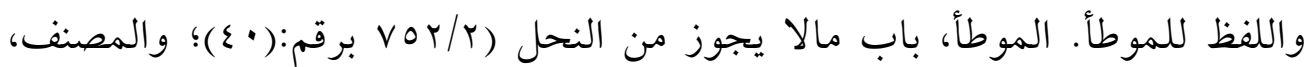

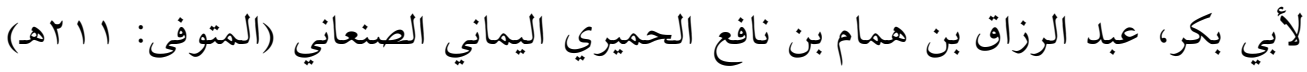

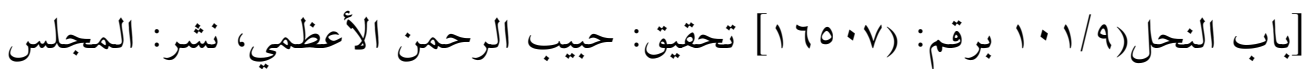

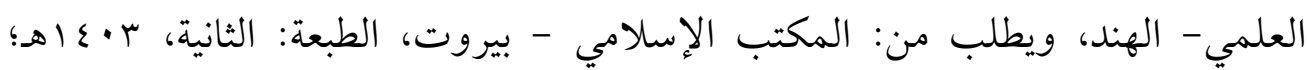

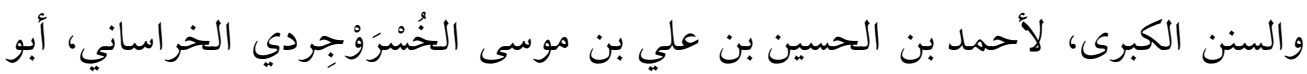

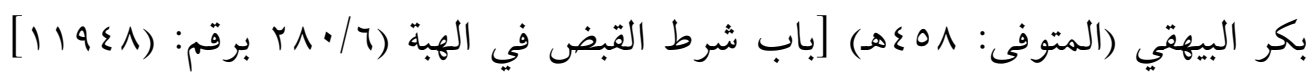

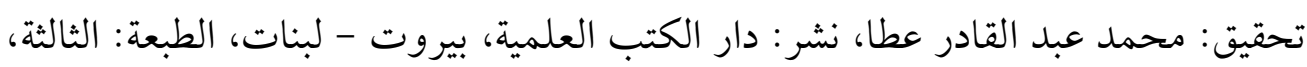

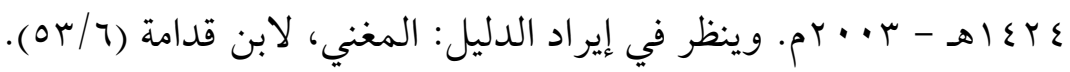


فساوموه بأرضٍ له، فاشتراها منه، فأتاه رجلٌ، فقال: إني رأيت أنك أنك

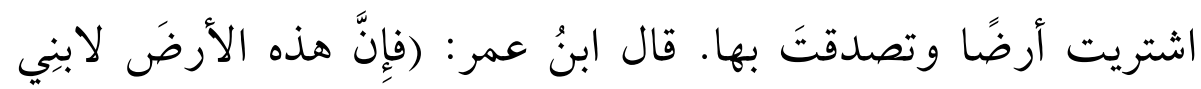

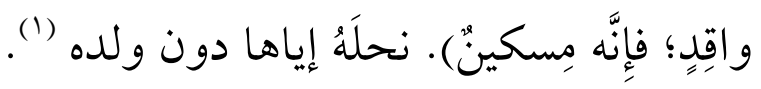

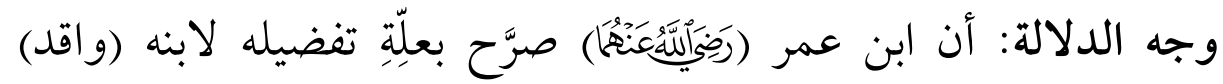
بهذه الأرض، فقد فضَّله بهذه العطية لحاجته ومسكنته، مما يدل على الجواز. ب- و لأن بعضهم اختُص بمعنَى يقتضي العطية، فجاز أن يُختََّّ بها، كما

$$
\text { لو اختَُّّ بالقرابة('). }
$$

\section{واستدل أصحاب القول الثاني، القائلون بمنع الثفضيل لعلة، بما يلي:}

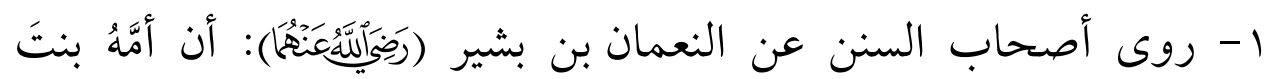

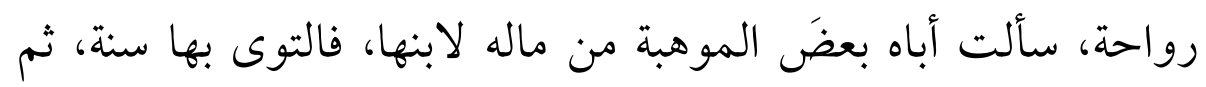

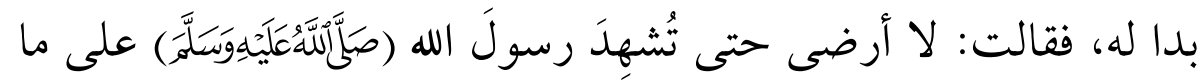
وهبتَ لابني، فأخذ أبي بيدي - وأنا يومئذ غلام- فأتى رسول ألهات الله

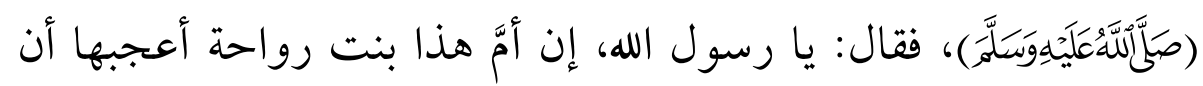

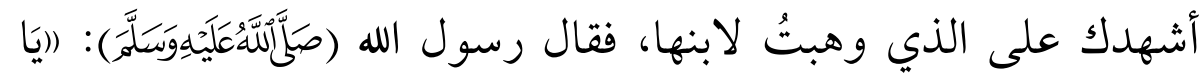

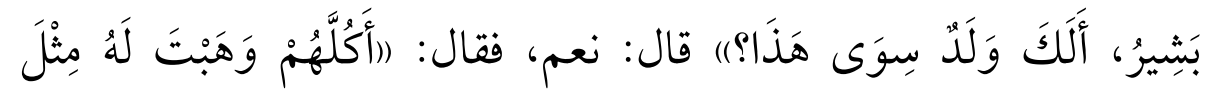

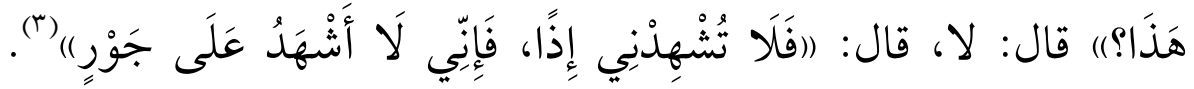

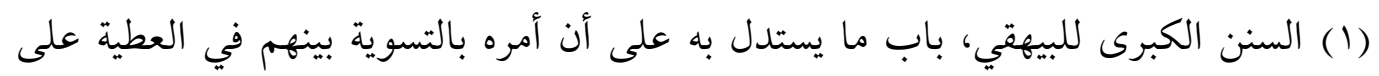

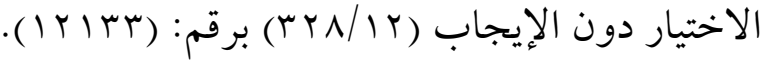

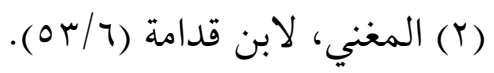

(r) متفق عليه: واللفظ لمسلم: صحيح البخاري، باب الهبة للولد، وإذا أعطى بعض ولده 
وهو حديث متفق على صحته، وإن كان قد اختلف في ألفاظه (1).

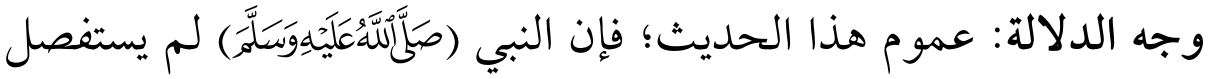
بشيرًا في عطيته، ولم يسأله عن سبب العطية، مما يدل على عموم الحكم في كزّ

شيئا لم يجز، حتى يعدل بينهم ويعطي الآخرين مثله، ولا يشهد عليه بلفظ: (افَاتَُّوا اللَّه

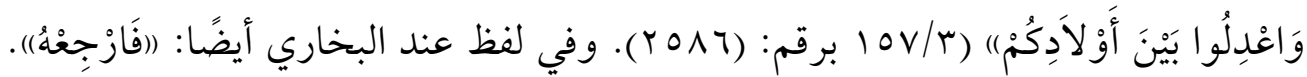

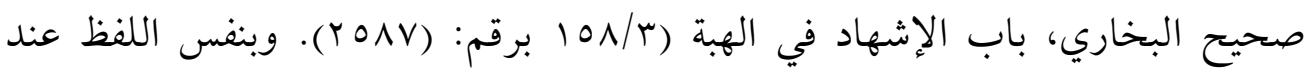

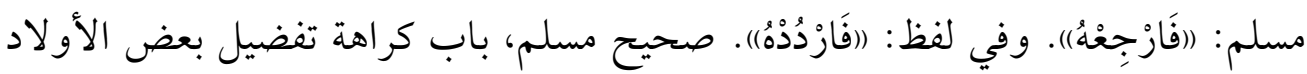

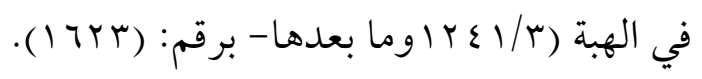

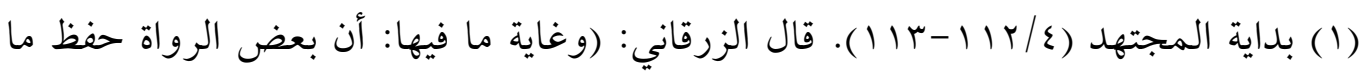

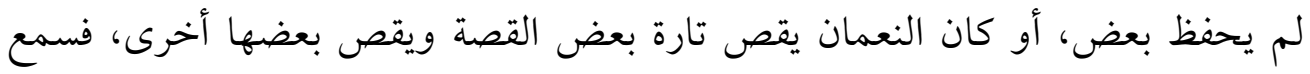

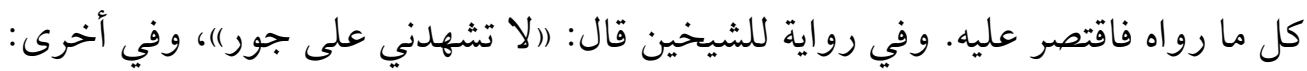

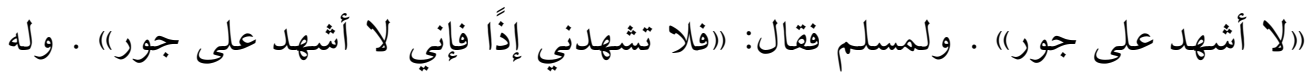
أيضا: (أشهد على هذا غيري) . وفي حديث جابر: ((فليس يصلح هذا، وإني لا أشهد إلا إنا

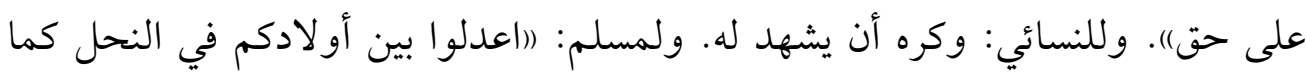

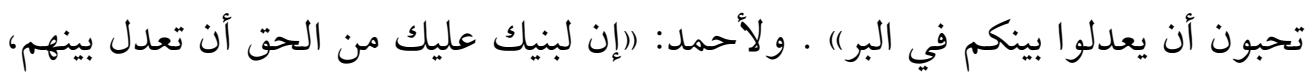

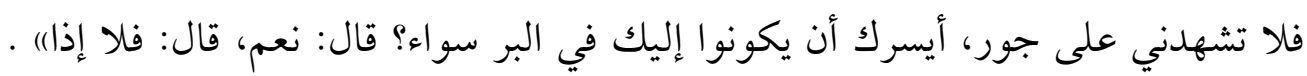

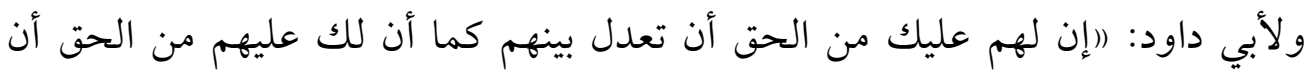

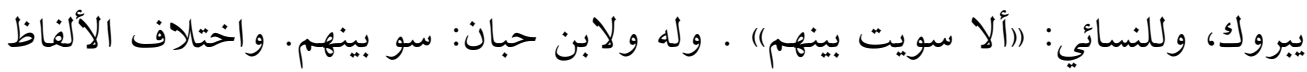

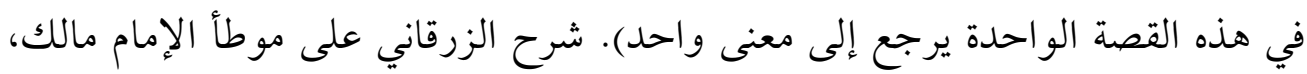

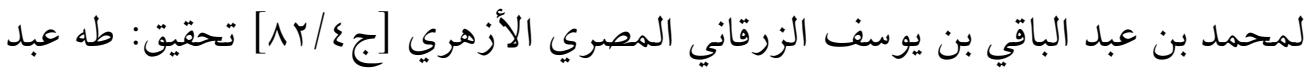

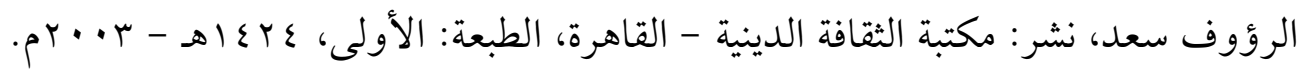




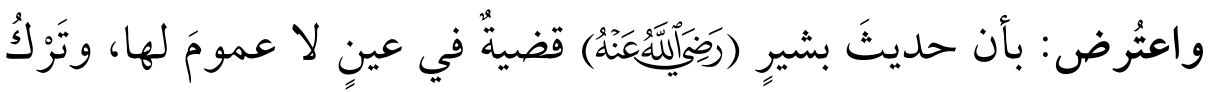

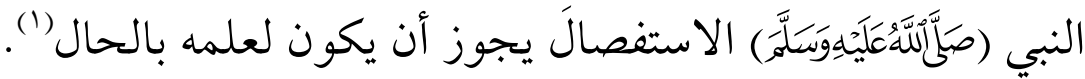

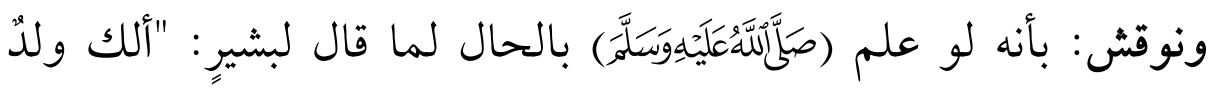

أجيب: بأنه يحتمل أن يكون السؤال هاهنا لبيان العلة، كما قال

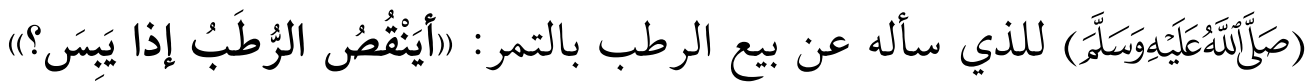

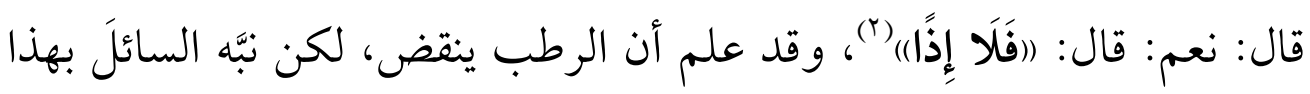

(1) المغني، لابن قدامة (7/7ه).

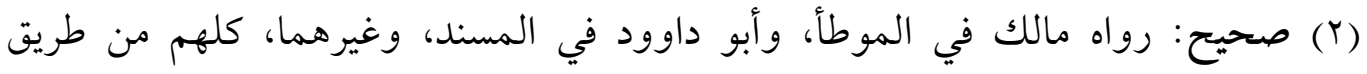

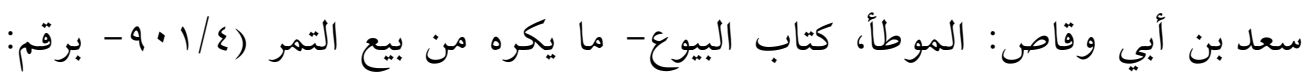

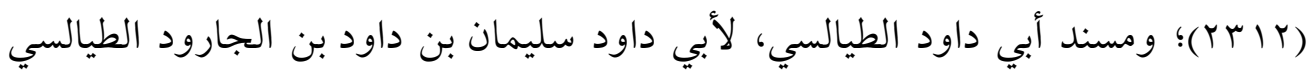

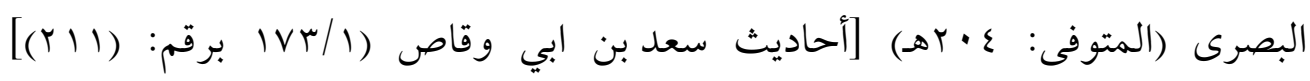

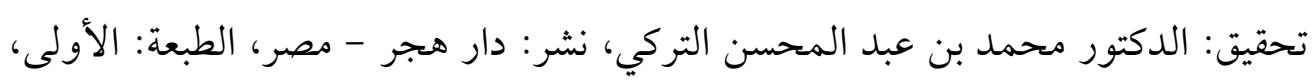

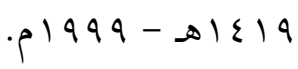
قال الترمذي: (هذا حديث حسن صحيح، والعمل على هذا عندا عند أهل العلم، وهو قول

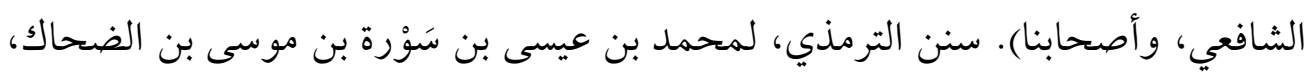

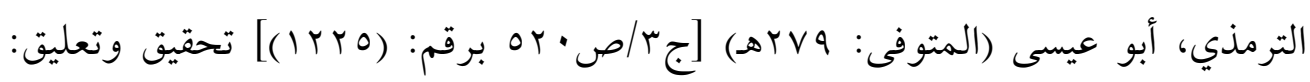

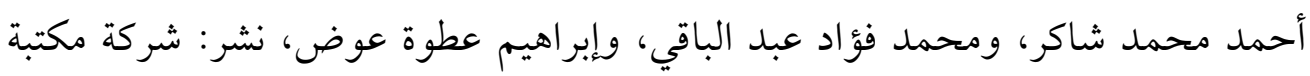

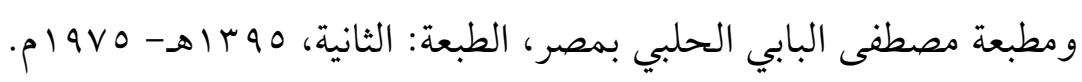

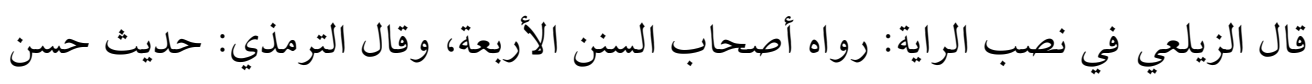

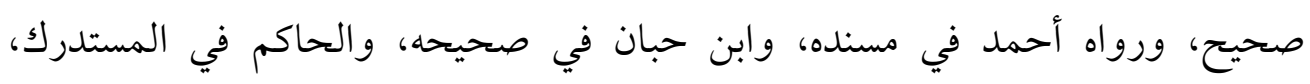

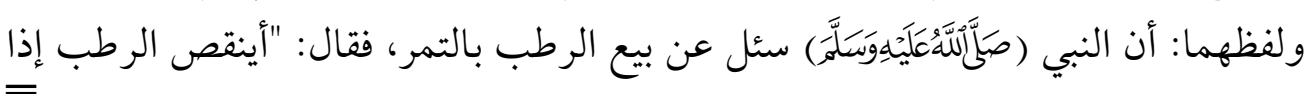


جف؟ قالوا: نعم، قال: "فلا إذن"، انتهى. قال الحاكم: هذا حديث صحيح لإجماع أئمة

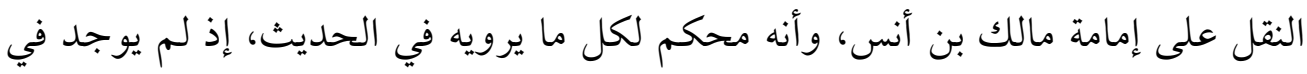

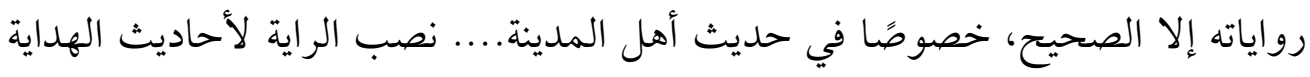

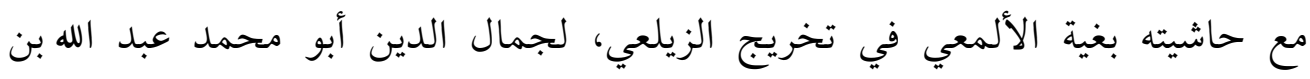

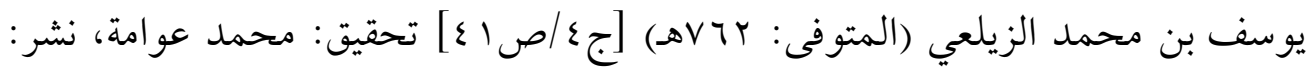

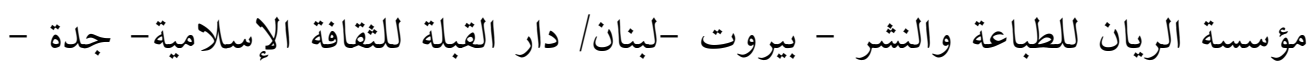

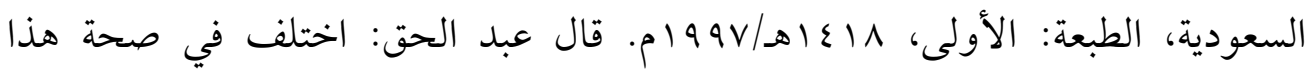
الحديث، ويقال: إن زيدا أبا عياش هذا مجهول، وتبع في ذلك أبا محمد بن حزم فإنها هانه قال في (الرسالة التي له في إبطال القياس) : هذا حديث لا يصح لجهالة أبي عياش.

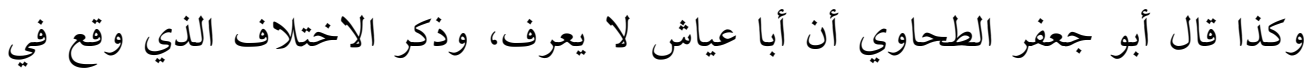

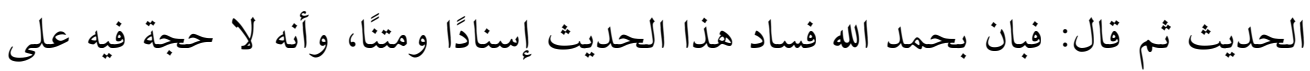
من خالفه من أبي حنيفة ومن تابعه. قلت [ابن الملقن]: ومدار تضعيف من ضعفه على على جهالة (أبي عياش)، وأول من رددَّه بذلك أبو حنيفة. قال: هو مجهول؛ لما سئل عن هذه المسألة عند دخوله بغداد، وقال

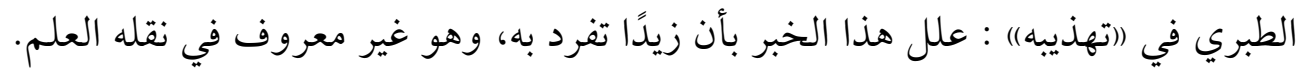
والجواب عن ذلك: أن (أبا عياش) ليس بمجهول بل هو هو معروف، رواه باه عنه مالك في

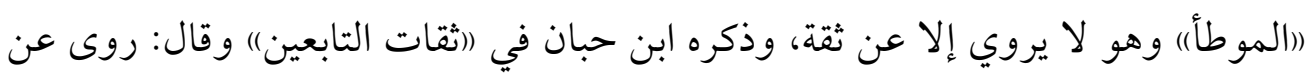

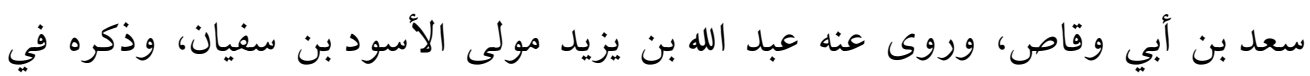

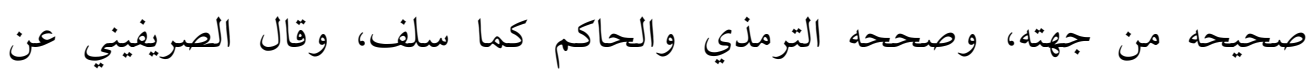

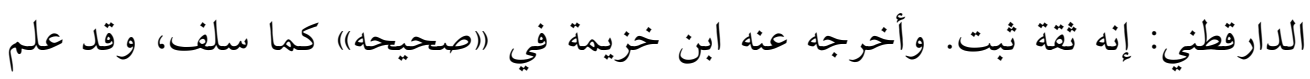

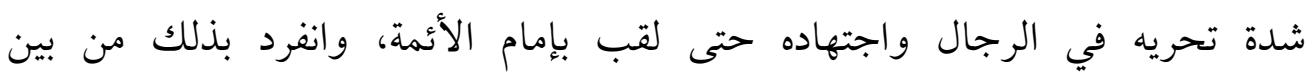

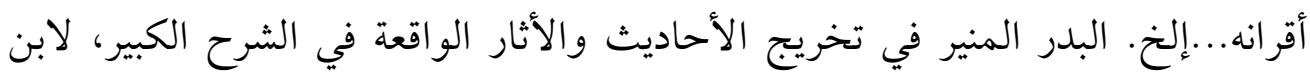
الملقن سراج الدين أبو حفص عمر بن علي بن أحمد الشافعي المصري (المتوفى: 
على علة المنع من البيع، كذا هاهنا (1).

r- ولأنهم سواء بالإرث، فكذلك في عطيته في حياته (r).

الرأي المختار، وعلة اختياره:

يرى الباحث رجحان قول المجيزين للتفضيل؛ لأن التفضيل هنا له مسوغ مقبول، وسبب يقتضيه، والهبة في هذه الحالة لا حرجَ فيها؛ إذ لا يخلو

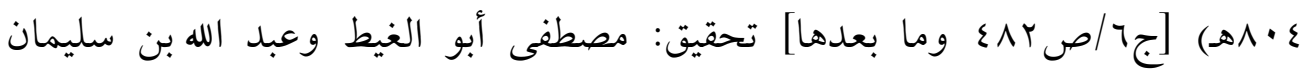

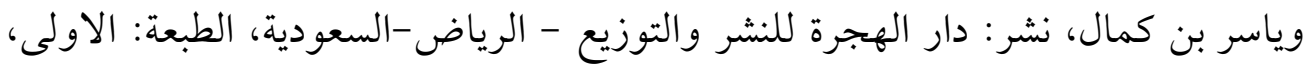

$$
\text { . }
$$

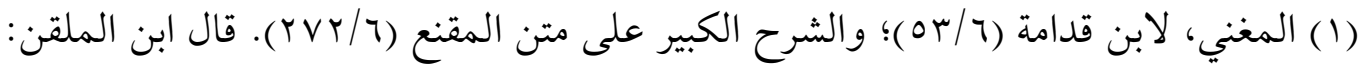

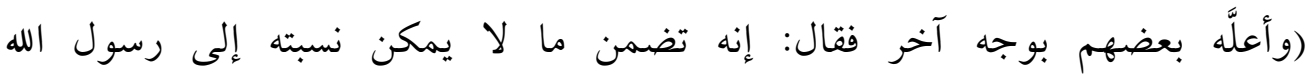

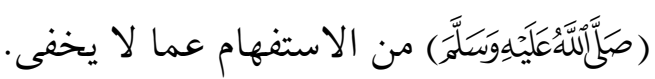
وهذا عجيب من قائله، فالحديث لفظه لفظ استفهام، ومعناه التقرير والتنبيه، لينبه على ثلاثة:

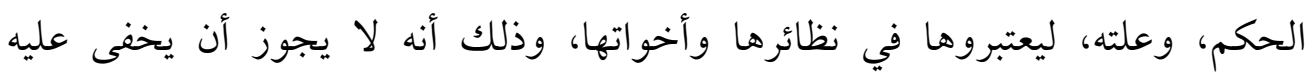

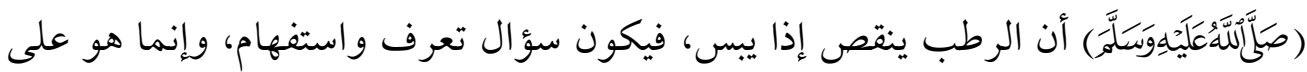
الوجه الذي ذكرته وهذا كقول جرير:

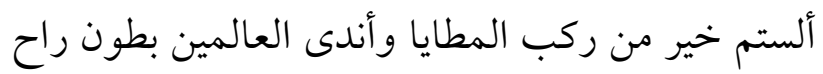
ولو كان استفهاما لم يكن فيه ملح، وإنما معناه: أنتم خير من ركب رلح المطايا، وهذا جواب الخطابي. والاستفهام بمعنى الثقرير كثير، موجود في القر آن العظيم في قوله تعالى : (وَمَا تِلْكَكَ بِيَمِينكَ

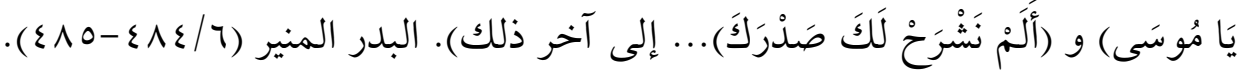
(r) شرح الزركشي على مختصر الخرقي(ع/ • • (r). 
المسوِّغ المقتضِي للتفضيل هنا من أحد أمرين:

إما أن يكون التفضيل بسبب فاقة الابن، أو مرضه، أو عجزه، أو كثرة عياله ....إلخ، فيكون الوالدُ في حقيقة الأمر هنا غيرَ مميٍٍّ أحدًا من أبنائه، إنما حاول تسوية هذا الولد بسائر إخوته، بتعويضه عن طريت هذه الهبة عما أصابه من عجز، أو عاقه من عوائق؛ ليتساوى في الفرص مع أقرانه، ومحاولة

التسوية ليست جورًا.

وإما أن يفضِّلَه بهبة لصلاحه وفساد الباقين، أو لغالب ظنه أن أحد ولده يستعين بالمال على الخير والطاعة، بينما يستعين الباقون بهذه العطية على الشرّ والفجور، فيكون الوالد هنا قد حاول إثابته ومكافأته، وتأديبَهم لينزجروا وليرتدعوا، وليكون حرمانهم داعيًا إلى إصلاحهم، ولعله.

بالإضافة إلى أن ترجيح القول بالجواز فيه جمعٌ بين الأدلة الواردة في المسألة، وعملُ بها جميعًا، والجمع بين الأدلة أولى من إعمال أحدها وإهمال الآخر؛ وبيان ذلك: أن حديث النعمان واردٌ بالأمر بالتسوية والنهي عن التفضيل، وقد ورد عن كبار الصحابة وقوع التفضيل منهم لبعض أبنائهم

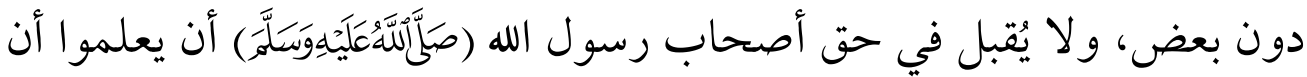

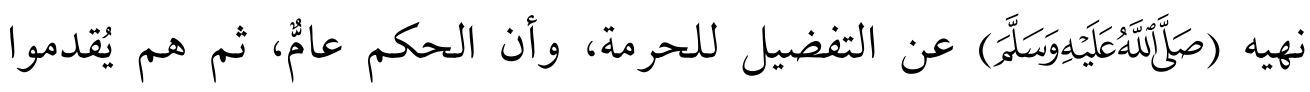

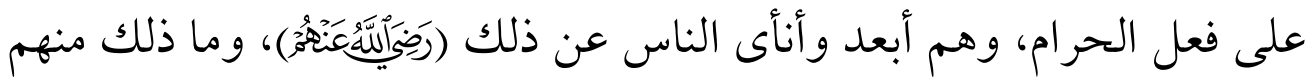

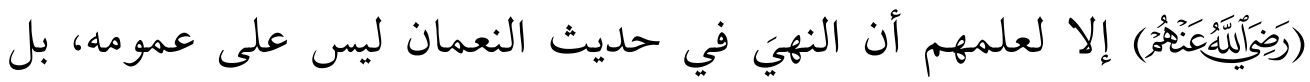
محمولٌ على ما إذا كان التفضيل لغير سبب يقتضيه، أما إذا كان له مسوغ، فلا يأخذ نفس الحكم. 
ويُنصح الآباء في مثل هذه الحالات بتقوى الله، وأن تكون نيتهم إصلاح

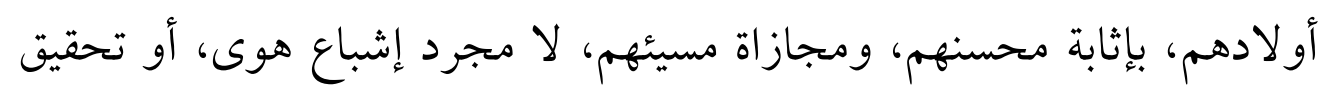

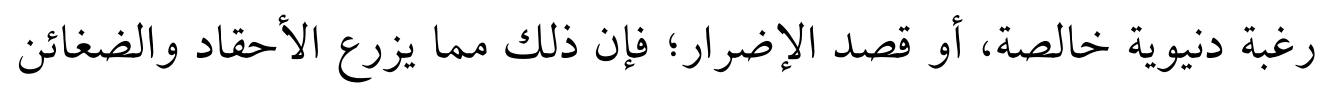

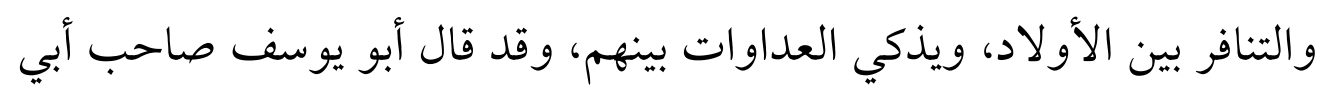
حنيفة: تجب التسوية إن قصد الإضرار (1).

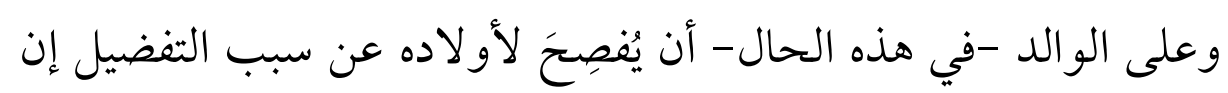

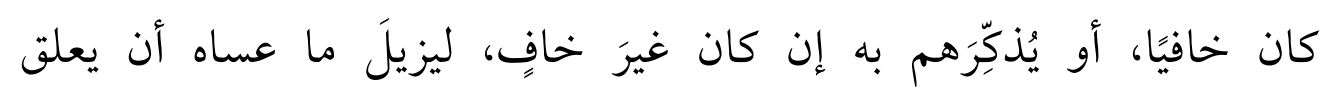

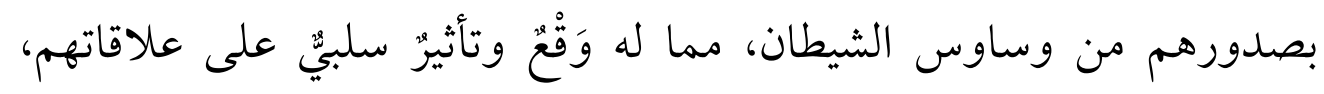

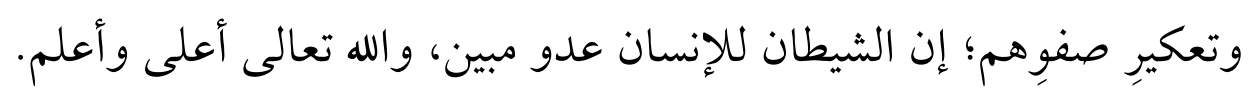

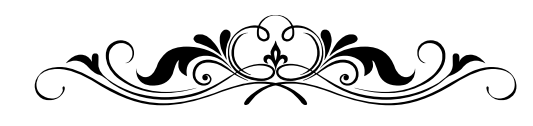

(1) سيأتي هذا القول لاحقًا ضمن أقوال الفقهاء في حكم تفضيل أحد الأبناء بعطية لغير سبب يسوِغ التفضيل. 


\section{المبحث الثالث}

حكم تفضيل الولد الذي عمل في مال و الده، أو كان سببًا ظاهرًا في تنميته وتكثيره

استعرضتُ في المسألة السابقة أقوال الفقهاء في حكم تفضيل الوالد لبعض أو لاده لوجود سبب يقتضي التفضيل، ورجحتُ القول بالجواز. ويثور هنا سؤال يكثر الاستفسار عنه، وهو: حكم تفضيل الولد الذي

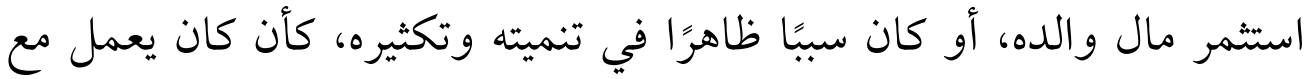

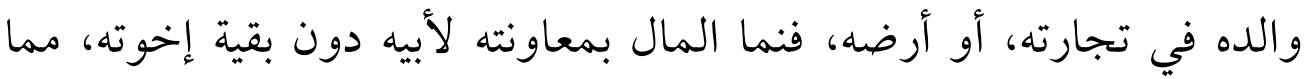
كان له أثر واضح في كثرة المال وزيادته.

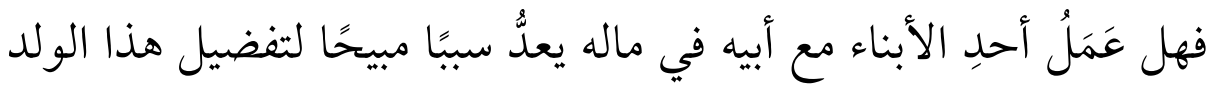

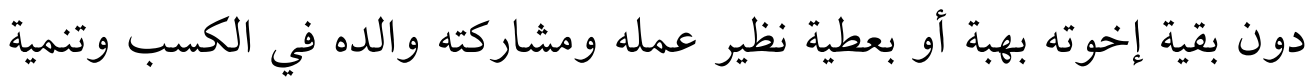

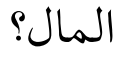

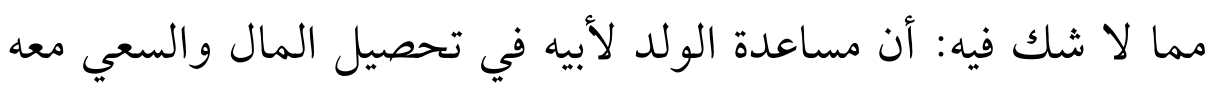

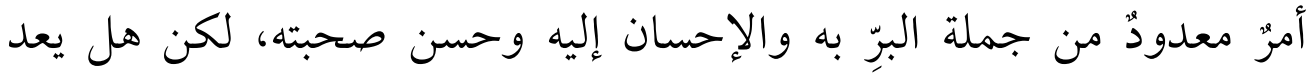

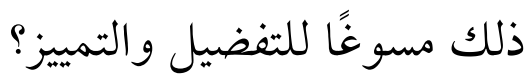

وللجواب عن هذا السؤال: يحسُن بي أن أستهلَّ الكلام بالتعرضِ

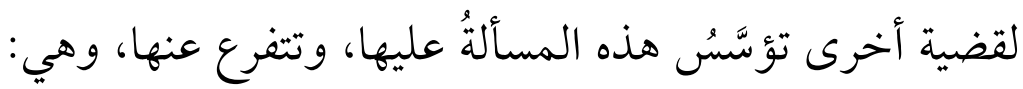

ما يحصَّله الابنُ من مالٍ وأرباحٍ نظير استثماره في مالٍ أبيه وتكثيره وتنميته، هل لهذا الابن العامل نصيب فيه، فتصح المطالبة به من جهتها، 
ولتكون عطيته من قبل والده دون بقية إخوته جائزة؟ أم ليس له نصيب فيه،

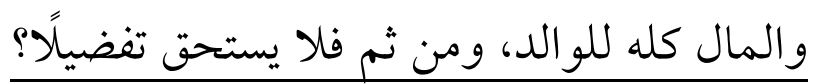

وقد كشف بعضُ الفقهاء اللثامَ عن هذه المسألة، ولهم فيها أقوال يمكن إجمالها في أربعة، أذكرها على النحو التالي:

القول الأول: أن المالَ كلَّه (أصله وغلته) للأبَ، وليس للولد العامل فيه شيء، إلا ما اكتسبه بنفسه بغير طريق مال الأب، كأن رعى غنمًا للغير، أو أجَّر نفسه للغير؛ فإن هذا المال له. وقد حكي هذا القول عن ابن مُزَينٍ المالكي (1)، وبه قال الإمام عليش المالكي (r)، وبه صرَّح ابنُ شرف الدين الخليلي

(1) فقد حكى صاحب التاج والإكليل لمختصر خليل عن ابن مُزَيْنٍ في أن: (من قال لابنه:

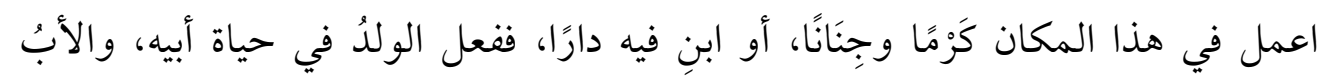

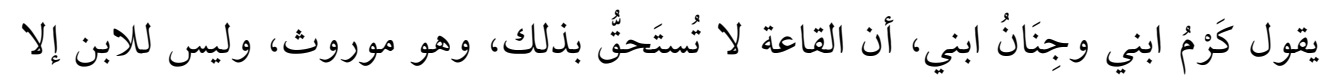
قيمة عمله منقوضًا.

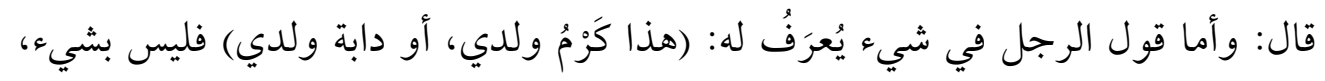

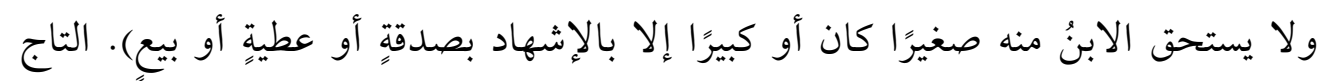

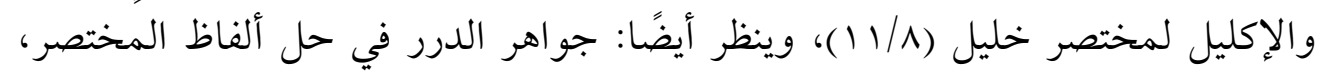

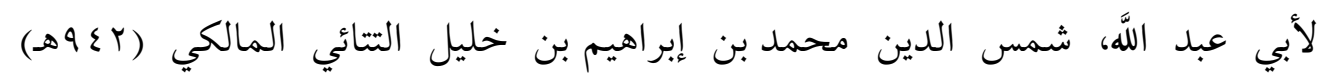

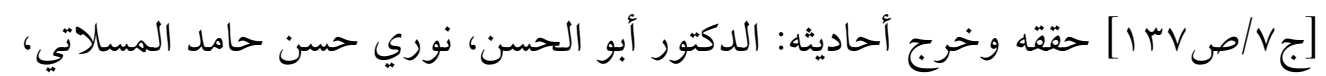

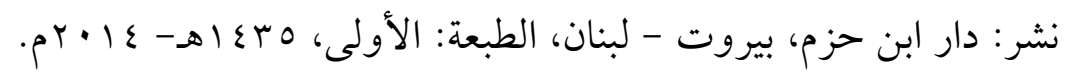

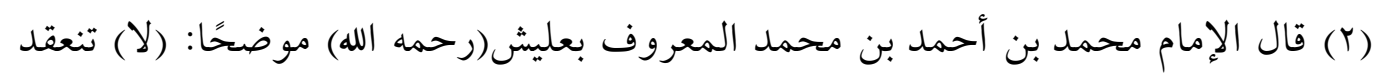

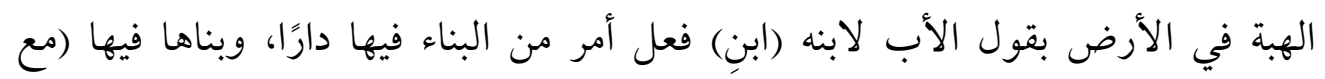

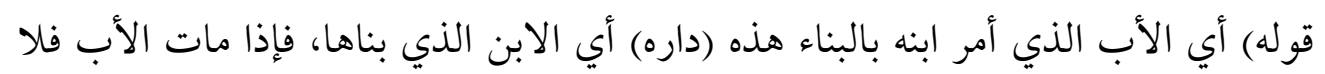
يختص الابن بالأرض ويشاركه فيها الورثة، وللابن قيمة بنائه منقوضًا، قاله ابن مزين، 


\section{الشافعي (1) - (1)}

فقد ذهبوا إلى أن الولدَ العاملَ مع أبيه في ماله، ليس له نصيب في هذا

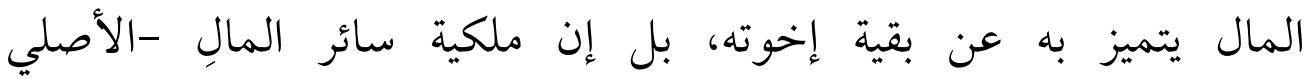

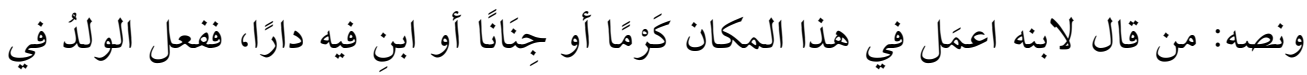

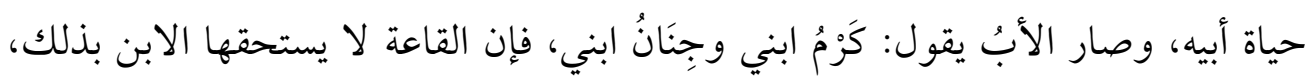

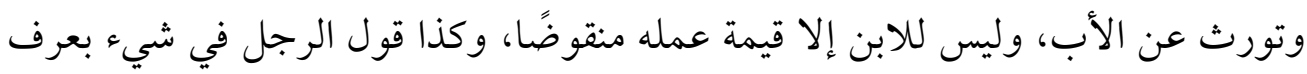

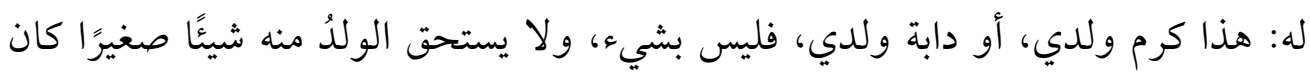

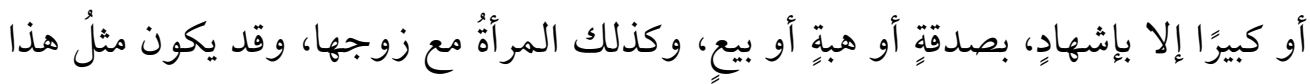

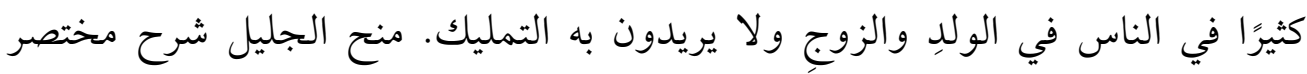

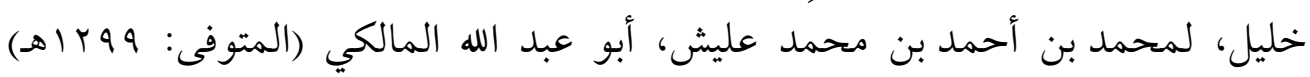

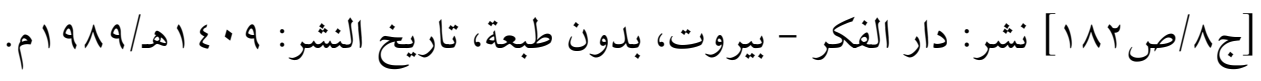

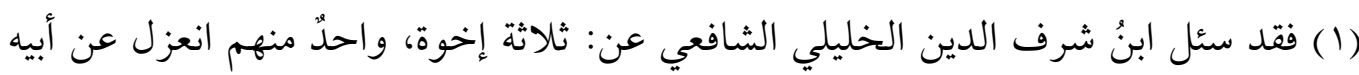

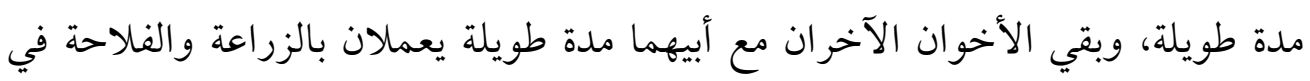

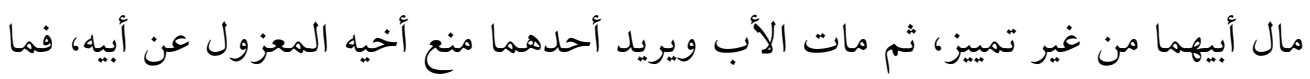

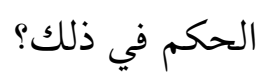

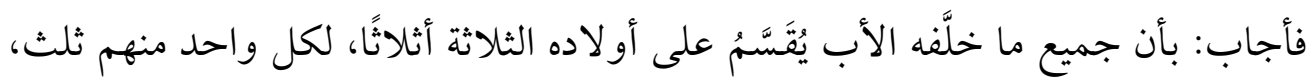

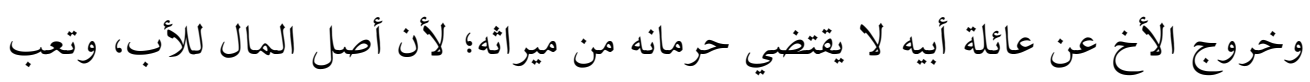

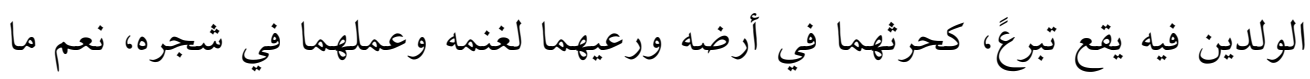

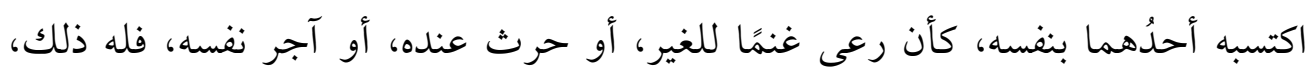

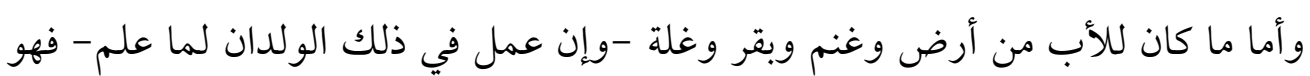

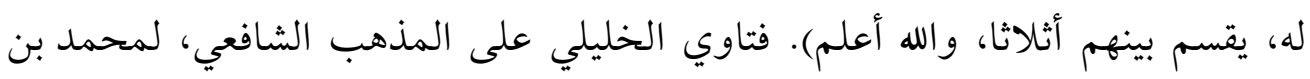

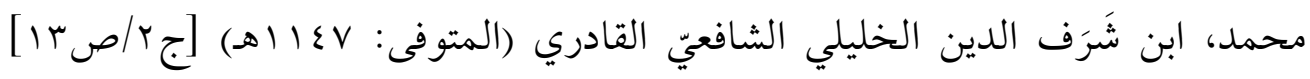
طبعة مصرية قديمة. 
والمكتَسبِ - تكون خالصةً للأبَ.

ومن ثم، لا يجوز تفضيله لهذا السبب، وينبغي على الأب إن خصَّه بعطية أن يسوي بينه وبين باقي الأولاد، فيعطيهم كما أعطاه.

واستدلوا لقولهم: بأن أصل المال للأب، وتعبُ الولد فيه يقع تبرعًا،

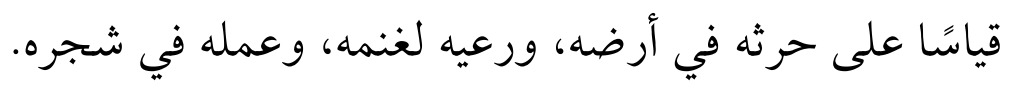

القول الثاني: أن الولَّ العاملَ في مالِ أبيه بمثابة الأجير، فلا يعدُّ شريكًا

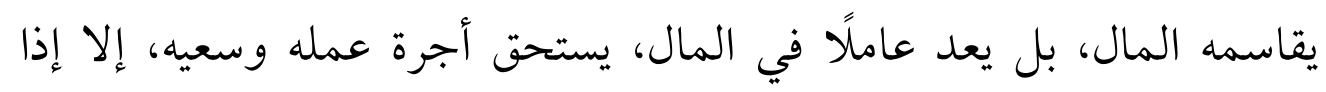

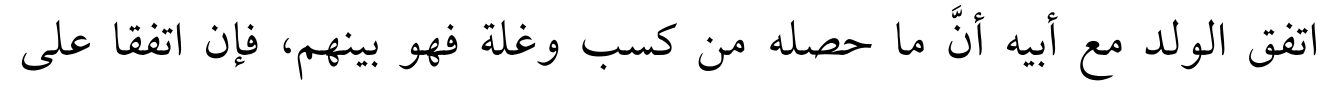

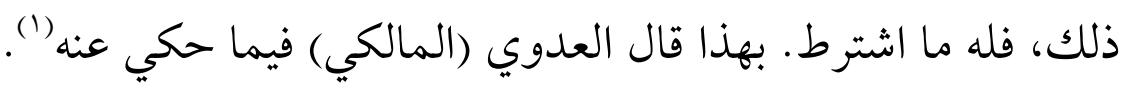

(1) قال الدسوقي: (وقرر شيخنا العدوي في هذا المحل ما محصله: لو عمل أولاد رجل في

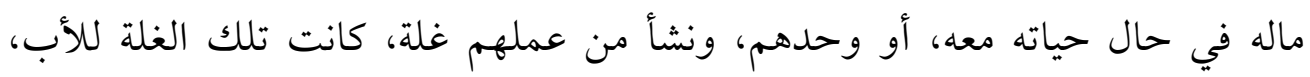

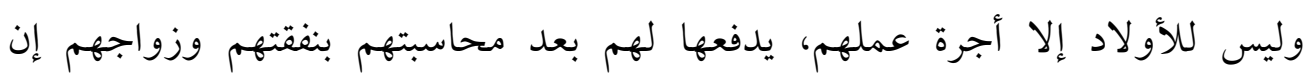

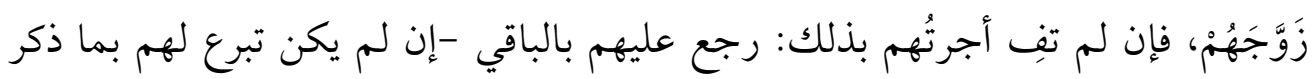

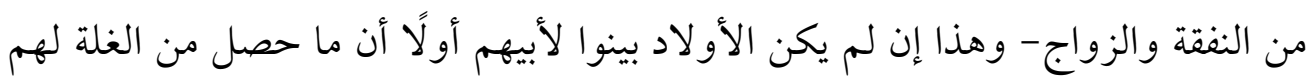

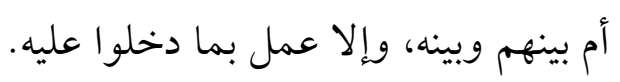

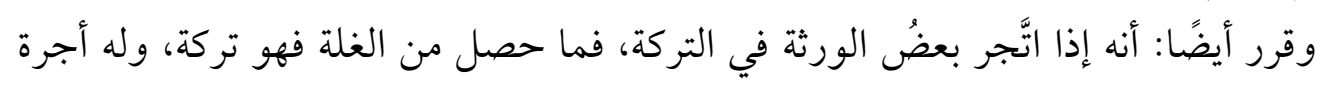

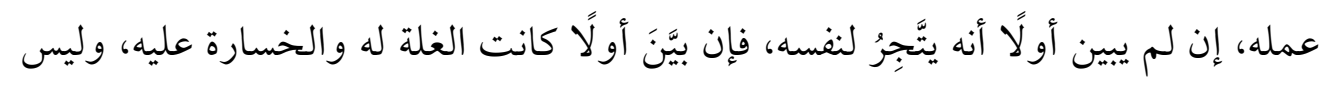

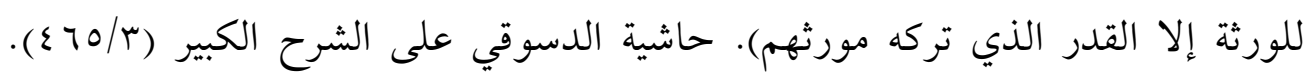

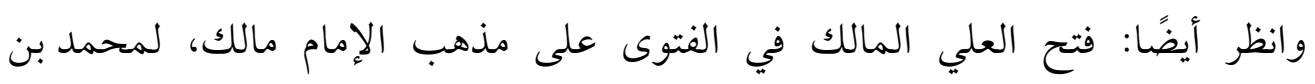

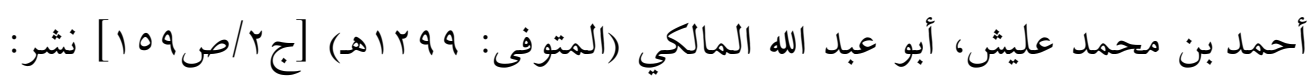

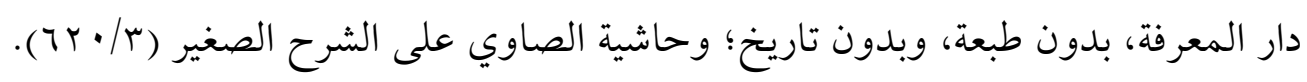


القول الثالث: أن المال للأب بشروط ثلاثة، متى توفرت جميعها، حُكِمَ

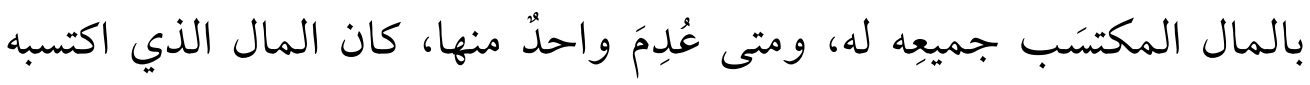

$$
\text { الابن للابن، وهذه الشروط هي: }
$$

r- كون الابن في عيال أبيه، أي يعوله الأب، ويتولى كافة شئونه.

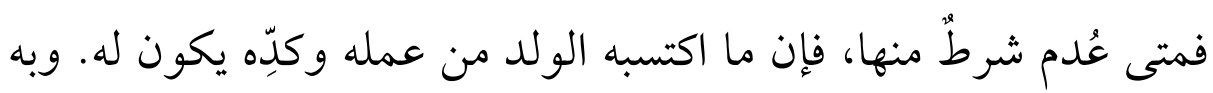

صرَّح ابن عابدين من الحنفية ومعه جماعة (1).

(1) فقد صرَّح بذلك أكثر من مرة من كتابه: العقود الدرية في تنقيح الفتاوى الحامدية، منها:

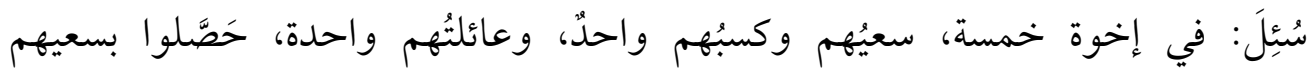

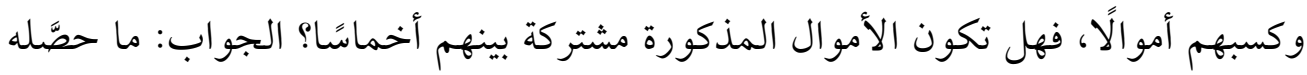

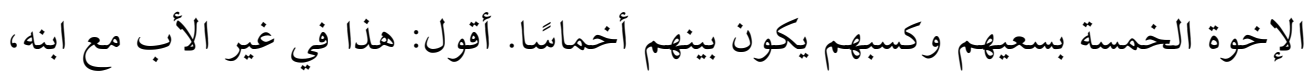

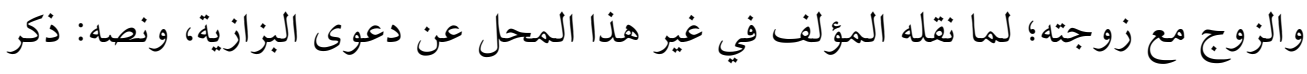

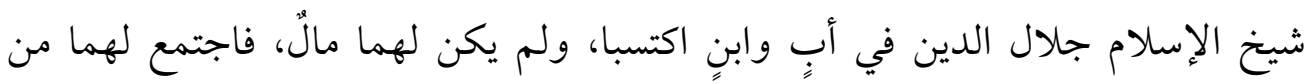

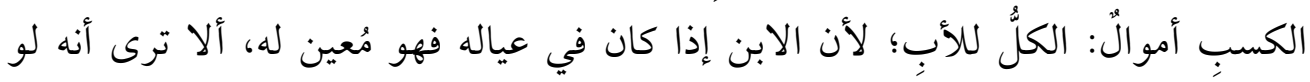

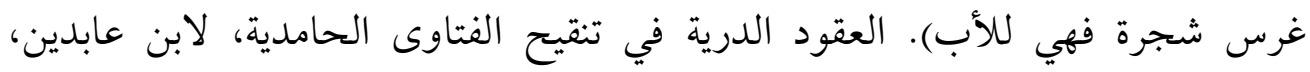

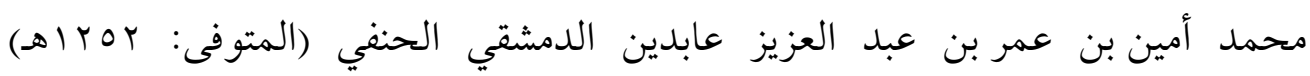

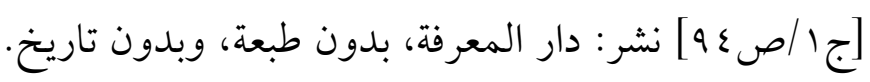

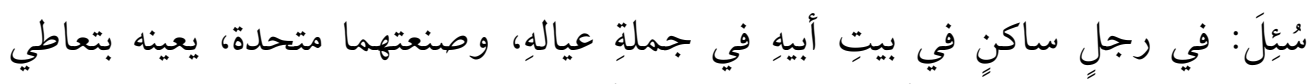

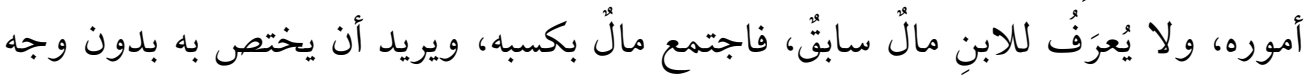
$=$

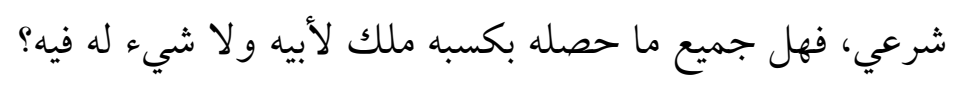




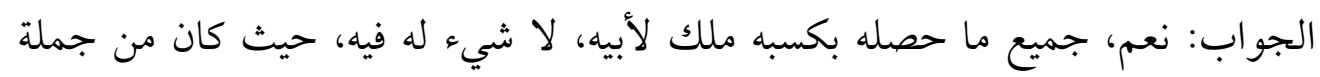

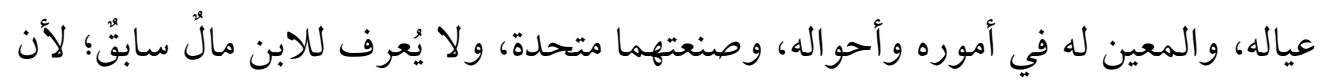

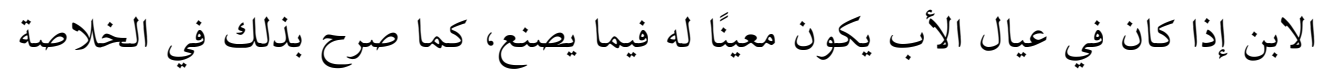

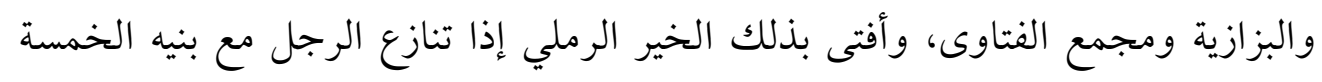

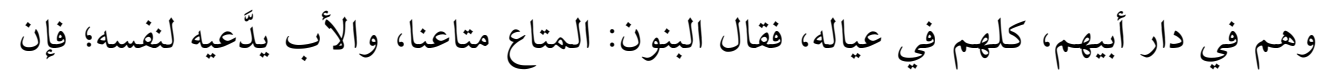

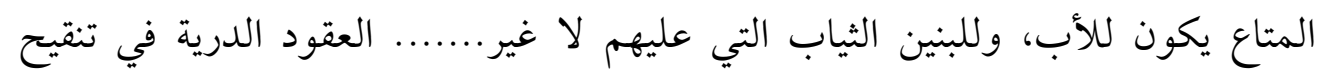

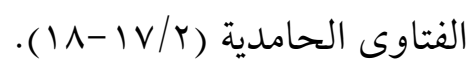

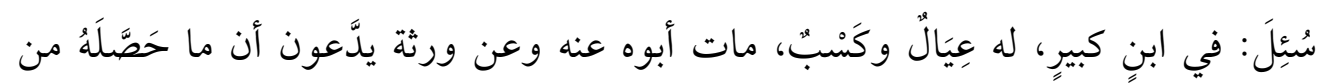

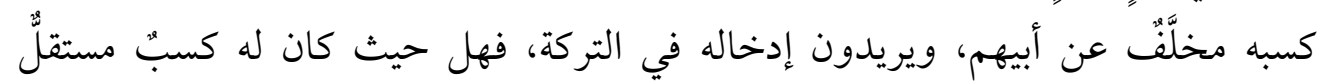

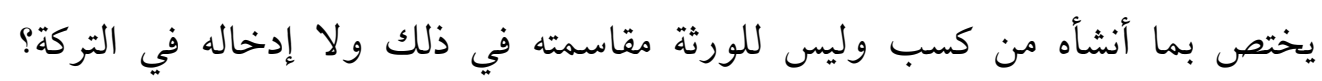

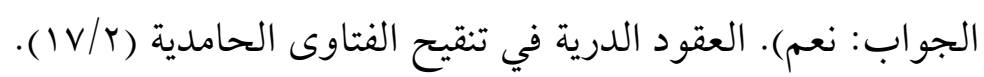

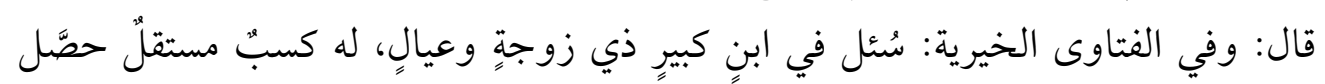

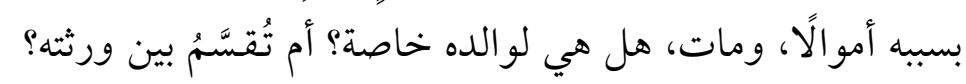

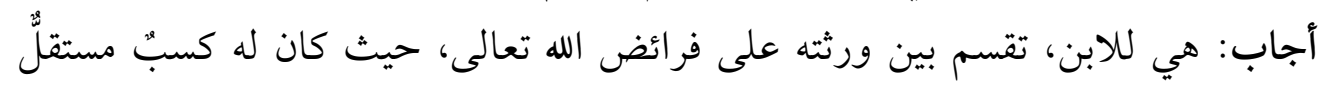

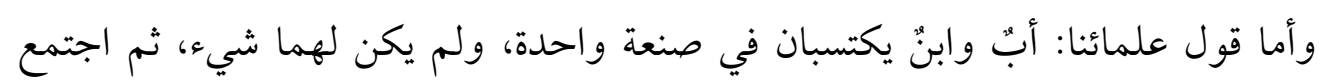

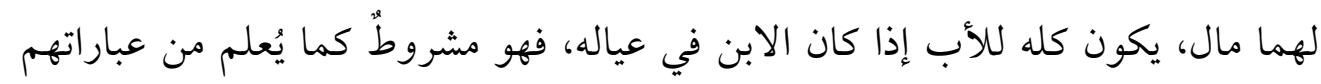

$$
\text { و و وعروط، منهاد }
$$

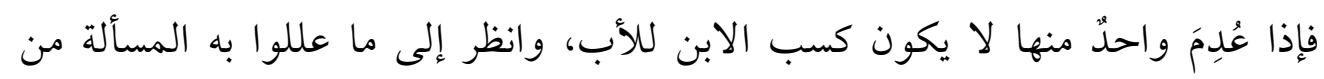

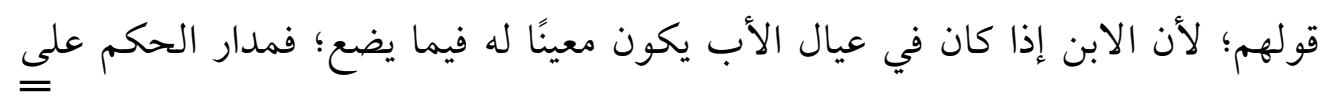


ثبوت كونه معينًا له فيه، فاعلم ذلك اهـ. وأجاب الخير الرملي عن سؤال آخر بقوله: حيث كان من جملة عياله، وانه والمعينين له في

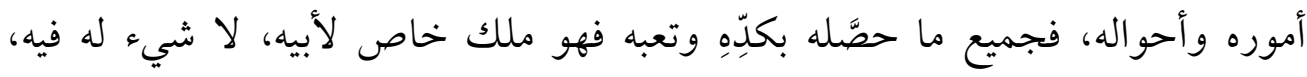

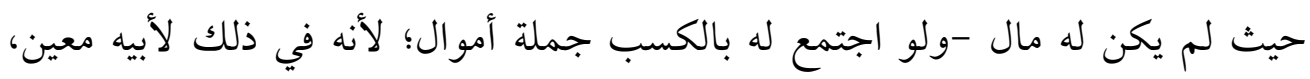
حتى لو غرس شجرةً في هذه الحالة فهي لأبيه، نص عليه علماؤنا (رحمهم الله تعالى)....

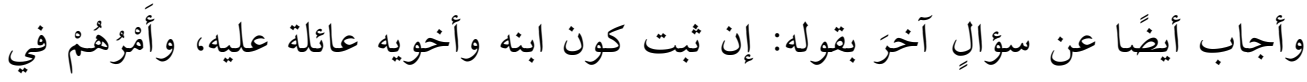

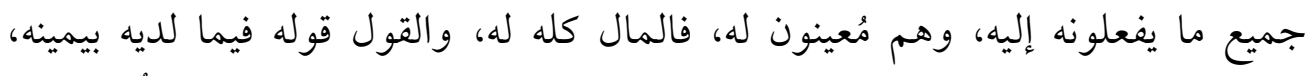

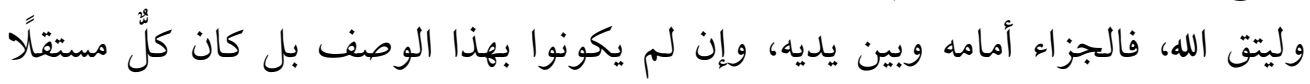

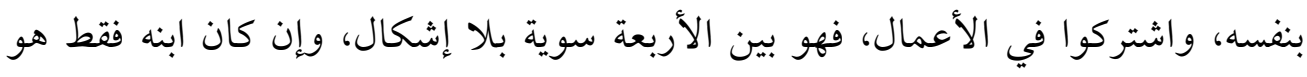

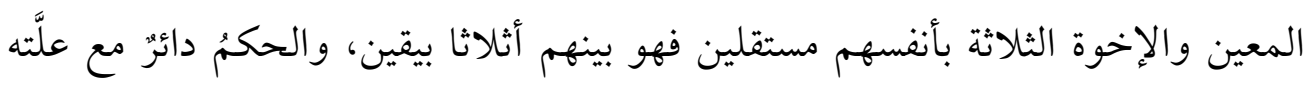

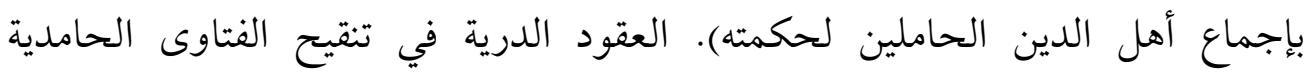
$\cdot(1 \Lambda-I V / r)$

وقد قال رحمه الله في حاشيته: (وكذا لو اجتمع إخوة يعملون في تركة أبيهم، ونما

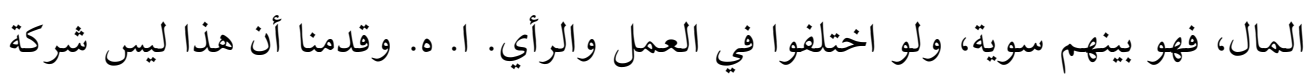

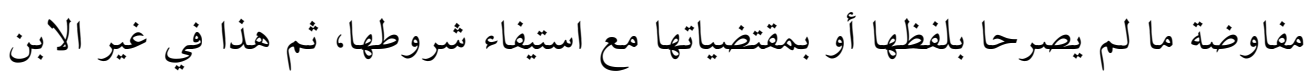

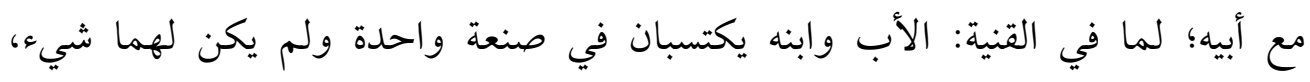

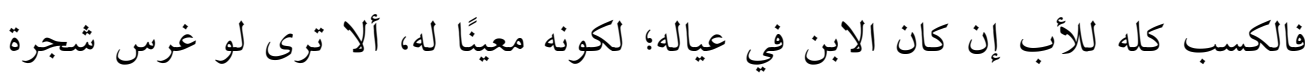

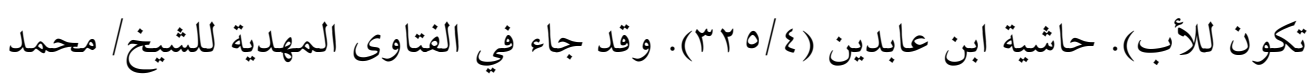

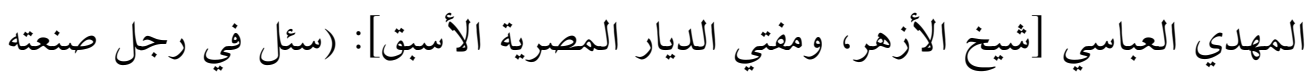

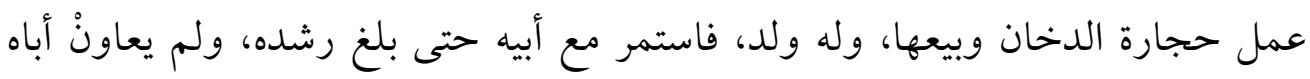

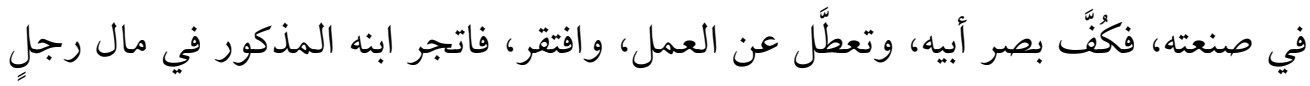

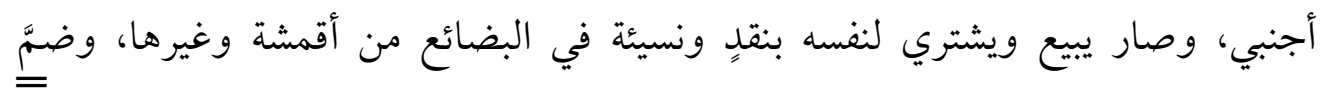


القول الرابع: أن الحكم في ذلك يرجع إلى عرف الناس وعادتهم، فإذا

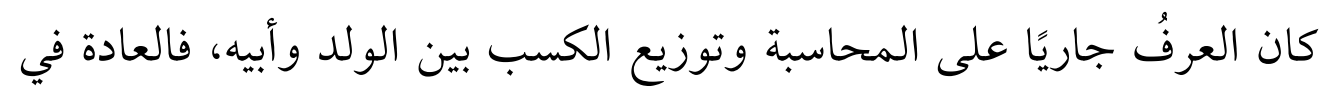

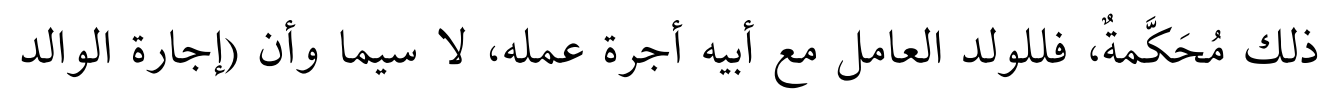

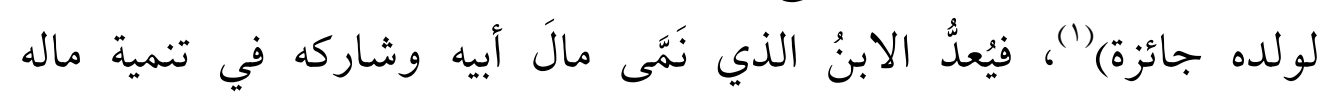

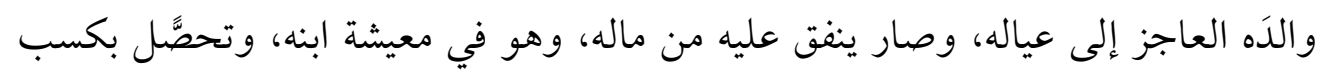

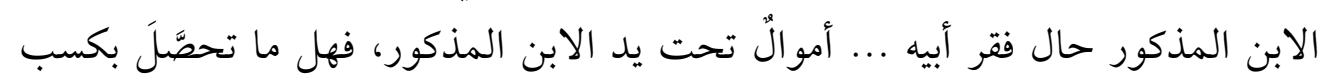

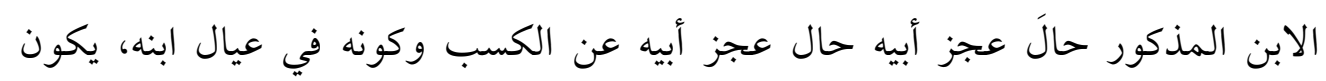

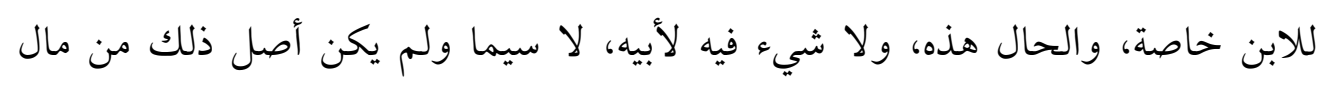

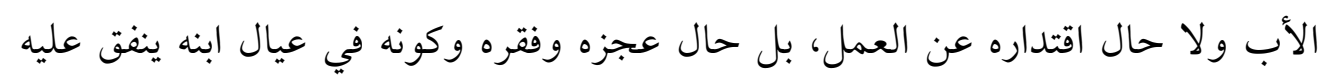
كسائر عائلته.

أجاب: إذا لم يكن الابن حال تكسبه في عيال أبيه ولا معينًا له في الكسب، بل كابل كان الكان

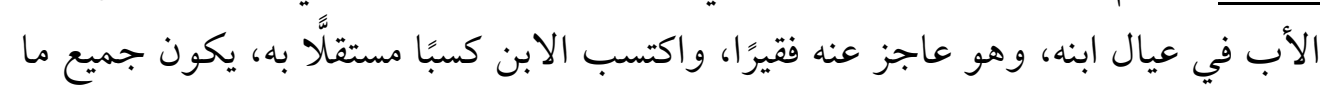

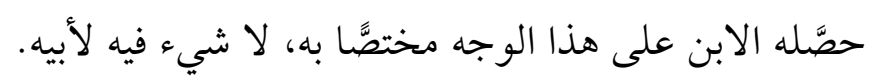

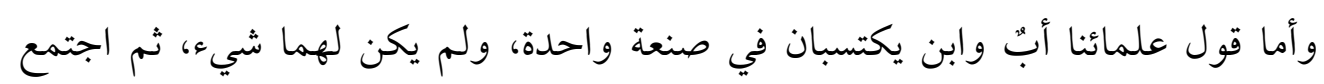

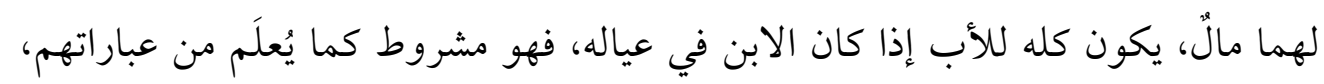

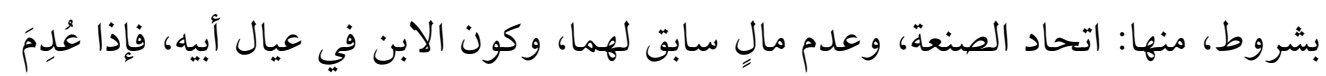

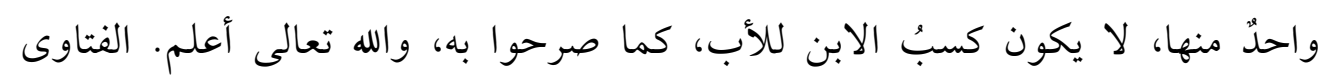

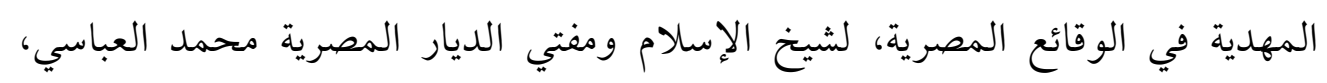

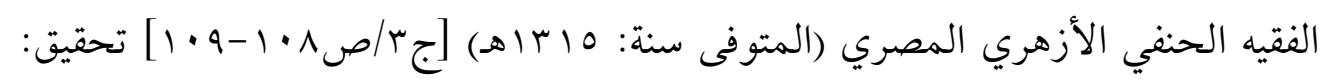

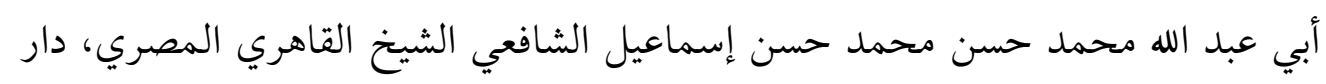

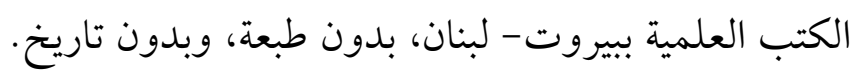

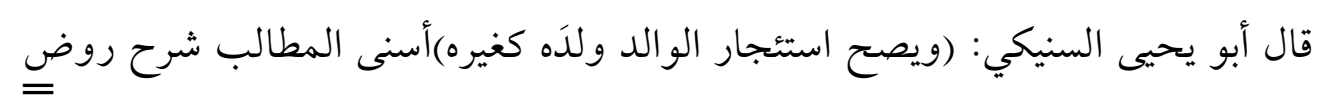


واستثماره وتكثيره، بمثابة العامل بأجر، أو يعد بمثابة الشريك المضارب، فالو الد شريك بماله، والابن شريك بجهده، فله أجرة ما عمل. أما إذا جرى العرف على عدم وقوع المحاسبة بين الولد وأبيه، وأن عمل الولد في مال أبيه من باب التبرع والعون ومطلق البر، فلا يستحق تفضياً، فشكر الله له صنيعه وجزاه خيرًا، غير أنه لا يستحق أجرًا نظير عمله

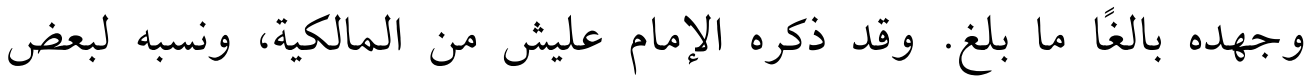

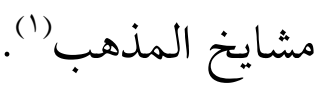

الطالب (r/• ع).

فقد ورد في كتابه فتح العلي المالك ما نصه: (ما قولكم في رجل له أموال، وتحت يده

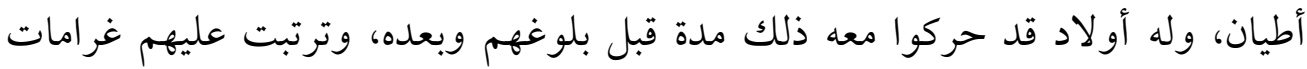

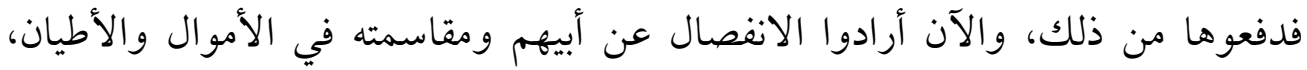
فهل يجابون لذلك؟ وإذا قلتم لا، فهل يلزم أباهم أن يدفع ما عليهم من الغرامة، أو لا،

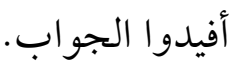

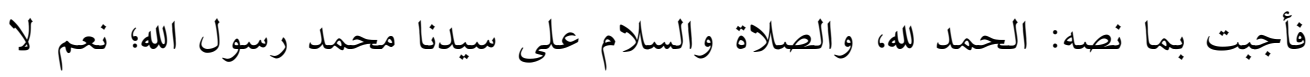

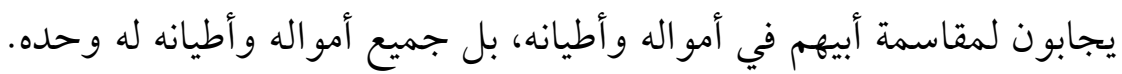

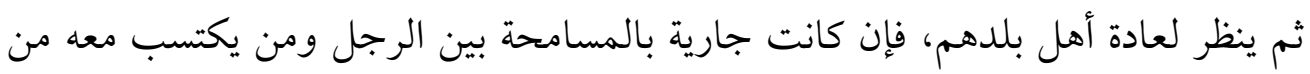

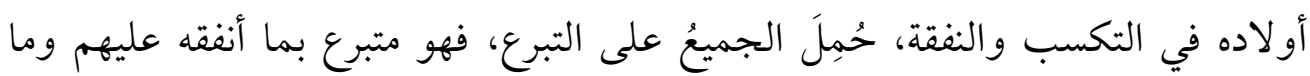

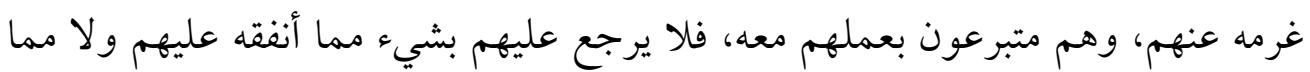

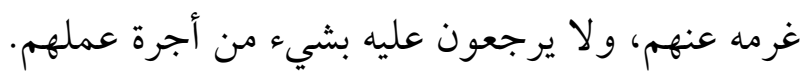

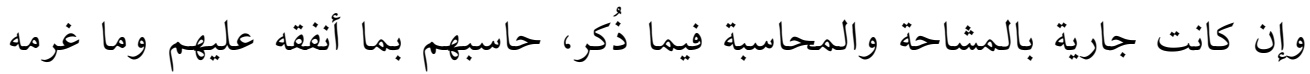

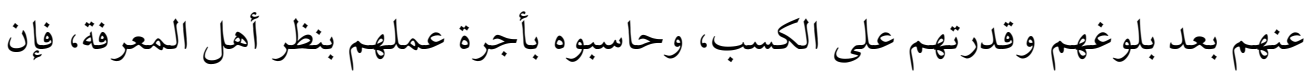

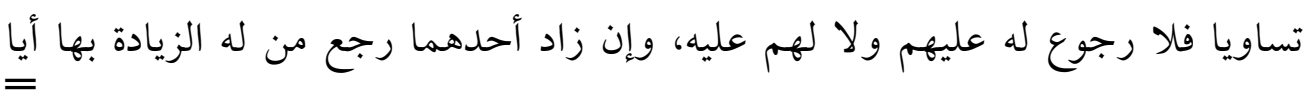


وتأسيسًا على ما سبق من أقوال الفقهاء في مدى استحقاق الولد العامل

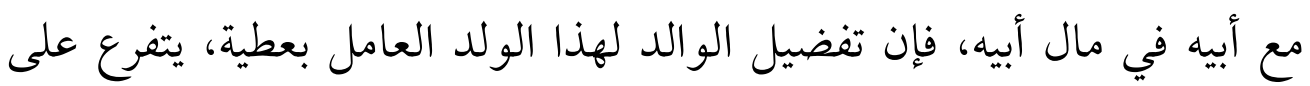
هذه المسألة، ويكون فيها أيضًا نفس الأقوال الأربعة المذكورة.

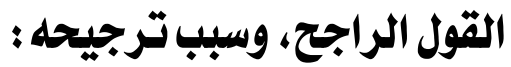

يرى الباحث رجحان القول القائل بأن الولد الذي عمل في مال أبيه،

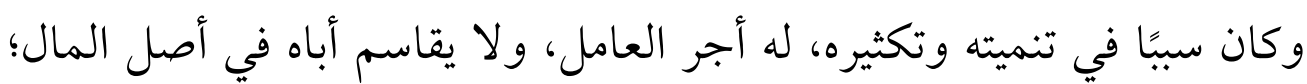

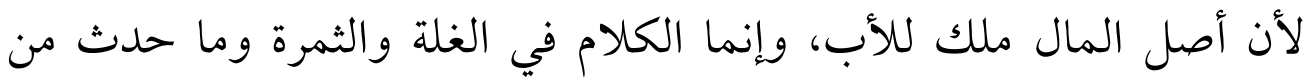

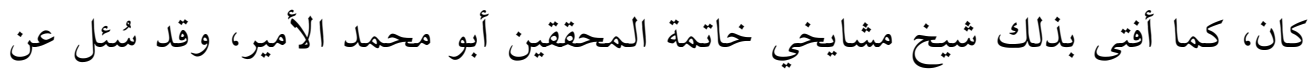

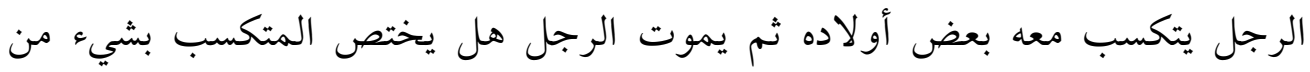

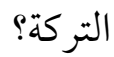

ونص الجواب: العادة محكمة في ذلك؛ فإن كان العرف في ذلك مبنيّا على المسامحة

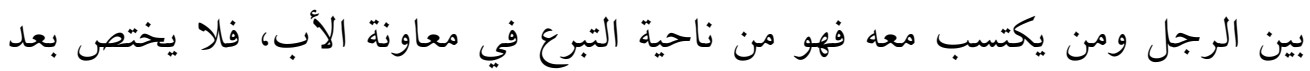

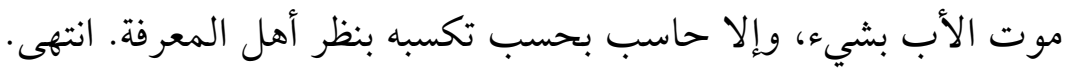

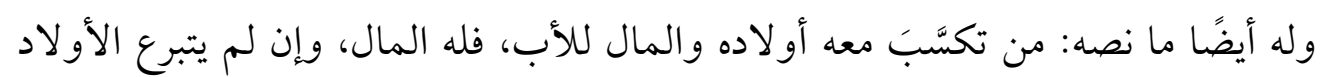

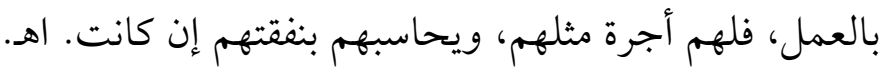

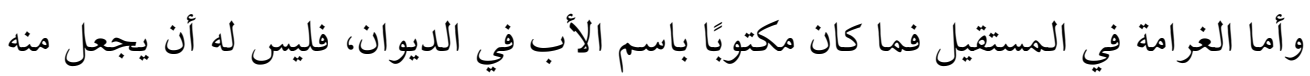

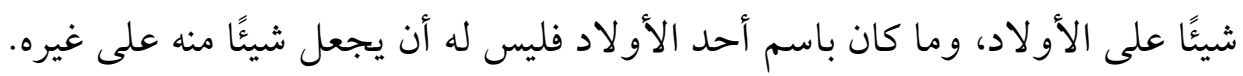

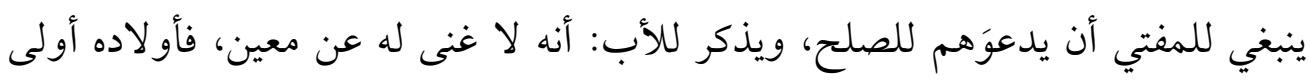

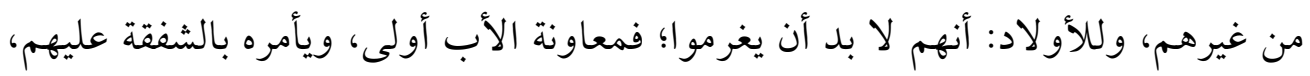

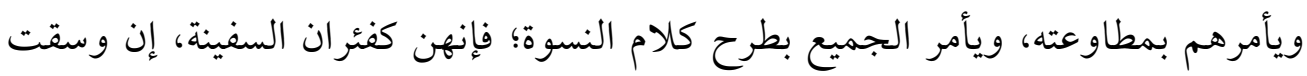

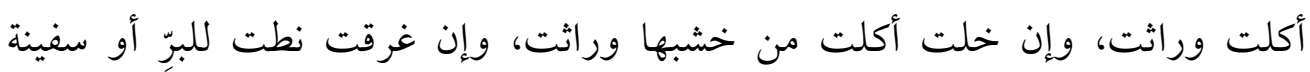

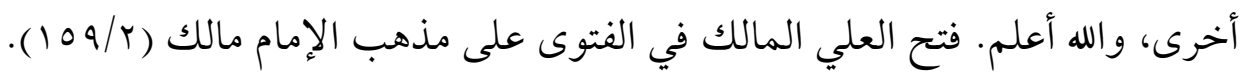


نماء وزيادة، فله فيه أجرة العامل، طالما تأثر المال بعمله من حيث النماء والربح والزيادة.

والرجوع في تقدير الأجر-عند التنازع- إلى أهل الخبرة، ليتم التقدير

باعتبار نوع العمل، وقدر الجهد المبذول، ومدته، وأثره في المال، وغير ذلك لك من أمور تحتاج إلى معرفة ودراية بها.

هذا إذا لم يتفق الأب وابنه من بداية العمل أن ما حصَّلاه من كسب فهو بينهما، فعند حصول هذا الاتفاق، يكون الأمر على ما اشترطا.

وفي ترجيح هذا القول تحقيق للعدل، ومجافاةٌ للجور، ومجانبةٌ للإجحاف، ومراعاةٌ واعتبارٌ لقواعد الإنصاف التي تقضي بعدم إهدار جهد العامل وعدم تضييع كدِّه وسعيه.

وتأسيسًا على ما سبق: يجوز للأب أن يهب في حياته هذا الولد العامل في ماله، ويخصه بالهبة دون بقية إخوته، ولا إثم عليه في ذلك؛ فهو من باب إيصال الحق لصاحبه، وإعطاء الأجير أجره.

وتتميمًا للمسألة أقول: لا ينبغي للوالد أن يعطيه فوق حقه المقرر له

عرفًا وتقديرًا.

وينبغي التنبيه على أن الأب إذا مات قبل أن يعطيَ ابنَه أجرةَ عمله، فلا يحق للابن أن يأخذ أكثر من نصيبه من التركة بحجة أنه عمل مع والده؛ لأن التركة ملك لجميع الورثة، إلا في حالتين: الأولى : إذا كانت ثمَّت بينة تثبت اتفاقه مع والده أن يدفع له أجرة نظير عمله. 
والثانية: إذا كان العرفُ جاريًا بذلك.

فإن كانت إحدى الحالتين، فإن أجرة هذا الولد تكون دَينًا على التركة، يأخذها قبل قسمة الميراث، ثم يأخذ نصيبه الشرعي من الميراث، والله أعلم. 


\section{المبحث الرابع}

\section{تفضيل الوالد بعضَ أولاده، لغير علة تقتضي التفضيل}

قد يقوم بعض الآباء بتمييز بعض أبنائهم دون بقيتهم بغير سبب يقتضي ذاك التمييز، أو يفضله لسبب غير معتبر شرعًا وعقاً، فما الحكم التكليفي

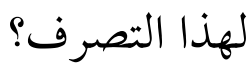

\section{للفقهـاء في هذه المسألة ثلاثة أقوال:}

القول الأول: الحُرمة. فإن فضَّل أحدَهم أَثْمَ، ويجبَ عليه التسوية بأحد

أمرين؛ إما ردُّ ما فضَّل به البعض، وإما إتمام نصيب الآخرين ليتساووا بالمفضَّل. قال طاووس: لا يجوز ذلك، ولا رغيف محترق (1)، وبه صرح البخاري، وهو قول ابن المبارك، وروي معناه عن مجاهد، وعروة، وهو ظاهر

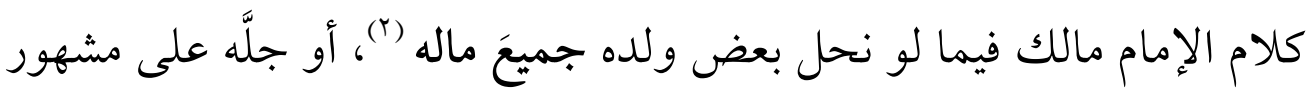
ونسب القول إليه بعدم الصحة أيضًا: الشاشي القفال. ينظر: حلية العلماء في معرفة

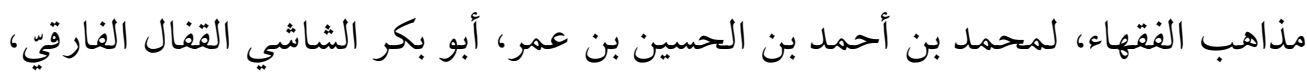

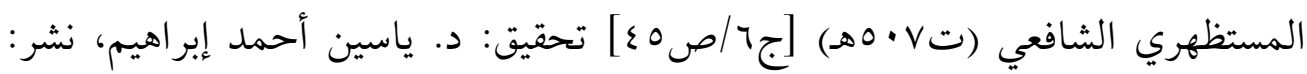

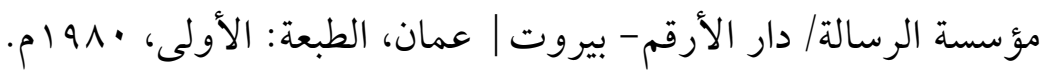
(r) قال ابن رشد: (وسُئل: عن الرجل يتصدق بماله كله على بعض ولده دون بعض، قال

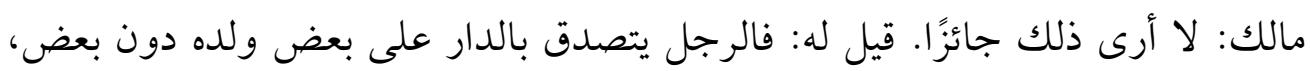

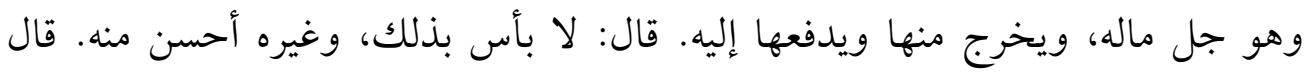

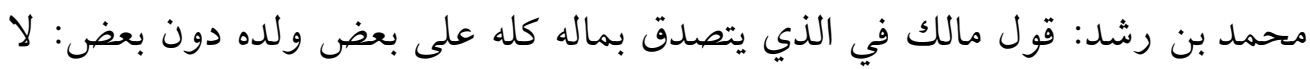

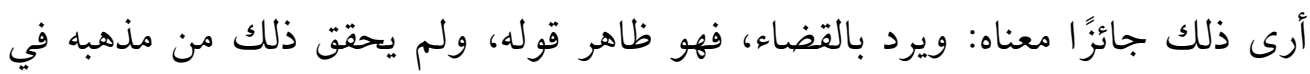

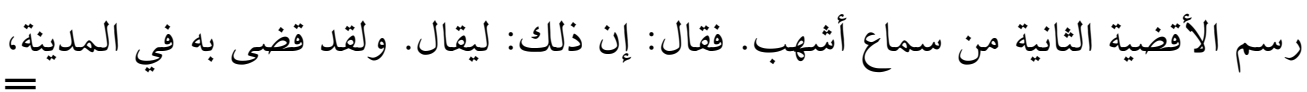




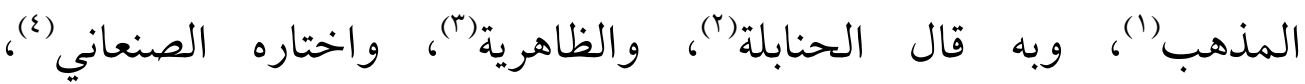
و الشو كاني (0)

وقول سحنون مفسر لقول مالك؛ لأنه إذا لم يستبق من ماله ما يكفيه فهو بمنزلة إذا تصدق بماله جميعه، ولم ير ابنُ القاسم إذا تصدق بجميع ماله على بعض ولده أن يُرََّّ ذلك بقضاء). البيان والتحصيل والشرح والتوجيه والتعليل لمسائل المستخرجة، لأبي

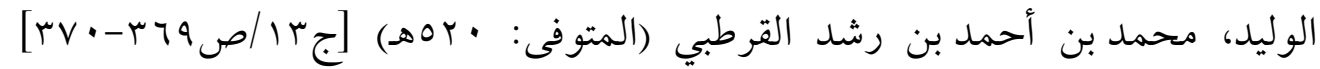
حققه: د محمد حجي وآخرون، نشر: دار الغرب الإسلامي، بيروت - لبنان، الطبعة:

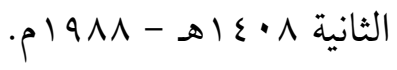

(1) الفو اكه الدواني على رسالة ابن أبي زيد القيرواني، لأحمد بن غانم بن سالم ابن مهنا،

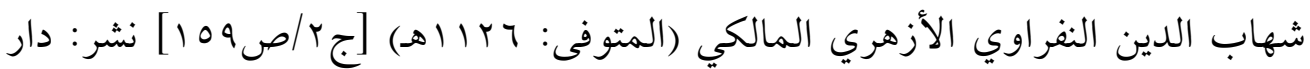
الفكر، بدون طبعة، تاريخ النشر: 10 اع اهـ - 990 ام.

ومحل وجوب التعديل في: هبة شيء غير تافه؛ لأنه يتسامح به، فلا يحصل التأثر. مطالب أولي النهى في شرح غاية المنتهى (ع/. · ع). وينظر في حكاية المذهب: المغني

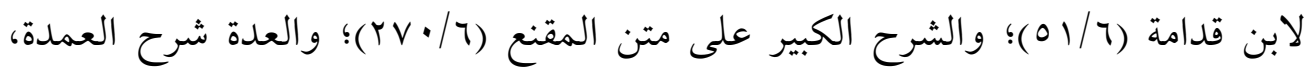
لعبد الرحمن بن إبراهيم بن أحمد، أبو محمد بهاء الدين المقدسي (المتوفى: عا7هـ)

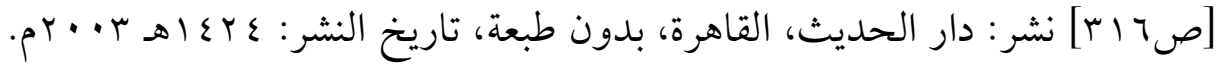
(r) قال ابن حزم: (ولا يحل لأحد أن يهب، ولا أن يتصدق على أحد من ولده إلا حتى يعطي أو يتصدق على كل واحد منهم بمثل ذلك. ولا يحل أن يفضل ذكرا على أنثى، ولا أنثى على ذكر، فإن فعل فهو مفسوخ مردود أبدا ولا بد). المحلى بالآثار(1/ (90). سبل السلام، لمحمد بن إسماعيل بن صلاح بن محمد الحسني، الكحلاني ثم الصنعاني، أبو إبراهيم، عز الدين، المعروف كأسلافه بالأمير (المتوفى: بما اهـ) [ج /ص • برا] نشر: دار الحديث، بدون طبعة وبدون تاريخ. قال: (فالحق أن التسوية واجبة، وأن التفضيل محرم)؛ ونيل الأوطار، لمحمد بن علي بن 


\section{وحكي عن ابن حبان(1).}

القول الثاني: الكراهة. فحملوا الأمرَ الوارد بالتسوية بين الأبناء على الندب، وحملوا النهيَ عن التفضيل بينهم على التنزيه. نسبه ابن رشد إلى إلى جمهور فقهاء الأمصار (r)، وقال الصاوي في حاشيته بأنه متفق عليه (r)، ونسبه ابن حجر إلى أكثر العلماء (ع)، وكذلك ابن عبد البر (0)، والشربيني (ج)، ونسبه

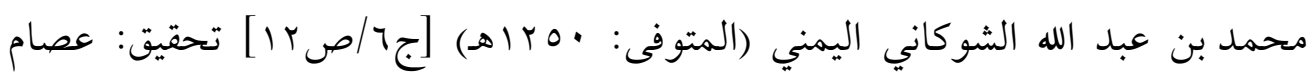

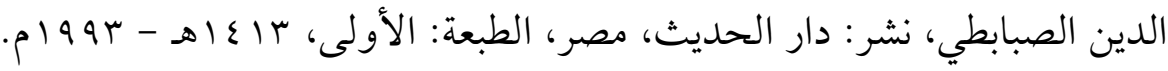

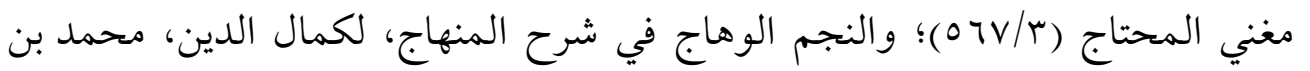

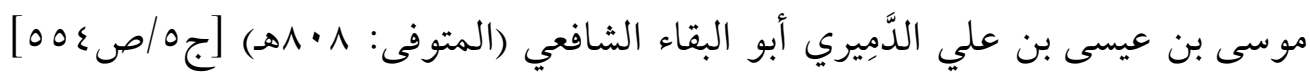

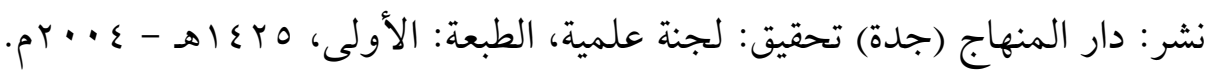

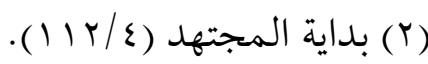

(r) حيث قال: (وأما هبة الرجل لبعض ولده ماله كله كله أو جله، فمكروه اتفاقًا). حاشية

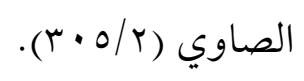

(ع) حيث قال: (وقال أكثر العلماء بالكراهة فقط). الفتاوى الفقهية الكبرى، لأحمد بن

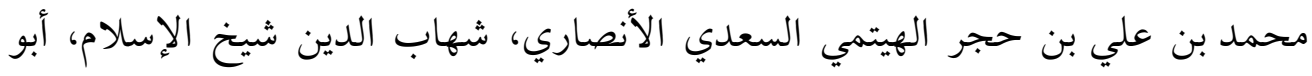

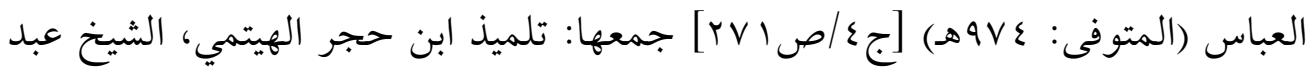
القادر بن أحمد بن علي الفاكهي المكي (المتوفى r هAهـ) نشر المكتبة الإسلامية. (0) قال ابن عبد البر: ( أكثر الفقهاء على أن معنى هذا الحديث: الندب إلى الخير والبر

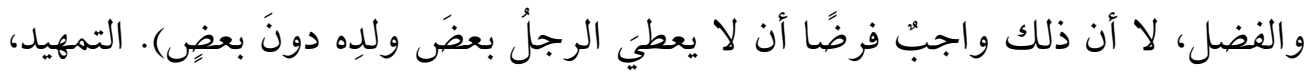

$$
\text { لابن عبد البر (Y/ • r (Y). }
$$


القرطبي إلى الأئمة: الثوري، وابن المبارك، وإسحاق(')، وهو ظاهر مذهب الحنفية(r)، وهو مروي عن الإمام مالك فيما لو نحل بعض ماله -ولو جله واستبقى بعضه، وهو مشهور المذهب ()'، وبه قال الشافعي (ع).

(1) الجامع لأحكام القرآن = تفسير القرطبي، لأبي عبد الله، محمد بن أحمد بن أبي بكر بن

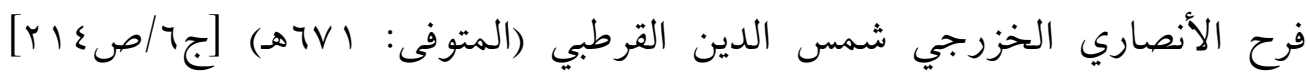
تحقيق: أحمد البردوني وإبراهيم أطفيش، نشر: دار الكتب المصرية - القاهرة، الطبعة:

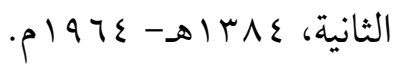

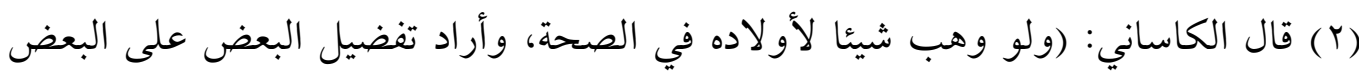

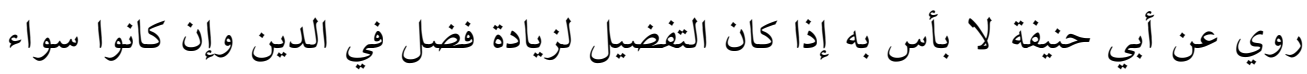

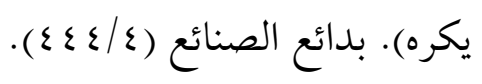
(rr) قال ابن رشد: (وأما إذا أعطى بعض ولده دون بعض ماله، وإن كان جله، وأبقى لنفسه

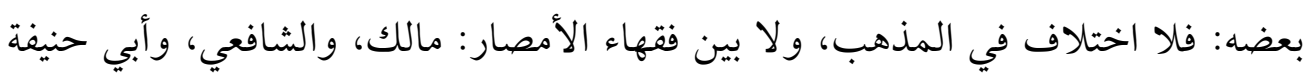

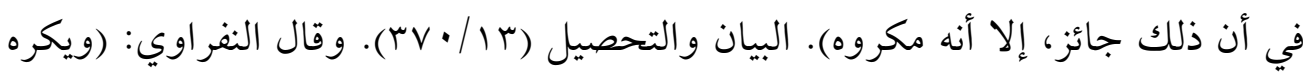
كراهة تنزيه للشخص في حال صحته أن يهب لبعض ولده ولو صغيرًا أو مريضًا ماله كله اله

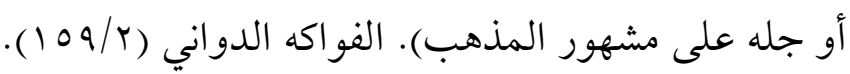

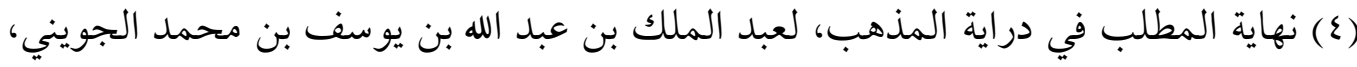

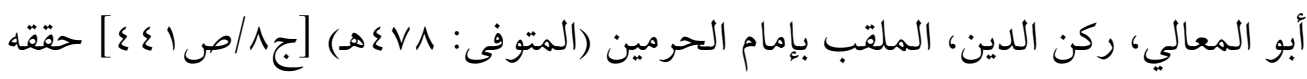

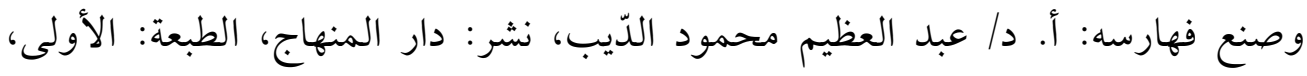

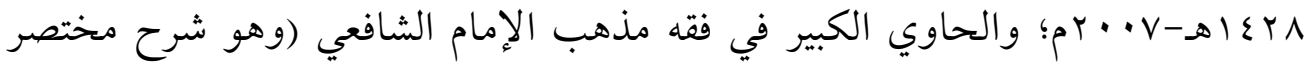

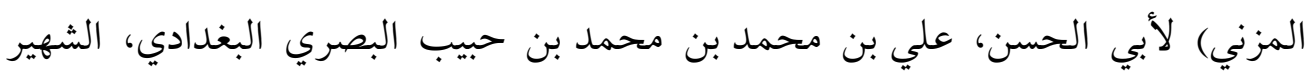

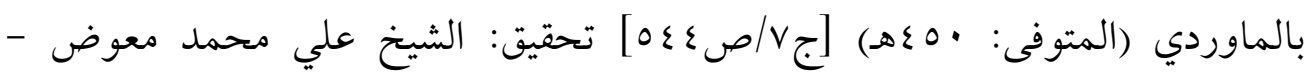
الشيخ عادل أحمد عبد الموجود، نشر: دار الكتب العلمية، بيروت - لبنان، الطبعة:

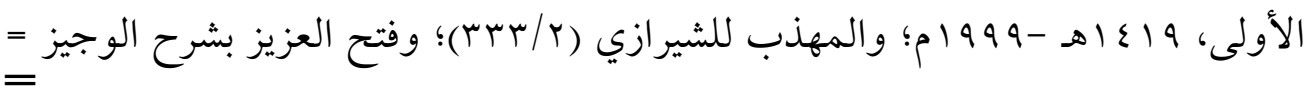


الشرح الكبير [وهو شرح لكتاب الوجيز في الفقه الشافعي لأبي حامد الغزالي (المتوفى:

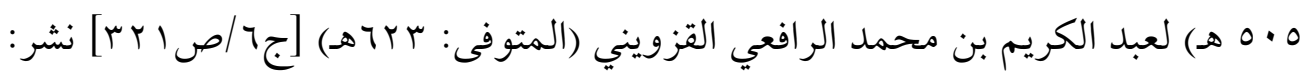

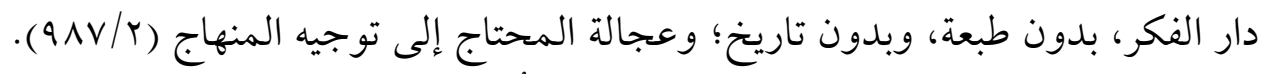

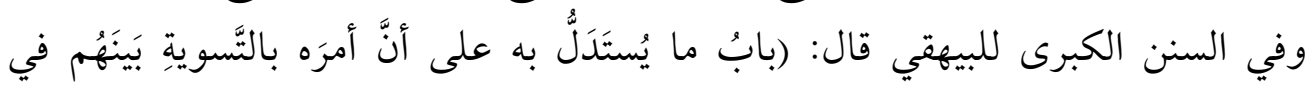

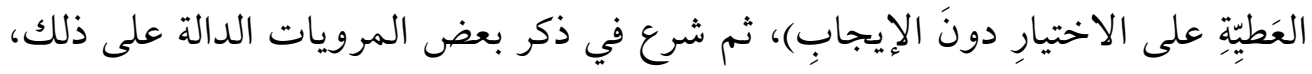

ومنها:

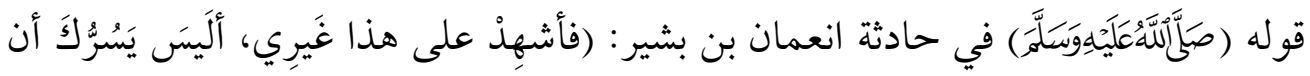

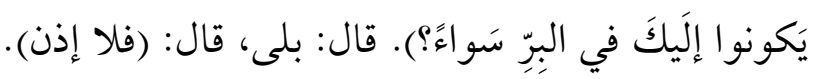

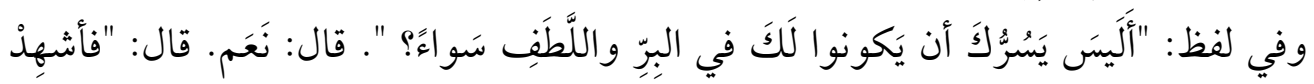

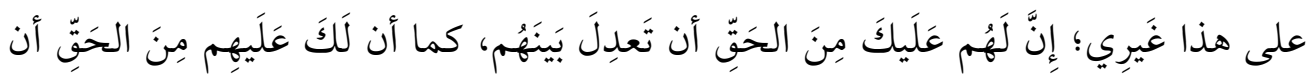

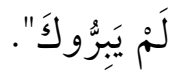

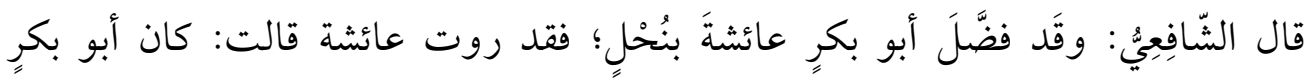

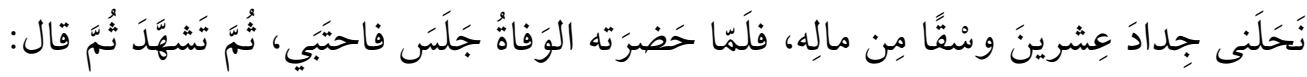

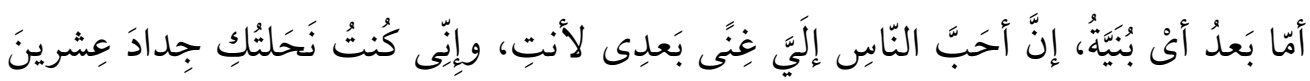

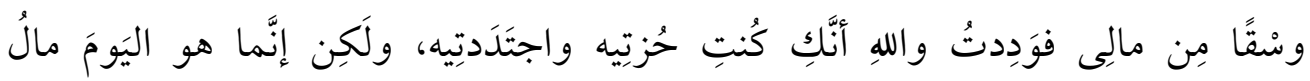

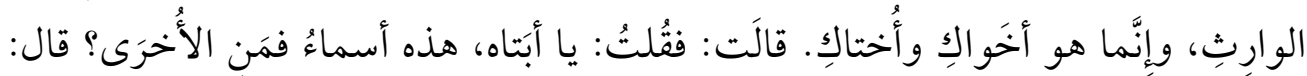

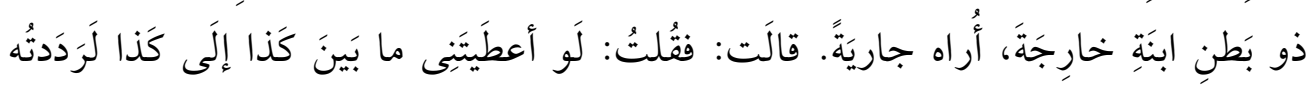

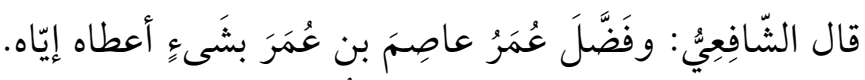

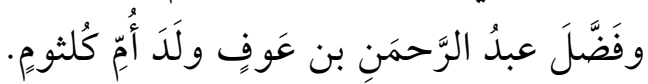

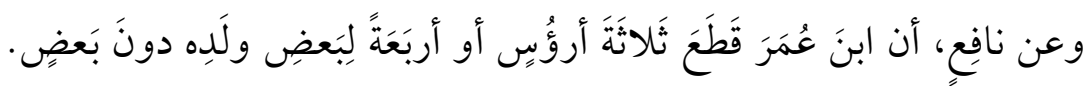

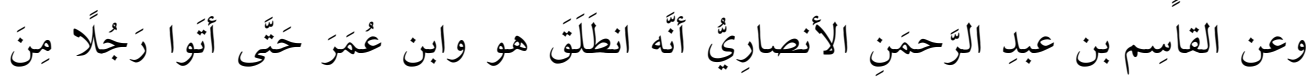

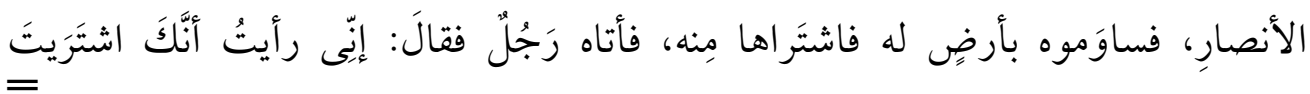


القول الثالث: الجواز. وهو قول الثوري، فقد قال: (لا بأس أن يخصَّ

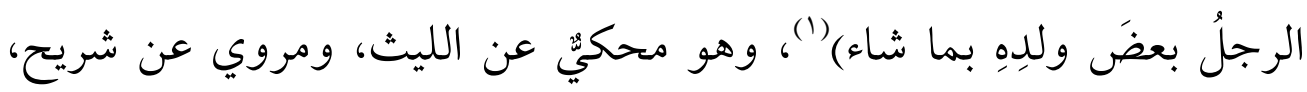

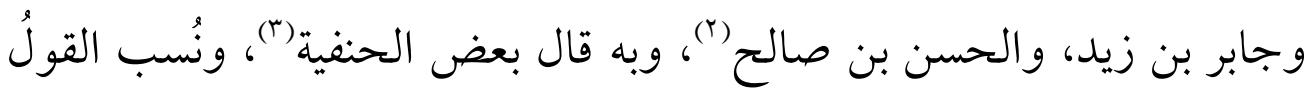

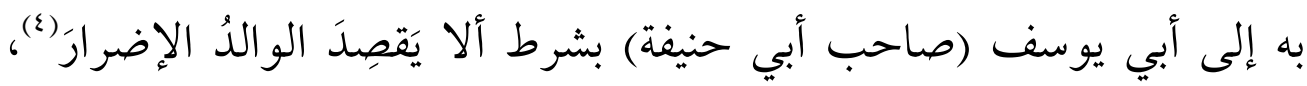
وهو محكي عن بعض المالكية إذا لم ينحلْه جميعُ ماله (0).

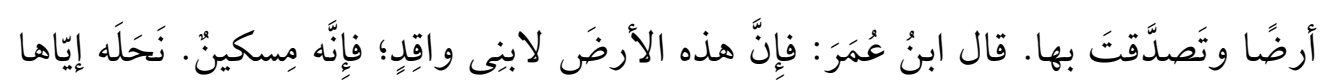
دونَ ولَدِدِه.

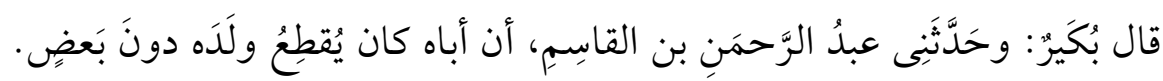

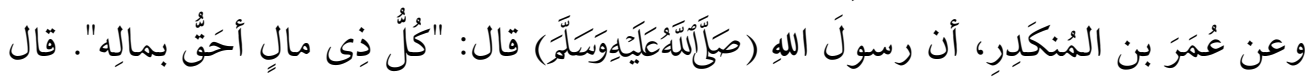

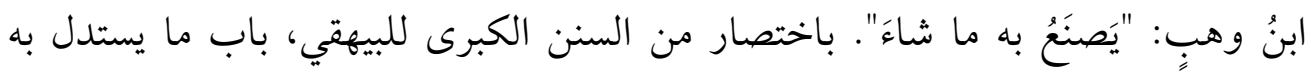

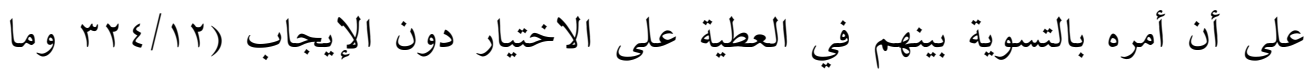

$$
\text { بعدها). }
$$

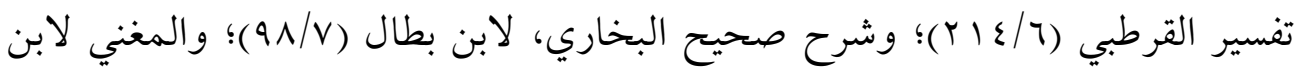

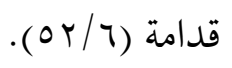

(r) وفي الخانية: لا بأس بتفضيل بعض الأولاد في المحبة لأنها عمل القلب، وكذا في

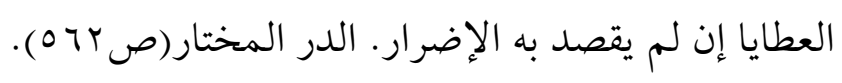

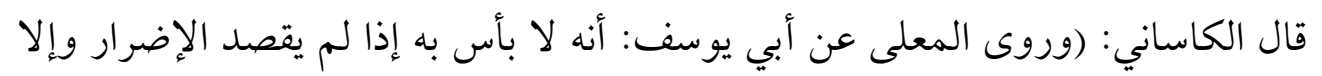

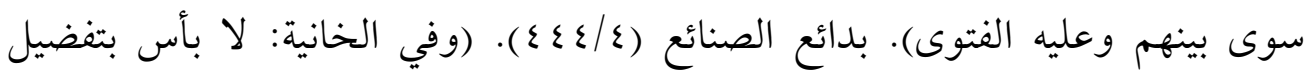

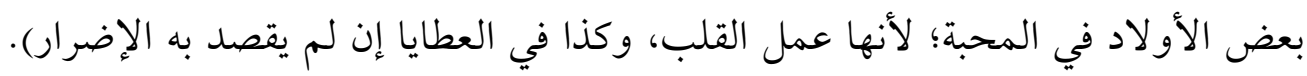

$$
\text { حاشية ابن عابدين (797/0) (197). }
$$

(0) قال القاضي عبد الوهاب: (يجوز أن ينحل الرجل بعض ولده الده ماله، ويكره أن ينحله $=$ 


\section{استدلَّ أصحابُ القول الأول القائلون بالتحريم، بما يلي:}

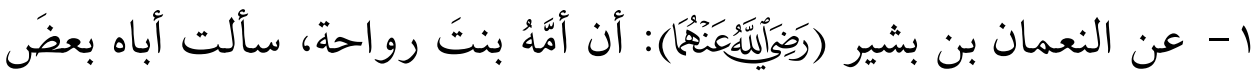

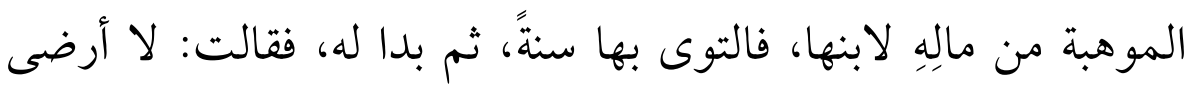

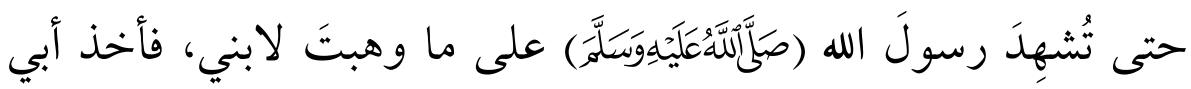

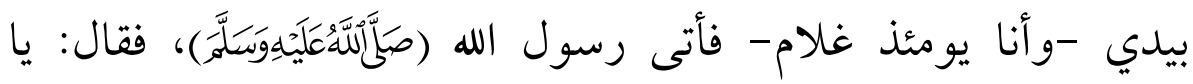

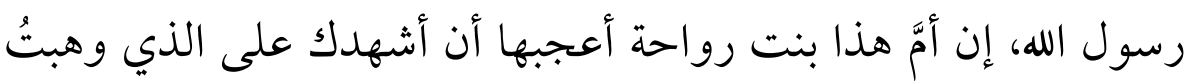

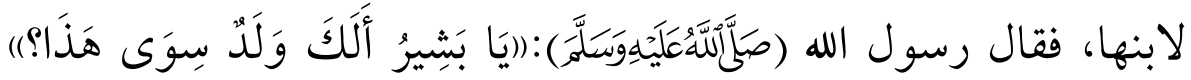

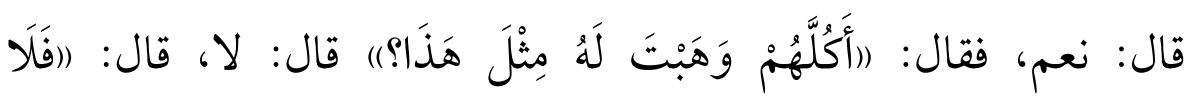

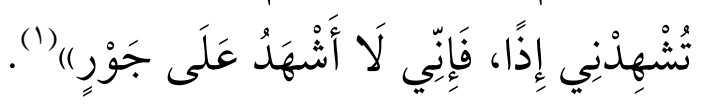

جميع ماله، وأيّ ذلك فعل نفذ إذا كان في الصحة). الإشراف على نكت مسائل

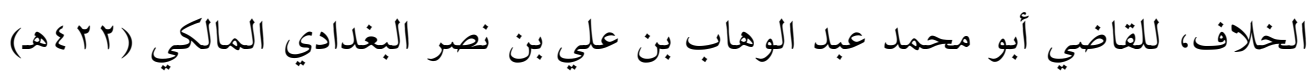

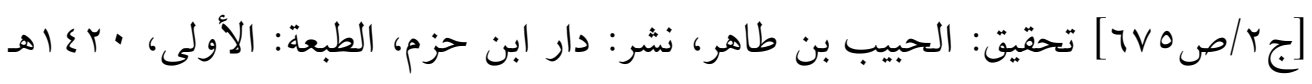

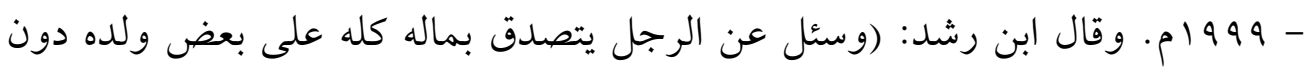

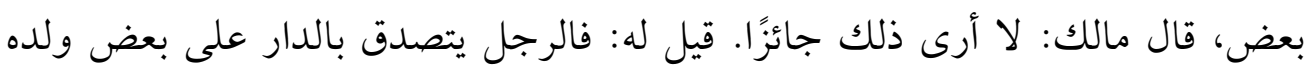

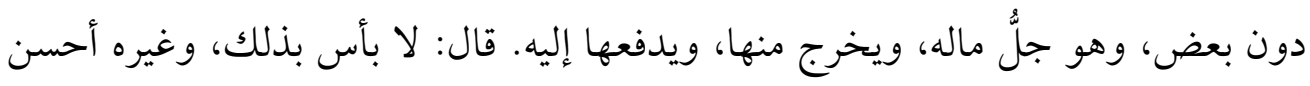

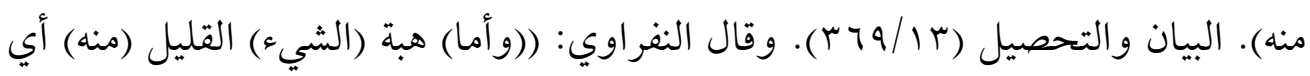

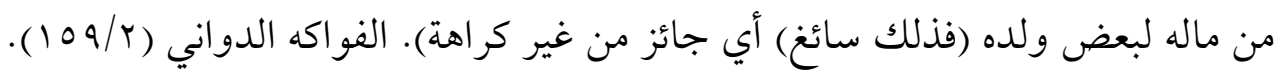

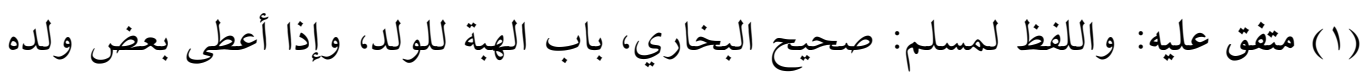

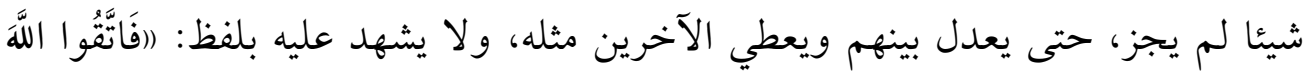

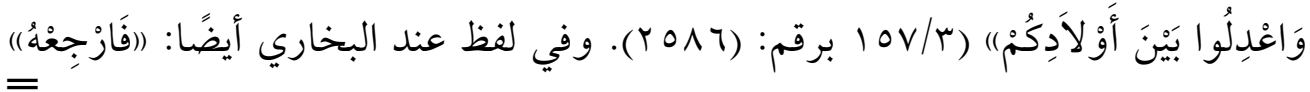


وهو حديث متفق على صحته، وإن كان قد اختلف في ألفاظه (1).

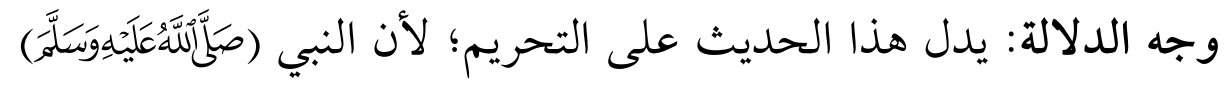

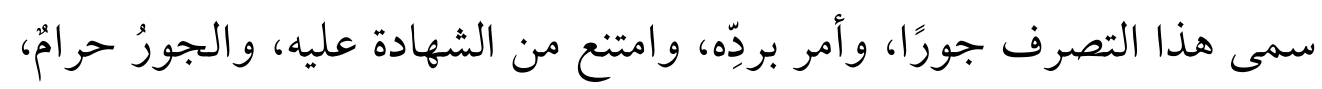
والأمر يقتضي الوجوبـ(r).

قال القرطبي: (وما كان جورًا وغير حق، فهو باطل، لا يجوز) (“).

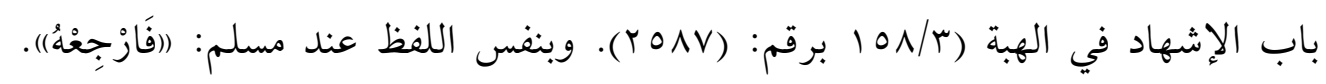

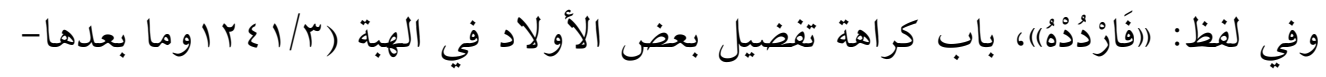

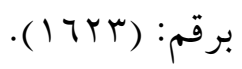

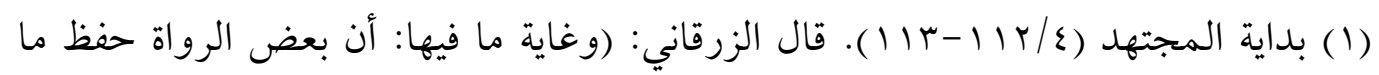

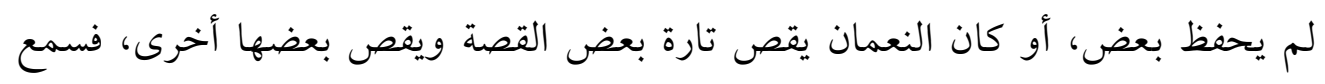

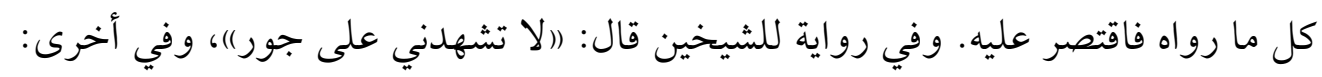

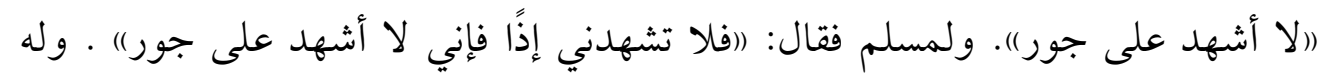

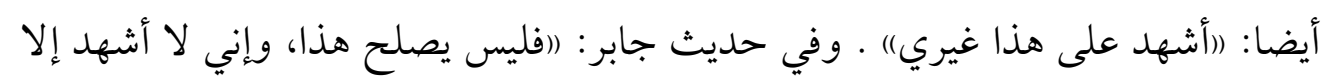

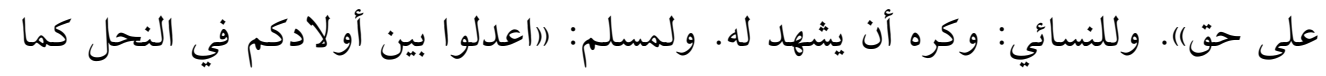

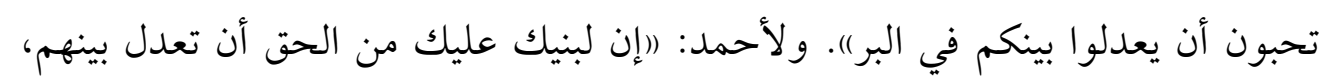

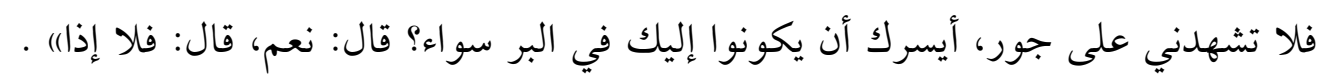

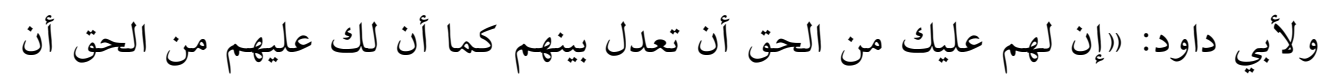

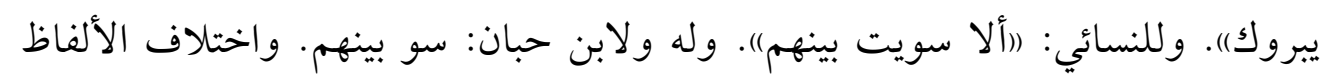
في هذه القصة الواحدة يرجع إلى معنى واحد). شرح الزرقاني على الموطأ (ع/AY).

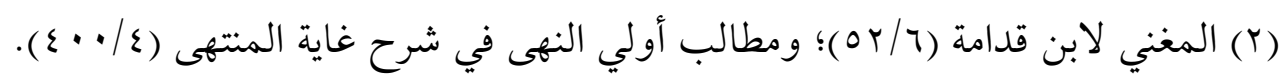

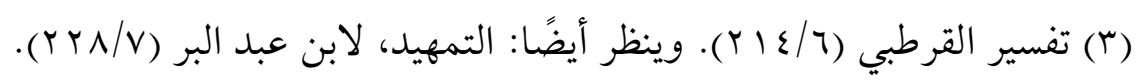




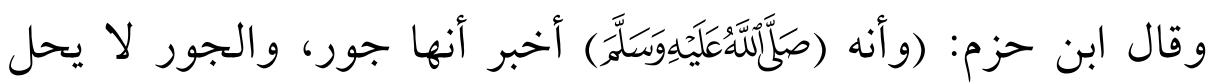

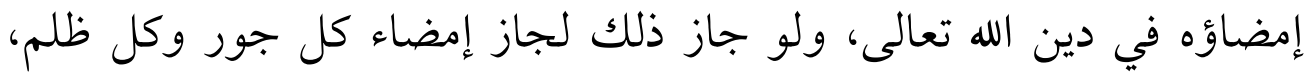
وهذا هدم الإسلام جهارًا) (1).

واعتُرض: بأن الجور هو: الميل عن الاعتدال، والمكروه أيضًا جور،

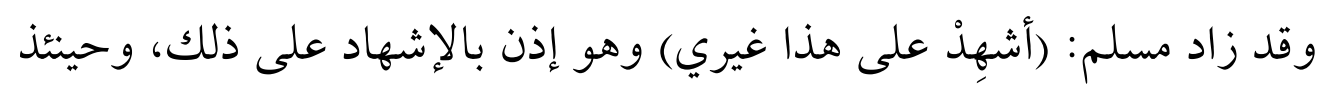

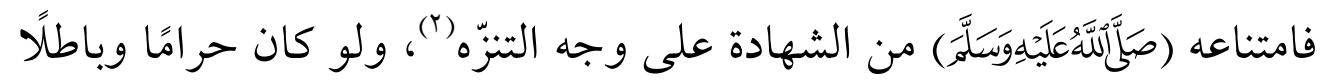

لما قال هذا (").

وأجاب ابن دقيق العيد: بأن الصيغة وإن كان ظاهرها الإذن بهذا، إلا

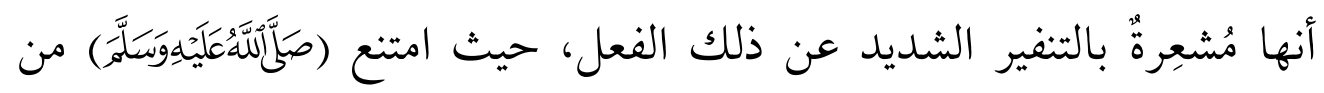

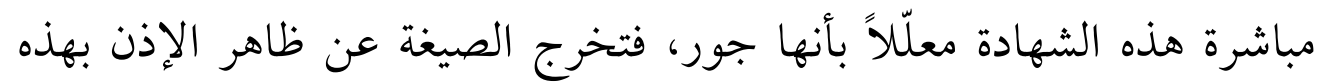
القرائن، وقد استعملو ا مثل هذا اللفظ في مقصود التنفير (s). وأجاب أيضًا الحافظ ابن حجر قائلا: (وزعم بعضهم أن معنى قوله: (لا لا

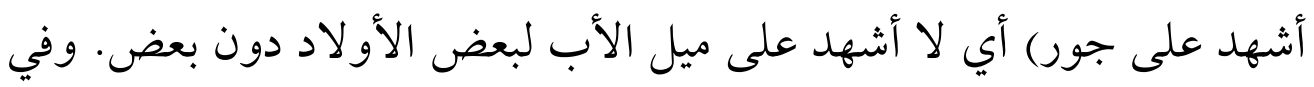
(1) (1) المحلى بالآثار / لابن حزم الظاهري (1) (9/1).

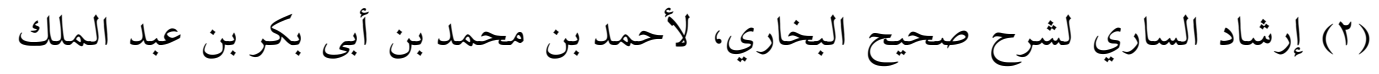

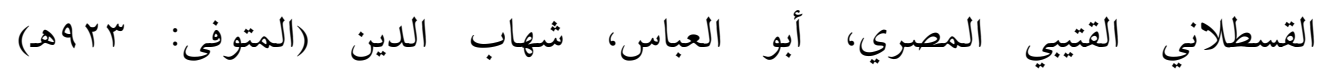

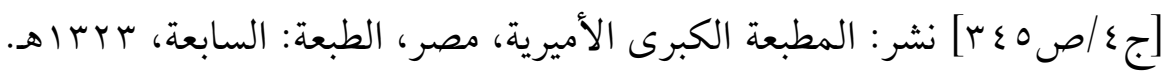

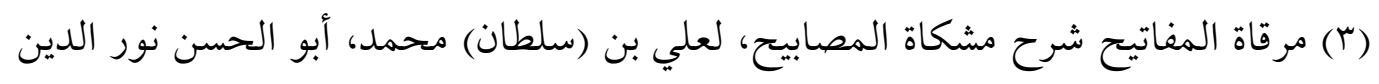

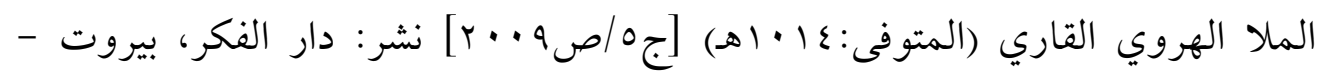

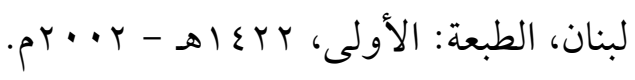

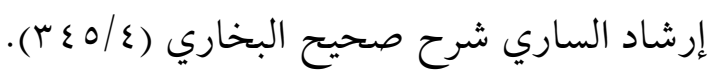


هذا نظرّ لا يخفى، ويردّه قوله في الرواية: (لا أشهد إلا على الحق) (1).

وأجاب القرطبي كذلك بقوله: (وقوله: (أشهد على هذا غيري) ليس إذنًا

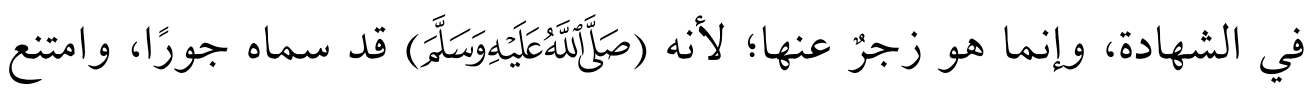
من الشهادة فيه، فلا يمكن أن يشهد أحدٌ من المسلمين في ذلك بوجه) (r). ץ- ولأن الحديث روي بألفاظ كثيرة تدل على وجوب التسوية، وتحريم تفضيل بعض الأبناء - في العطية- دون بعضي:

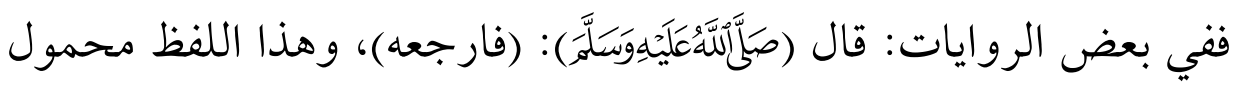

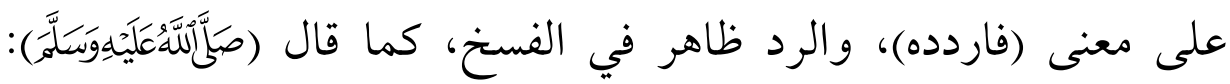
(من عمل عملاً ليس عليه أمرنا فهو رد) أي مردود مفسوخ. وهذا كله

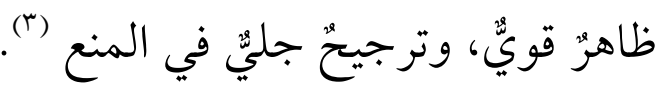
واعتّر ضِ بأمرين:

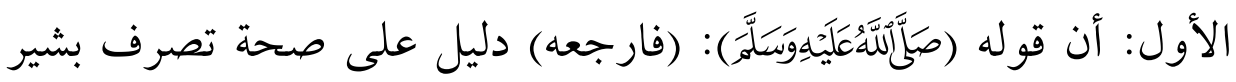

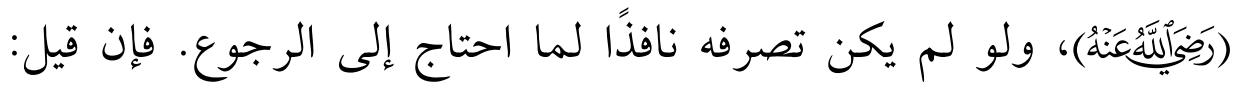

(1) فتح الباري شرح صحيح البخاري، لأحمد بن علي بن حجر أبو الفضل العسقلاني

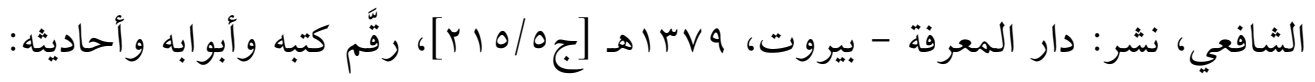
محمد فؤاد عبد الباقي، قام بإخراجه وصححه وأشرف على طبعه: محب الدين الخطيب.

$$
\begin{aligned}
& \text { (Y) تفسير القرطبي (T/ ا ا ). } \\
& \text { (r) المرجع السابق نفسه. }
\end{aligned}
$$


قاله تهديدًا. قلنا: الأصل خلافه (1).

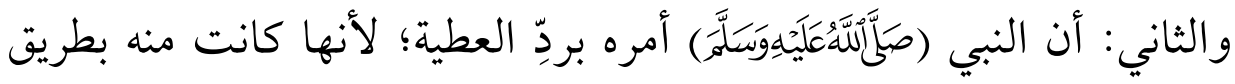
الوصية بعد موته، وإنما تجب التسوية في الوصية بعد الموت، فأما في الهبة في الصحة فلا؛ ويدل لذلك ما ورد في تفضيل بعض الصحابة

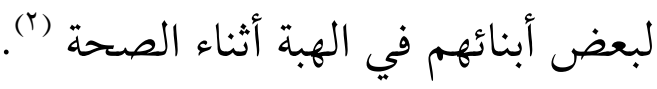

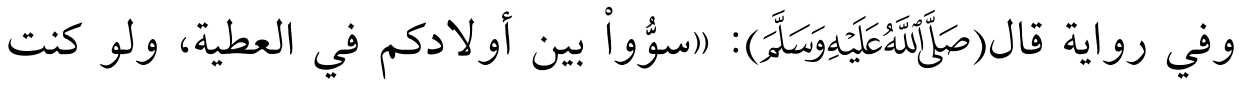
مؤثرًا أحدًا لآثرت النساء على الرجال). فالعدل من حقوق الأولاد في

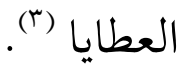
وفي رواية: (فاتقوا الله، واعدلوا بين أولادكم)، قال: فرجع أبي فرد تلك

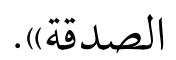

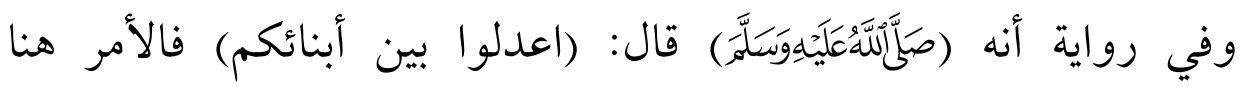

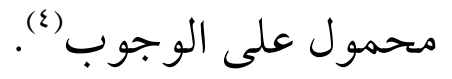
واعتُرض: بأن قصة النعمان بن بشير هذه قد رويت بألفاظ مختلفة، أكثرها يدل على أن ذلك على سبيل الندب لا على الإيجاب، منها:

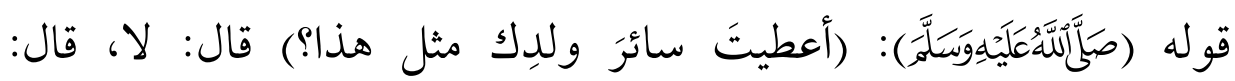
(فاتقوا الله، واعدلوا بين أولادكم) قال: فرجع، فرد عطيته، فلم يذكر في

$$
\begin{aligned}
& \text { (1) مرقاة المفاتيح شرح مشكاة المصابيح (9/0 + . (Y). }
\end{aligned}
$$

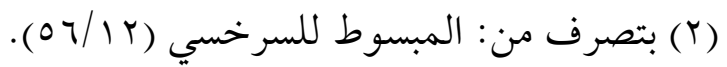

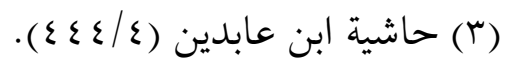

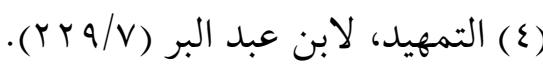




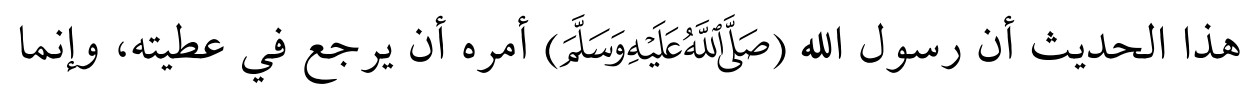
فيه (رجع، فردَّ عطيتَه).

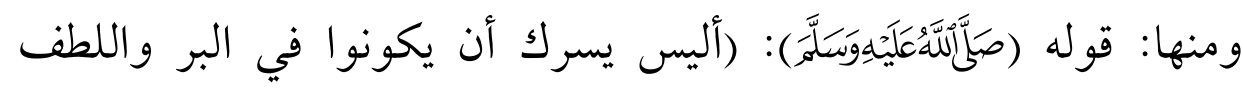

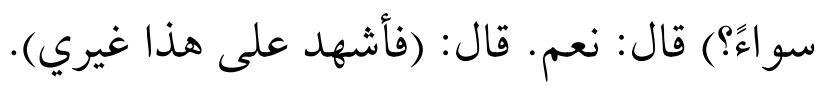

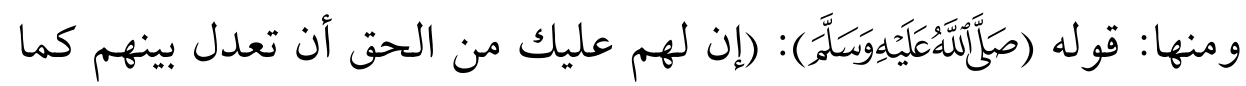
أن لك عليهم من الحق أن يبروك).

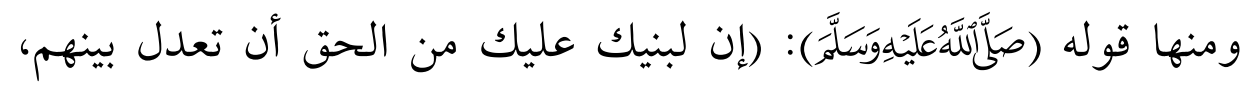
فلا تشهدني على جور).

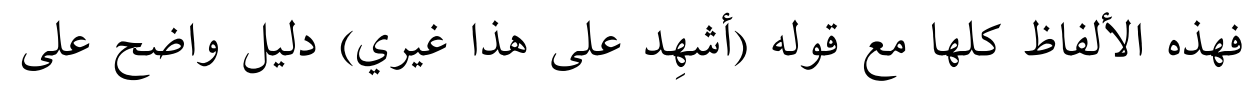

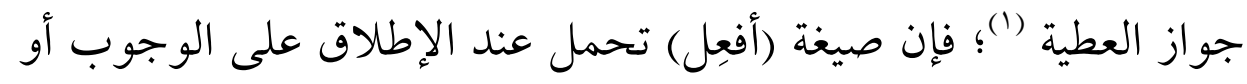

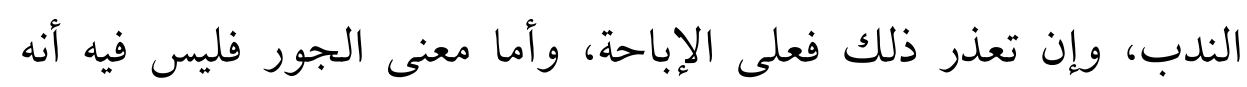

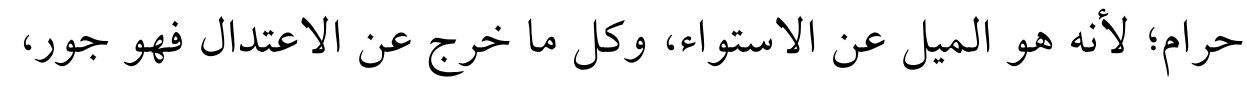

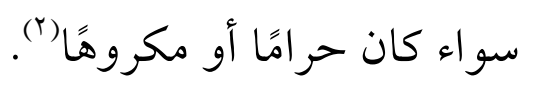

فإن قيل: بأن هناك روايات أخرى للحديث جاء فيها التصريح بأنه

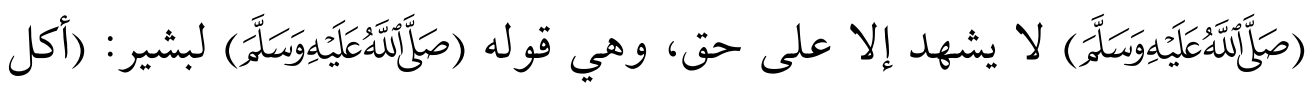

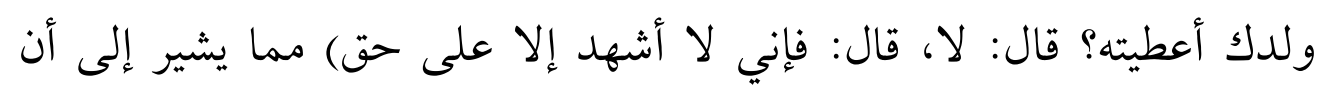

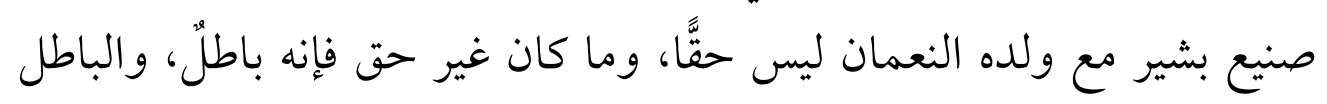
حرامُ.

$$
\begin{aligned}
& \text { (1) بتصرف واختصار من: التمهيد، لابن عبد البر (V/ • r وما بعدها). }
\end{aligned}
$$

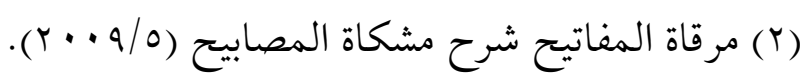


فيحتمل أن لا يكون مخالفًا لما تقدم؛ لاحتماله أن يكون أراد الحق

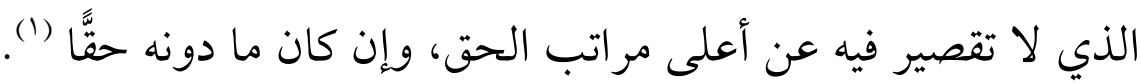

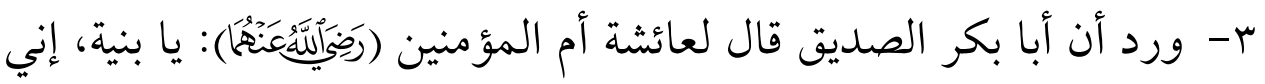

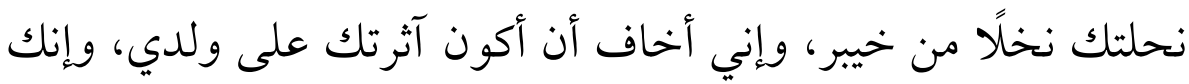

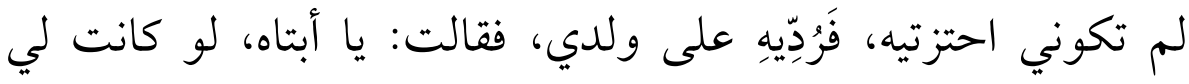
خيبر بجدادها ذهبًا لرددتُها (r).

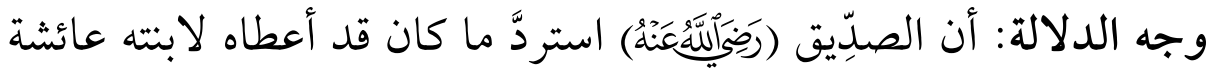

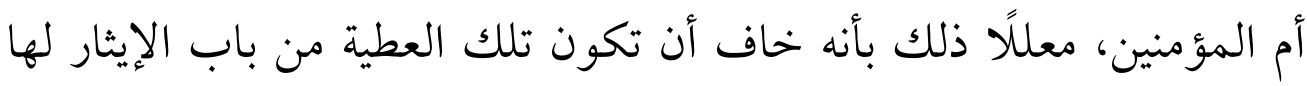
وتمييزها عن بقية أبنائه، ولو كانت العطية جائزة لاستبقاها وما استردها.

وقد يُعترض: بأن القصة وردت بروايات أخرى؛ منها: أن عائشة

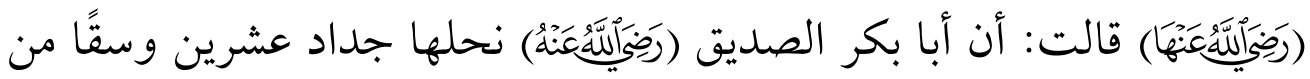
ماله بالغابة، فلما حضرته الوفاة، قال: والله يا بنية، ما من أحدٍ من الناس أحب الحبال

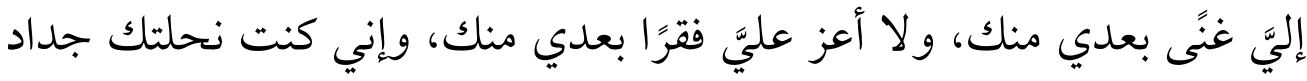

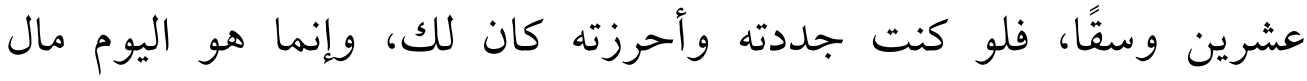

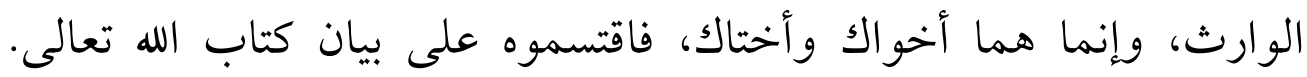

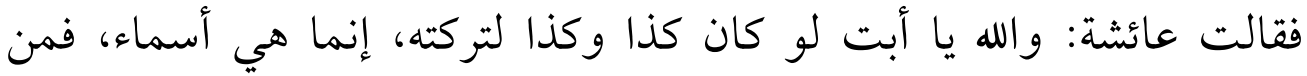
الأخرى؟ فقال: ذو بطن بنت خارجة، أراها جارية.

ثم إن الحديث يقتضي أنه خصَّها بالنحلة دون سائر أخواتها، ورأى

$$
\begin{aligned}
& \text { (1) التمهيد، لابن عبد البر (Y Y Y ( ) . } \\
& \text { (بالمحلى، لابن حزم (1/7 (9). }
\end{aligned}
$$


ذلك جائزًا له (1). فالحديث دليل عليكم لا لكم.

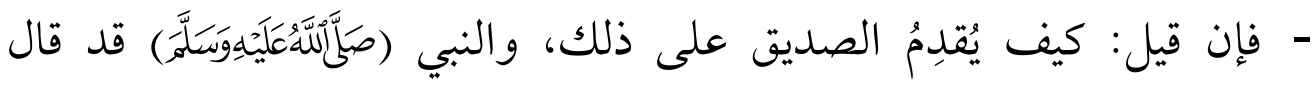

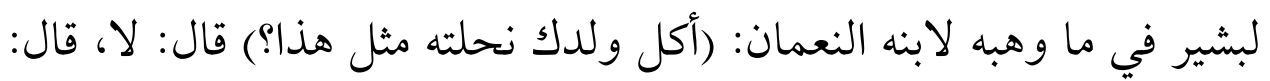
أرجعه.

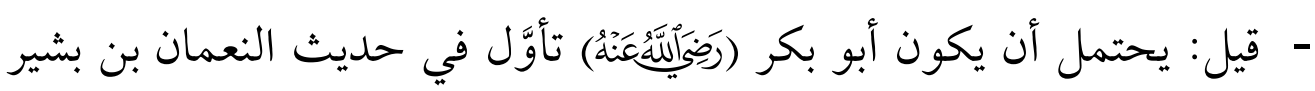

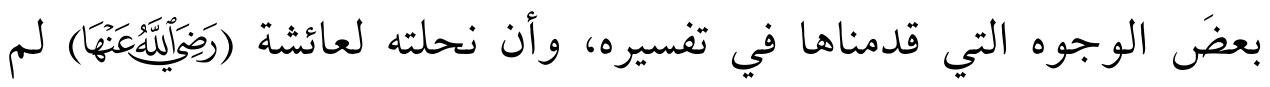
تكن على شيء من ذلك، وإنما كان لفضل عائشة على سائر إخوتها،

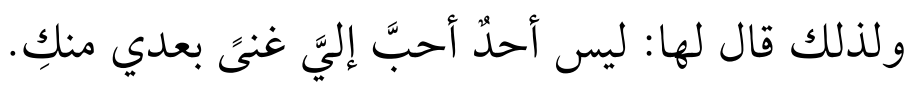

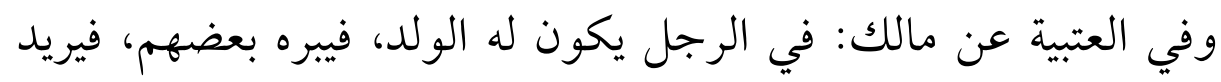
أن يعطيه عطية من ماله دون غيره: لا بأس بذلك (r).

ع - وقد ورد عدد من الآثار يفيد حرمة التفضيل، منها (r):

عن مجاهد قال: من نحل ولثًا له نحلاً دون بنيه، فمات، فهو ميراث.

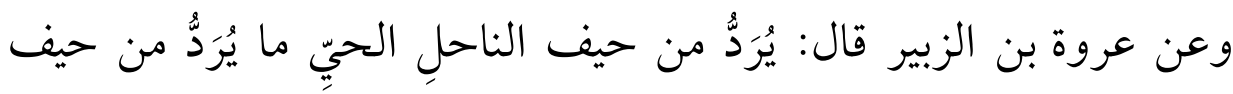
الميت من وصيته. وعن طاووس أنه قال في الولد: لا يفضل أحد على أحد بشعرة، النحل

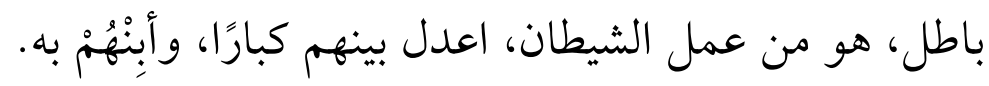

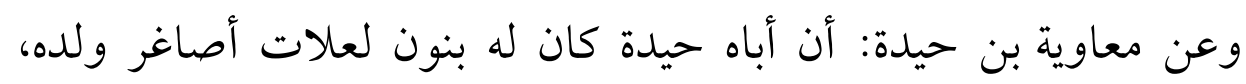

$$
\begin{aligned}
& \text { (1) المنتقى شرح الموطأ (7/9r/ ) بتصرف. }
\end{aligned}
$$

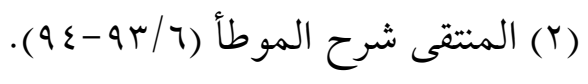

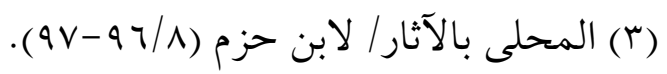


وكان له مالٌ كثيرٌ، فجعله لبني علة واحدة، فخرج ابنه معاوية حتى قدم على عثمان بن عفان، فأخبره بذلك، فخيَّ عثمان الشيخَ بين أن يردَّ إليه ماله وبين أن يوزعه بينهم؟ فارتدَّ ماله، فلما مات تركه الأكابر للإخوتهم. وعن زهير بن نافع قال: سألت عطاء بن أبي رباح، فقلت: أردتُ أن أَفْضِّلَ بعض وعن رهير بن ولدي في نحل أنحله؟ فقال: لا، وأبى إباءً شديدًا وقال: سوّ

بينهم.

قال ابن حزم: (فهؤلاء أبو بكر، وعمر، وعثمان، وقيس بن سعد، وعائشة

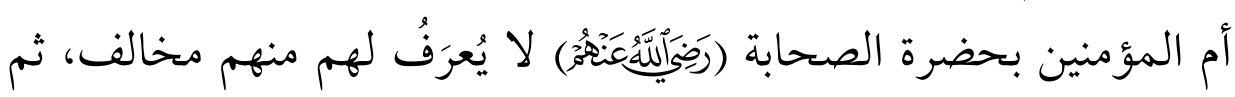
مجاهد، وطاووس، وعطاء، وعروة، وابن جريج - وهو قول النخعي، والشعبي، وشريح، وعبد الله بن شداد بن الهاد، وابن شبرمة، وسفيان الثوري، وأحمد بن حنبل، وإسحاق بن راهويه، وأبي سليمان، وجميع (1) أصحابنا)

0- روى سفيان بن عيينة، عن ابن أبي نجيح، عن طاووس قال: كان إذا سألوه عن الرجل يفضل بعض ولده على بعض، يقرأ هذه الآية:

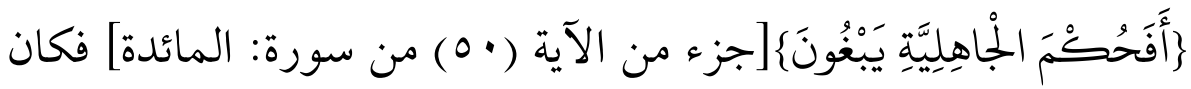
طاووس يقول: ليس لأحد أن يفضل بعض ولده على بعض (r). 7- ولأن تفضيل بعضهم يورث بينهم العداوة والبغضاء وقطيعة الرحم،

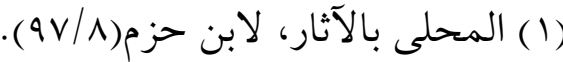

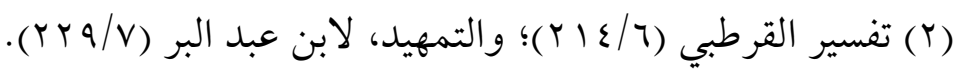




\section{فمُنع منه، كتزويج المرأة على عمتها أو خالتها(').}

V- ولأن محاباة بعض الأبناء ظلم وجور؛ وقد نهى عن ذلك الله ورسوله،

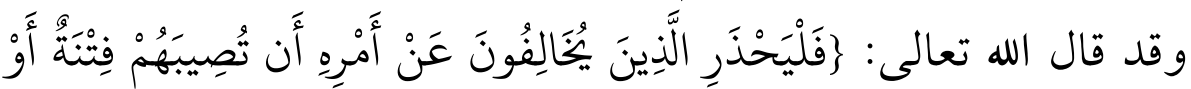

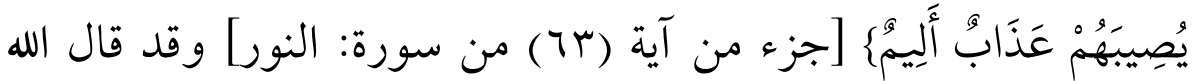

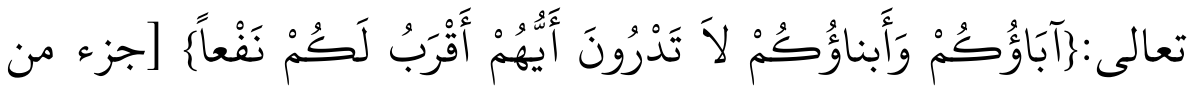
الآية (1 ا) من سورة: النساء] فالعبد لا يدري، ولكن الله يدري ذلك؛ فقسم حيث توجد المصلحة، وتتوفر المنفعة، وهذا يتنافى مع ما يعمله بعضُ الجُهُّال؛ من إيثار بعض أبنائه بماله، وحرمان البعض الآخر؛ مما يوجب البغضاء والشحناء، ويؤدي إلى ارتكاب الجرائم، ووخيم

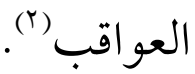

^- ولأن إعطاء بعضهم دون بعض يؤدى إلى قطع الرحم والعقوق،

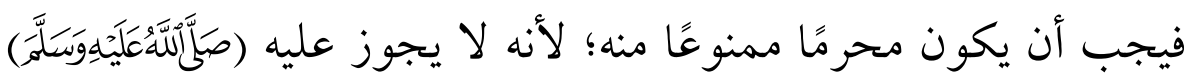
أن يحث على صلة الرحم ويجيز ما يؤدى إلى قطعها" آ. ه- من باب مقدمة الواجب؛ لأن قطع الرحم والعقوق محرمان، فما يؤدي

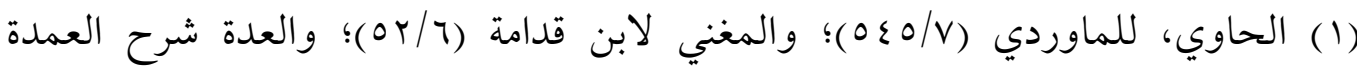
(ص 17 ( 17 .

(r) بتصرف من: أوضح التفاسير، لمحمد محمد عبد اللطيف بن الخطيب (المتوفى:

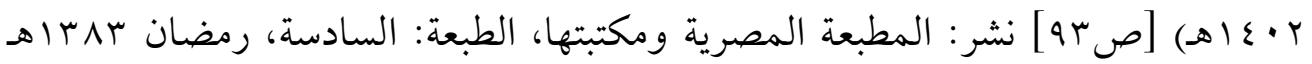

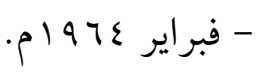
(r) شرح صحيح البخاري، لابن بطال (9/V) ). 
إليهما يكون محرمًا، و التفضيل مما يؤدي إليهما (1).

واعتُرض: بأن الأصلَ أن للإنسان حق التصرف في ماله مطلقًا (؟).

\section{وأجيب بجوابين:}

الأول: أن الأصلَ الكليَّ والواقعةَ المعينةَ المخالفةَ لذلك الأصل لا تعارض بينهما، كالعموم والخصوص، وفي الأصول: أن الصحيحَ بناءُ العامِّ على الخاصِّ.

والثاني: أنه ينشأ عن ذلك التصرف: العقوقُ الذي هو من أكبر الكبائر،

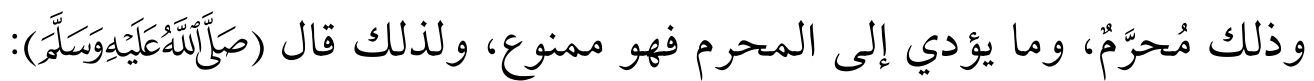

$$
\text { (اتقوا الله، واعدلوا بين أولادكم). }
$$

\section{أدلة الإمام مالك على القول بحرمة نحل جميع المال لبعض الأبناء:}

1 - حديث النعمان بن بشير: أن أباه بشيرًا أتى به إلى رسول الله

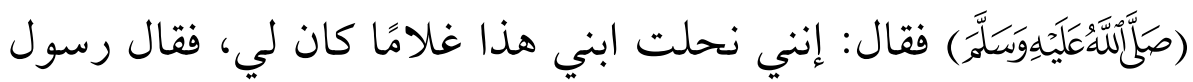

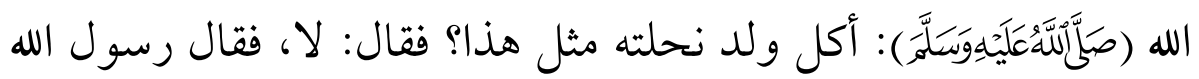

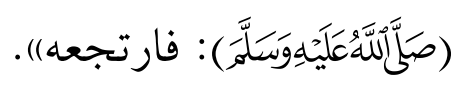

$$
\text { فتح الباري، لابن حجر (Y) (Y) (Y) (ب). }
$$

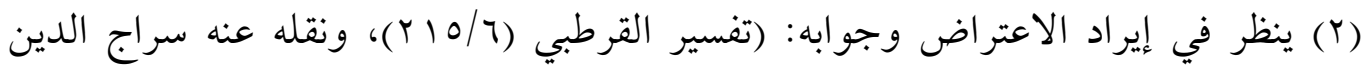

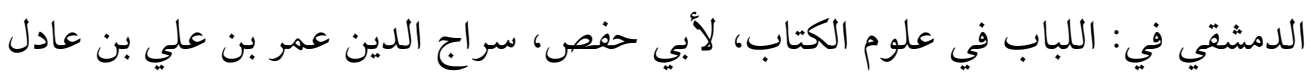

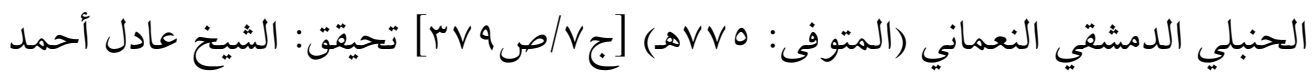

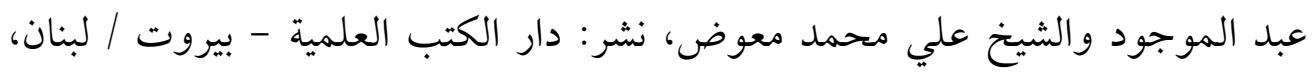

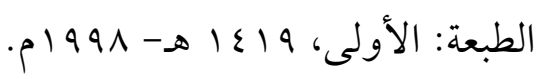


فحمل الإمام مالك الأمرَ بالارتجاع في الحديث على الوجوب -كما

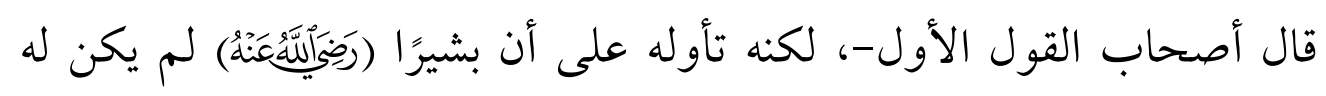

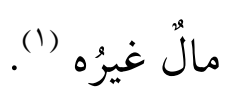

قال ابن بطال: (وقد قال مالك: لم يكن لبشير مالٌ غير الغلام الذى

نحله ابنه) (r)

r- ولأن الفرق بين هبة الرجل بعض ماله لبعض ولده وبين هبة الرجل

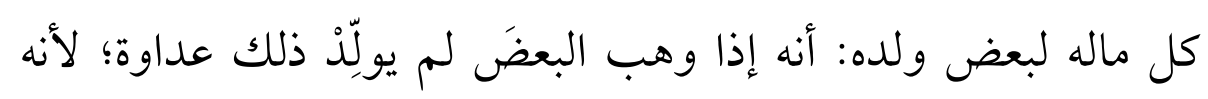

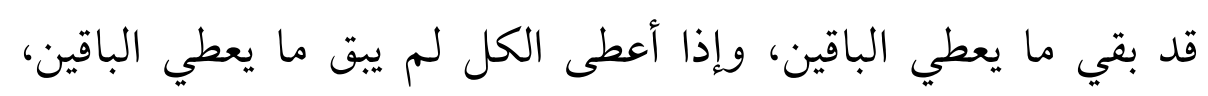

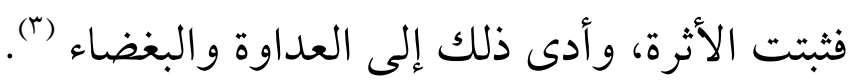
ب- ولأنه إذا لم يستبِق من مالِه ما يكفيه، فهو بمنزلة ما لو تصدَّق بماله جميعه (q)

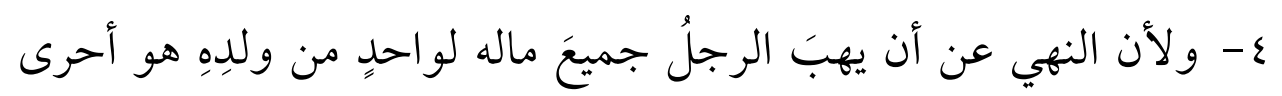

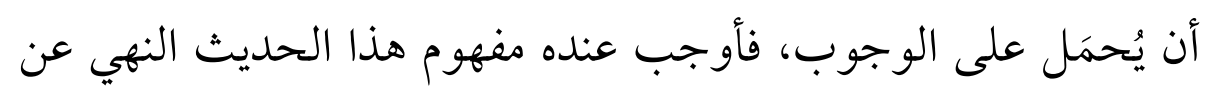

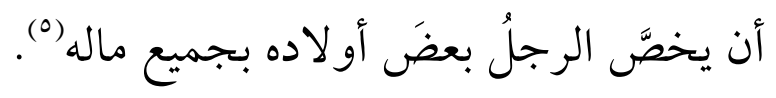

$$
\begin{aligned}
& \text { (1) البيان والتحصيل (r (rV). }
\end{aligned}
$$

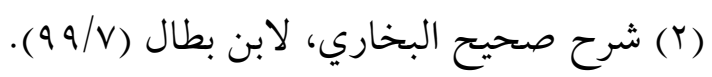

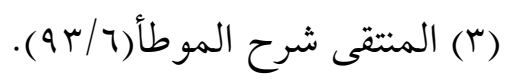

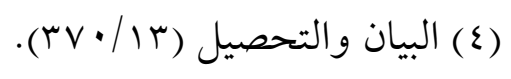

$$
\begin{aligned}
& \text { (0) بداية المجتهد (ع/r/ (1) ). }
\end{aligned}
$$




\section{واستدل أصحابُ القول الثاني، القائلون بكراهة التفضيل، بما يلي:}

1- حديث النعمان بن بشير الذي استدل به أصحابُ القول الأول القائلون

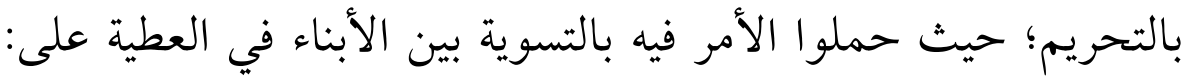

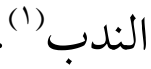

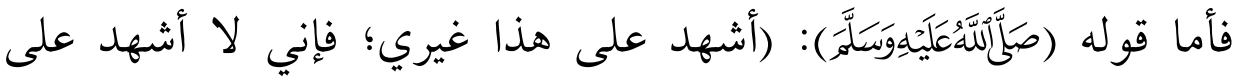
جور) فإنه لا يدل على التحريم؛ قال ابن حجر الهيتمي: (ولو كان محرمًا

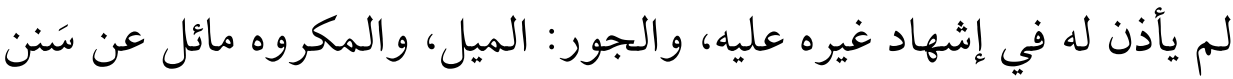

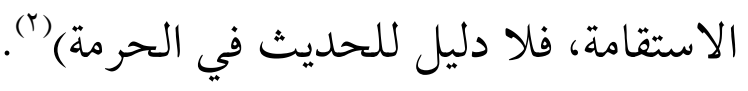

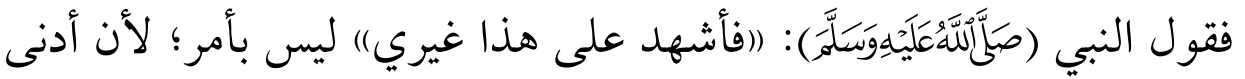

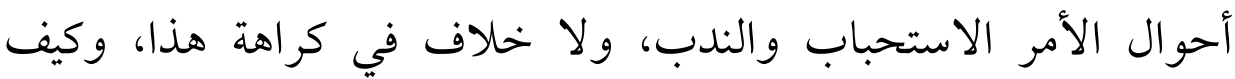

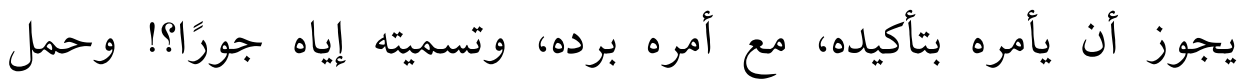

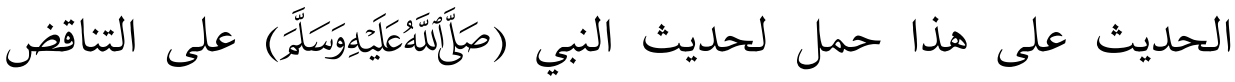

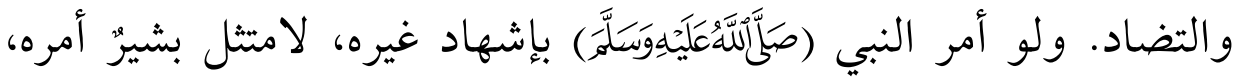

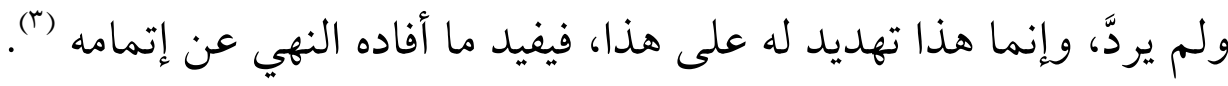

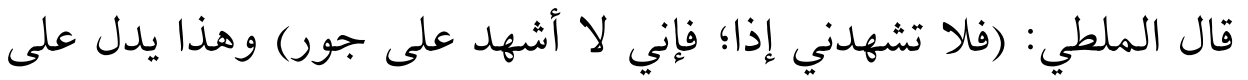

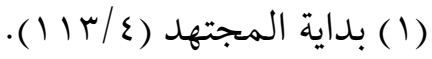

(Y) الفتاوى الفقهية الكبرى (ع / (Y). (r) المغني لابن قدامة (T/7) 
أن قوله: (أشهد على هذا غيري) ليس على الإباحة، بل هو تقريع)('). قال ابن حجر، وشهاب الدين الرملي: (فأمره بإشهاد غيره صريح في الجواز، وأن تسميته جورًا باعتبار ما فيه من عدم العدل المطلوب) (r).

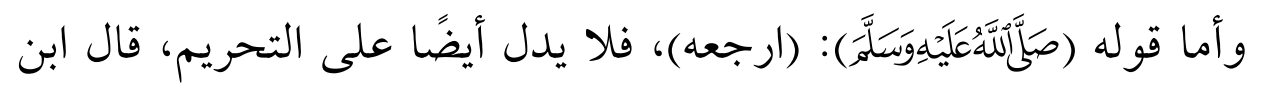

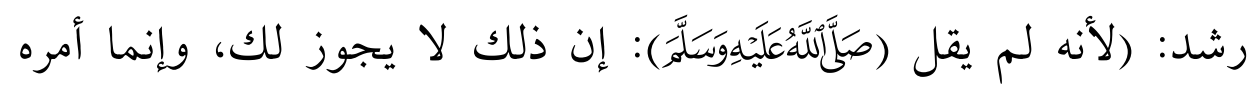
بالارتجاع؛ لما كره له من تفضيل بعض ولده على بعض؛ مخافة أن يكون

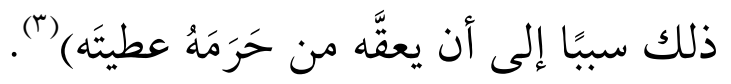

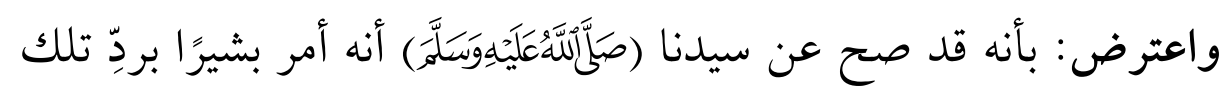

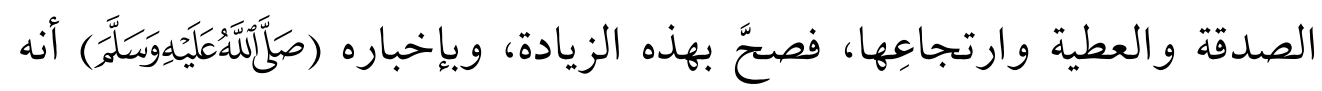

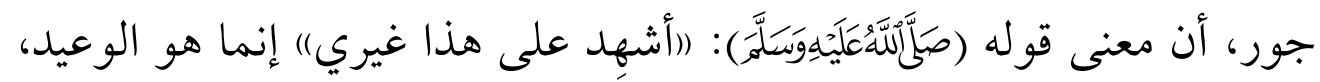

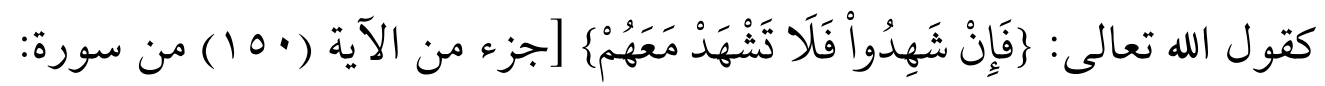
الأنعام] ليس على إباحة الشهادة على الجور والباطل، لكن كما قال تعالى:

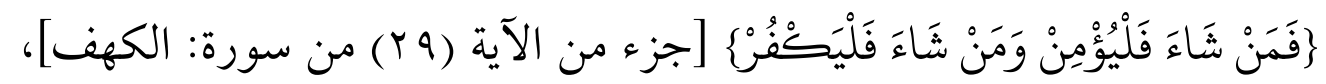

(1) المعتصر من المختصر من مشكل الآثار، ليوسف بن موسى بن محمد، أبو المحاسن

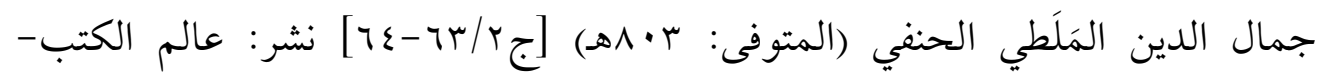
بيروت.

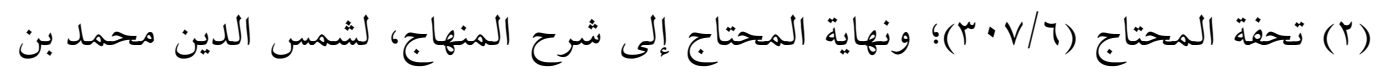

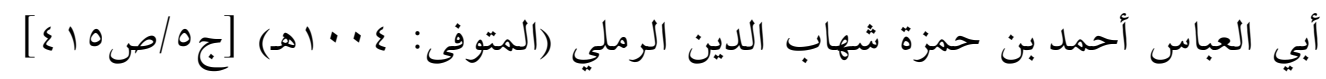

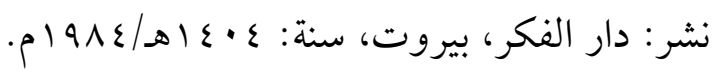

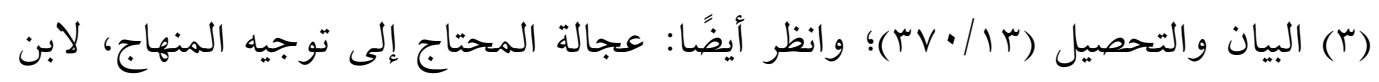

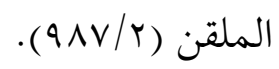




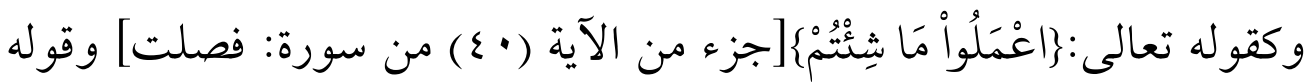

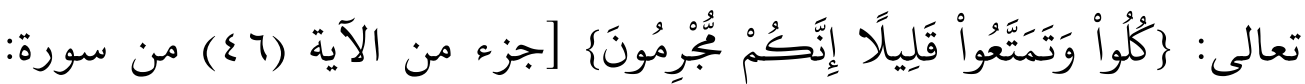

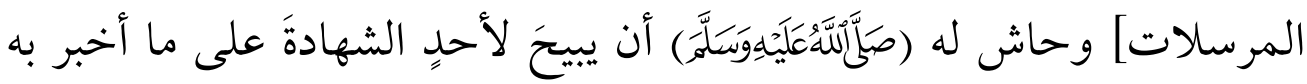
هو أنه جور، وأن يمضيه ولا يرده، هذا ما لا يجيزه مسلم، ويكفي من هذا أن نقول: تلك العطية والصدقة أحق جائز هي أم باطل غير جائز؟ ولا سبيل إلى

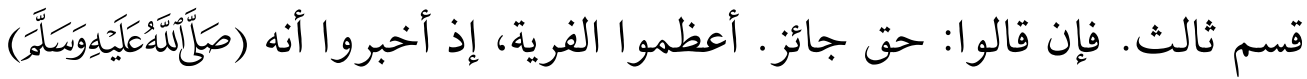
أبى أن يشهد على الحق- وهو الذي أتانا عن ربنا تعالى بقوله

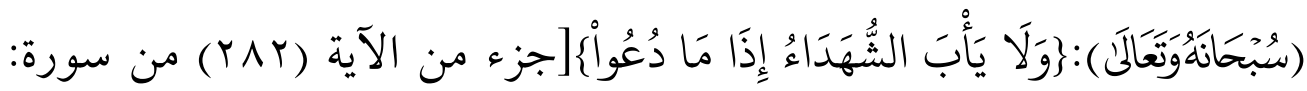

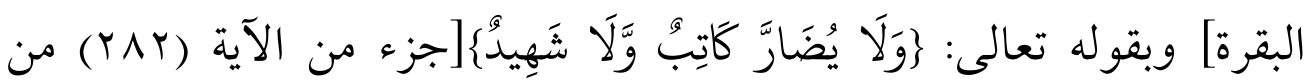
سورة: البقرة]، وإن قالوا: إنها باطل غير جائز، أعظموا الفرية، إذ أخبروا أن

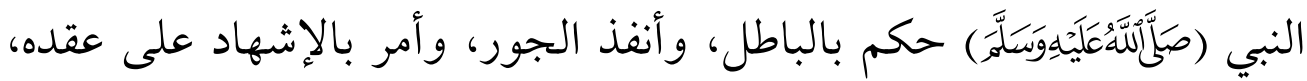
وكلا القولين مخرج إلى الكفر بلا مرية، ولا بد من أحدهما)('). r- إن الأمر في الحديث بالتسوية محمولٌ على الاستحباب، وليس محمو لاً على الوجوب، ويدل على ذلك وجوه (r)": الأول: أن الموهوب للنعمان كان جميع مال والده، فلذلك منعه، فليس

$$
\text { المحلى بالآثار، لابن حزم الظاهري (1/ · • (1 - • (1). }
$$

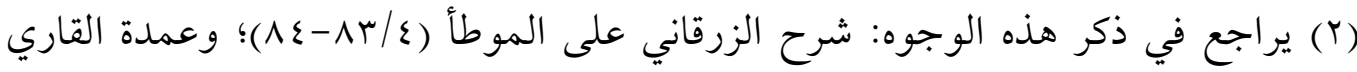

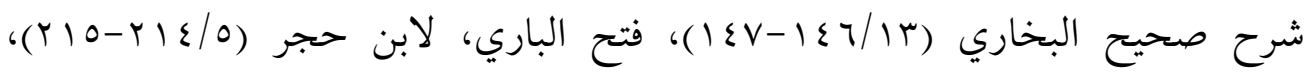
وشرح سنن النسائي المسمى ((ذخيرة العقبى في شرح المجتبى)، لمحمد بن علي بن

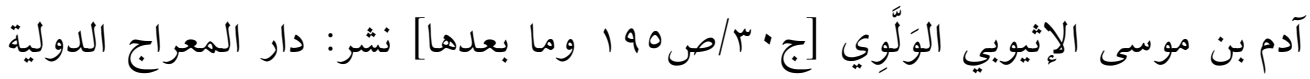

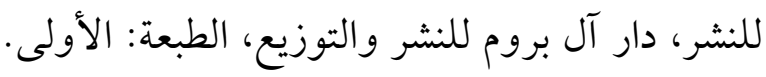


فيه حجة على منع التفضيل. حكاه ابن عبد البر عن مالك.

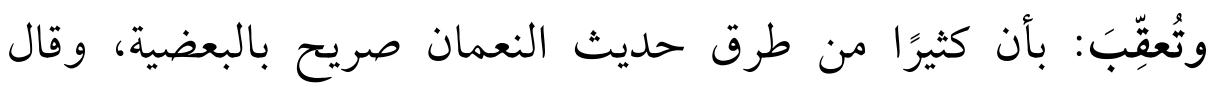

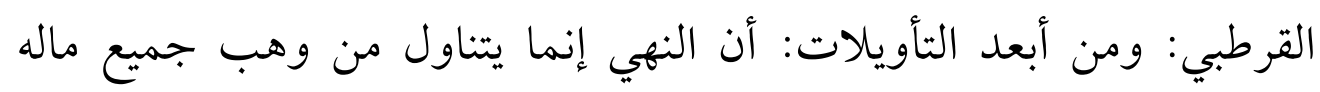

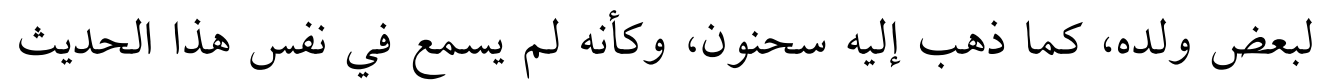

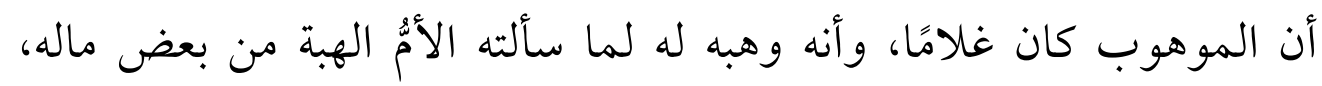
قال: وهذا يُعلم منه على القطع أنه كان له مال غيره.

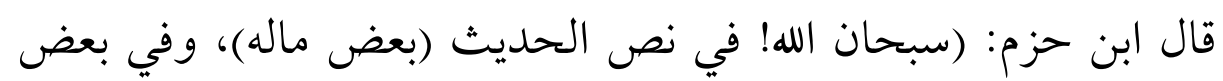
الروايات الثابتة (بعض الموهبة من ماله).

ومعنى كلامه رحمه الله: أن ادعاء أن بشيرًا وَهَبَ النعمانَ كلَّ ماله،

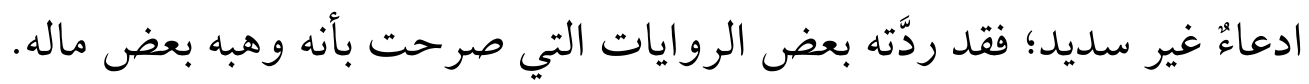
• الثاني: أن العطية المذكورة لم تتنجز، وإنما جاء بشير والد النعمان

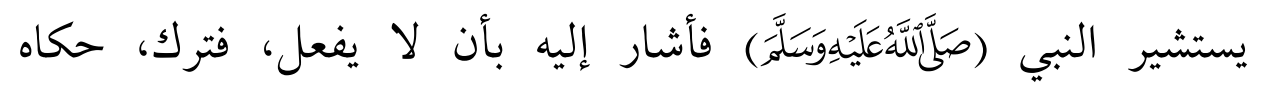
الطحاوي. - قال بعضهم: وفي أكثر طرق الحديث ما ينابذه.

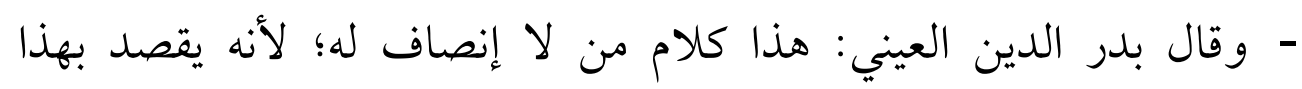

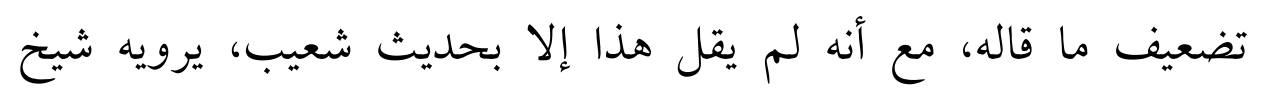

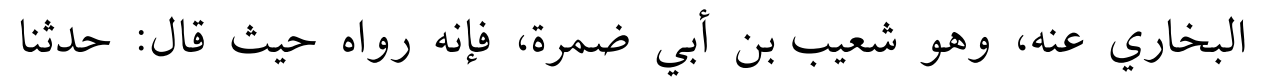

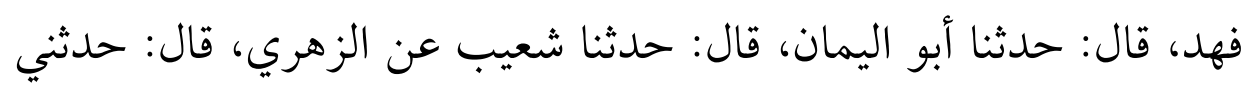

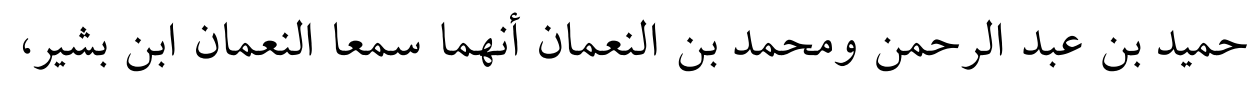

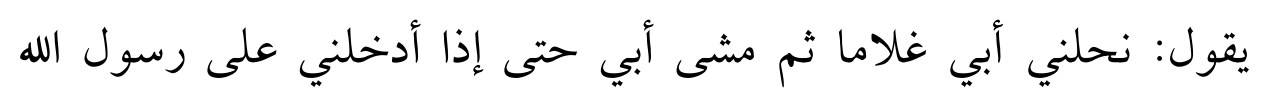




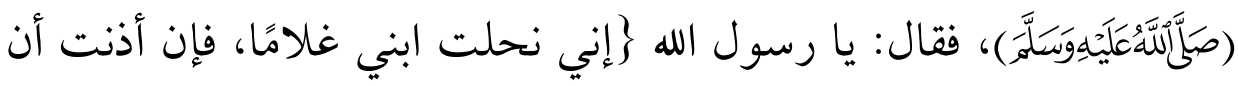

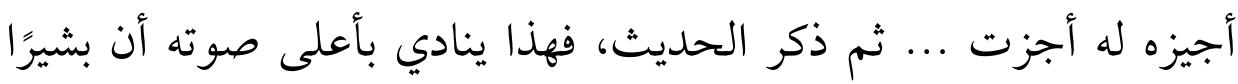

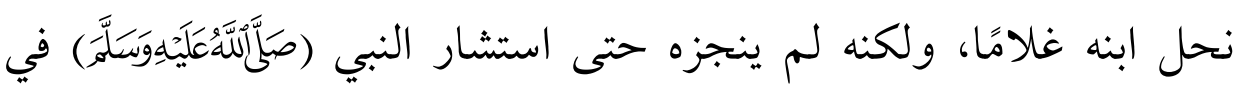

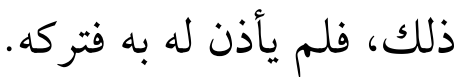

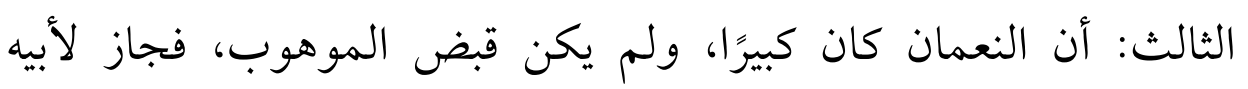
الرجوع. ذكره الطحاوي أيضا. - قال بعضهم: وهو خلاف ما في أكثر طرق الحديث أيضا، قوله: أرجعه، أرها.

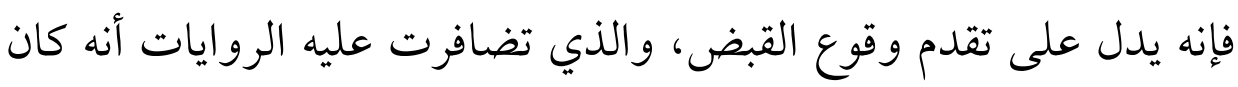

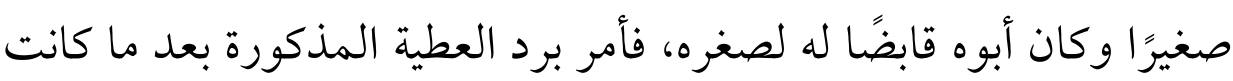

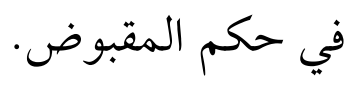
- وقال بدر الدين العيني: هذا أيضا طعن في كلام الطحاوي من غير وجه

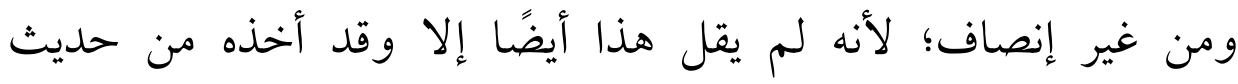

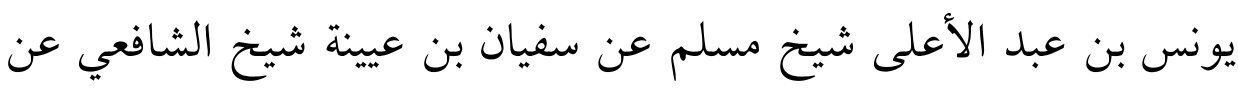

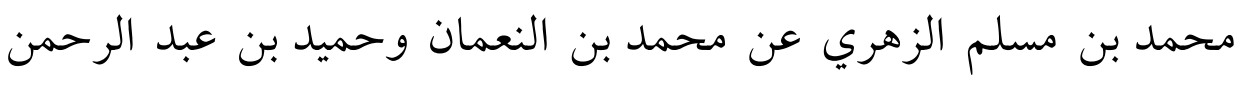

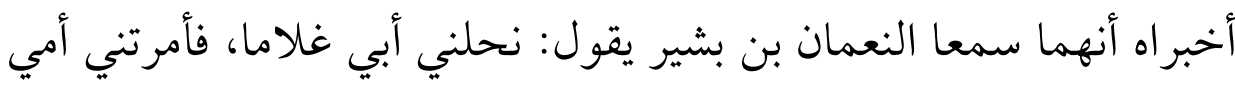

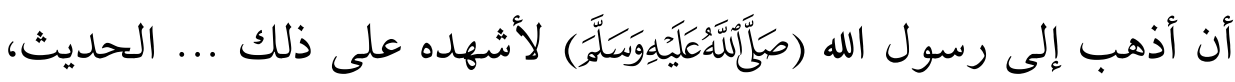

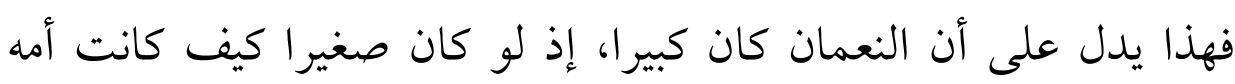

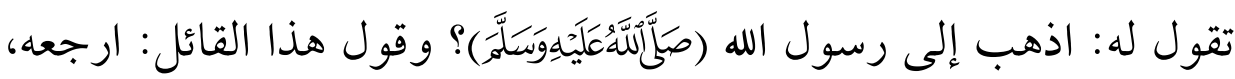

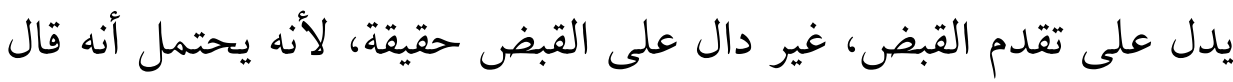

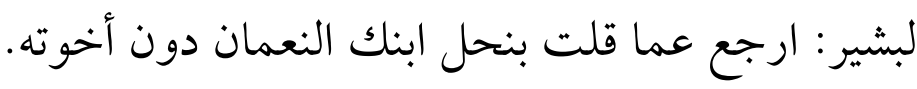

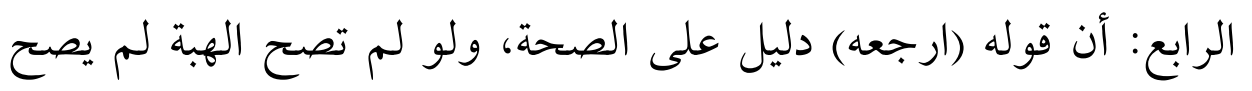


الرجوع، وإنما أمره بالرجوع؛ لأن للو الد أن يرجع فيما وهبه لولده - وإن كان الأفضل خلاف ذلك- لكن استحباب التسوية رجح على ذلك،

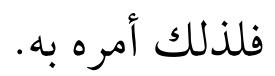

- وفي الاحتجاج بذلك نظر، والذي يظهر أن معنى قوله: (ارجعه) أي لا تمض الهبة المذكورة، ولا يلزم من ذلك تقدم صحة الهبة. هالخامس: أن قوله: (أشهِد على هذا غيري) إذن بالإشهاد على ذلك، وإنما امتنع من ذلك لكونه الإمام، وكأنه قال: لا أشهد؛ لأن الإمام ليس من شأنه أن يشهد، وإنما من شأنه أن يحكم، حكاه الطحاويّ أيضًا، وارتضاه ابن القصّمار.

- وتُعُقِب بأنه لا يلزم من كون الإمام ليس من شأنه أن يشهد أن يمتنع من

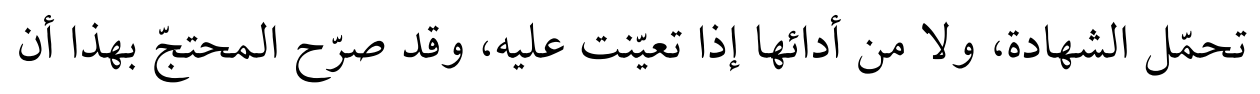
الإمام إذا شهد عند بعض نوَّابه جاز. - وأما قوله: إن قوله: "أشهِذْ" صيغة إذن، فليس كذلك، بل هو للتوبيخ لما يدلّ عليه بقيّة ألفاظ الحديث، وبذلك صرح الجمهور في هذا الموضع. - وقال ابن حبّان: قوله: "أَشهِد" صيغة أمر، والمراد نفي الجواز، وهو كقوله لعائشة: "اشترطي لهم الولاء" انتهى. هادس: التمسك بقوله (ألا سويت بينهم) على أن المراد بالأمر: الاستحباب، وبالنهي: التنزيه. - وهذا جيد، لو لا ورود تلك الألفاظ الزائدة على هذه اللفظة، ولا سيما أن تلك الرواية بعينها وردت بصيغة الأمر أيضا حيث قال (سوّ بينهم).

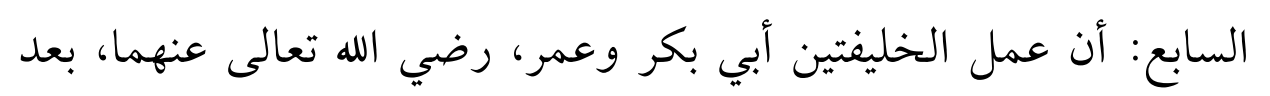




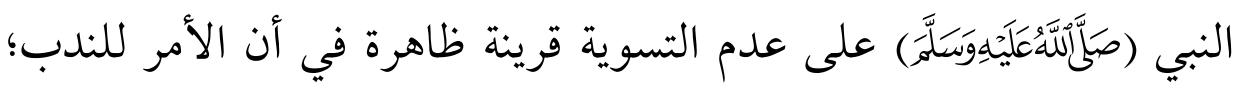

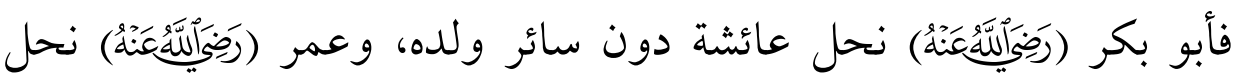
ابنه عاصمًا دون سائر أولاده. ذكره الطحاوي وغيره. - وقد أجاب عروة عن قصة عائشة: بأن إخوتها كانوا راضين بذلك، ويجاب بمثله عن قصة عمر.

- وقال بدر الدين العيني: هذا الخبر منقطع. الثامن: هو الجواب القاطع: أن الإجماع انعقد على جواز إعطاء الرجل

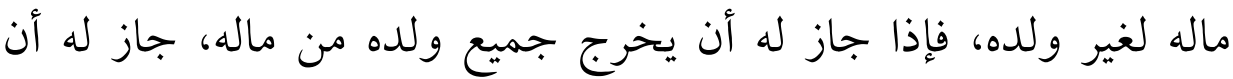
يخرج عن ذلك لبعضهم، ذكره ابن عبد البر. - قيل: فيه نظر؛ لأنه قياس مع وجود النص.

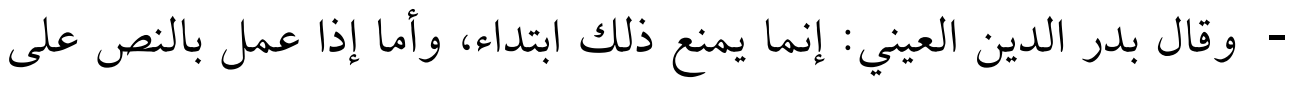
وجه من الوجوه، ثم إذا قيس ذلك الوجه إلى وجه آخر، لا يقال: إنه عمل بالقياس مع وجود النص. فافهم. التاسع: وقع عند مسلم عن ابن سيرين ما يدل على أن المحفوظ في حديث النعمان: (قاربوا بين أولادكم) لا (سووا). - وتعقب: بأن المخالفين لا يوجبون المقاربة كما لا يوجبون التسوية. •العاشر: في التشبيه الواقع في التسوية بينهم بالتسوية منهم في بر الوالدين، قرينة تدل على أن الأمر للندب، لكن إطلاق الجور على عدم التسوية، والمغهوم من قوله (لا أشهد إلا على حق) يدل للوجوب، وقد قال في آخر الرواية التي فيها التشبيه: (فلا إذًا)، لكن في التمهيد: يحتمل أنه أراد بقوله: (إلا على حق)، الحق الذي لا تقصير فيه عن أعلى مراتب الحق، 
وإن كان ما دونه حقًّا. وقال غيره: الجور الميل عن الاعتدال فالمكروه أيضا جور. حادي عشر: الإجماع انعقد على جواز عطية الرجل ماله لغير ولده، فإذا

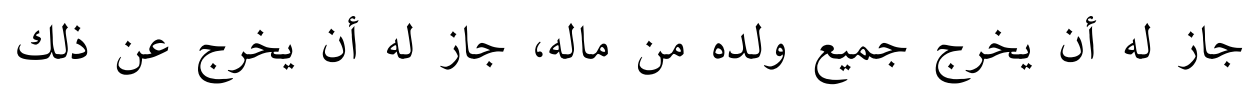
لبعضهم. ذكره ابن عبد البر.

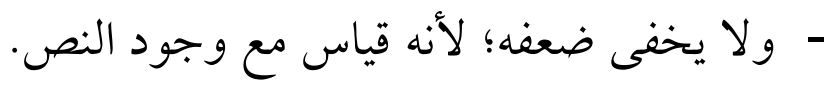

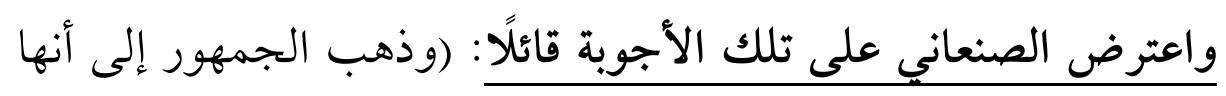

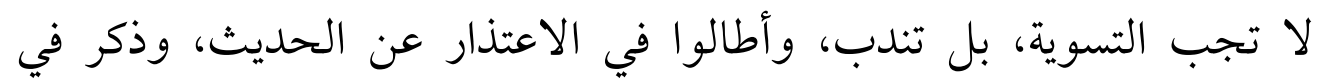

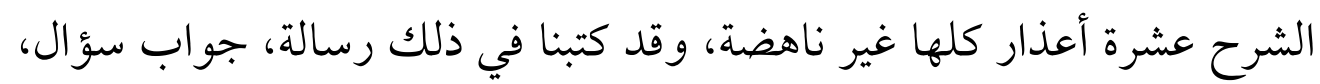
أوضحنا فيها قوة القول بوجوب التسوية، وأن الهبة مع عدمها باطلة) (1). ب- ولأنه تصرف في خالص ملكه، لا حقَّ لأحدٍ فيه، إلا أنه لا يكون عدلاً "()

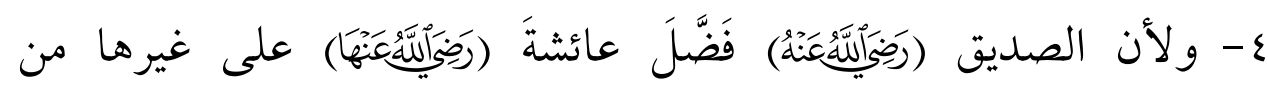

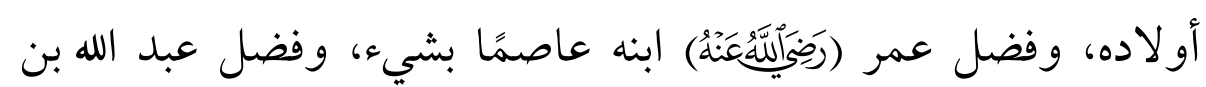

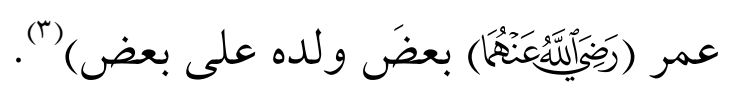

- - ولأنه يقع في نفس المفضول ما يمنعه من بره؛ فإن القرابة يَنفَُ

$$
\begin{aligned}
& \text { (1) سبل السلام، للصنعاني (r/• (1 ) . }
\end{aligned}
$$

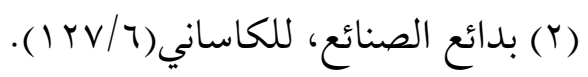

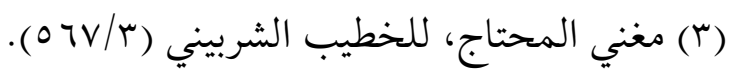


بعضُهم بعضًا ما لا يَنَفس العِدَى (1). ونحن نقول: لا يستحب للإِنسان

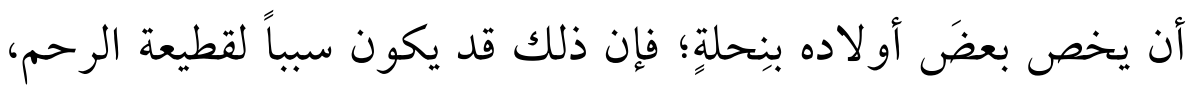
وقد يحمل المحروم على خلاف البر ب(r).

\section{واستدل أصحاب القول الثالث، القائلون بجواز التفضيل، بما يلي:}

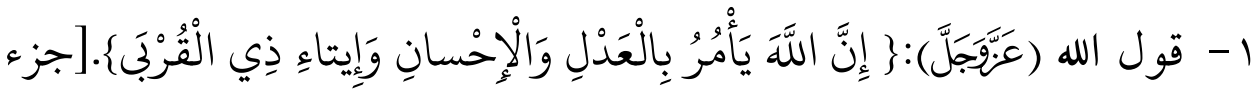

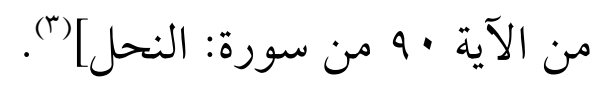

وجه الدلالة: أن قوله تعالى:\}وَإِيتاءِ ذِي الُْقْْبَيقيقد به: صلة الرحم،

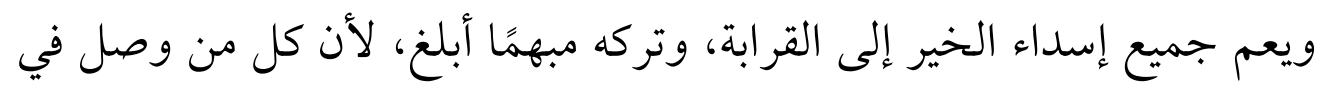
ذلك إلى غاية -وإن علت- يرى أنه مقصر، وهذا المعنى المأمور به في

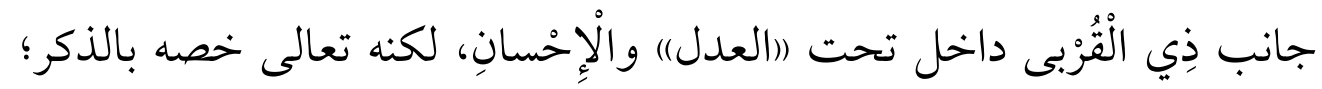

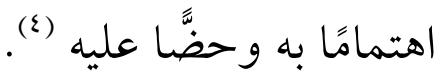

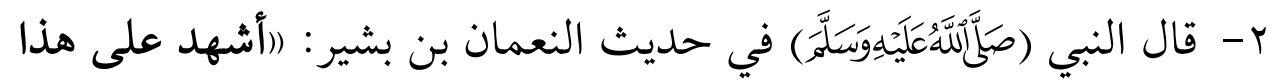
غيري).

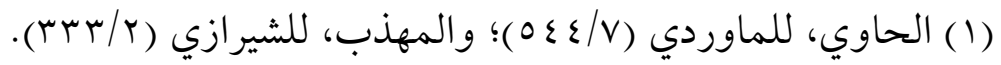

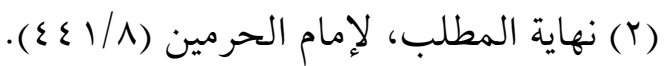

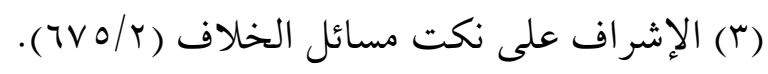

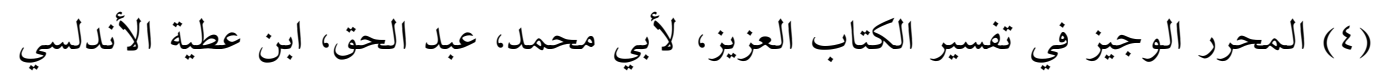

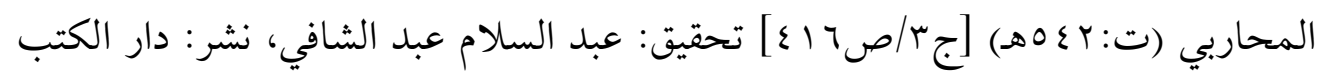

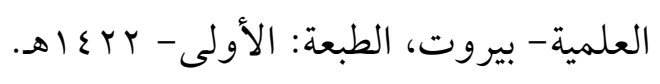




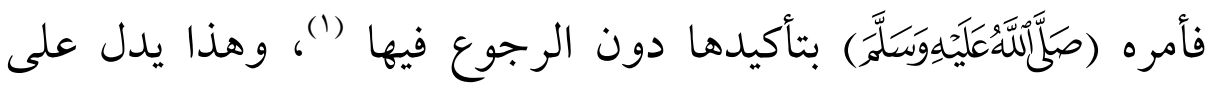

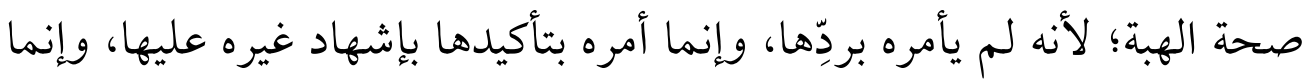

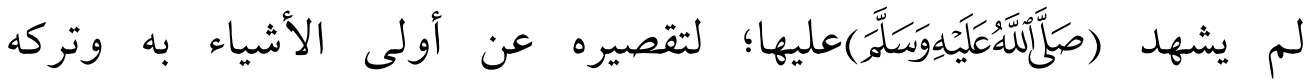

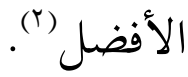

فهذا القول لا يدل على فساد العقد الذى عُقِدَ للنعمان؛ لأن النبي

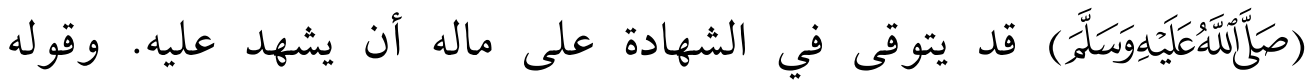

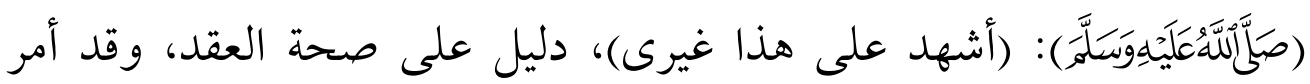

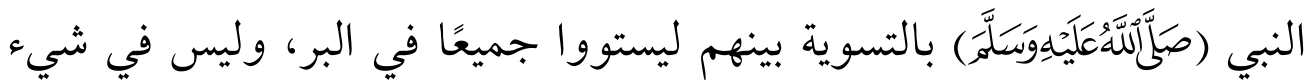

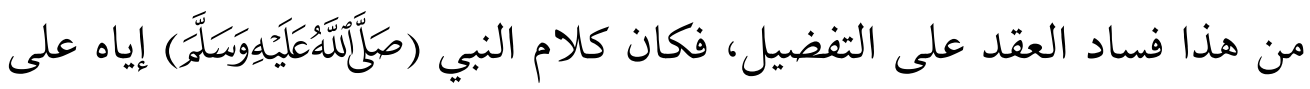

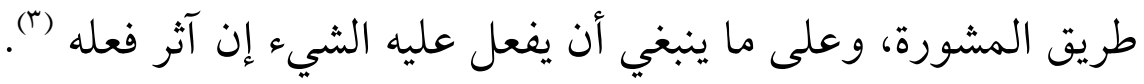

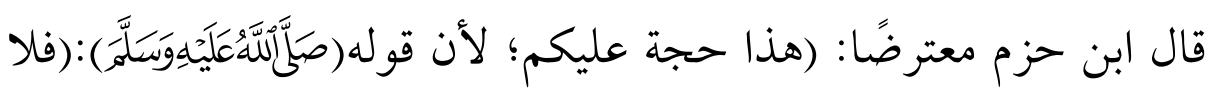
إذًا) نهيّ صحيحٌ كافِ لمن عقل.

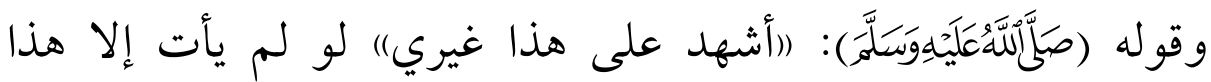
اللفظ لما كان لكم فيه متعلق) (8) .

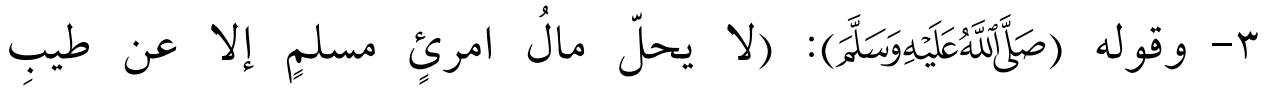

$$
\begin{aligned}
& \text { (1) تفسير القرطبي (T/乏) (Y)؛ والمغني لابن قدامة (T/T/Yr). }
\end{aligned}
$$

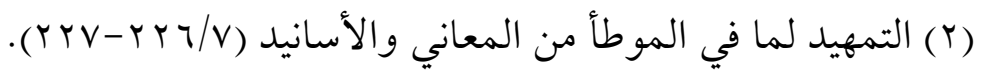

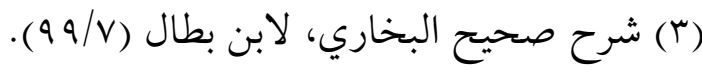

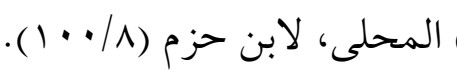




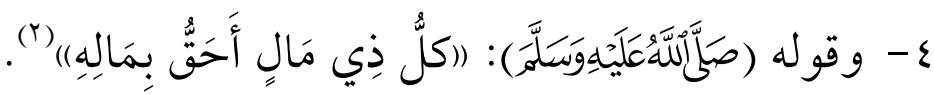

و اعترض ابن حزم قائلاً: (وأما الخبر ((كل ذي مال أحق بماله))

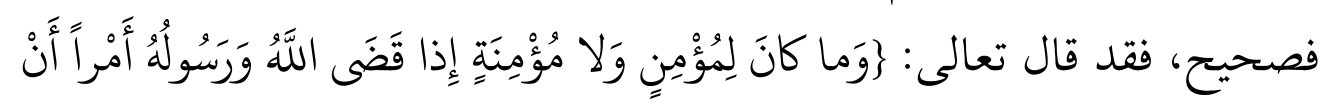

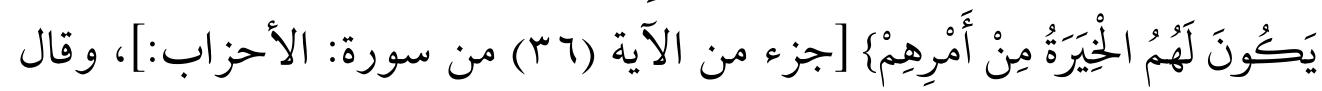

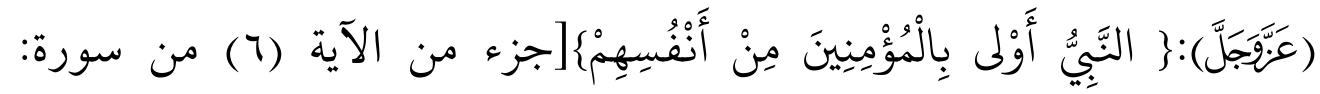
الأحزاب] فالذي حكم بايجاب الزكاة، وفسخ أجر البغي، وحلوان الكاهن، وبيع الخمر، وبيع أم الولد، وبيع الربا، هو الذي فسخ الصدقة والعطية المفضل فيها بعض الولد على بعض، ولو أنهم اعترضوا أنفسهم بهذا الاعتر اضى في إبطالهم النحل والصدقة التي لم تقبض لكان أصح وأثبت) (r).

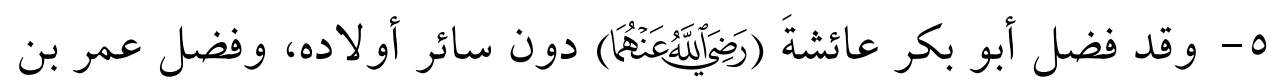

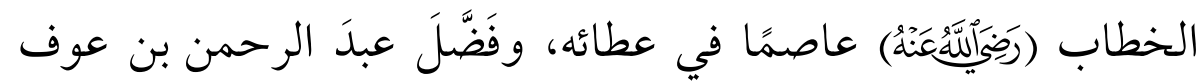

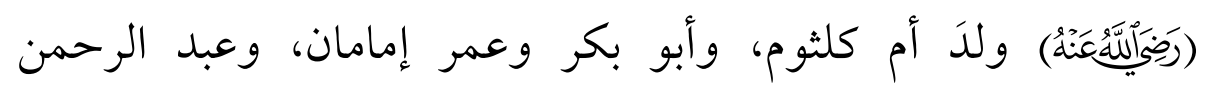
ومحله، ولم يكن في الصحابة من أنكر ذلك عليهم، فيكون إجماعًا (ع).

$$
\begin{aligned}
& \text { الإشراف على نكت مسائل الخلاف (r/ (TV0). }
\end{aligned}
$$

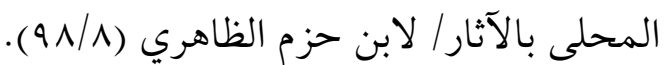

$$
\text { المحلى، لابن حزم(1/ • (1) ). }
$$

فيض القدير شرح الجامع الصغير، لزين الدين محمد المدعو بعبد الرؤوف بن تاج العارفين بن علي بن زين العابدين الحدادي ثم المناوي القاهري (المتوفى: اسب اهـ) [ج/rv/l نشر: المكتبة التجارية الكبرى - مصر، الطبعة: الأولى، جهمباهـ؛ ومرقاة 
وأجيب عن تصرف الصديق بعدة أجوبة (1)، ويمكن الجواب بها أيضًا

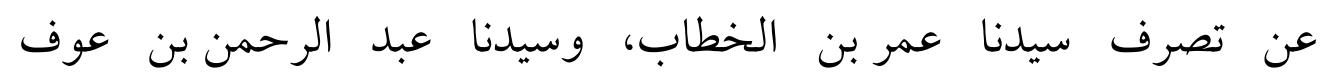

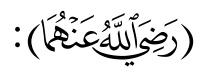

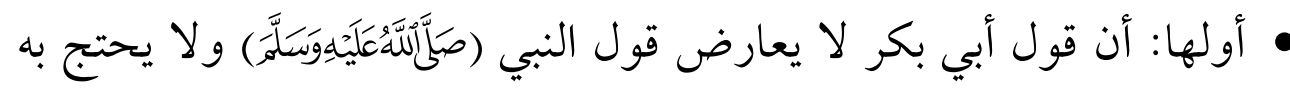
معه.

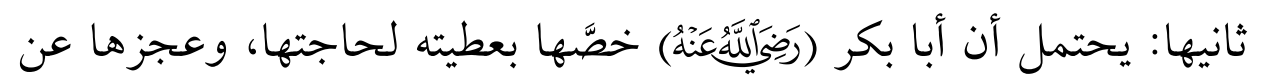

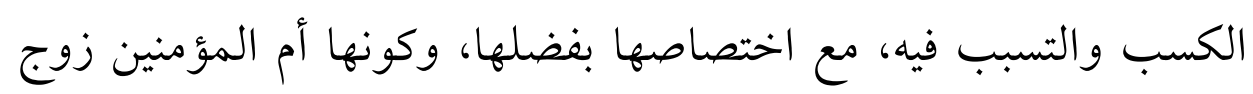

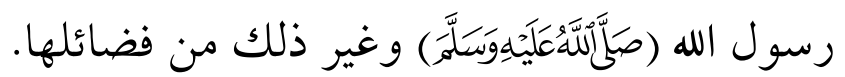

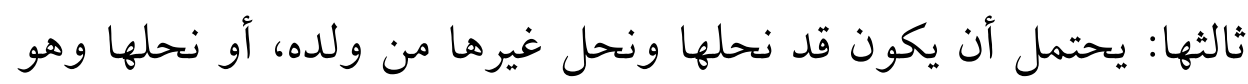

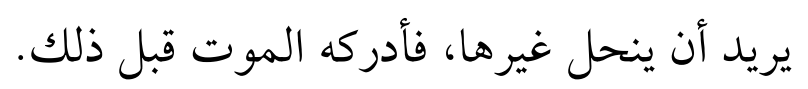

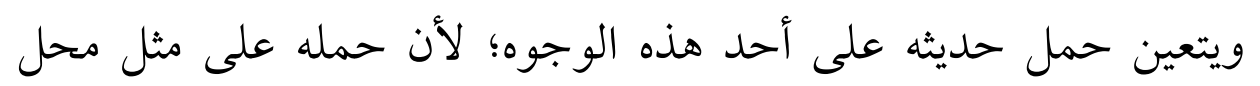

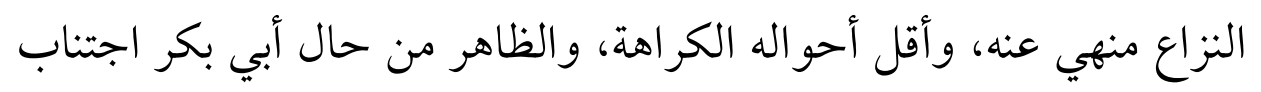
المكروهات. 7- ولأنه رشيدُ صحيحٌ وَهَبَ ماله من لو وهبه لغيره معه لجاز، فإذا أفرده

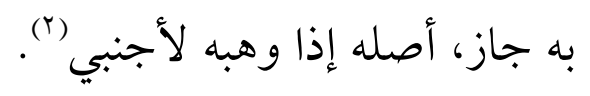

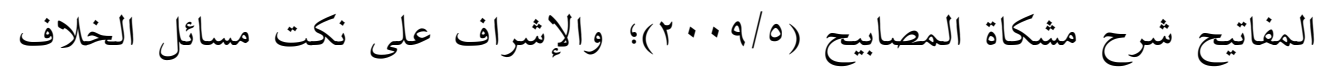

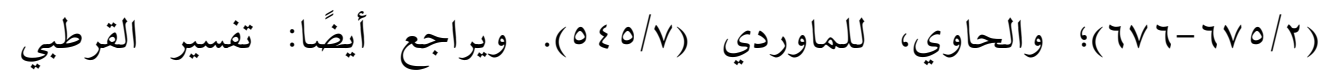

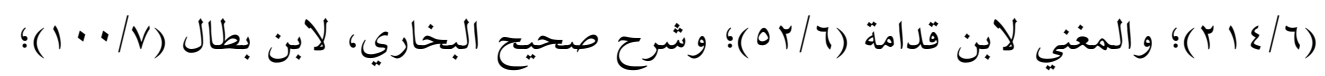

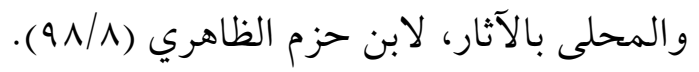

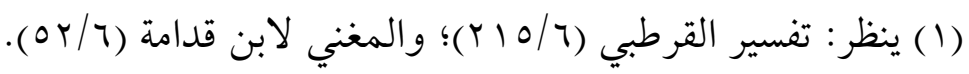

$$
\begin{aligned}
& \text { (r) الإشراف على نكت مسائل الخلاف (T/TT/T) }
\end{aligned}
$$


V- ولأن في حال الصحة لا اعتراض لأحد عليه في ماله، وإنما الاعتر اض حال المرض (1).

^- ولأن الإجماع منعقد على أن للرجل أن يهب في صحته بعض ماله لأجنبي، ولا يعطي أولاده شيئًا، فإذا اختار أن يعطي أجنبيَّا ويحرم

ولده كلهم، كان له أن يعطي بعضهم ويحرم بعضهم (r).

9- ولأنه لما جازت هبة بعض الأولاد للأب، جازت هبة الأب لبعض

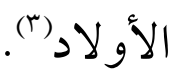

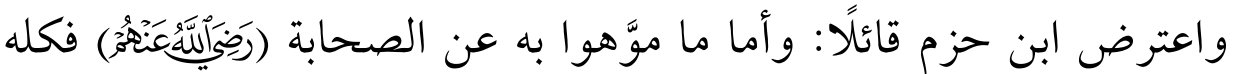

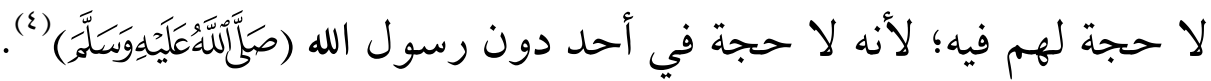

• 1 - ولأنها عطية تلزم بموت الأب، فكانت جائزة، كما لو سوى بينهم (0).

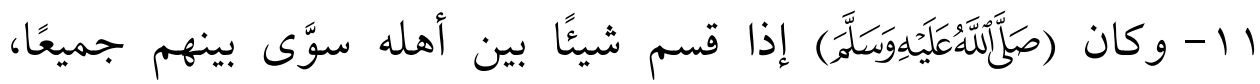
وأعطى المملوك كما يعطى الحر، ليس ذلك على أنه واجب، لكنه أحسن من غيره، وقد روى معمر، عن الزهري، عن أنس، قال: كان مع

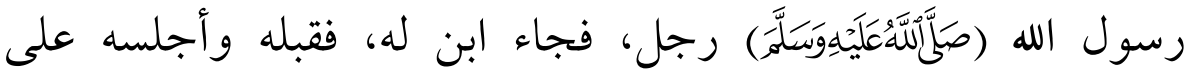

$$
\text { (1) (1) المرجع السابق نفسه. }
$$

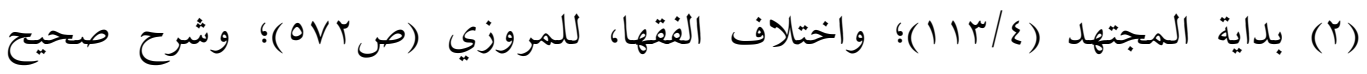

$$
\begin{aligned}
& \text { البخاري، لابن بطال (v/. - (). }
\end{aligned}
$$

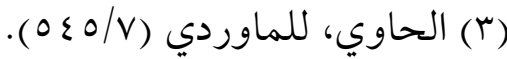

$$
\begin{aligned}
& \text { (المحلى، لابن حزم (1/ • • (1). } \\
& \text { (0) المغني، لابن قدامة (7/ or). }
\end{aligned}
$$




\section{فخذه، ثم جاءت ابنة له، فأجلسها إلى جنبه (1).}

r ا - ولأن العلماء مجمعون على جواز عطية الرجل ماله لغير ولده، فإذا جاز أن يُخرِجَ جميع ولده عن ماله، جاز له أن يُخرج عن ذلك

\section{(r) بعضهم}

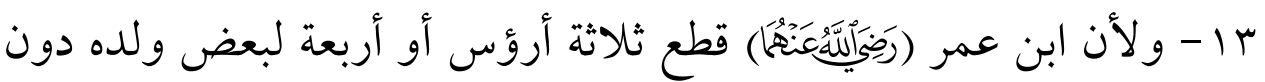

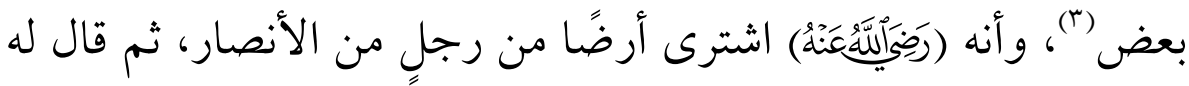
ابن عمر: هذه الأرض لابني واقد، فإنه مسكين، نحله إياها دون ولده

واعترض ابن حزم قائلاً: وأما الرواية عن ابن عمر فليس فيها أنه لم ينحل الآخرين قبل ولا بعد بمثل ذلك، بل فيها أنه قال: واقد ابني

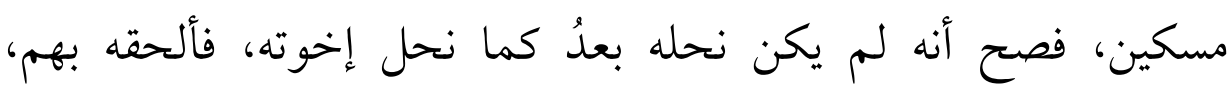
وأخرجه عن المسكنة، على أنها من طريق ابن لهيعة، وهو ساقط (0).

ع ا - ولأن هذا عمل الناس (T). واعترض ابن حزم قائلاً: عمل الناس الغالب عليه الباطل. وقال أنس: ما

$$
\begin{aligned}
& \text { (1)شرح صحيح البخاري، لابن بطال (v/ . (1). } \\
& \text { (r) التمهيد، لابن عبد البر (Y/ • (Y). }
\end{aligned}
$$

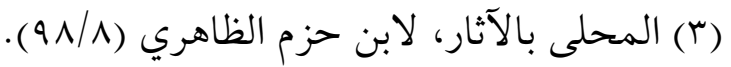

$$
\begin{aligned}
& \text { (ع) المرجع السابق نفسه. } \\
& \text { (0) المرجع السابق (1/ • • (1). } \\
& \text { ( ) المرجع السابق(^/ع • • (1). }
\end{aligned}
$$


أعرف مما أدركت الناس عليه إلا الصلاة (1).

1 - ولأنه لما جازت مفاضلة الإخوة، جازت مفاضلة الأولاد. واعرضى ابن حازم قائلاً: (هذا حكم إبليس، وهلا قلتم: لََّّا جاز القَوَدُ بين المرء وأخيه، جاز بين المرء وولده؟ فكان أصح) (؟).

\section{القول الراجح، وسبب الثترجيح:}

يترجح للى الباحث: القول بالمنع من تفضيل بعض الأبناء على بعضى - إذا لم تو جد علة معتبرة تقتضي التفضيل - وأن الأمر بالتسوية محمول على الوجوب، والنهي عن التفضيل محمولٌ على التحريم إذا نوى به حرمان غيره من الميراث أو الإضرار ببقية أبنائه، فحينها يحرم التفضيل ولا يجوز؛ لأنه إضرار بالغير، والشريعة لا تُقرِّر الضررَ ولا ترضاه، قال بدر الدين العيني: (وأما الاحتيال لإبطال حت المسلم فإثم وعدوان. وقال النسفي في الكافي عن محمد بن الحسن قال: ليس من أخلاق المؤمنين الفرار من أحكام الله بالحيل الموصلة إلى إبطال الحت)(r)؛ ولأنه سيؤدي في المآل -غالبًا- إلى وجود الأحقاد والضغائن بين الأبناء، وقد قال الشاطبي:(النظر في مآلات الأفعال

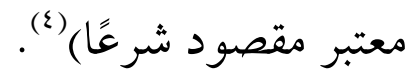

$$
\begin{aligned}
& \text { (1) المرجع السابق نفسه. }
\end{aligned}
$$

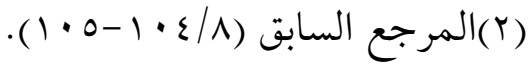$$
\text { (r) عمدة القاري شرح صحيح البخاري (ع ( / • (1). }
$$

(ع) الموافقات، لإبراهيم بن موسى بن محمد اللخمي الغرناطي الشهير بالشاطبي (المتوفى: • و هـ) [جه/ص[VV] تحقيق: أبو عبيدة مشهور بن حسن آل سلمان، نشر: دار ابن 
وأما إذا كان التفضيل لا بقصد الإضرار بالغير، فإنه يكون مكروهًا، ويُحمل الأمر بالتسوية بين الأبناء على الندب كما قال الجمال الجمهور.

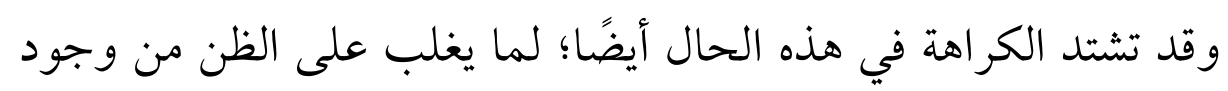

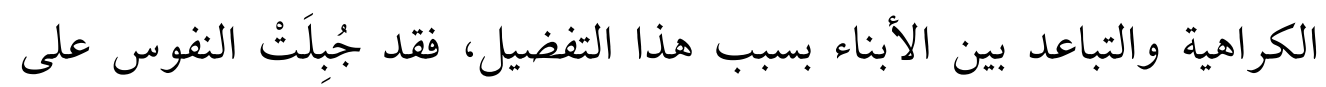

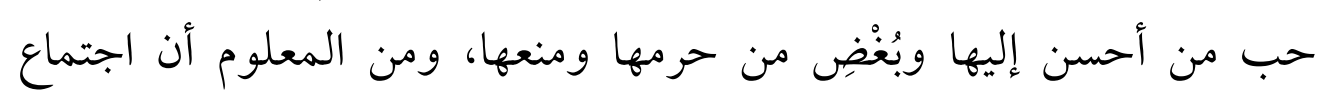

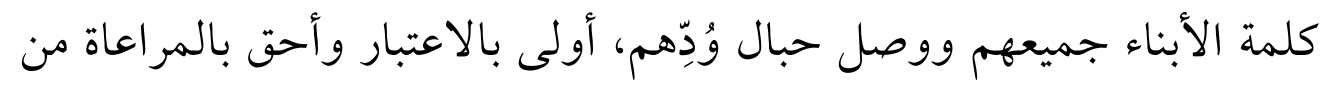

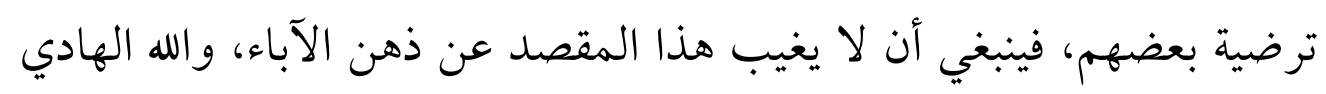
والمعين.

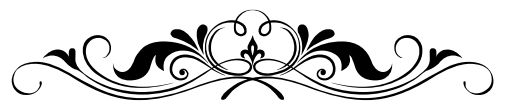

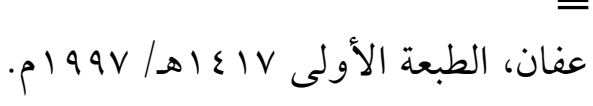




\section{المبحث الخامس}

\section{طريقة العدل بـين الأولاد في العطية}

بعد أن تعرض الباحث لأقوال الفقهاء في حكم التسوية بين الأبناء في العطية، يرد استفسار عن كيفية العدل بين الأولاد، هل يتحقق العدل بالتسوية بين ذكرهم وأثناهم، أم يُعطَ الذكر مثل حظ الأنثين كقسمة الميراث؟ ومن يطالْ آقو الَ الفقهاء يجذْ أن لهم في هذه المسألة قولين:

القول الأول: العدل في ذلك: أن يسوّيَ بينهم في العطية، ولا يفضل الذكر على الأنثى، فعليه أن يعطيَ الأنثى مثلما يعطي الذكر . وممن قال بذلك سفيان الثوري، وابن المبارك (')، وبه قال أبو يوسف من الحنفية (r)، وهو المختار عندهم (َ). وإلى هذا القول ذهب ابن القصار ...

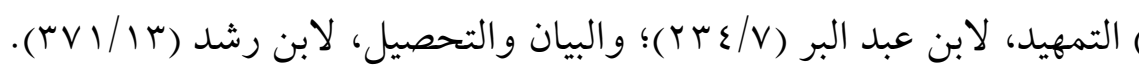

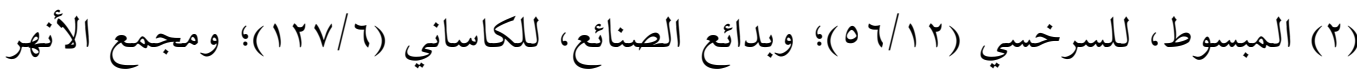

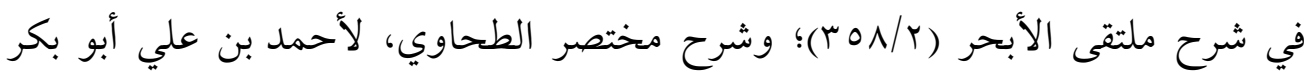

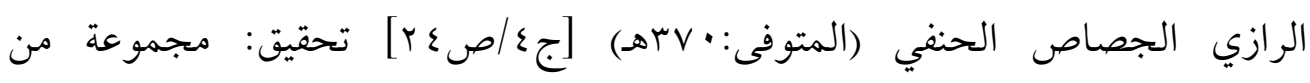

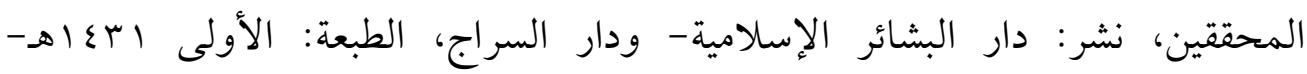

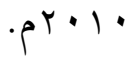

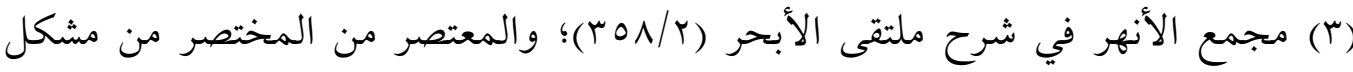

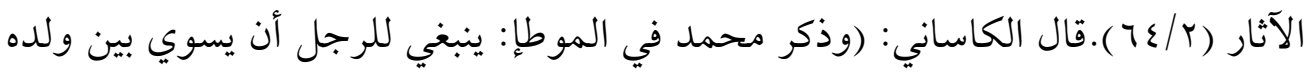

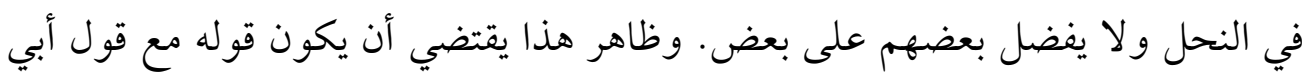

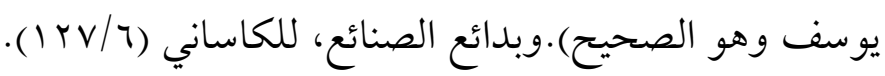

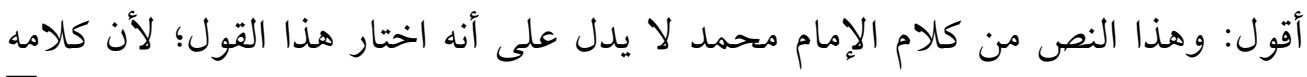
$=$ 
من المالكية(')، واختاره ابن المنذر(r)، وبه قال الشافعية في أحد الوجهين،

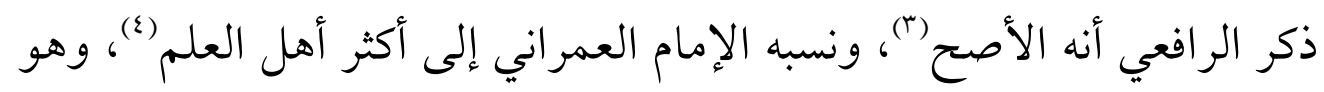

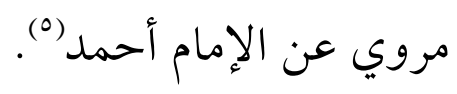

القول الثاني: يجريهم على طريقتهم في الميراث منه لو تُوفِّيَ، فيعطي للذكر مثل حظ الأنثين. وهو مذهب جماعة من السلف، منهم: عطاء بن أبي

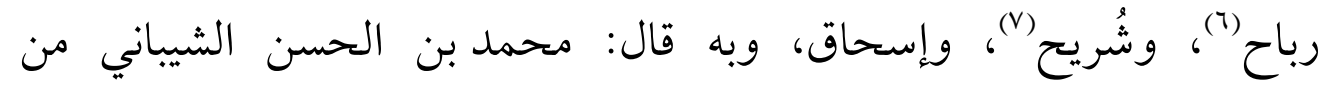
الحنفية(^)، وذكر السرخسي: أنه المذهب، وب.................................... يحتمل التسوية بين الأولاد، يعني: عدم تفضيل أحدهم عن بقية إخوته.

$$
\text { (1) (1) البيان والتحصيل، لابن رشد (rV/ / (rV). }
$$

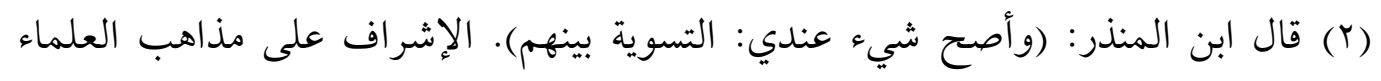
. ( $\vee q / V)$

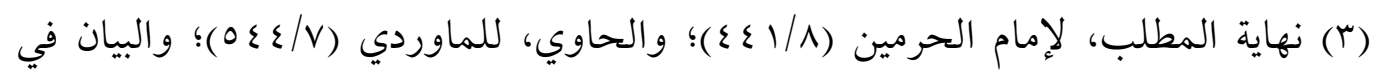

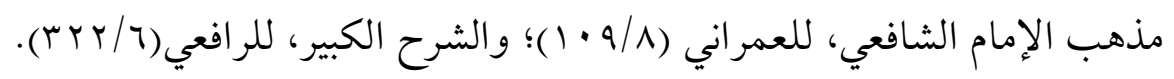

$$
\text { (ع) البيان في مذهب الإمام الشافعي، للعمراني (1/ ( • (1). }
$$

(0) قال المرداوي: (اختاره ابن عقيل في الفنون، والحارثي).الإنصاف في معرفة الراجح من

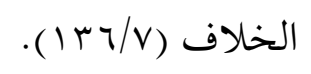

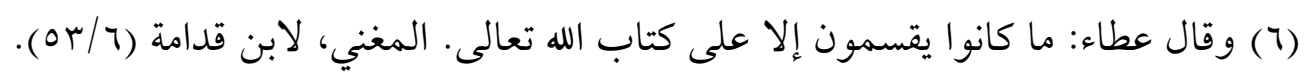

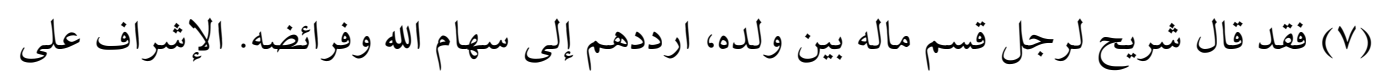

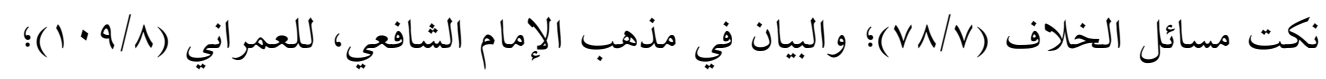

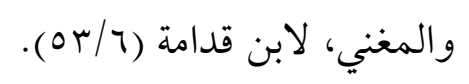

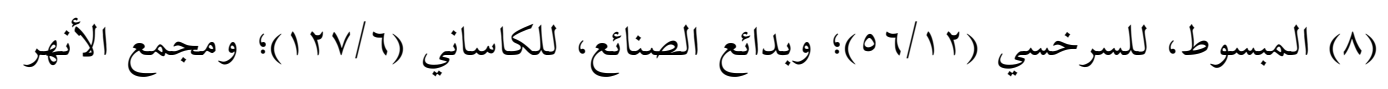

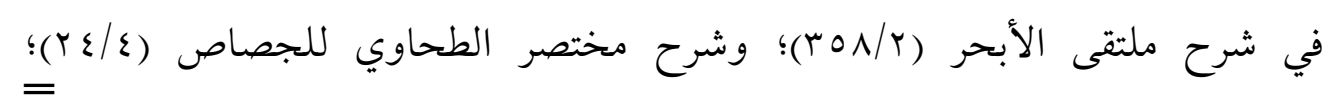


وعليه الاعتماد(1)، قال ابن عبد البر: ولا أحفظ لمالك في هذه المسألة

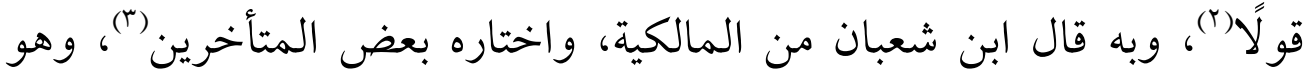

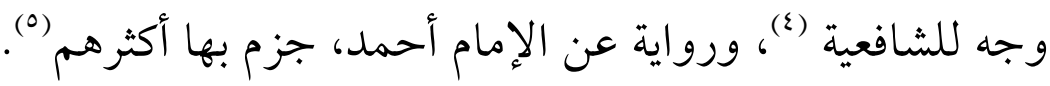

\section{الأدلة:}

استدل أصحابُ القول الأول القائلون بأن العدلَ أن يسويَ بين الذكر والأنثى في العطية بما يلي:

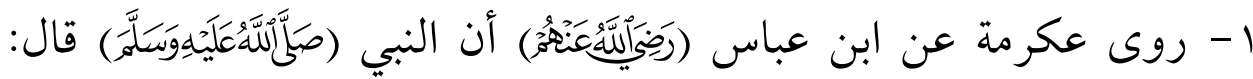

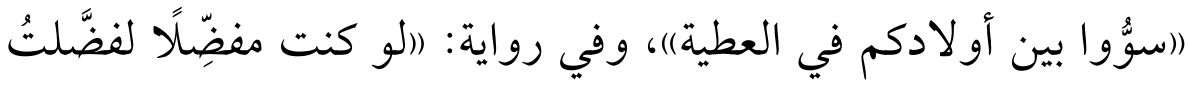

البناتِ)، أو: (لآثرت النساء على الرجال)" (ج).

$$
\text { و المعتصر من المختصر من مشكل الآثار (r/ (T). }
$$

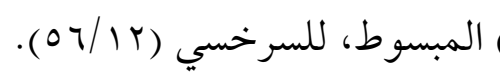

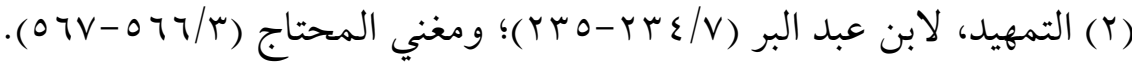

$$
\begin{aligned}
& \text { (r) البيان والتحصيل، لابن رشد (rV/Tr/T) }
\end{aligned}
$$

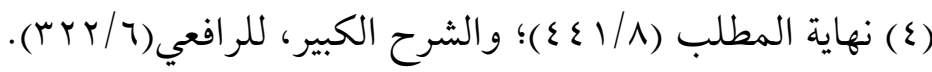

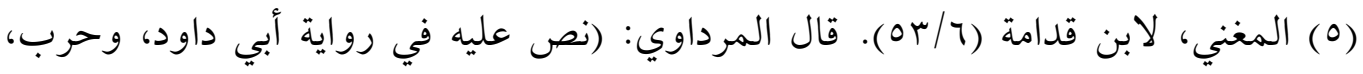

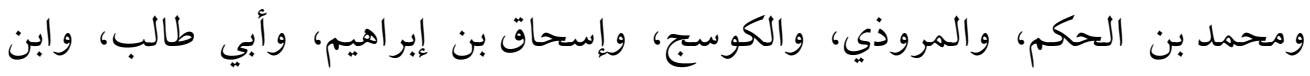

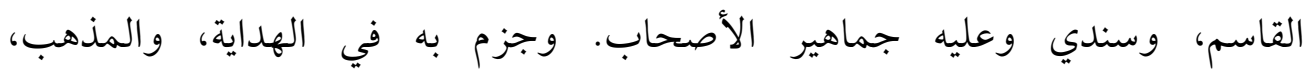

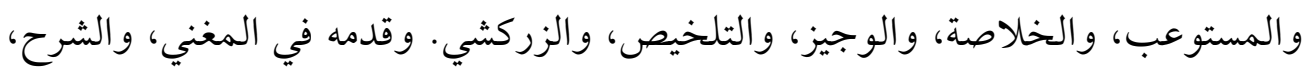

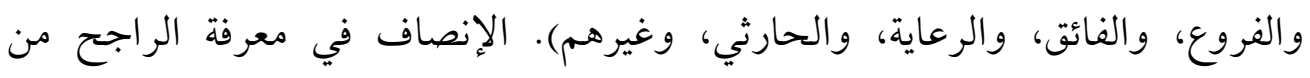

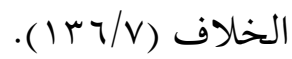

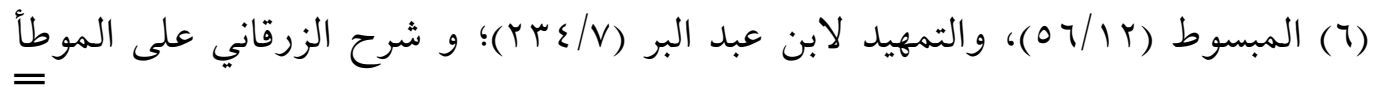




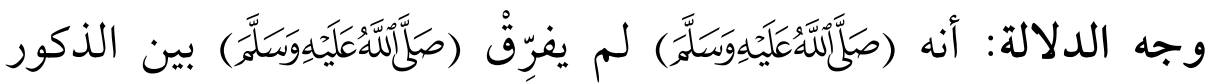

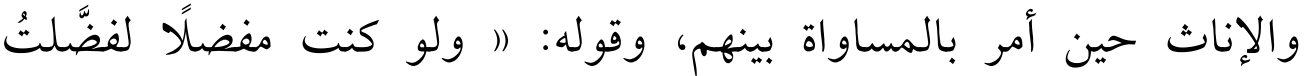

الإناث): يدل على التسوية أيضًا (1).

\section{واعترض: بأن هذا الخبرَ مرسلٌ (ب).}

r- حديث النعمان بن بشير الذي مرَّ الكلام فيه سابقًا، وفيه: أنه

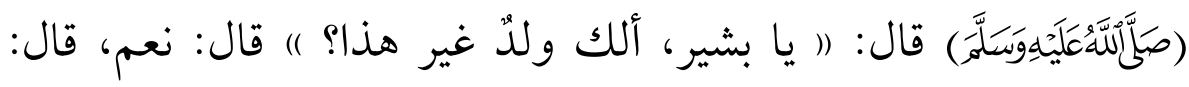

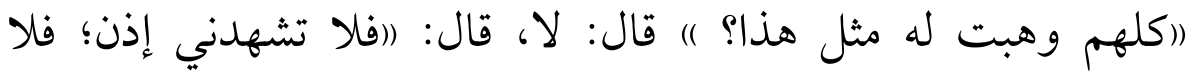

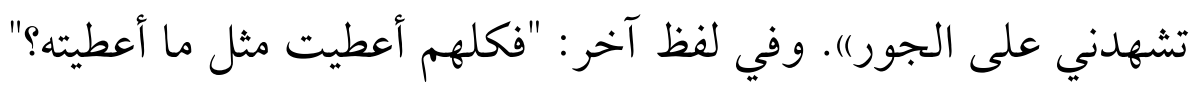

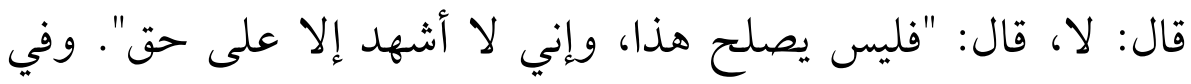

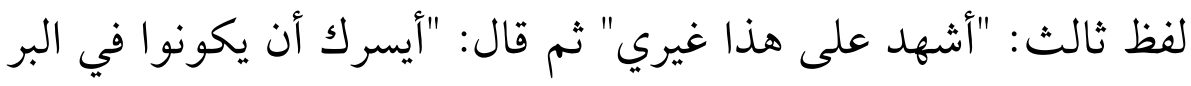

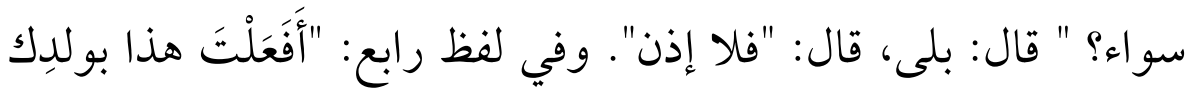

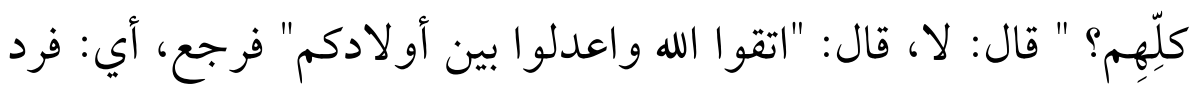

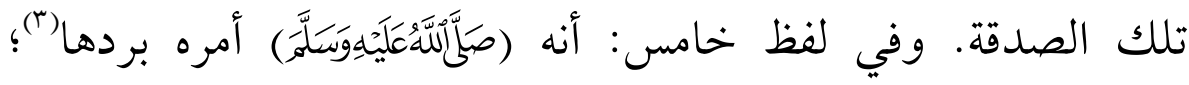

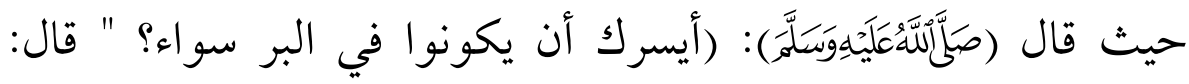

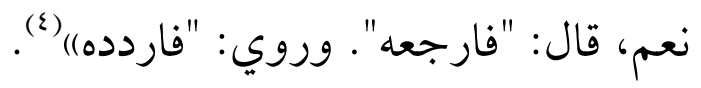

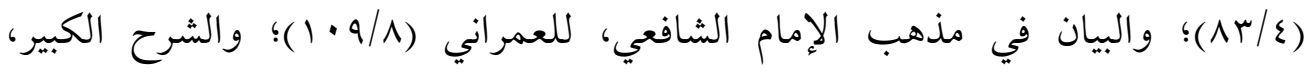

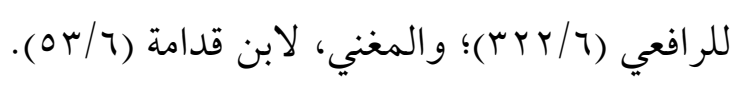

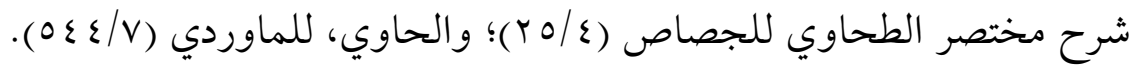

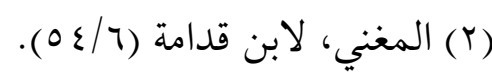

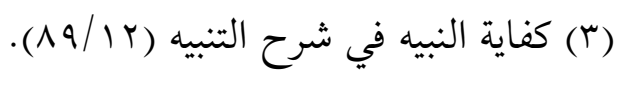

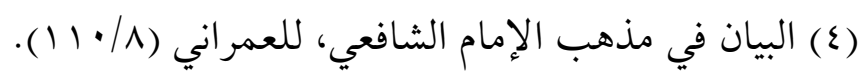




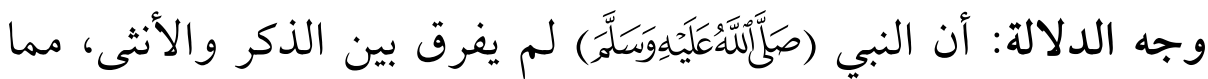

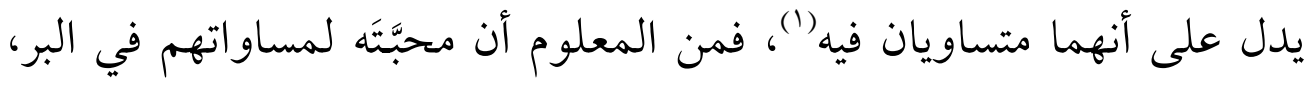

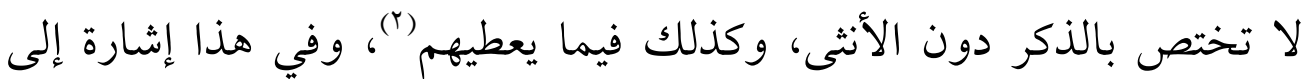
العدل بين الأولاد في النحلة، وهو: التسوية بينهم (ب).

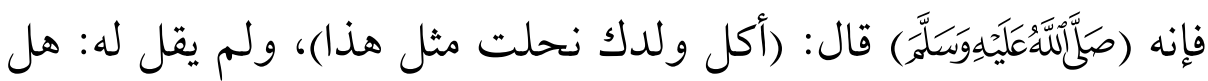

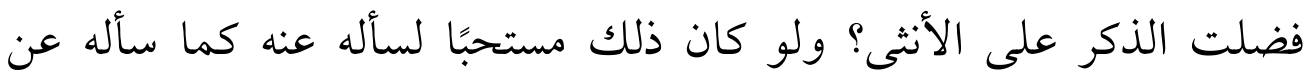

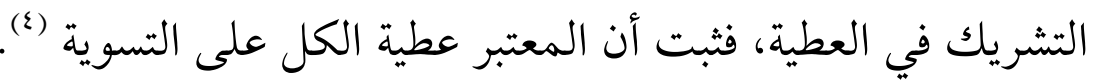

\section{ونوقش الاستدلال بهذا الحديث بما يلي:}

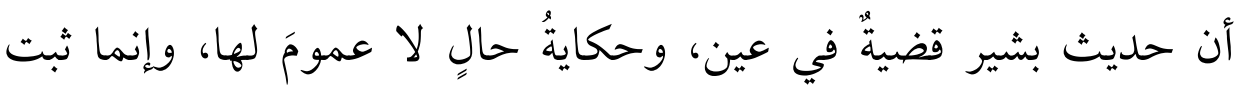

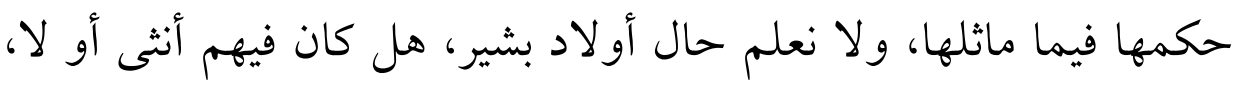

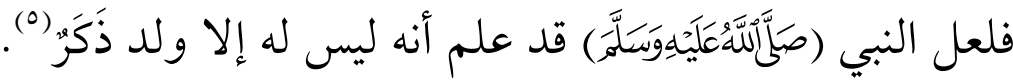

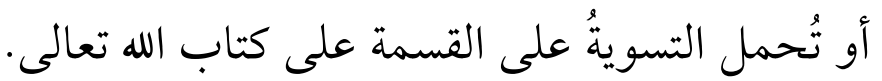

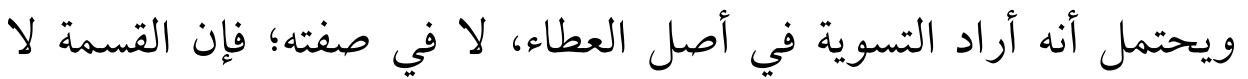

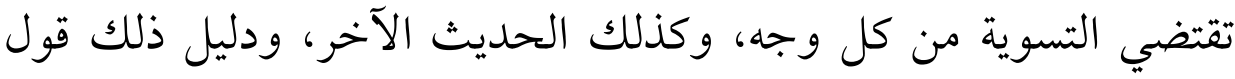

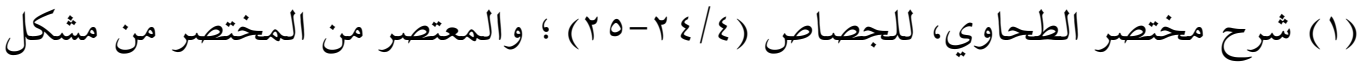

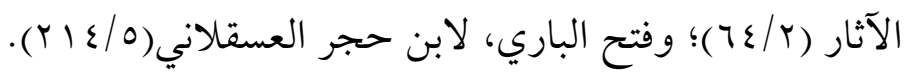
(r) شرح مختصر الطحاوي، للجصاص (ro/ (r).

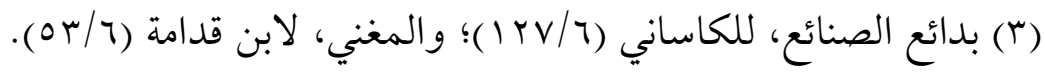

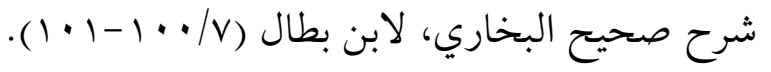

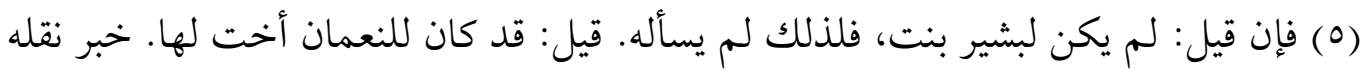
أصحاب الحديث. شرح صحيح البخاري، لابن بطال (v/ . (1-1 • (1). 
عطاء: ما كانوا يقسمون إلا على كتاب الله تعالى. وهذا خبر عن (1) جميعهم

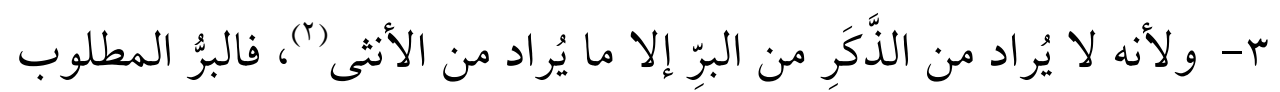

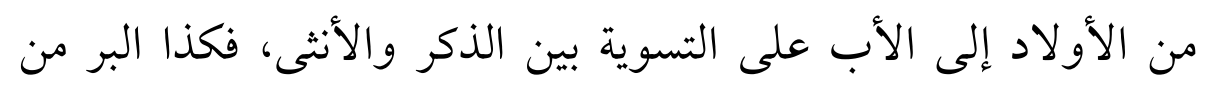

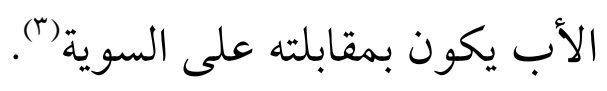

ع- ولأنه لما استُحِبَّ أن يساوي بينهم في أصل العطية، كذلك في

$$
\text { مقدارها }
$$

0- ولأنها عطية في الحياة، فاستوى فيها الذكر والأنثى، كالنفقة

$$
\text { و الكسوةة (0). }
$$

7- ولأن في التسوية تأليف القلوب، والتفضيل يورث الوحشة بينهم،

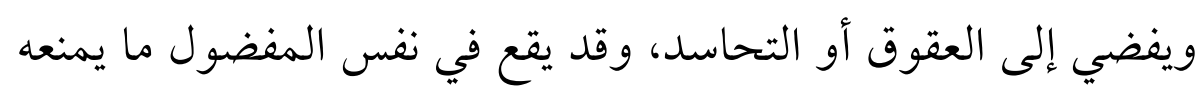

$$
\text { من برِّه (T)، فكانت التسوية أولى (v). }
$$

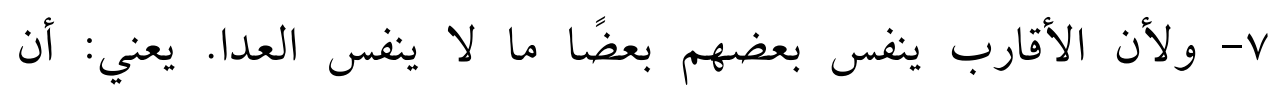

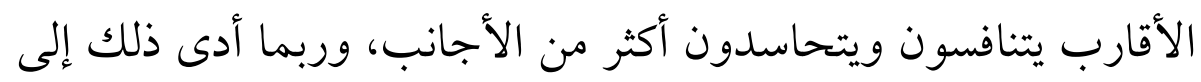

$$
\begin{aligned}
& \text { (1) المغني، لابن قدامة (T/ع ه). }
\end{aligned}
$$

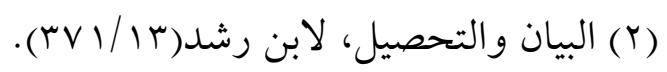

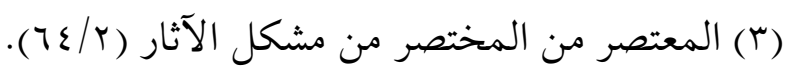

$$
\begin{aligned}
& \text { (ع) الإشراف على نكت مسائل الخلاف (T/T (TVT). }
\end{aligned}
$$

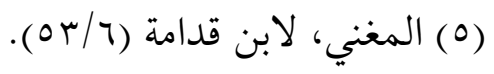

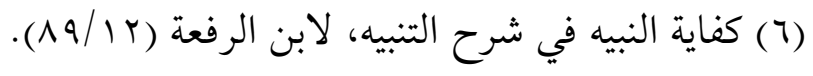

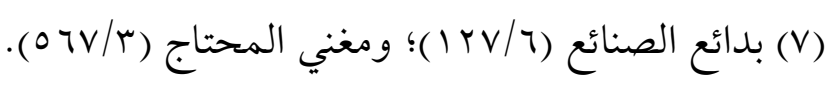


قطع الرحم. فالعِدا: الأجانب والأباعد، والعُدا: العداوة (1). واستدل أصحاب القول الثاني، القائلون بأن التسوية في عطية الأبناء تقتضي أن يعطَى الذكرُ ضعف الأنثى كقسمة الميراث، بما يلي:

ا - أنه لو مات استحقو اله كذلك، فكذلك في الحياة (r).

ץ- ولأن الله تعالى قسم بينهم، فجعل للذكر مثل حظ الأنثين، وأولى ما يُقتََدَى به قسمة الله (r) r- ولأن الشرع أعلمُ بمصالحنا، فلو لم يكن الأصلح التفضيل بين الذكر

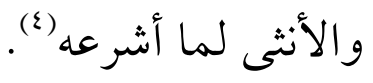

ع - ولأن العطية في الحياة أحد حالي العطية، فيجعل للذكر منها مثل حظ الأنثين، كحالة الموت (أي: الميراث). يحققه: أن العطية استعجال لما يكون بعد الموت، فينبغي أن تكون على حسبه، كما أن معجل الزكاة قبل وجوبها يؤديها على صفة أدائها بعد وجوبها، وكذلك الكفارات

$$
\text { (1) البيان في مذهب الإمام الشافعي، للعمراني (1/· • (1). }
$$

(Y) شرح مختصر الطحاوي للجصاص (ع/\%)؛ والمعتصر من المختصر من مشكل الآثار

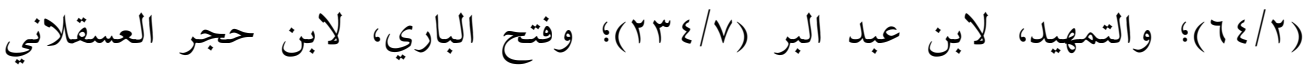

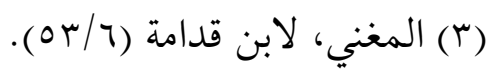

(ع) بدائع الفوائد، لأبي عبد الله، محمد بن أبي بكر بن أيوب ابن قيم الجوزية (ت: الوه Vهـ)

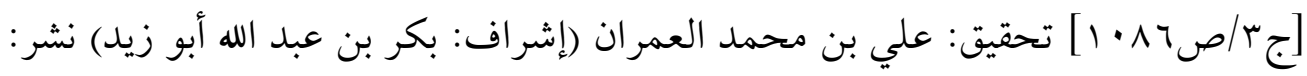

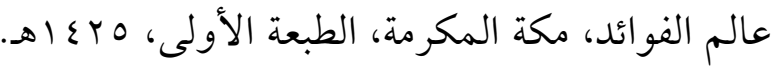




\section{(1) (1) - (1)}

ه - ولأن الذكر أحوج من الأنثى، من قِبَلِ أنهما إذا تزوجا جميعا فالصداق والنفقة ونفقة الأولاد على الذكر، والأنثى لها ذلك، فكان أولى بالتفضيل؛ لزيادة حاجته، وقد قسم الله تعالى الميراث، فضضل الذكر

مقرونا بهذا المعنى فتعلل به، ويتعدى ذلك إلى العطية في الحياة (r). ج- ولأن الله تعالى جعل الأنثى على النصف من الذكر في الثهادات، و الميراث، و الديات، وفي العقيقة، وذلك ثابت بالسنة (r).

\section{واعترض على قياس الهبة على الإرث بأمرين (ع):}

الأول: أن الوارثَ راضٍ بما فرض الله له، بخلاف هذا. قال الخطيب الشربيني: بل قيل: إن الأولَى أن تُفضَّلَ الأنثى. حكاه ابن جماعة

$$
\text { المقدسي في شرح المفتاح. }
$$

و الثاني: أن الذكر والأنثى إنما يختلفان في الميراث بالعصوبة، أما بالرحم المحددة، فهما فيها سواء، كالإخوة والأخوات من الأم، و الهبة للأو لاد

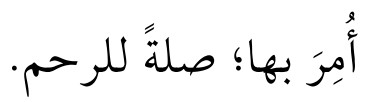

V- و لأن الله تعالى منع مما يؤدي إلى قطيعة الرحم، والتسوية بين الذكر

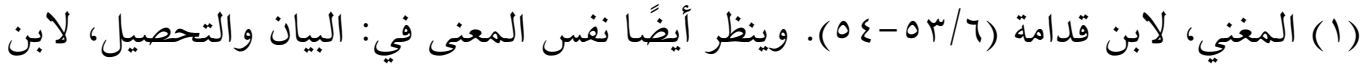

$$
\begin{aligned}
& \text { رشد (rVI/Ir). }
\end{aligned}
$$

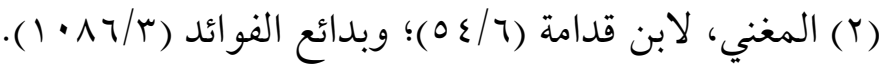

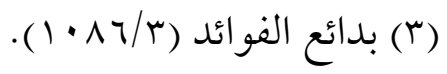

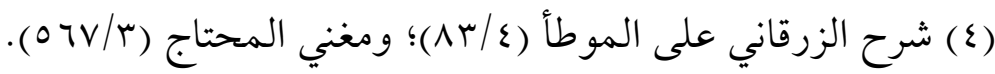


والأنثى مخالفة لما وضعه الشرع، فيفضي ذلك إلى العداوة (1). ^- ولأن الله تعالى جعل الرجالَ قوَّامين على النساء، فإذا علم الذكر أن الأب زاد الأنثى على العطية التي أعطاها الله وسواها بمن فضله الله

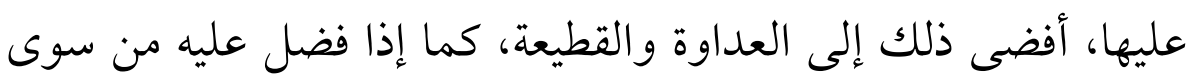
بينه وبينه (r)

واعترض على هذا القول: بأن بناء العطية حال الحياة والصحة والمال،

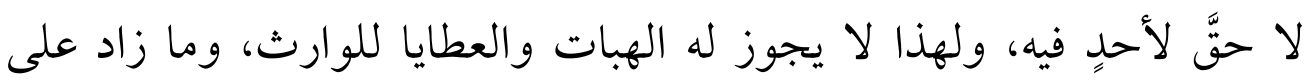

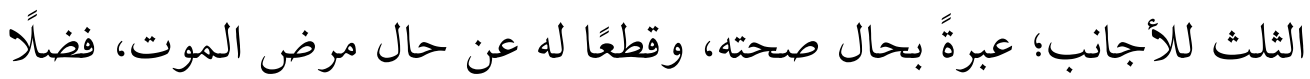
عن الموت، وكذا تعطَ الإخوة والأخوات مع وجود الابن والأب، وإن لم يكن لهم حق في الإرث، وتلك عطية من الله على سبيل التحكم لا اختيار لأحد فيها، وهذه عطية من مكلف غير محجور عليه، فكانت على حسب

$$
\text { اختياره من تفضيل وتسوية (r). }
$$

وأجيب: بأن هذه الحجة ضعيفة جدَّا؛ فإنها باطلة بما سلمه من امتناع التفضيل بين الأولاد المتساوين في الذكورة والأنوثة، وكيف يصح له قوله: "إنها عطية من مكلف غير محجور عليه، فجازت على حسب اختياره" وهو قد حجر عليه في التفضيل بين المتساوين؟ (ع).

$$
\begin{aligned}
& \text { (1) بدائع الفوائد (r/ ( • (1) ). } \\
& \text { (r) المرجع السابق نفسه. } \\
& \text { (r) المرجع السابق نفسه. } \\
& \text { (ع) المرجع السابق نفسه. }
\end{aligned}
$$




\section{القول المختار، وعلة اختياره:}

يترجح لدى الباحث القولَ الأوََ القائلَ بأن العدل بين الأولاد يقتضي

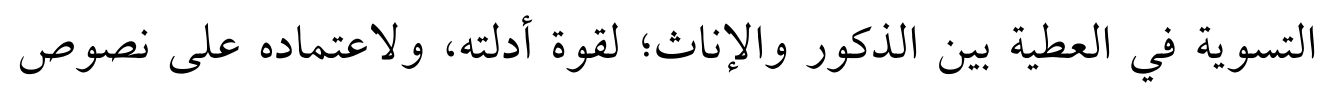

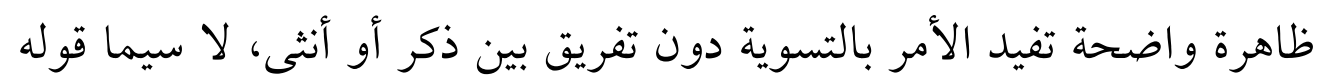

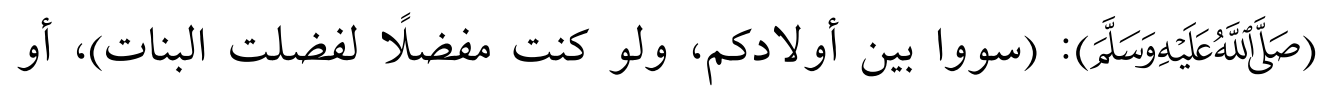

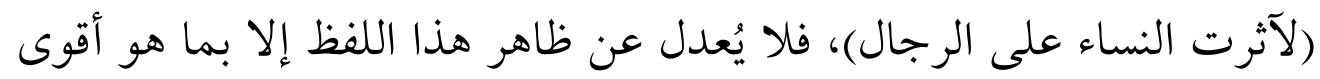

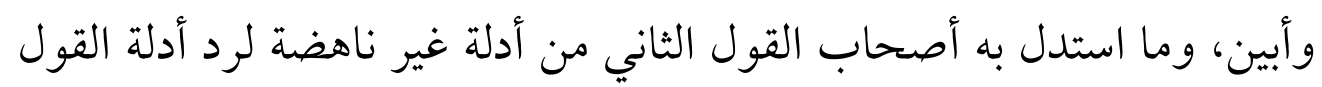

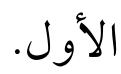

و القياس على قسمة الميراث قياس مع الفارق؛ فهذه هبة وذلك ميراث، ولكل باب منهما أحكامه الخاصة به.

والأمر محمول على الاستحباب، والعبرة فيه بتوافر الرضا، قال إمام

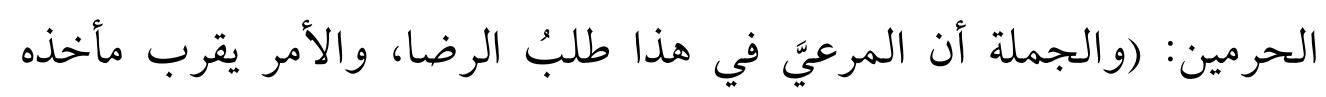

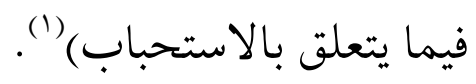

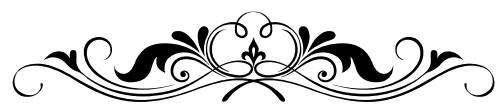

(1) نهاية المطلب (^/1) §). 


\section{المحث البسادس}

\section{الهبة مع التفضيل (بين النفاذ والبطلان)}

بقي الكلام فيما لو وقع التفضيل بالفعل لبعض الأبناء دون بعض -مع

رجحان القول بالمنع منه- هل تعد هبة صحيحة نافذة معمولًا بها؟ أو لا؟

\section{للفقهاء في المسألة أقوال أربعة:}

القول الأول: إن وقع التفضيل في عطية الأبناء، فإن هذه العطية -مع كراهتها- تقع صحيحة ماضية نافذة. قال ابن عبد البر : (فصح بهذا كله مذهب مالك، والثوري، والشافعي، ومن قال بقولهم في استحباب ترك التفضيل بين الأبناء في العطية، وإمضائه إذا وقع)('). وقال ابن حجر: (وذهب الجمهور إلى بـ أن التسوية مستحبة، فإن فضَّل بعضًا صحَّ، وكُره، واستحبت المبادرة إلى

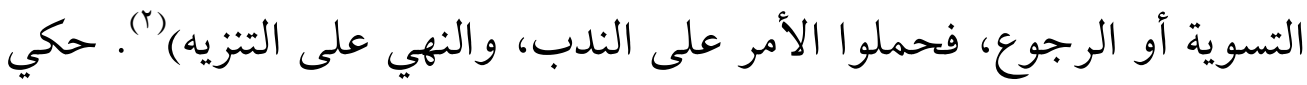

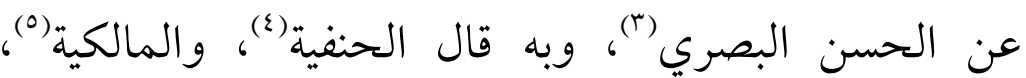

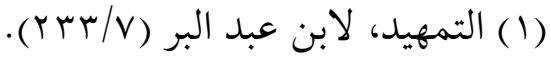

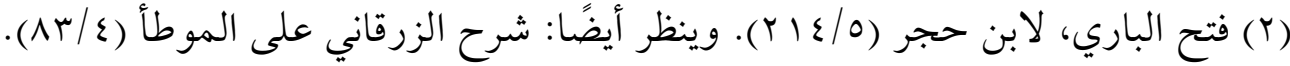
(r) قال ابن قدامة: (وكان الحسن يكرهه، ويجيزه في القضاء). المغني، لابن قدامة (7/ 10). قال الكاساني: (ولو نحل بعضا وحرم بعضا جاز من طريق الحكم؛؛ لأنه تصرف في

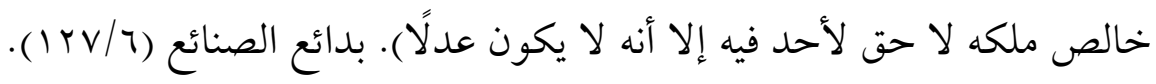

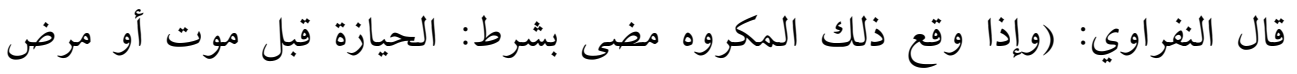

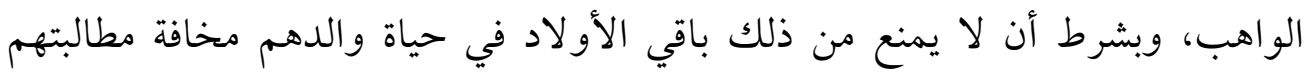

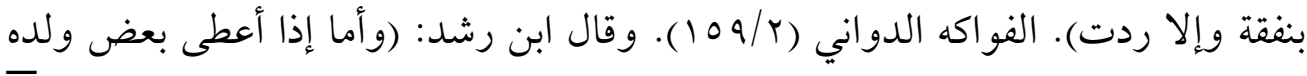


والشافعية (1).

القول الثاني: أنه لو فضَّل بعضَ بنيه، أَثِثَ، ووجبت عليه التسوية بأحد أمرين؛ إما بردِّ ما فضَّل به البعض، أو بإتمام نصيب الآخرين ليتساووا به. فإِن لم يفعل فالعطيةٌ باطلةٌ مفسوخةٌ، و وإن مات الناحل قبل إسل إستردادها، كانت

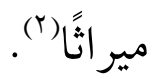

دون بعض ماله، وإن كان جله، وأبقى لنفسه بعضه فلا اختلاف في المذهب، ولا بين

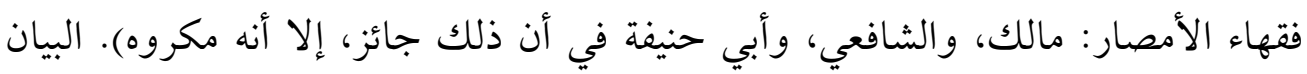

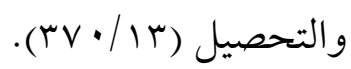

وقال أبو بكر الكشناوي: (وأما هبة جميع ماله لبعض ولده دون بعض بعض، أو تفضيل

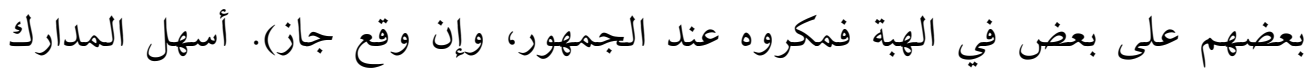

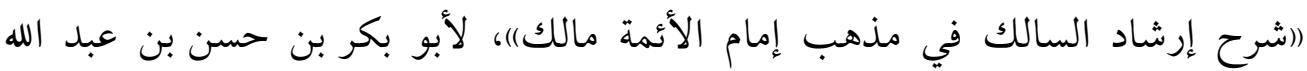

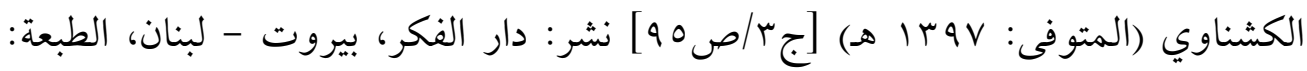

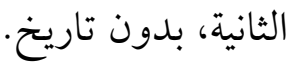
قال الماوردي: (فإن لم يسو بينهم وخص بالهبة بعضهم، كانت الهبة جائزة وإن أساء.

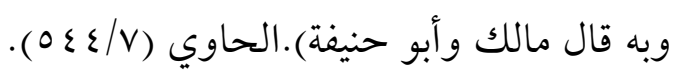

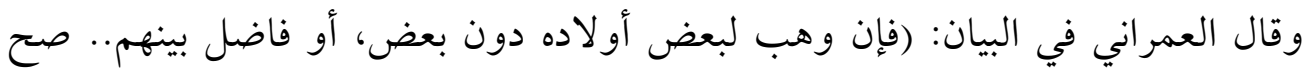

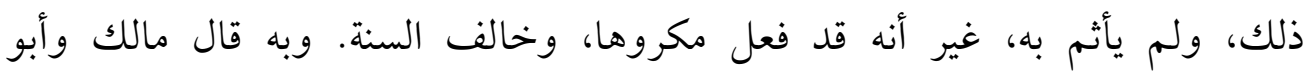

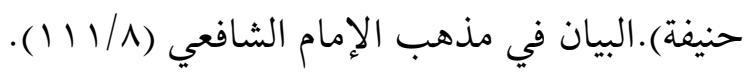

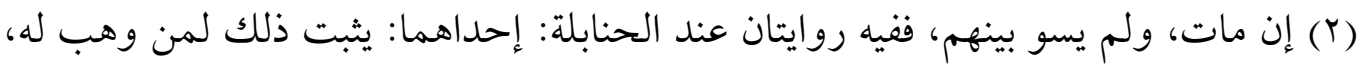

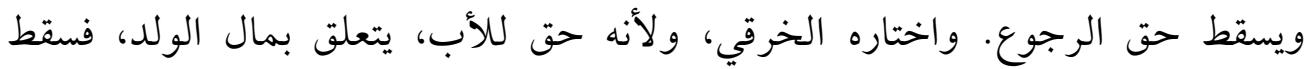
بموته، كالأخذ من ماله.

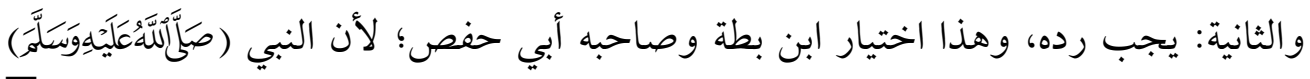
$=$ 
سمَّاه جورًا، والجور يجب رده بكل حال، والتسوية المأمور بها القسمة بينهم على قدر مواريثهم، لأنه تعجيل لما يصل إليهم بعد الموت، فأشبه الميراث. الكافي في فقه الإمام

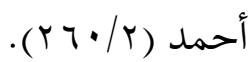

قال في المغني: (إذا فاضل بين ولده في العطايا، أو خص بعضهم بعطية، ثم مات قبل أن

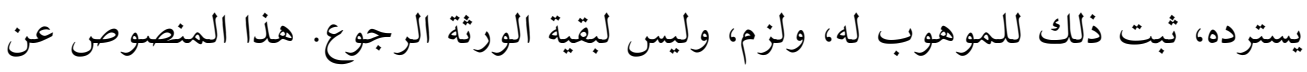
أحمد، في رواية محمد بن الحكم، والميموني، وهو اختيار الخلال، وصاحبه أبي بكر. لون.

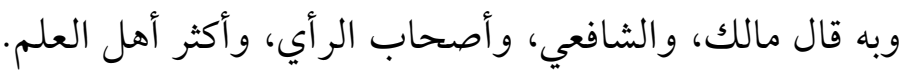

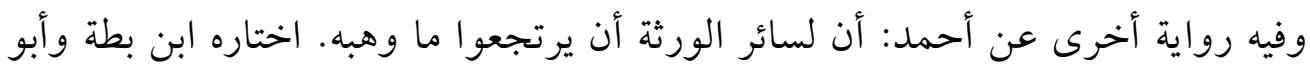

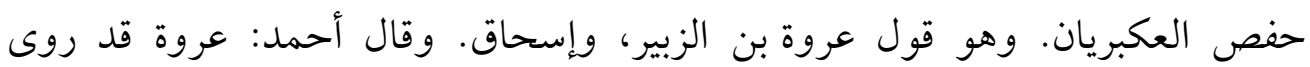

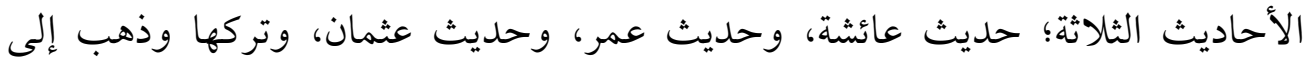

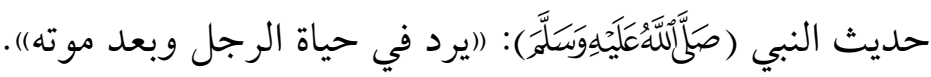

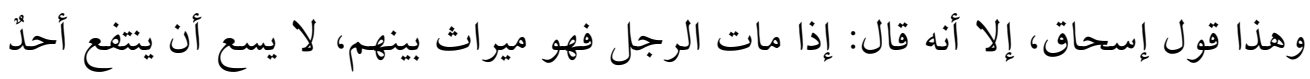

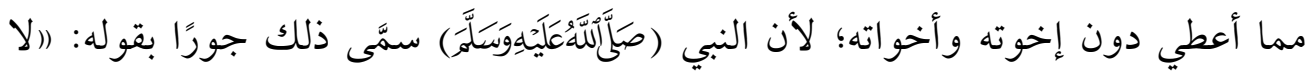

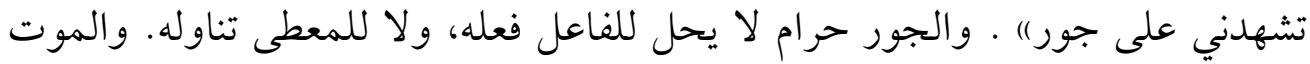

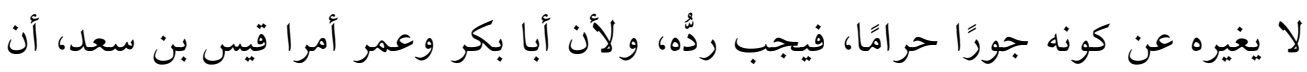

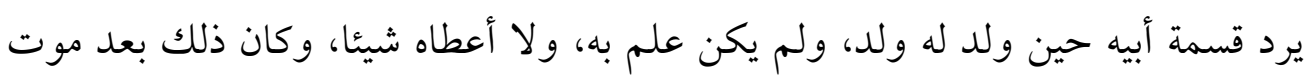

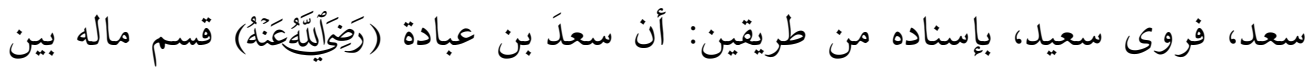

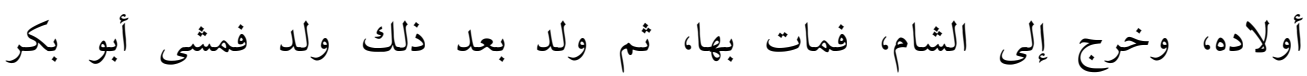

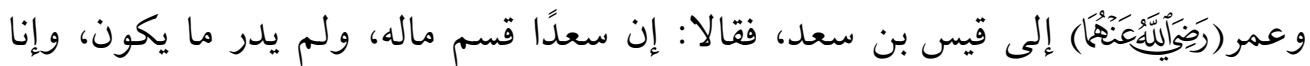

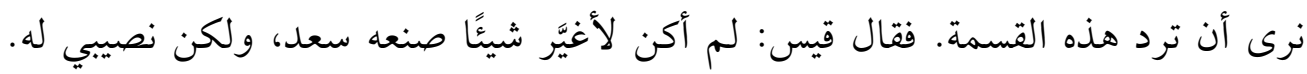

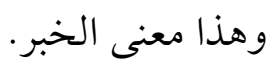

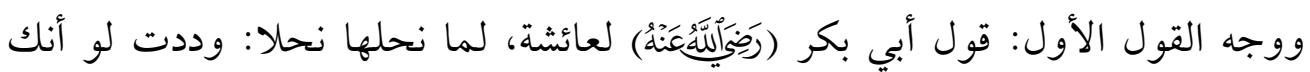
كنت حزتيه. فدل على أنها لو كانت حازته لم يكن له الرجوع. وكذلك قول عمر: لا 
وبهذا قال إسحاق(1)، وطاووس(r)، وبه قال ابن المبارك، وروي معناه

عن مجاهد، وعروة، وبه قال الحنابلة(r)، والظاهرية (ع).

القول الثالث: إذا وهبه كلَّ ماله، أو وهبه جلَّه، ولم يكن فيما استبقى ما

نحلة إلا نحلة يحوزها الولد دون الوالد.

ولأنها عطية لولده فلزمت بالموت كما لو انفرد). المغني، لابن قدامة (7/ • - - آ7).

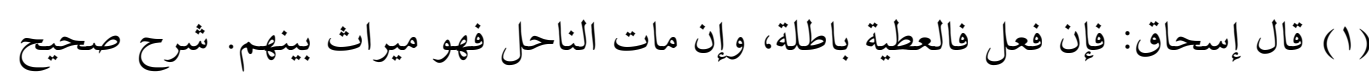

$$
\text { البخاري، لابن بطال (9^/v). }
$$

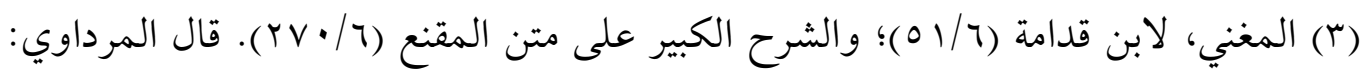

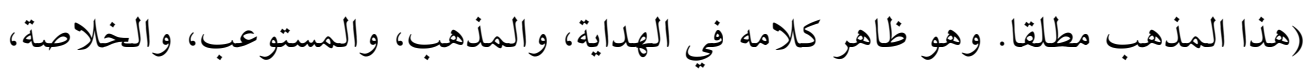

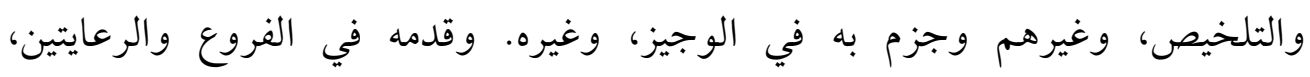

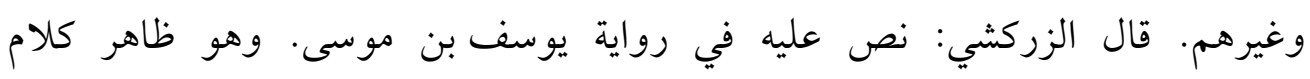

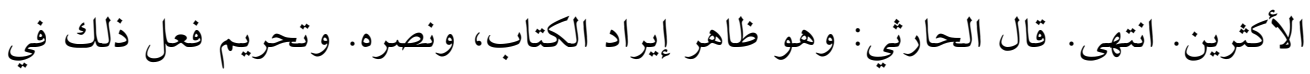

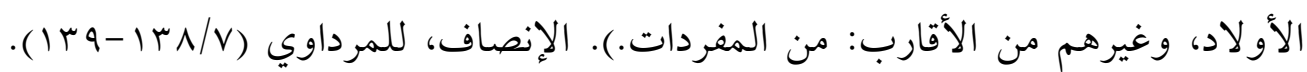

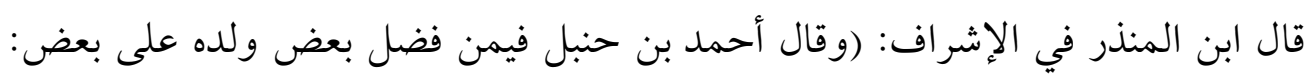

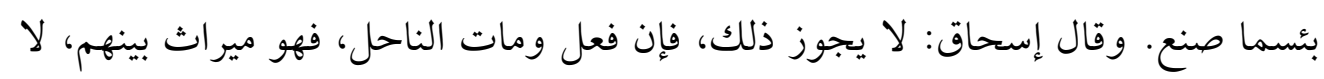

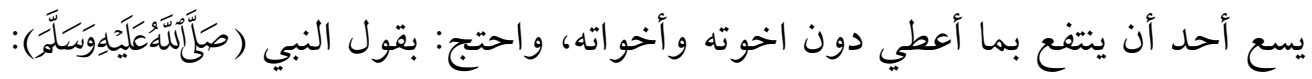
"لا تُشهدني على جور". وروينا مع ذلك عن مجاهد، وعروة، ور آه طاووس من بن أحكام

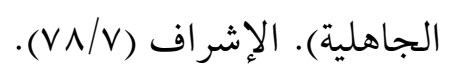

(ع) قال ابن حزم: (ولا يحل لأحد أن يهب، ولا أن يتصدق على أحد من ولده، حتى يعطي

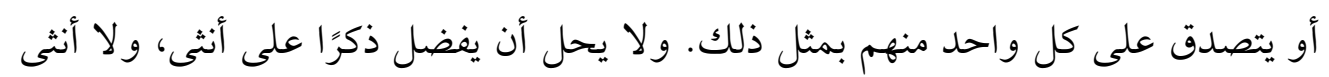

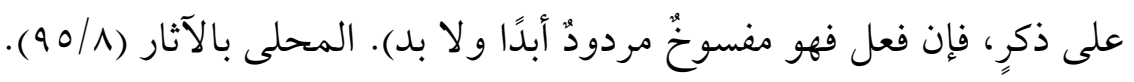


يكفيه، رُدَّت عطيته، وإن أبقى من ذلك ما يكفيه جازت. وهو محكي عن الفقيه المالكي سحنون (1) إن.

القول الرابع: أن الهبة في هذه الحالة -مع كراهتها- إذا وقعت فإنها

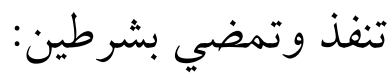
الأول: أن يحوزها الموهوب له قبل موت أو مرض الواهب. والثاني: أن لا يَمنع من ذلك باقي الأولاد في حياة والدهم، مخافة مطالبتهم بنفقة.

فإن توفر الشرطان نفذت الهبة، وإلا رُدَّتُ. وبه قال بعض المالكية (؟).

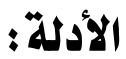

استدلَّ أصحاب القول الأول القائلون بأن العطية مع الثفضيل تقع نقع صحيحة بما يلي: - n n

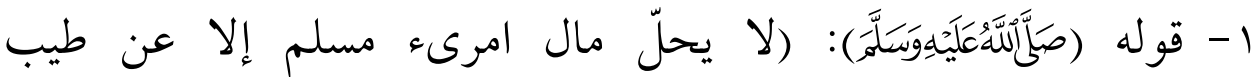

نفسه) (r)

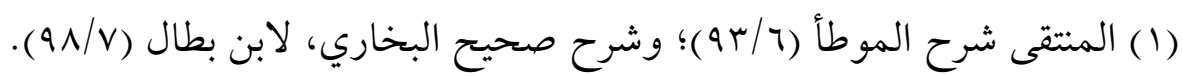

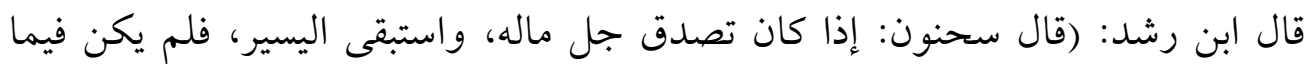

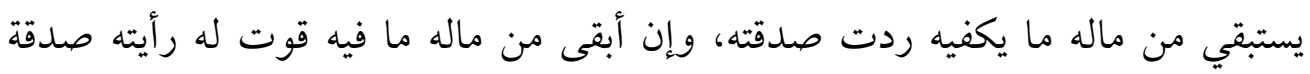

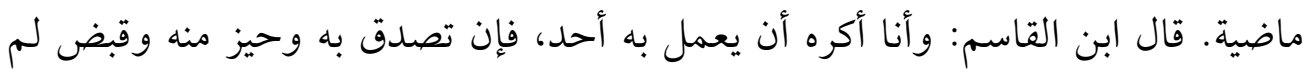

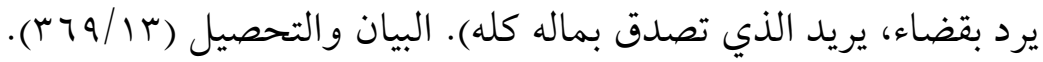

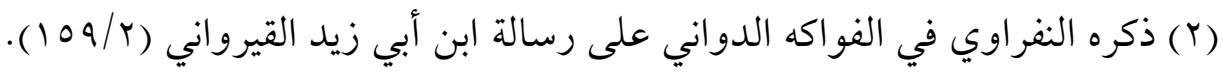
(r) الإشراف على نكت مسائل الخلاف (r) (TVo/r). 
وجه الدلالة: أن نفس الناحِل قد طابت بذلك ورضيت به، فليس هناك ما يمنع من نفاذها.

وقد يناقش هذا الاستدلال: بأن الحديث عام، مخصَّصُّ بأحاديث النهي عن التفضيل بين الأبناء في العطية.

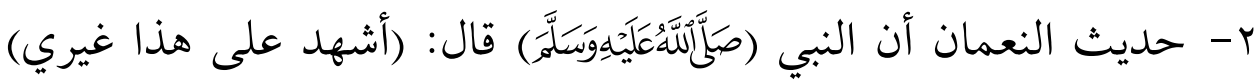

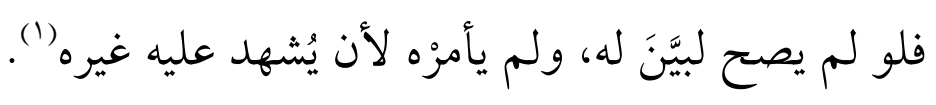

وقد يناقش هذا الاستدلال: بأن الحديث ليس لطلب الإشهاد على الحقيقة؛ إنما لبيان بطلان العمل وعدم صحته، فالأمر هنا ليس على حقيقته،

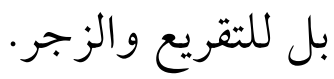

ب-- ولأن غاية ما في ذلك ترك الأفضل، كما لو أعطى لغير رَحِمِهِ وترك

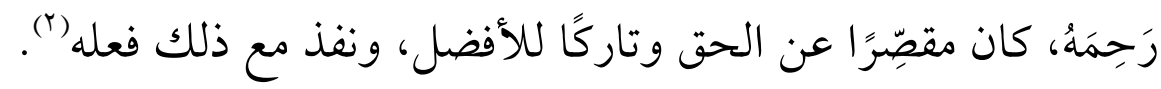
ع- ولأنه تصرف في خالص ملكه لا حقَّ لأحدٍ فيه، إلا أنه لا يكون

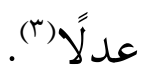
ه- ولأنه رشيدُ صحيحٌ وَهَبَ مالَه مَن لو وهبه لغيره معه لجاز، فإذا أفرده

$$
\text { به جاز، أصله إذا وهبه لأجنبي (ع). }
$$

$$
\begin{aligned}
& \text { (1) المهذب، للشيرازي (r/r/r). }
\end{aligned}
$$

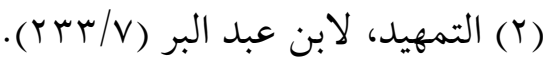

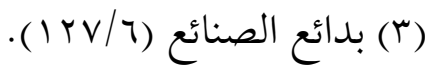

$$
\begin{aligned}
& \text { الإشراف على نكت مسائل الخلاف (T/T T/T). }
\end{aligned}
$$


1- ولأن في حال الصحة لا اعتراض لأحد عليه في ماله، وإنما

الاعتر اض حال المرض في (1).

\section{واستدل أصحاب القول الثاني القائلون ببطلان العطية بما يلي:}

1- روى عبد الرزاق في مصنفه: أن سعدَ بن عبادة، قسَّم ماله بين بنيه في

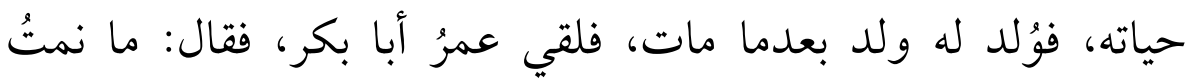

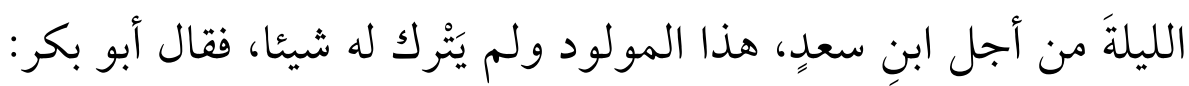

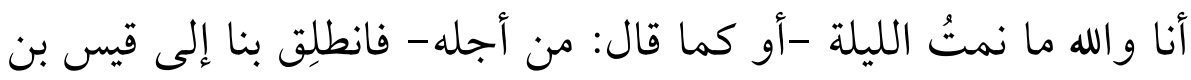

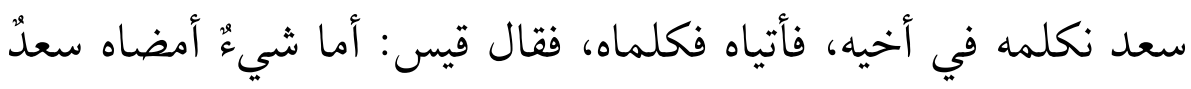

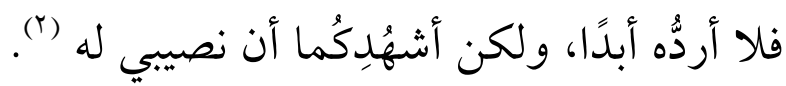

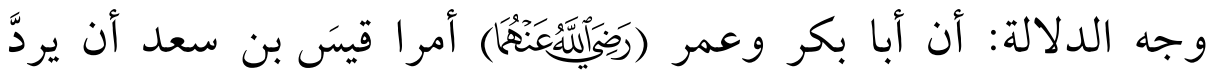

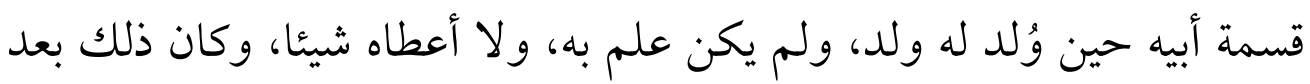

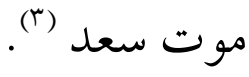

$$
\text { (1) الإشراف على نكت مسائل الخلاف (TVT/T) (TVT). }
$$

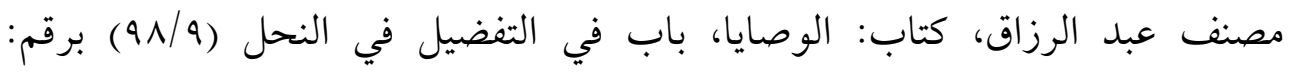

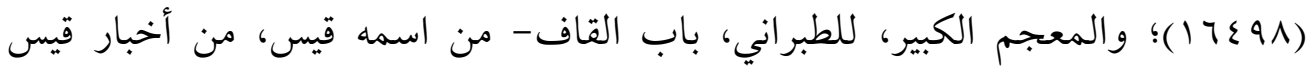
(r乞V//A)

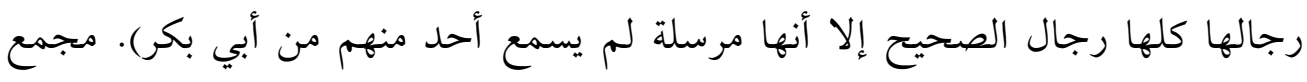

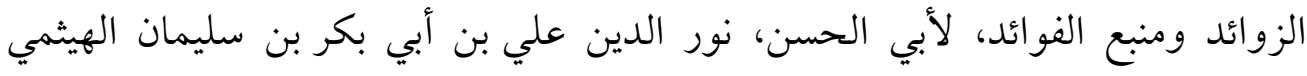

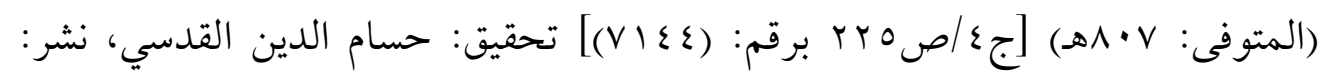

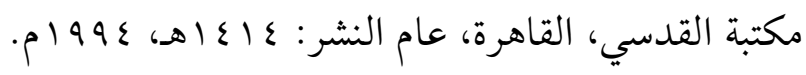

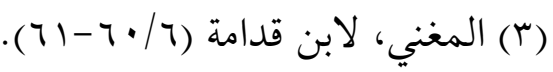


ץ- حديث النعمان بن بشير المتقدم، فقد جاء في بعض ألفاظه: (أكلَّ

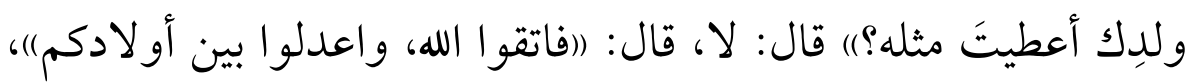

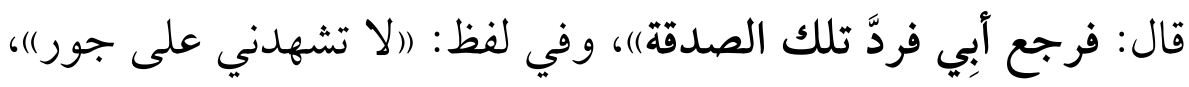

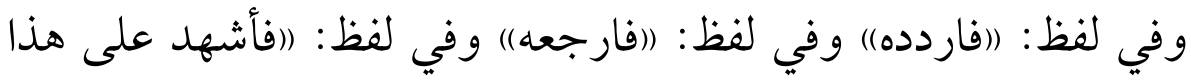
غيري") وفي لفظ: ((سو بينهم).

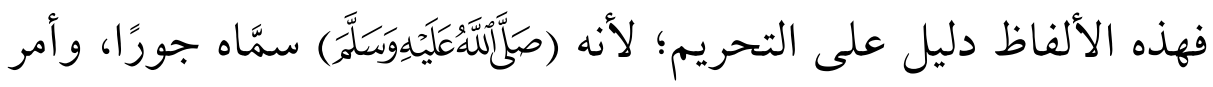

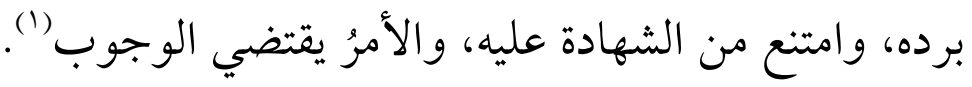

r- ولأن الجور حرام لا يحل للفاعل فعله، ولا للمعطى تناوله. والموت

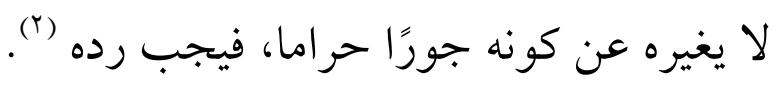
ع - ولأن تفضيل بعضهم على بعض يورث العداوةً والبغضاءً وقطيعةً

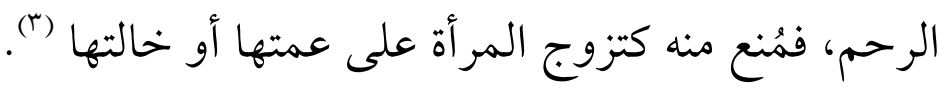

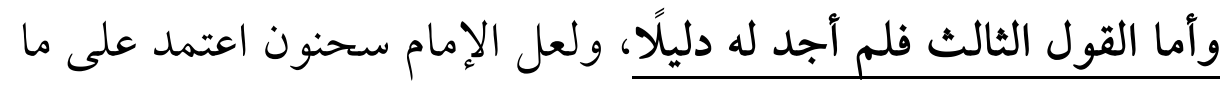

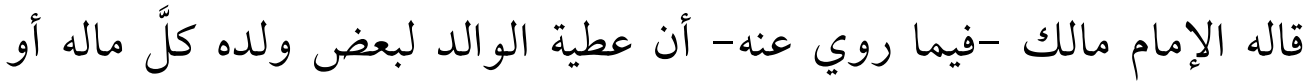
جلَّه لا تجوز، لكن لو أعطاه بعض المال كانت جائزة، وقد مرَّ معنا هذا القول بأدلته، فليراجع.

ولم أقع على أدلة لأصحاب القول الرابع أيضًا، ولعلهم استدلوا: بأن

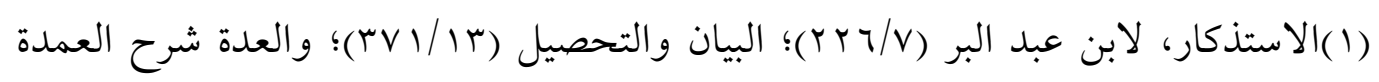

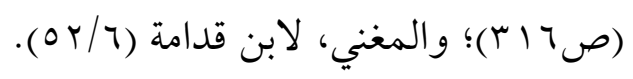
(r) المغني، لابن قدامة (T/ • (T).

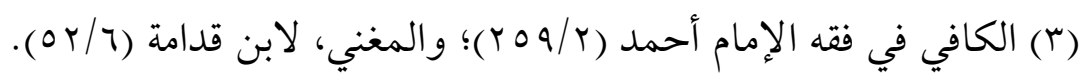


مراعاة جانب الرضا عند بقية الأولاد له تأثير على ردِّ الهبة من عدمه؛ فإنهم إن رضوا طابت نفوسهم، فيشترط رضاهم لئلا تلزمهم النفقة على أبيهم عند حاجته وافتقاره، فإذ لم يرضوا فإن عطية أبيهم ترد ولا تمضي.

\section{القول المختار، وسبب اختياره:}

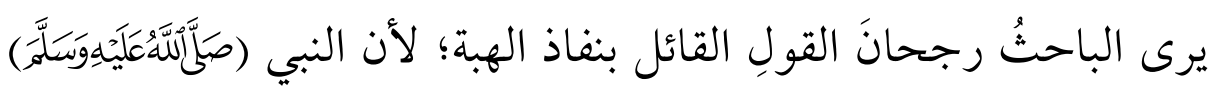
لم يصرِح ببطلانها، ولو كانت باطلة لصرَّح النبي بذلك؛ فالوقت وقت بيان،

$$
\text { وتأخير البيان عن وقت الحاجة لا يجوز. }
$$

ولا مانع من القول بالمنع منها، ثم نفاذها إن وقعت؛ فقد يكون الفعل ممنوعًا من إيقاعه، لكنه إن وقع يكون نافذًا، تترتب عليه آثاره، ويستتبع سائر

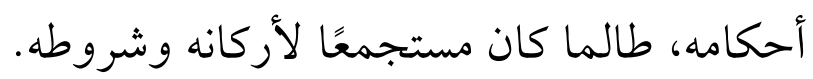

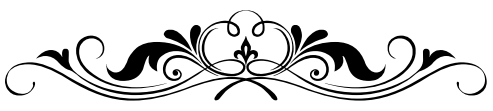




\section{المبحث السابع}

\section{هبة المال للبنات عند عدم وجود أبناءٍ ذكورٍ}

لا يخلو أمرُ البنات من حالين: إما أن يكون لهن إخوة ذكور، أو لا لإِ يكون.

فإن كان لهن إخوة ذكور، وقد فُضِّلن عليهم، فقد سبق الكلام عن هذه

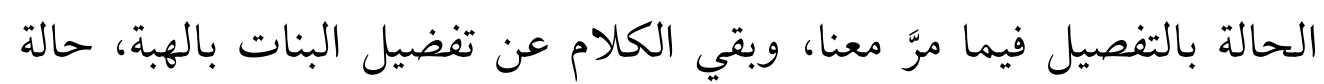
عدم وجود إخوة ذكور لهن. وقد يفعل ذلك بعض الناس، بقصد حرمان أقاربه من الميراث بعد

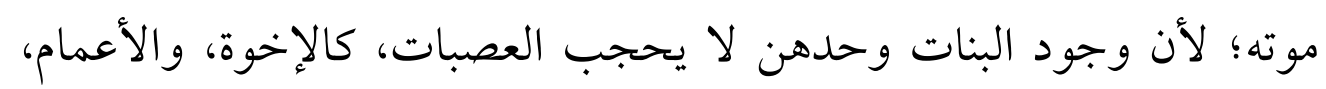

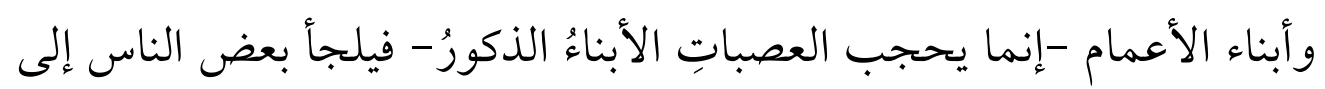
هبة ماله لبناته، أو كتابته لهن في حياته، لئلا يرث إنداء فيه عصباته من ماله شيئًا. وقد يقع ذلك الفعل من بعض الناس لا بقصد حرمان أحد من ميراثه، بل بقصد حماية البنات وتأمين مستقبلهن. وبالبحث في كتب المذاهب الفقهية، يمكننا القول بأن للفقهاء في هذه

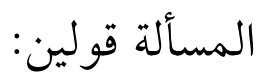

القول الأول: أن هبة المال للبنات دون بقية أرحامه جائزة؛ إذ ليس على

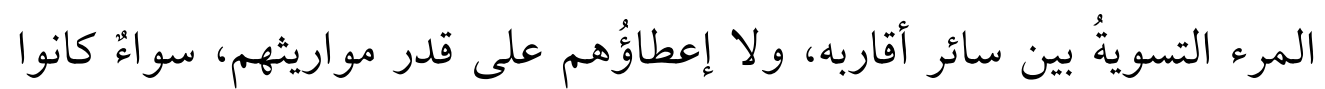

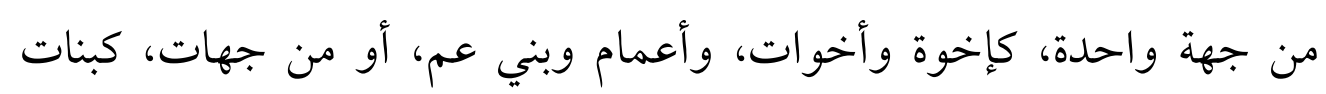

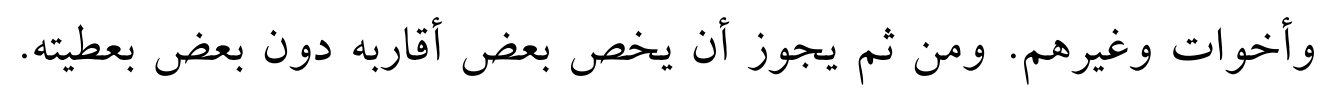


جزم به ابن قدامة في كتبه، وقال ابن مفلح: (وزعم الحارثي أنه المذهب، وأن عليه المتقدمين من أصحابنا) (1).

القول الثاني: أن تفضيل البنات بالهبة دون بقية أرحامه غير جائزة؛ لأن

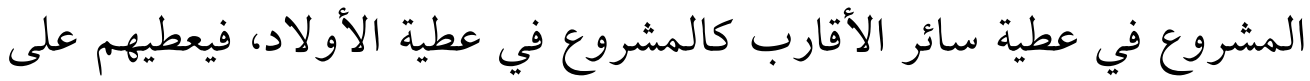

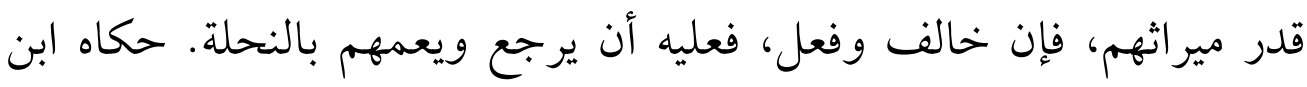

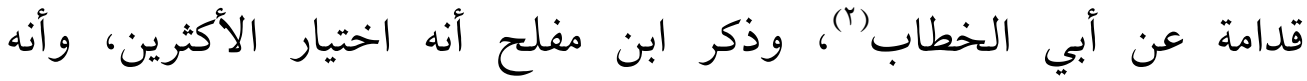

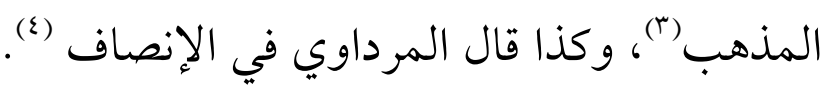

الأدلة:

\section{استدل أصحاب القول الأول القائلون بالجواز، بما يلي:}

1- لأنها عطية لغير الأولاد في صحته، فلم تجب عليه التسوية، كما لو

كانوا غير وارثين

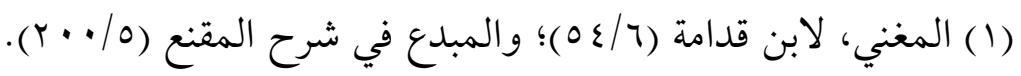

$$
\begin{aligned}
& \text { (r) المغني، لابن قدامة (T/7) }
\end{aligned}
$$

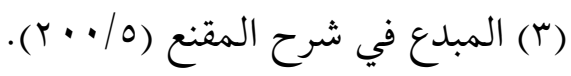

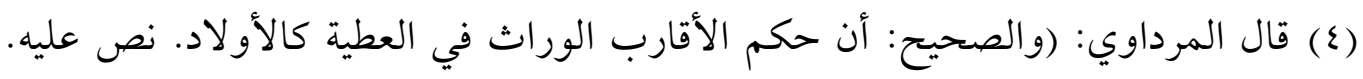

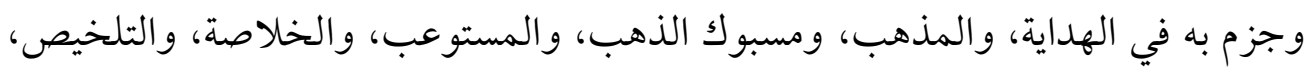

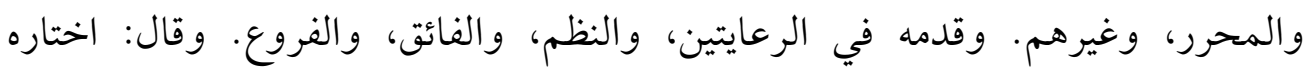

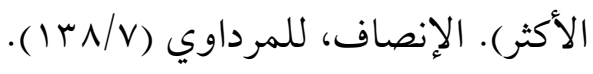

(المغني، لابن قدامة (7/ ع). 
r - ولأن كل موضع لم يلزم إعطاء الجميع، لم يحرم التفضيل (1). r- ولأن الأصل إباحة تصرف الإنسان في ماله كيف شاء، وإنما وجبت التسوية بين الأولاد بالخبر، وليس غيرهم في معناهم؛ لأنهم استووا في وجوب بر والدهم، فاستووا في عطيته. وبهذا علل النبي

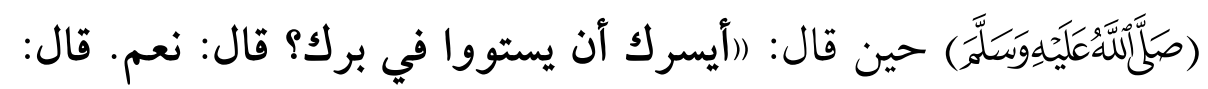

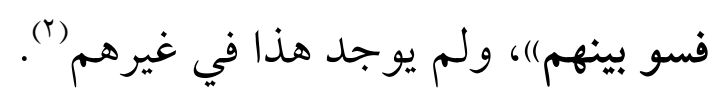
ع - ولأن للوالد الرجوع فيما أعطى ولده، فيمكنه أن يسوي بينهم باستر جاع ما أعطاه لبعضهم، و لا يمكن ذلك في غيرهم (م). 0- ولأن الأولاد لشدة محبة الوالد لهم، وصرف ماله إلئم عادة يتنافسون في ذلك، ويشتد عليهم تفضيل بعضهم، ولا يباريهم في ذلك غيرهم،

$$
\text { فلا يصح قياسه عليهم، و لا نص في غيرهم (ع). }
$$

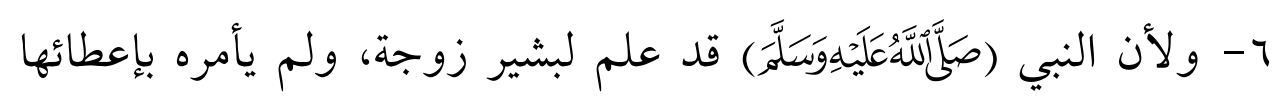

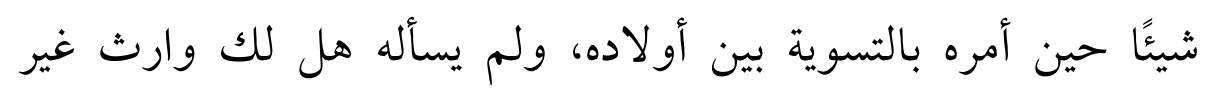

$$
\text { ولدك (0) }
$$

$$
\begin{aligned}
& \text { (1) الحاوي الكبير، للماوردي (ر/ع • (r). }
\end{aligned}
$$

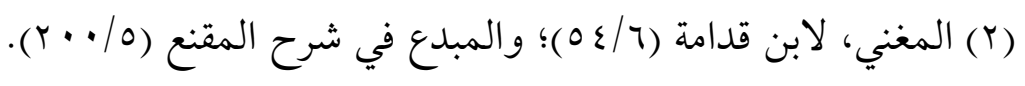

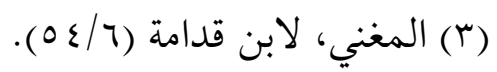

$$
\begin{aligned}
& \text { (ع) المرجع السابق نفسه. }
\end{aligned}
$$

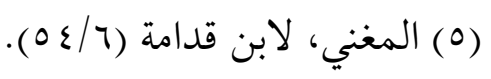




\section{واستدل أصحاب القول الثاني القائلون بالمنع، بما يلي:}

1 - أن الأقارب في معنى الأولاد، فثبت فيهم مثل حكمهم، بجامع القرابة

$$
\text { في كلٍ }
$$

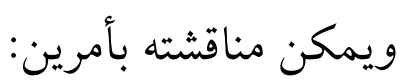

• الأول: أن هذا قياس مع الفارق؛ فالقرابة درجات متفاوتة، وليس حكم أولاده كحكم سائر أقاربه.

والثاني: أن الحديث ورد بالتسوية بين الأولاد، ولم يرد في غيرهم.

r- ولأن المنع من ذلك كان خوف قطيعة الرحم والتباغض، وهو موجود

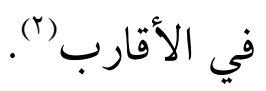

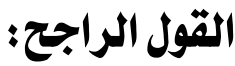

الفقه الإسلامي لا يمنع هبة المال للبنات أو لغيرهن في الأصل، فلا

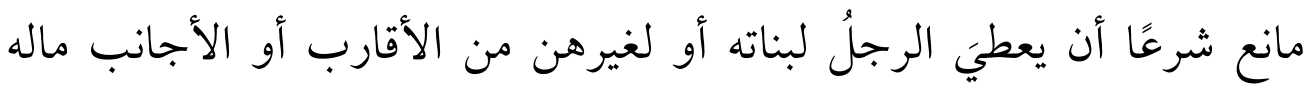

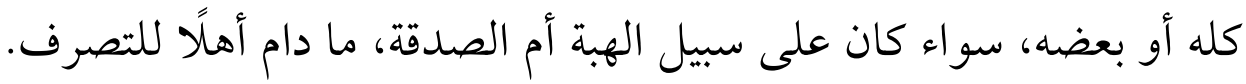
وقد قال ابن جزي: (ويجوز أن يهب الإنسان ماله كله لأجنبي اتفاقً)(").

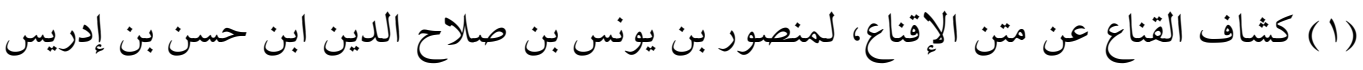

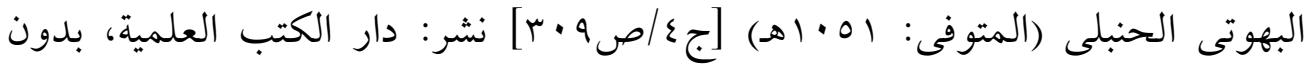

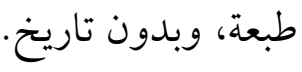

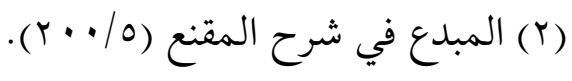

(r) القوانين الفقهية، لأبو القاسم، محمد بن (ب) أحمد بن محمد بن عبد الله، ابن جزي الكلبي 
لكن لما كان غالب حال المُقِدِمِيَّ على هذه الهبة لا يقصدون بهبتهم سوى حرمان العصبات الذكور الأقربين من أنصبائهم بعد وفاتهم، فإن الباحث يرى ترجيح القول بالجواز، لكن بضوابط وشروط ستة، وهي كما يلي:

- الشرط الأول: أن يفعل ذلك في أثناء صحته، لا في مرض موته، لئلا يُتيَّهَم بقصده حرمان بعض الورثة من أنصبائهم؛ فإن الهبة في مرضى الموت تأخذ حكم الوصية، ولا وصية لوارث(1). قال ابن المنذر: (أجمع كل من أحفظ

الغرناطي (المتوفى: I ع اهـ) [ص اع r] بدون طبعة، وبدون تاريخ. (1) قال ابن قدامة: (وحكم العطايا في مرض الموت المخوف، حكم الوصية في خمسة أشياء:

أحدها: أن يقف نفوذها على خروجها من الثلث أو إجازة الورثة. الثاني: أنها لا تصح لوارث إلا بإجازة بقية الورثة.

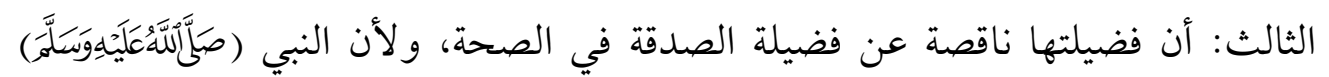
سئل عن أفضل الصدقة قال: (أن تصدق وأنت صحيح شحيح، تأمل الغنى وتخشى الفقر ولا تمهل حتى إذا بلغت الحلقوم قلت لفلان كذا، ولفلان كذا، وقد كان لفلان)، متفق عليه. ولفظه: قال رجل: يا رسول الله: أي الصدقة أفضل؟ قال: "أن تصدق وأنت

$$
\text { والرحيح حريص". أبعار: أنه يزاحم بها الوصايا في الثلث. }
$$

- أحدها: أنها لازمة في حق المعطي ليس له الرجوع فيها. وإن كثرت....بخلاف العطية في المرض، فإنه قد وجدت العطية منه، والقبول من المعطي، والقبض، فلزمت كالوصية 
عنه من أهل العلم، أن حكم الهبات في المرض الذي يموت فيه الواهب،

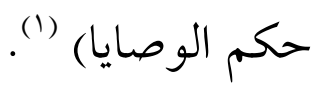

- وقال ابن عبد البر في التمهيد: (فعل المريض في ماله وصية؛ والوصية للوارث باطلة، وهذا أمر مجتمع عليه، يستغنى عن القول فيه) (r).

$=$

إذا قبلت بعد الموت وقبضت.

- الثاني: أن قبولها على الفور في حال حياة المعطي، وكذلك ردها، والوصايا لا حكم

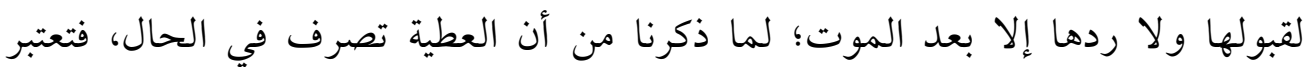
شروطه وقت وجوده، والوصية تبرع بعد الموت، فاعتبر شروطه بعد الموت.

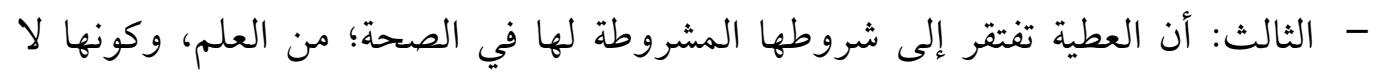
يصح تعليقها على شرط وغرر في غير العتق، والوصية بخلافه.

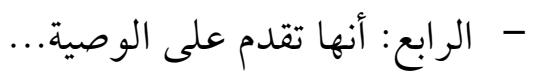
- الخامس: أن العطايا إذا عجز الثلث عن جميعها، بدئ بالأول فالأول........ - السادس: أن الواهب إذا مات قبل تقبيضه الهبة المنجزة، كانت الخيرة للورثة، إن شاءوا

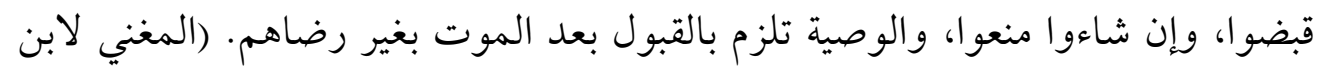

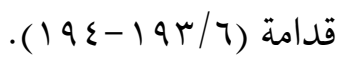

الإشراف على مذاهب العلماء، لأبي بكر، محمد بن إبراهيم بن المنذر النيسابوري

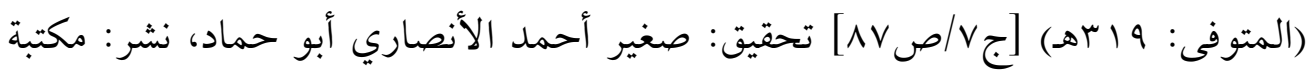

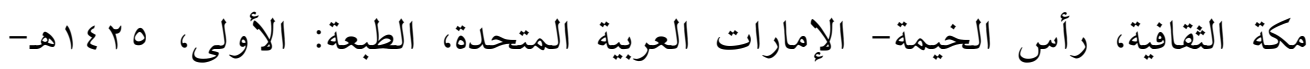

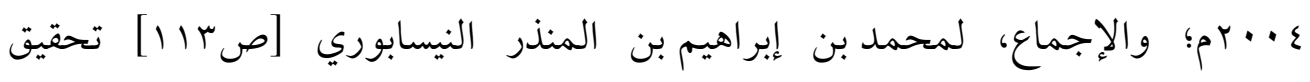

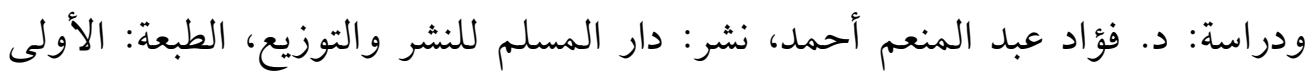

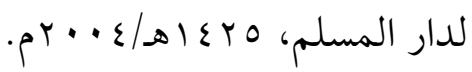

$$
\begin{aligned}
& \text { (r) التمهيد، لابن عبد البر(Y)/V) }
\end{aligned}
$$


- الشرط الثاني: أن يسوِيَّ بين بناته في الهبة، فلا يفضل واحدةً على أخرى، وقد سبت الكلام تفصيلًا عن حكم التفضيل.

- الشرط الثالث: أن يرفع يده عن هذا المال فور الهبة، بحيث يتصرف فيه فيه

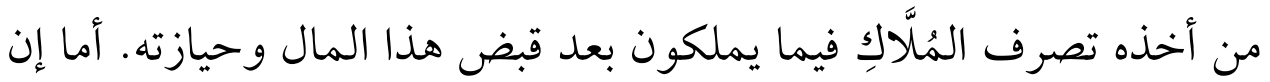
ظل هذا المال في يده، ولم يتمكن البنات (الموهوب لهن) من حيازته وقبضه، فإنه قد خرج عن نطاق الهبة، وصار عقد وصية، يأخذ حكم الوصية، فلا ينفذ؛ لظهور قصده بياضرار الغير، وقد قال النبي

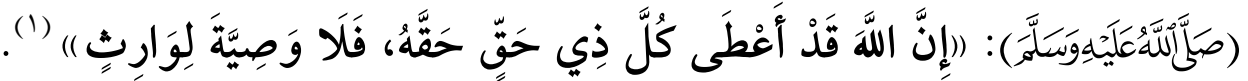

(1) صحيح: رواه عبد الرزاق في المصنف، وأبو داوود في السنن: مصنف عبد الرزاق،

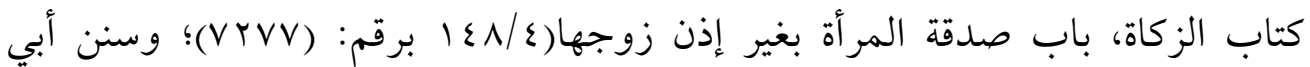
داود، لأبي داود، سليمان بن الأشعث بن إسحاق بن بشير بن شداد بن بـ عمرو الأزدي

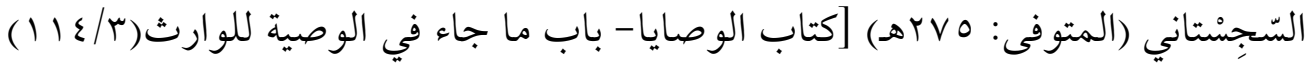

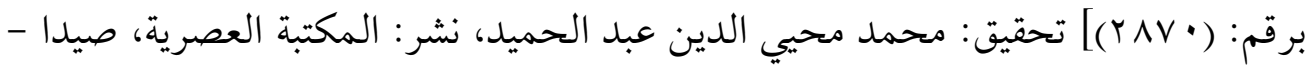
بيروت، بدون طبعة، وبدون تاريخ.

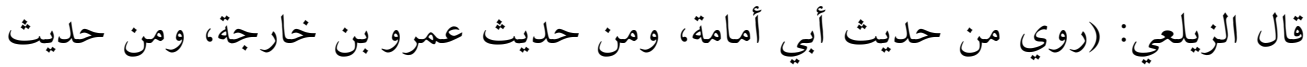

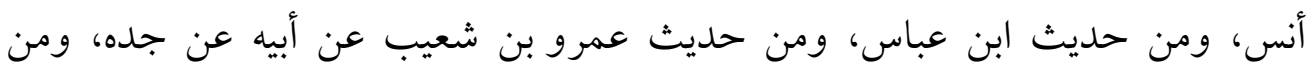

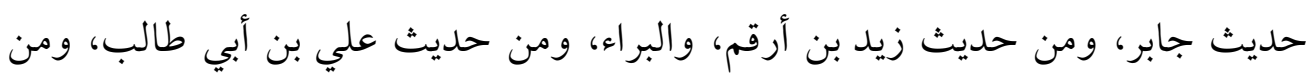

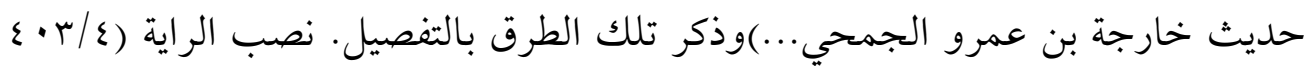
وما بعدها).

وذكر ابن الملقن أن هذا الحديث قد اشتُهِرَ شهرةً يستغني بها عن الإسناد. ينظر: البدر

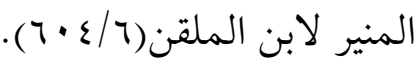
وقد أطال ابن الملقن ذكر طرق هذا الحديث إلى أن قال: (قد تقرر لك من ثلاثة أوجه $=$ 
- الشرط الرابع: ألا يقصد بهذا التصرف حرمان الورثة من نصيبهم؛ فلا يجوز للواهب أن يقصد بهبته أو وصيته حرمان بعض الورثة، فإن ذلك من إن إن

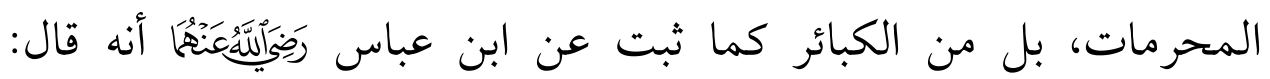

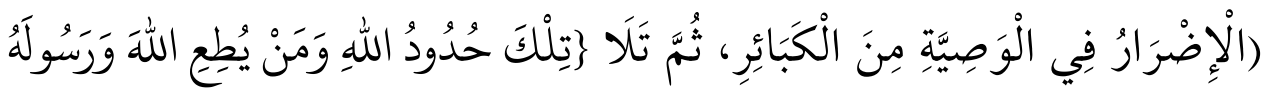

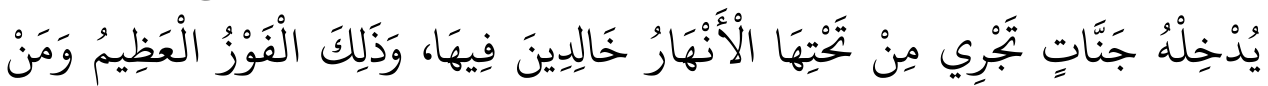

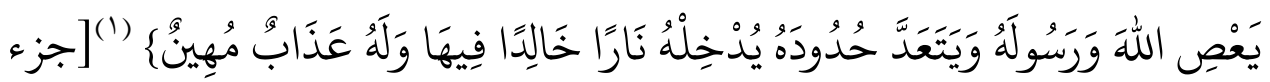

قوته، وعبارة الشافعي في ((الأم)): ورأيت متظاهرًا عند عامة من لقيت من أهل العلم

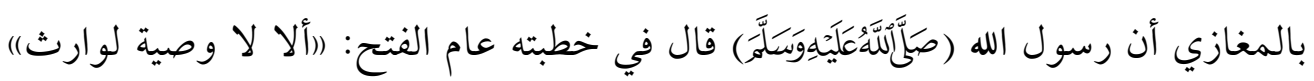

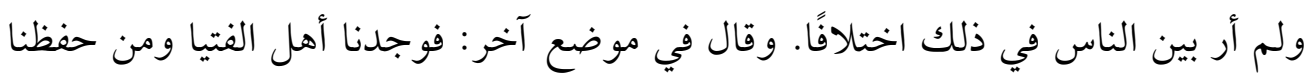

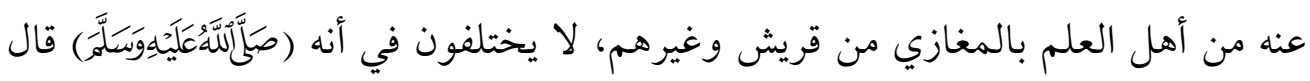

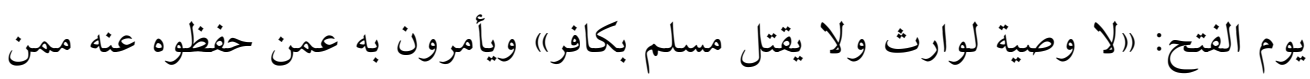

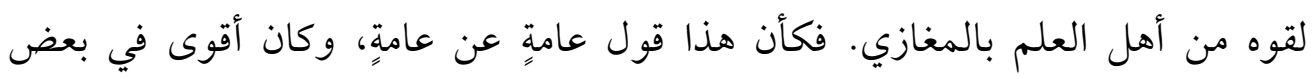

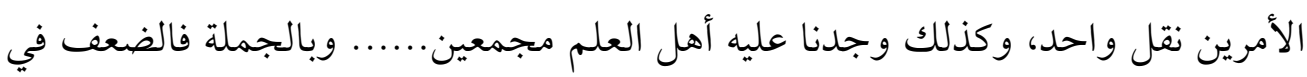

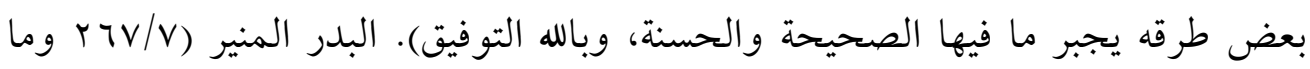
بعدها).

صحيح موقوفًا على ابن عباس: السنن الكبرى، لأبو عبد الرحمن أحمد بن شعيب بن

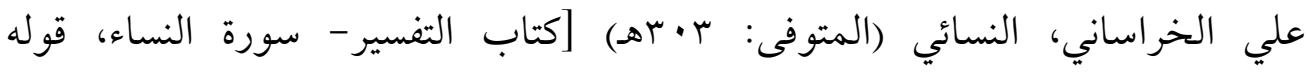

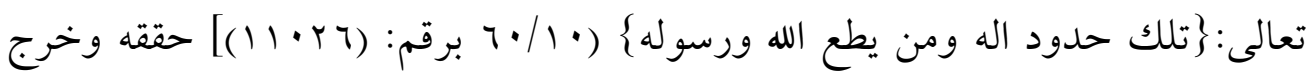

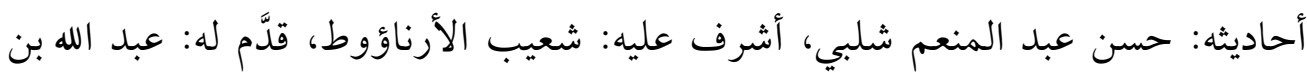

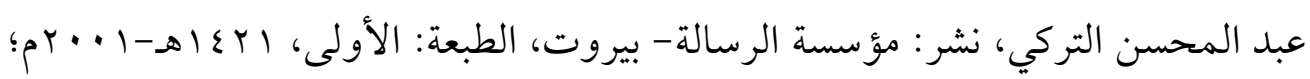

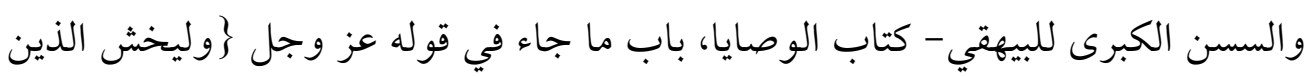

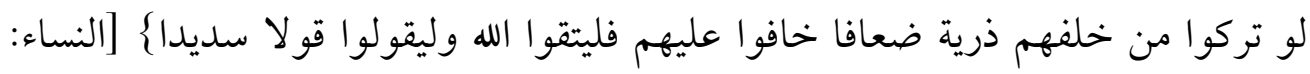


من الآية (ع (1) من سورة: النساء]. إذ التركة حقهم الذي فرضه الله سبحانه

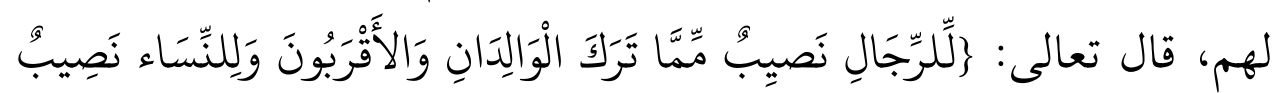

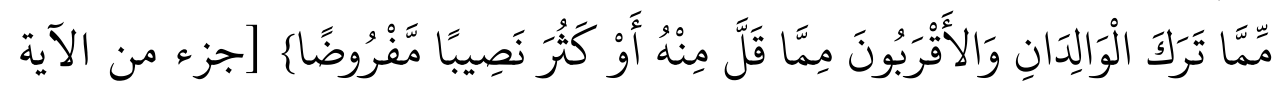
(V) من سورة: النساء]. فإن فعل فهو ظالم لهم؛ لأن هذا من الحيل المحرمة، وقد ورد عن محمد بن الحسن تلميذ أبي حنيفة رحمهما الله أنه قال: ليس من أخلاق المؤمنين الفرار من أحكام الله بالحيل الموصلة إلى (1) إبطال الحق) وإن زعم أن سبب هبته لبناته خوفه عليهن وحرصه على مستقبلهن، فحرصه على آخرته وخوفه من خالقه يجب أن يكون أولى عنده بالاعتبار و العناية و المر اعاة.

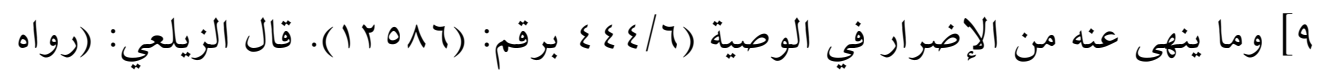

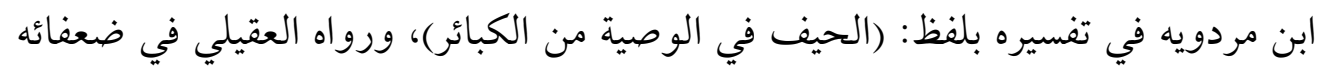

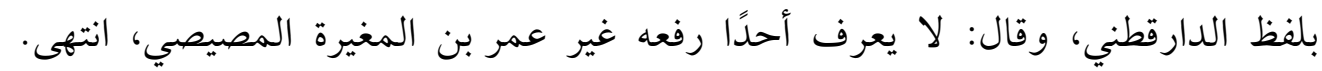

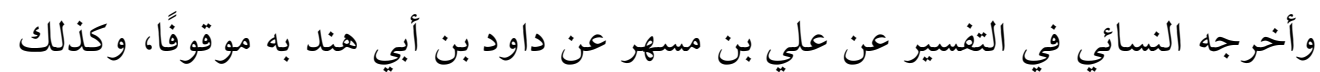

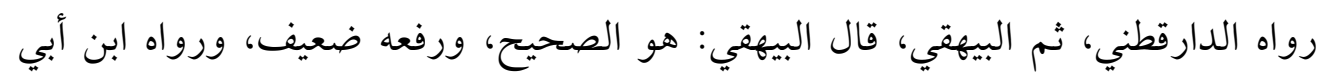

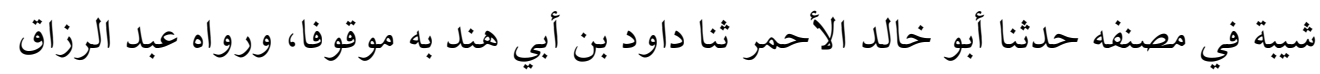
في مصنفه أخبرنا الثوري عن داود بن أبي هند موقوفا، وزاد: ثم تلا:

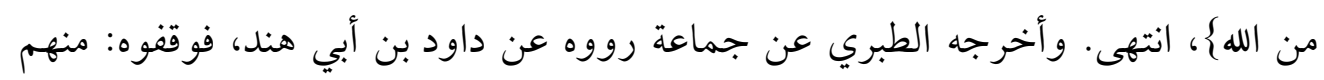

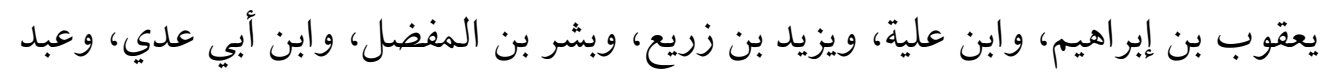

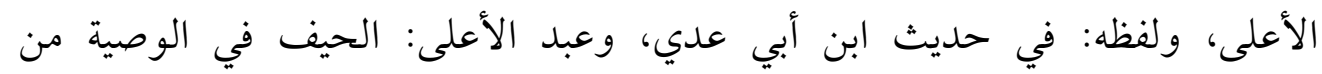

$$
\begin{aligned}
& \text { الكبائر ا، وفي الباقي: الضرار). نصب الراية (ع/Y ••ع). } \\
& \text { عمدة القاري شرح صحيح البخاري (ع ب/9 • (1). }
\end{aligned}
$$


- الشرط الخامس: ألا يوقعه هذا التصرف في الحرام من سؤال الناس، والتسخط على أقدار الله، وتضييع من تلزمه نفقتهم، وقد ورد أن سعد بن

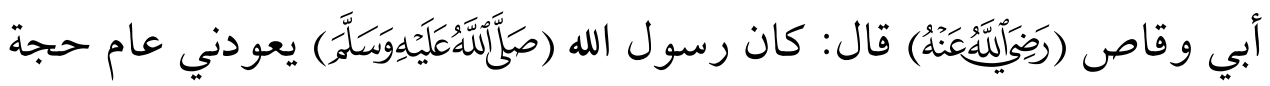
الوداع من وجعٍ اشتدَّ بي، فقلت: إني قد بلغ بي من الوجع وأنا ذو مالٍٍ،

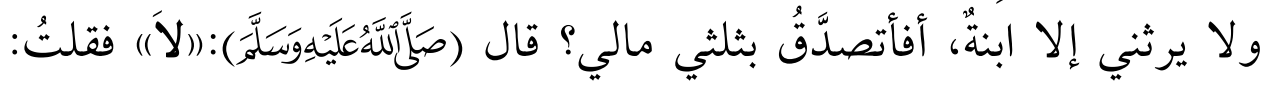

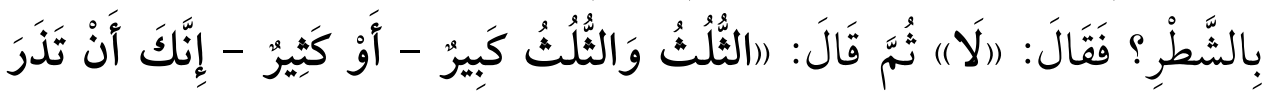

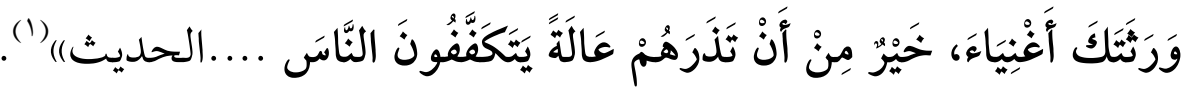
- الشرط السادس: أن لا يهبهن جميع ماله، بل يستبقي منه ما يكفيه ويسد حاجته وحاجة من يلز مه؛ لأن حر صه على مستقبل بناته وخوفه عليهن لا ينبغي أن يدعوَه للتنصل من التزاماته والتفلُّتِ من بقية واجباته، وقد وقد قال

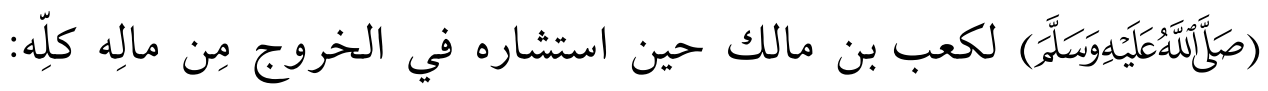

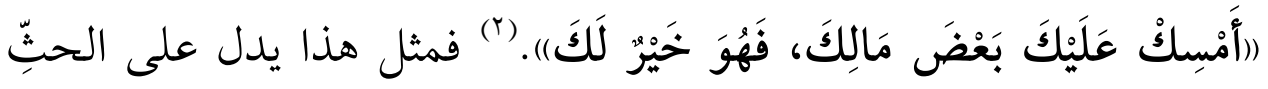
على أن يُبقيَي المالك لنفسه عند الصدقة أو الهبة أو الإنفاق في سبيل الله (1) متفق عليه، واللفظ للبخاري؛ صحيح البخاري- كتاب الجنائز، باب: رثاء النبي

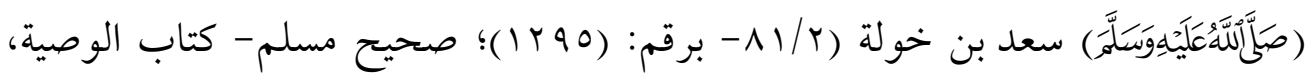

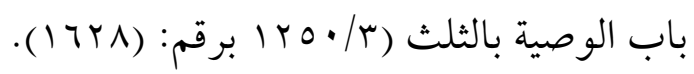

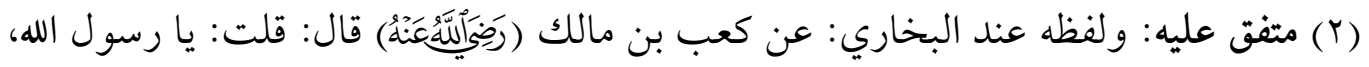

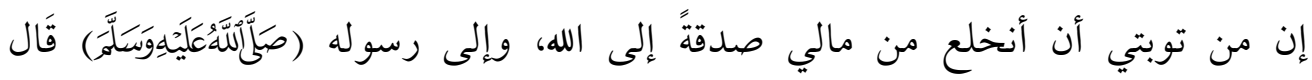

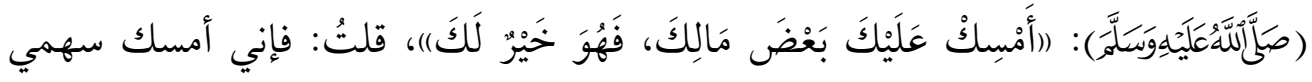

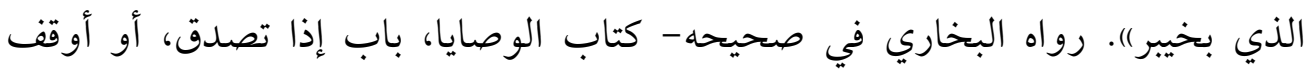

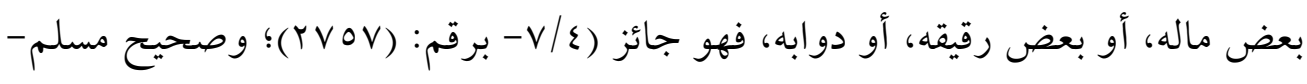

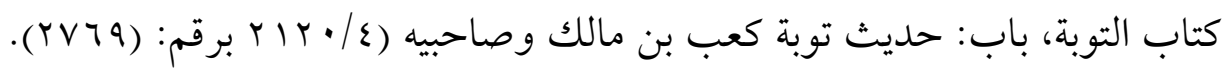


بعضًا من ماله يقيم به حياته، وحياة من يعول، ويهيئ له معاشًا يمنعه ذل السؤال والحاجة إلى الناس.

ومن دواعي هذا الشرط أيضًا: أن يُبقيَ لورثته الآخرين من بعده شيئًا.

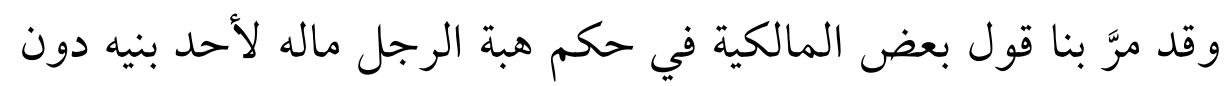

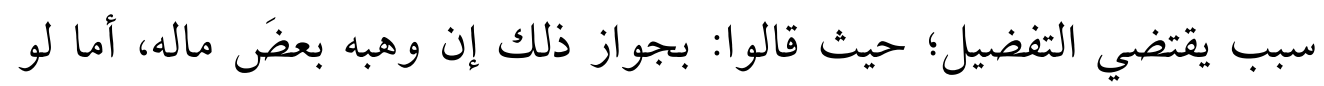

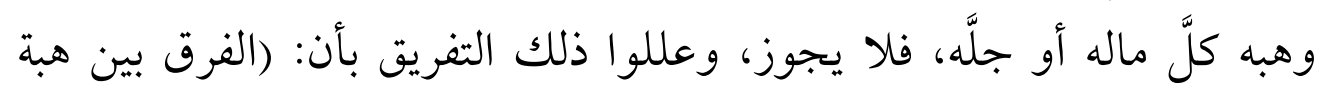

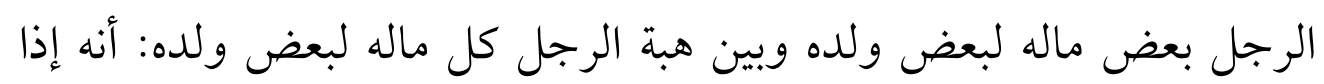

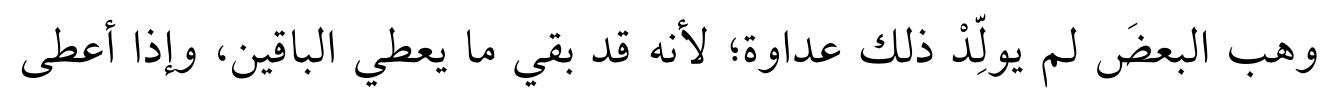

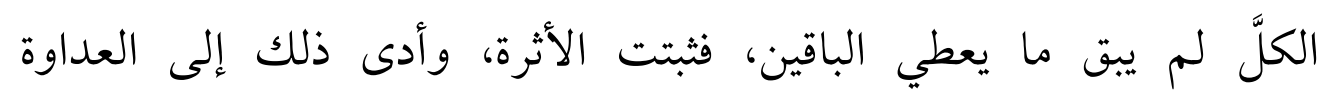

والبغضاء)(')

ومثل هذا يقال في مسألتنا، فَيَهَبُ لبناته، لكن لا يستأصل كلَّ ماله لهذا

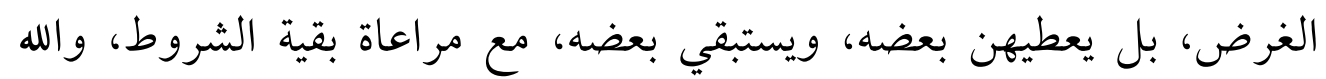

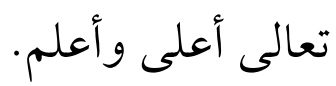

فإن تحققت هذه الشروط الستة، فلا بأس ببذل المال للبنات، أما إذا لم تتحقق كلها، فيُمنع الو الد من ذلك.

وقد جاء في الفتاوى المهدية للشيخ: محمد المهدي العباسي [شيخ

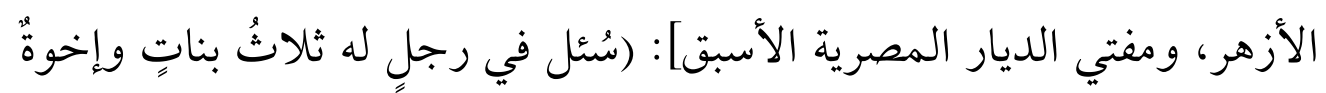

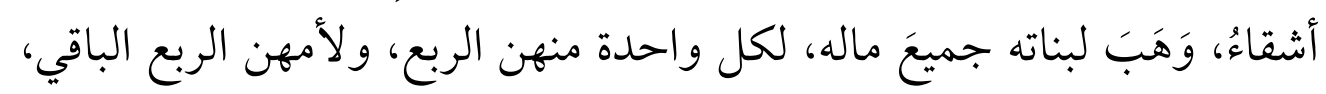

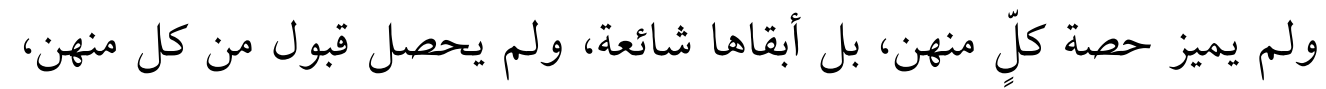


والبنات المذكورات بالغات، وصار المذكور يتصرف في ماله وفي المنزل الذي من جملة الموهوب، وقصده حرمان بقية الورثة، فهل الهبة صحيحة أم

أجاب: الهبة على الوجه المذكور غير تامة، والله تعالى أعلى وأعلم)(1). فيلاحظ أن الشرطين الثالث والرابع غيرُ محققين؛ حيث إن الأب لم يرفع يده عن الهبة لتتحقق الحيازة والقبض للموهوب لهن، وهذه قرينة ظاهرة على أنه قصد بفعله حرمان بقية الورثة من حقهن، ولذلك كانت الفتوى بعدم صحة الهبة وعدم تمامها. ومن فتاوى الشيخ/جاد الحق على جاد الحق (شيخ الأزهر السابق) ما ورد جوابًا عن سؤ ال ما نصه: (اطلعنا على الطلب المقدم من السيد (م سعد)، المتضمن: أن السائل يريد بيان حكم الشرع في المسألة التالية: سيدة عندها أولاد بنات، عددهن ثلاثة، وليس لها أولاد سواهن، ولكن لها أخ شقيق، ولها أولاد أخت شقيقة- وهذه السيدة تريد أن تكتب جميع ممتلكاتها لبناتها الثلاث بالتساوي بينهن، فهل يجوز لها ذلك شرعًا أم لا؟ الجواب: أنه لما كان الأصل إباحة تصرف الإنسان في ماله كيف شاء مادام عاقلًا بالغًا في صحته غير سفيه ولا مبذر ولا متلف للمال في غير ما أحله الله، كان لهذه السيدة أن تتصرف في مالها حسبما أرادت إذا كانت بهذه الأوصاف الرشيدة، فقد نص الفقهاء على أنه: ليس على الإنسان التسوية بين سائر أقاربه ولا إعطاؤهم على قدر مواريثهم، سواء أكانوا من جهة واحدة 
كأخوة وأخوات وأعمام وبنى عم أو من جهات، كبنات وأخوات وغيرهم؛ لأن هذه عطية لغير الأولاد في الصحة، فلم تجب التسوية كما لو كانوا غير وارثين، ولأن التسوية وردت في شأن الأولاد دون غيرهم من ذوى القربى. نص على هذا في المغنى لابن قدامة الحنبلي في باب الهبة)(').

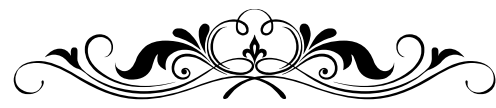

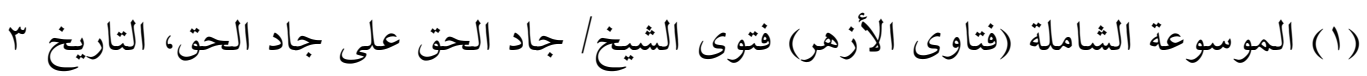

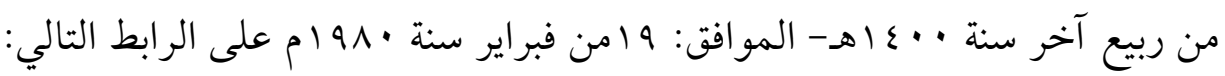
http://islamport.com/d/2/ftw/1/11/500.html 


\section{الخاتمـة}

أحمد لله تعالى الذي وفقني وأعانني لإتمام هذا البحث، والذي خلصت فيه إلى النتائج التالية: - 20 - 20

1 - الهبة تصرف ينعقد وينفذ حال حياة الواهب وصحته، أما إذا كان في مرض الموت فإنه يأخذ أحكام الوصية، ولا وصية لوارث. r- استدامة الؤدُّ والألفةُ ونزع أسباب التباغض والشحناء بين أبناء المجتمع بشكل عام، وبين أبناء الأسرة الواحدة بشكل خاص، مقصد من مقاصد الشريعة، يجب اعتباره، والعمل على إزالة ورفض كل ما من شأنه زعزعته أو اختلاله.

r- للفقهاء قولان في حكم تفضيل الوالد لأحد أبنائه بعطية لسبب يقتضي التفضيل، كفقر أو مرضِ ...إخخ، ورجحتُ القول القائل بالجواز؛ لأنه فيه جمعًا بين الأدلة الواردة في المسألة، وفيه تحقيق لقواعد المساواة بين الأبناء، بتعويض من قام به سبب نقص ليتساوى مع بقية أقرانه، و مثل هذا الإنصاف لا تأباه الشريعة ولا تنكره.

ع- القول الراجح في تفضيل الولد الذي عمل في مال أبيه، وكان سبيًا في تنميته وتكثيره، (الجواز)؛ لأن له أجر العامل، طالما تأثر المال بعمله من حيث النماء والربح والزيادة، ويُرجَعُ في تقدير أجرِهِ -عند التنازعإلى أهل الخبرة، هذا إذا لم يتفق الأب وابنه من بداية العمل أن ما حصَّلاه من كسب فهو بينهما، فعند حصول هذا الاتفاق، يكون الأمر على ما اشترطا. 


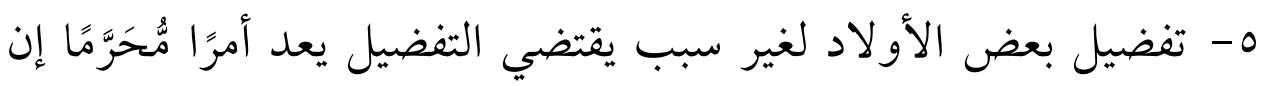

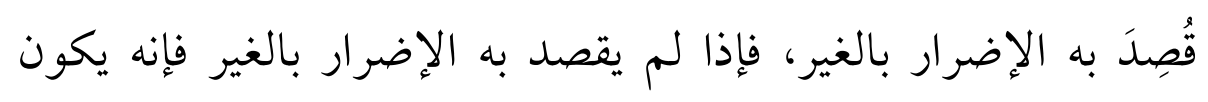

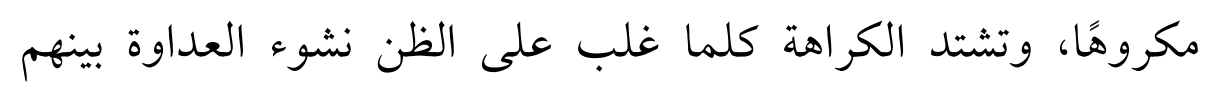

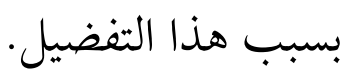

7- كيفية التسوية بين الأبناء في العطية أن تُعَى الأنثى مثلما يُعطَى الذكر،

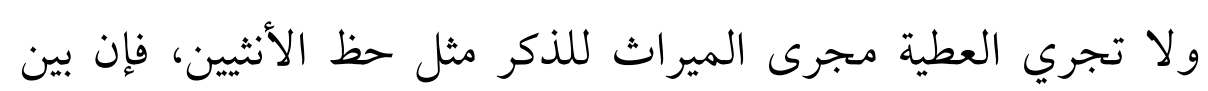

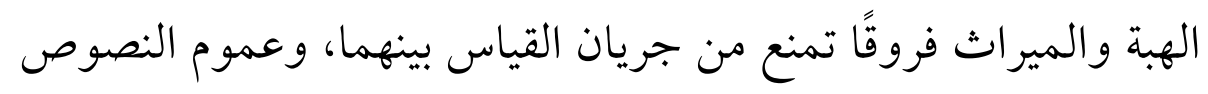
الواردة في المسألة يؤيد هذه الكيفية ويعضدها. V- الهبة مع التفضيل الممنوع، تنفذ وتمضي؛ لأن الأحاديث صرَّحت بالمنع، لكنها لم تصرِّخْ بالبطلان.

1- هبة المال للبنات دون بقية الأقارب -لمن لم ينجب ذكورًا- جائزة،

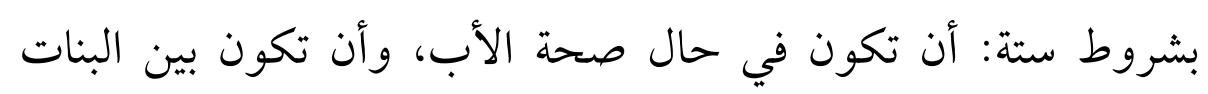

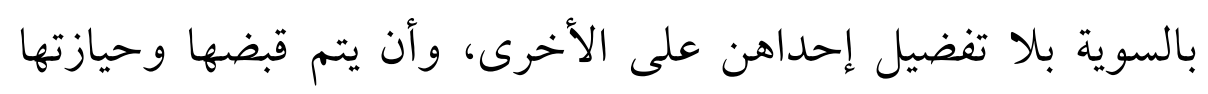

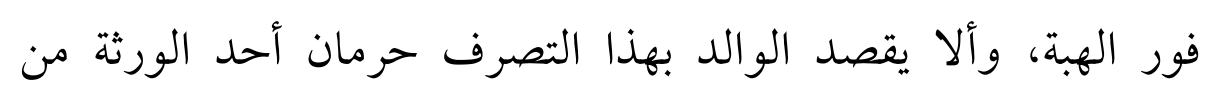

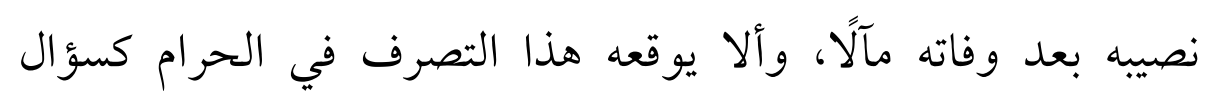

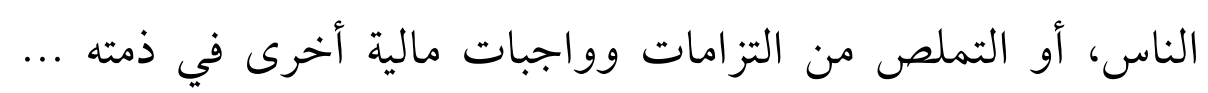
إلخ، وإلا تكون الهبة مستغرقة جميع المال.

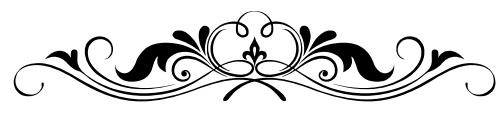




\section{ثبت بأهم مصادر البحث}

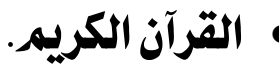

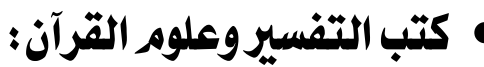

- أوضح التفاسير، لمحمد محمد عبد اللطيف بن الخطيب (المتوفى: ب + ع اهـ) نشر: المطبعة المصرية ومكتبتها، الطبعة: السادسة، رمضان سمیر اهـ - فبراير

r- الجامع لأحكام القرآن = تفسير القرطبي، لأبي عبد الله، محمد بن أحمد بن

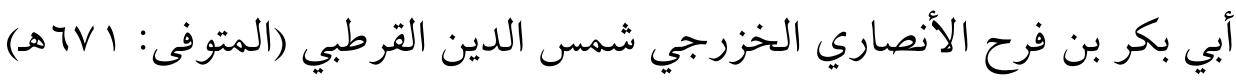

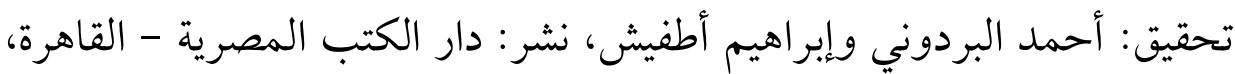

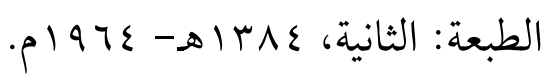

r- اللباب في علوم الكتاب، لأبو حفص سراج الدين عمر بن علي بن عادل

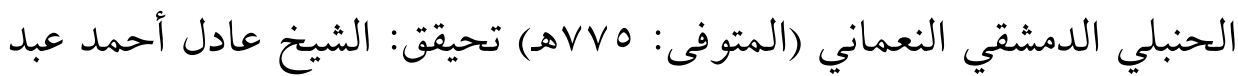

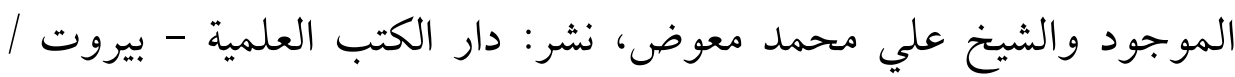

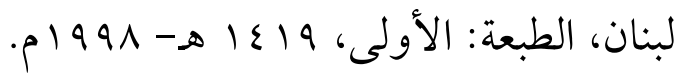
ع- المحرر الوجيز في تفسير الكتاب العزيز، لأبي محمد، عبد الحق بن غالب بن

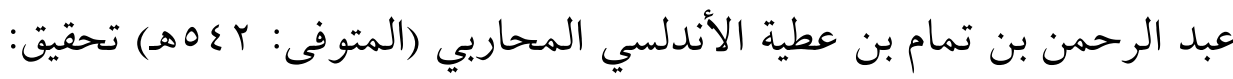
عبد السلام عبد الشافي محمد، نشر: دار الكتب العلمية - بيروت، الطبعة:

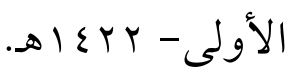

\section{كتب السنة ، وشروحها :}

ه- إرشاد الساري لشرح صحيح البخاري، لأحمد بن محمد بن أبى بكر بن عبد الملك القسطلاني القتيبي المصري، أبو العباس، شهاب الدين (المتوفى: 
بr9هـ نشر : المطبعة الكبرى الأميرية، مصر، الطبعة: السابعة، سب باهـ. 7- الاستذكار، لأبي عمر، يوسف بن عبد الله بن محمد بن عبد البر بن عاصم النمري القرطبي (المتوفى: با7عه) تحقيق: سالم محمد عطا، محمد علي معوض، نشر: دار الكتب العلمية - بيروت، الطبعة: الأولى، ابكأهـ pr...

V- البدر المنير في تخريج الأحاديث والأثار الواقعة في الشرح الكير، لابن الملقن سراج الدين أبو حفص عمر بن علي بن أحمد الشافعي المصري (المتوفى: ع • هـ) تحقيق: مصطفى أبو الغيط وعبد الله بن سليمان وياسر بن كمال، نشر: دار الهجرة للنشر والتوزيع - الرياض -السعودية، الطبعة: الاولى، Pr. 1- التمهيد لما في الموطأ من المعاني والأسانيد، لأبو عمر يوسف بن عبد الله بن محمد بن عبد البر بن عاصم النمري القرطبي (المتوفى: سا7عه) تحقيق: مصطفى بن أحمد العلوي، محمد عبد الكبير البكري- نشر: وزارة عموم الأوقاف والشؤون الإسلامية - المغرب، عام النشر : بV اهـ. ه - جامع الأصول في أحاديث الرسول، لمجد الدين أبو السعادات المبارك بن محمد بن محمد بن محمد ابن عبد الكريم الشيباني الجزري ابن الأثير (المتوفى: 7 ·7هـ) تحقيق: عبد القادر الأرنؤوط - التتمة تحقيق بشير عيون، نشر: مكتبة الحلو اني - مطبعة الملاح - مكتبة دار البيان- الطبعة: الأولى.

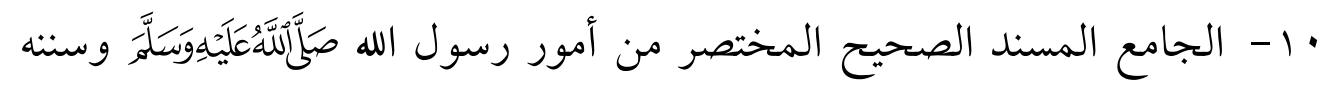
وأيامه = صحيح البخاري، لمحمد بن إسماعيل أبو عبداله البخاري الجعفي- تحقيق: محمد زهير بن ناصر الناصر- نشر: دار طوق النجاة (مصورة عن السلطانية بإضافة ترقيم ترقيم محمد فؤاد عبد الباقي) الطبعة: 


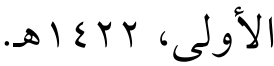

11 - سبل السلام، لمحمد بن إسماعيل بن صلاح بن محمد الحسني، الكحلاني ثم الصنعاني، أبو إبراهيم، عز الدين، المعروف كأسلافه بالأمير (المتوفى: r/11 اهـ) نشر : دار الحديث، بدون طبعة ويدون تاريخ. rا - سنن أبي داود، لأبي داود، سليمان بن الأشعث بن إسحاق بن بشير بن

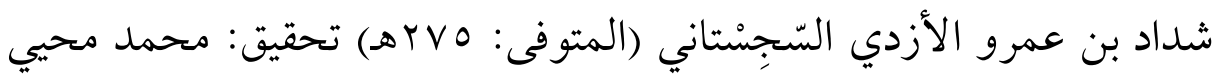
الدين عبد الحميد، نشر: المكتبة العصرية، صيدا - بيروت، بدون طبعة، وبدون تاريخ. rا - سنن الترمذي، لمحمد بن عيسى بن سَوْرة بن موسى بن الضحاك، الترمذي،

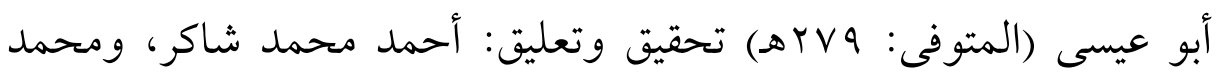
فؤاد عبد الباقي، وإبراهيم عطوة عوض، نشر: شركة مكتبة ومطبعة مصطفى

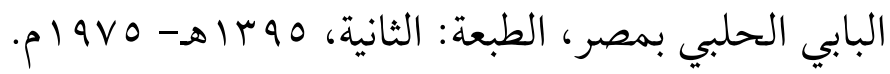
ع ا- السنن الكبرى، لأبو عبد الرحمن أحمد بن شعيب بن علي الخراساني، النسائي (المتوفى: ب. rهـ) حققه وخرج أحاديثه: حسن عبد المنعم شلبي، أشرف عليه: شعيب الأرناؤوط، قدَّم له: عبد الله بن عبد المحسن التركي،

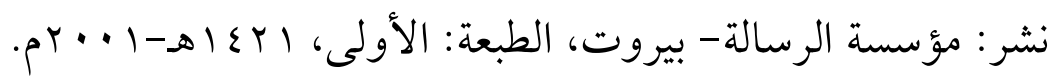
1 - السنن الكبرى، لأحمد بن الحسين بن علي بن موسى الخُسْرَوْجِردي

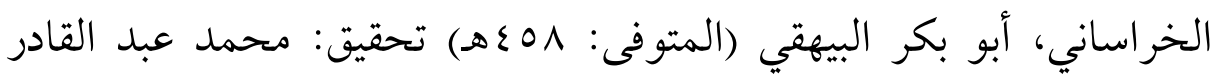

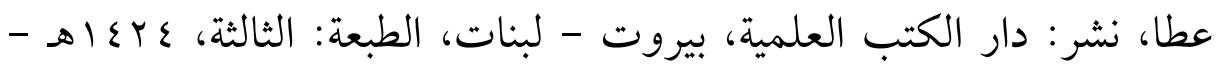

$$
\text { pr..r }
$$

17 - شرح الزرقاني على موطأ الإمام مالك، لمحمد بن عبد الباقي بن يوسف الزرقاني المصري الأزهري، تحقيق: طه عبد الرؤوف سعد، نشر: مكتبة 


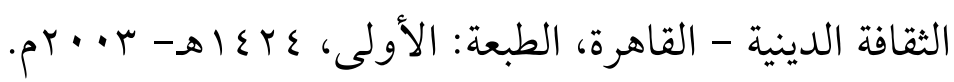
IV - شرح سنن أبي داود، لشهاب الدين أبو العباس أحمد بن حسين بن علي بن

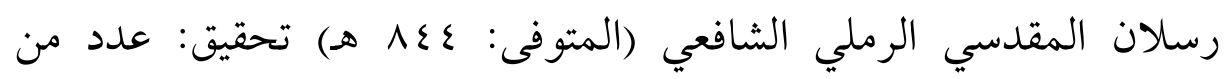
الباحثين بدار الفلاح بإشراف خالد الرباط- نشر: دار الفلاح للبحث العلمي

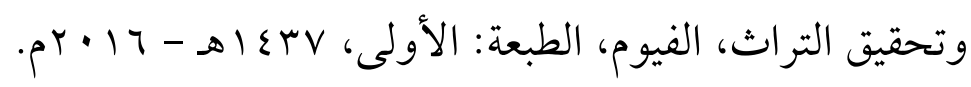

11 - شرح سنن النسائي المسمى ((ذخيرة العقبى في شرح المجتبى)، لمحمد بن

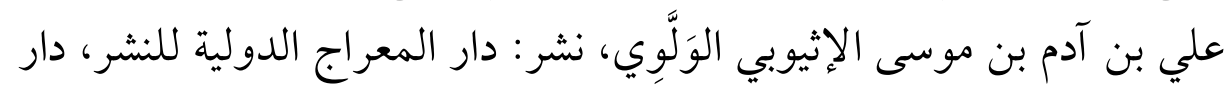

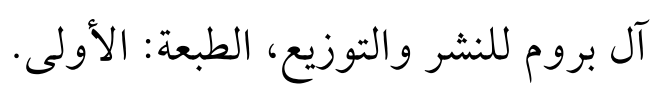

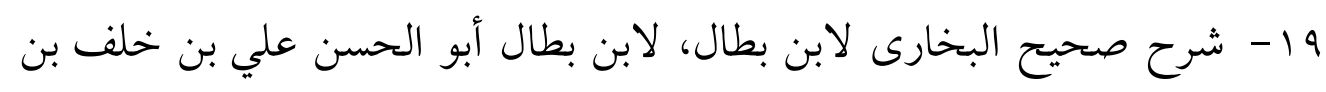

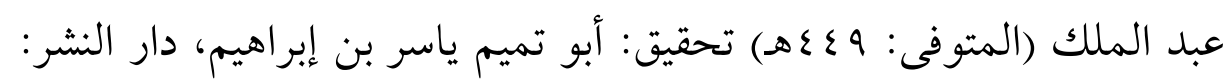

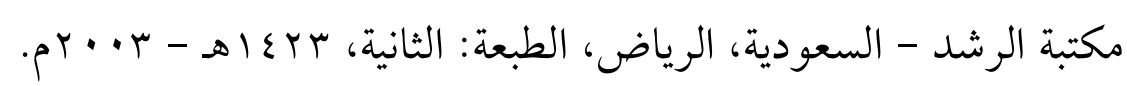

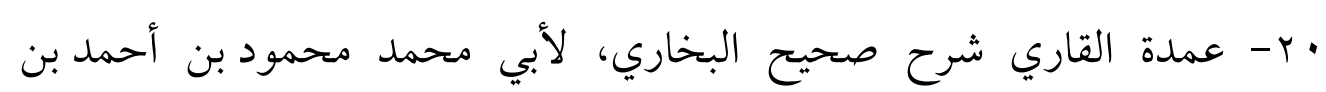
موسى بن أحمد بن حسين الغيتابى الحنفى بدر الدين العينى (المتوفى لتى

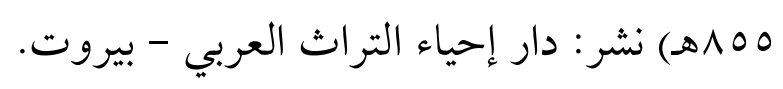

اب- فتح الباري شرح صحيح البخاري، لأحمد بن علي بن حجر أبو الفضل

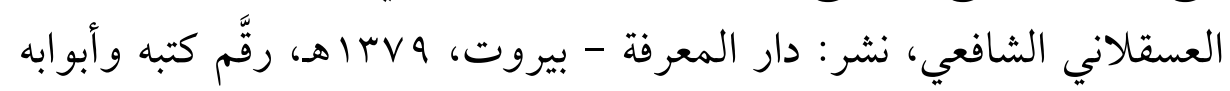
وأحاديثه: محمد فؤاد عبد الباقي، قام بإخراجه وصححه و أشرف على طبعه: محب الدين الخطيب.

r r- فيض القدير شرح الجامع الصغير، لزين الدين محمد المدعو بعبد الرؤوف بن تاج العارفين بن علي بن زين العابدين الحدادي ثم المناوي القاهري (المتوفى: ابم+1اهـ) نشر: المكتبة التجارية الكبرى - مصر، الطبعة:

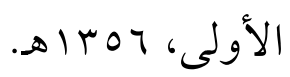


ب - المتواري علي تراجم أبواب البخاري، لأحمد بن محمد بن منصور بن القاسم بن مختار القاضي، أبو العباس ناصر الدين ابن المنير الجذامي

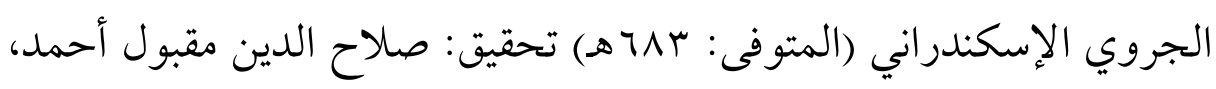
نشر: مكتبة المعلا - الكويت، بدون طبعة، وبدون تاريخ.

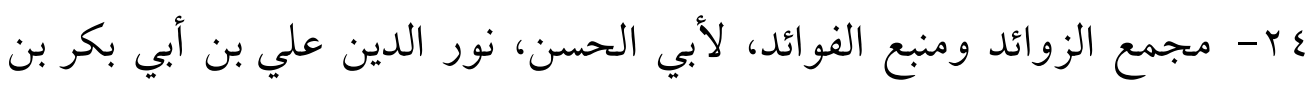

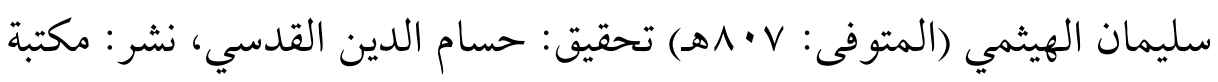

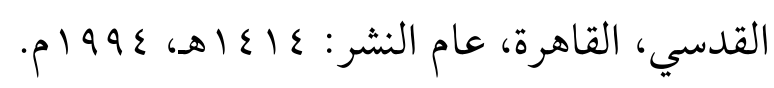

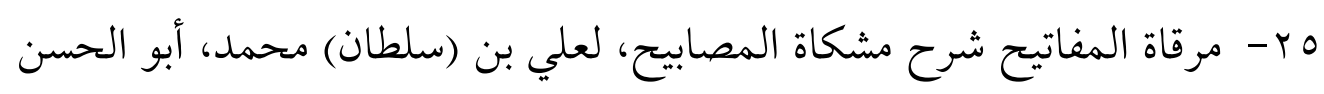

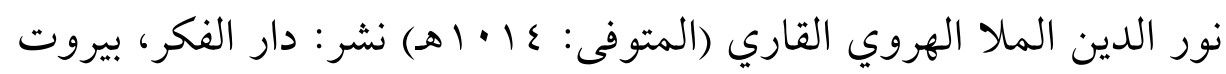

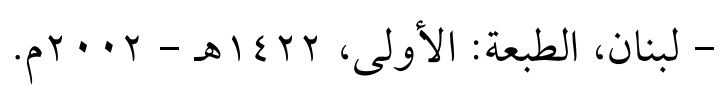

צr- مسند أبي داود الطيالسي، لأبي داود سليمان بن داود بن الجارود الطيالسي

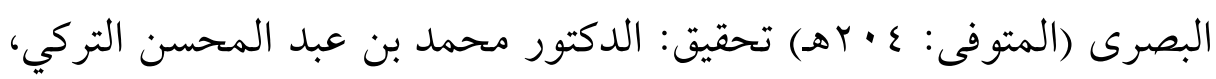

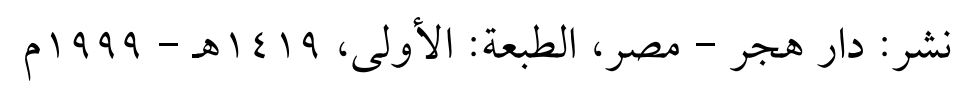

V V - المسند الصحيح المختصر بنقل العدل عن العدل إلى رسول الله

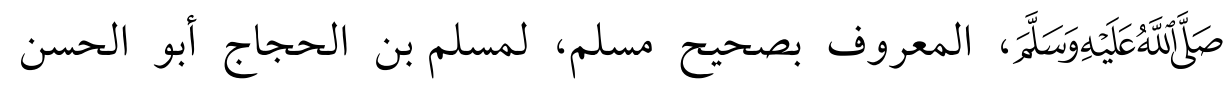
القشيري النيسابوري (المتوفى: الجr هـ) تحقيق: محمد فؤاد عبد الباقي، نشر:

$$
\text { دار إحياء التراث العربي - بيروت. }
$$

^ץ- المصنف، لأبي بكر، عبد الرزاق بن همام بن نافع الحميري اليماني

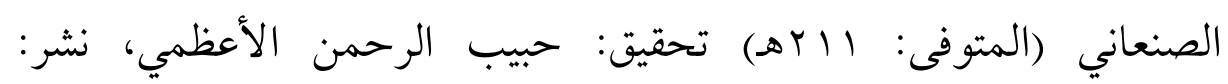
المجلس العلمي- الهند، ويطلب من: المكتب الإسلامي - بيروت، الطبعة:

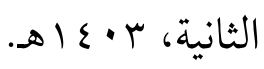

وץ- المعتصر من المختصر من مشكل الآثار، ليوسف بن موسى بن محمد، أبو 
المحاسن جمال الدين المَلَطي الحنفي (المتوفى: ب.یهـ) نشر: عالم

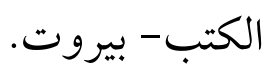

• r- المنتقى شرح الموطأ، لأبي الوليد، سليمان بن خلف بن سعد بن أيوب بن

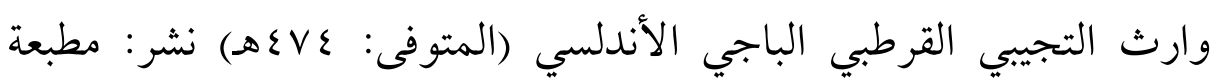

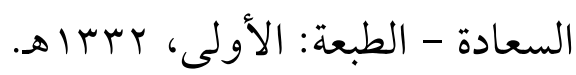

اب- الموطأ، لمالك بن أنس بن مالك بن عامر الأصبحي المدني (المتوفى:

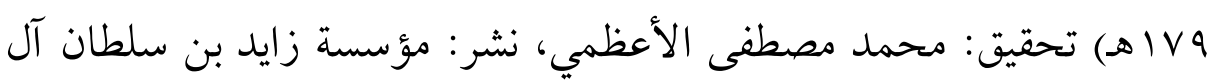

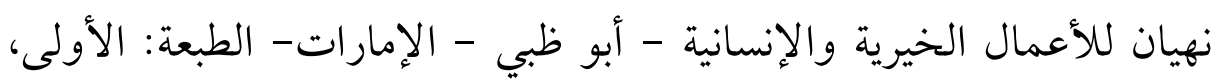

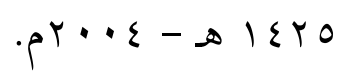

r r- نصب الراية لأحاديث الهداية مع حاشيته بغية الألمعي في تخريج الزيلعي، لجمال الدين أبو محمد عبد الله بن يوسف بن محمد الزيلعي (المتوفى:

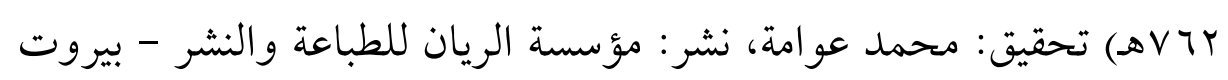

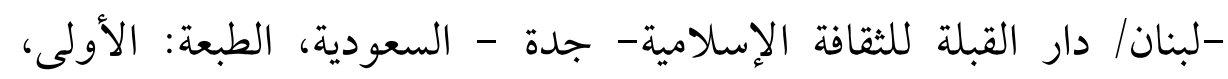

$$
\text { م 199V/ه1:11 }
$$

rr- نيل الأوطار، لمحمد بن علي بن محمد بن عبد الله الشوكاني اليمني (المتوفى: ·لمبا(هـ) تحقيق: عصام الدين الصبابطي، نشر: دار الحديث،

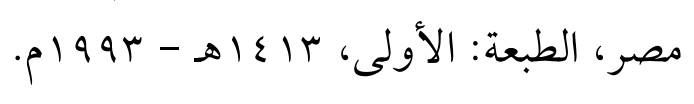

\section{علوم اللفة: - na}

ع ب- تاج العروس من جواهر القاموس، لمحمّد بن محمّد بن عبد الرزّاق

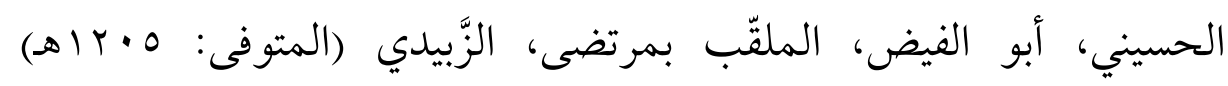
تحقيق: مجموعة من المحققين، نشر: دار الهداية. ه 
هـ) تحقيق: الدكتور كامل سلمان الجبوري- نشر: دار الكتب العلمية، بيروت

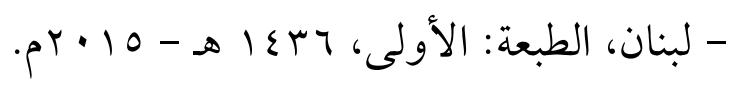
جr- الذخيرة، لأبي العباس، شهاب الدين أحمد بن إدريس بن عبد الرحمن

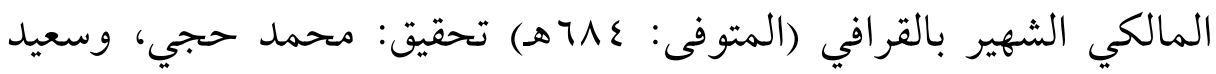
أعراب، ومحمد بو خبزة- نشر: دار الغرب الإسلامي- بيروت، الطبعة:

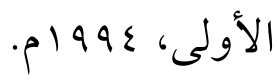

Vr- شمس العلوم ودواء كلام العرب من الكلوم، لنشوان بن سعيد الحميرى اليمني (المتوفى: roVrهـ) تحقيق: د حسين بن عبد الله العمري - مطهر بن علي الإرياني - د يوسف محمد عبد الله، نشر: دار الفكر المعاصر (بيروت -

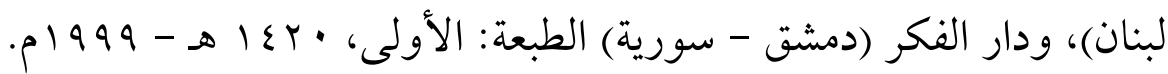
^ץ- طلبة الطلبة، لعمر بن محمد بن أحمد بن إسماعيل، أبو حفص، نجم الدين

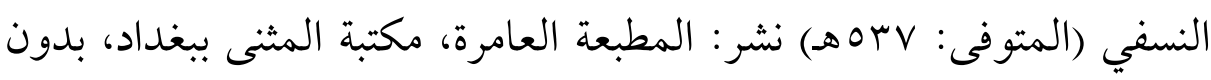

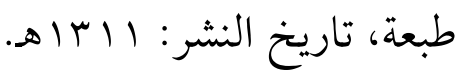
ه r- الكليات معجم في المصطلحات والفروق اللغوية، لأيوب بن موسى الحسيني القريمي الكفوي، أبو البقاء الحنفي (المتوفى: عqه •إهـ) تحقيق: عدنان درويش - محمد المصري- نشر: مؤسسة الرسالة- بيروت.

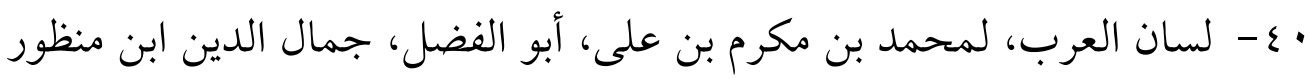

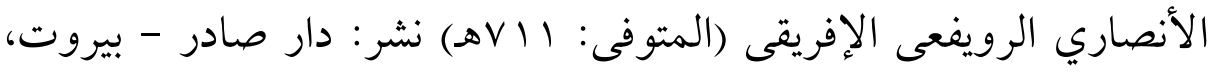

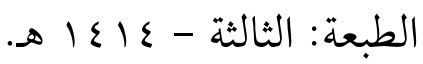

اع - المصباح المنير في غريب الشرح الكبير، لأحمد بن محمد بن علي الفيومي ثم الحموي، أبو العباس (المتوفى: نحو • •Vه ) نشر: المكتبة العلميةبيروت، بدون طبعة، وبدون تاريخ. 
r ع - المغرب، لناصر بن عبد السيد أبى المكارم ابن على، أبو الفتح، برهان الدين

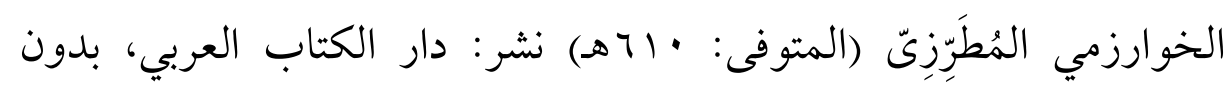

طبعة وبدون تاريخ.

\section{أصول الثقه :}

rع - الموافقات، لإبر اهيم بن موسى بن محمد اللخمي الغرناطي الشهير بالشاطبي

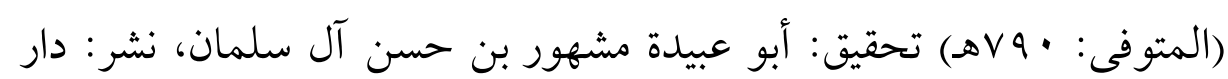

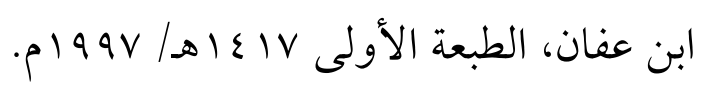

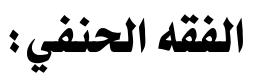

ع - الاختيار لتعليل المختار، لعبد الله بن محمود بن مودود الموصلي البلدحي،

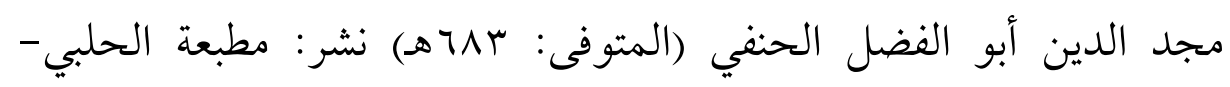

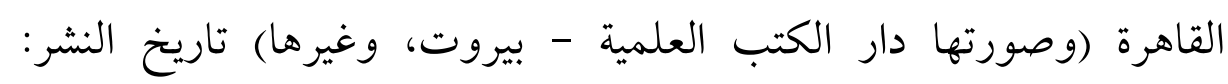
. $194 \mathrm{r}-\mathrm{s} 1 \mathrm{p} 0 \mathrm{r}$

ه - - بدائع الصنائع في ترتيب الشرائع، لعلاء الدين، أبو بكر بن مسعود بن أحمد

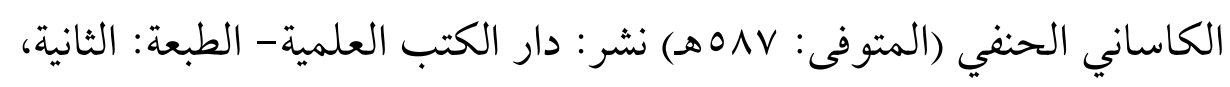
.

جع - تبين الحقائق شرح كنز الدقائق وحاشية الشِّلْبِيّ، لعثمان بن علي بن محجن

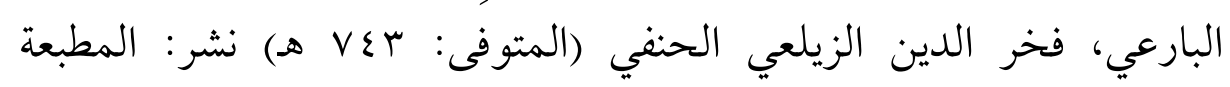

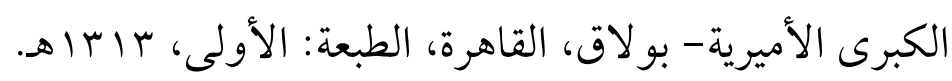

V V - الجوهرة النيرة، لأبو بكر بن علي بن محمد الحدادي العبادي الزَّبيديّ اليمني

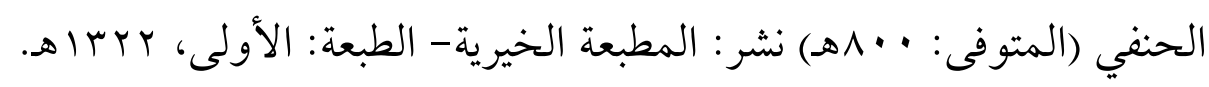

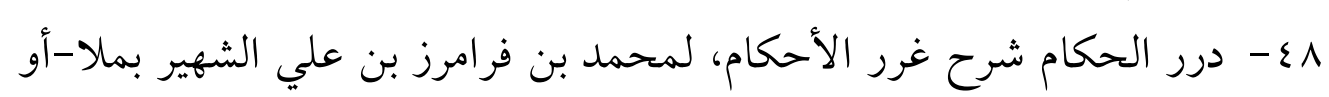


منلا أو المولى - خسرو (المتوفى: 110هــ نشر: دار إحياء الكتب العربيةبدون طبعة وبدون تاريخ.

هـ - رد المحتار على الدر المختار، لابن عابدين، محمد أمين بن عمر بن عبد العزيز عابدين الدمشقي الحنفي (المتوفى: ror اهـه) نشر: دار الفكر -

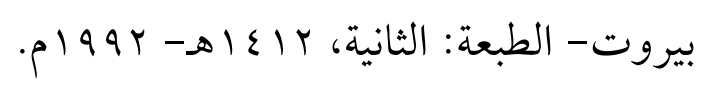

•- - شرح مختصر الطحاوي، لأحمد بن علي أبو بكر الرازي الجصاص الحنفي (المتوفى: • PV هـ) تحقيق: مجموعة من المحققين، نشر: دار البشائر

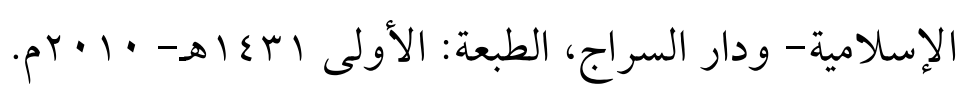

اه- العناية شرح الهداية، لمحمد بن محمد بن محمود، أكمل الدين أبو عبد الله ابن الشيخ شمس الدين ابن الشيخ جمال الدين الرومي البابرتي (المتوفى:

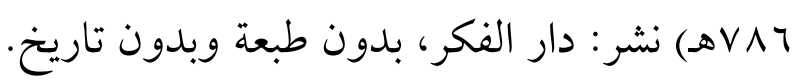

ro - المبسوط، لمحمد بن أحمد بن أبي سهل شمس الأئمة السرخسي (المتوفى:

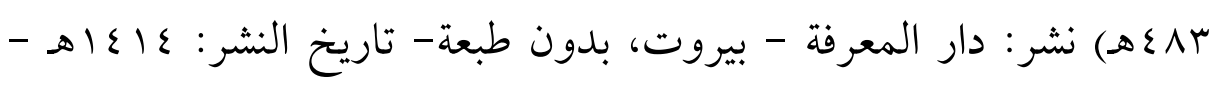
p $199 \mu$

ro - مجمع الأنهر في شرح ملتقى الأبحر، لعبد الرحمن بن محمد بن سليمان

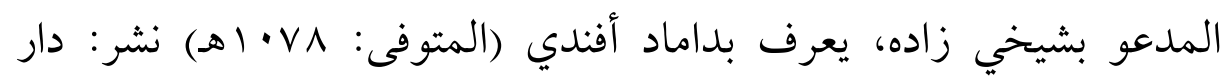

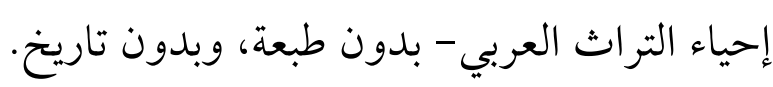

\section{الفقه المالكي: - المي}

عه - أسهل المدارك ((شرح إرشاد السالك في مذهب إمام الأئمة مالك))، لأبو

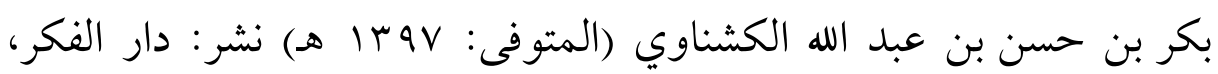
بيروت - لبنان، الطبعة: الثانية، بدون تاريخ.

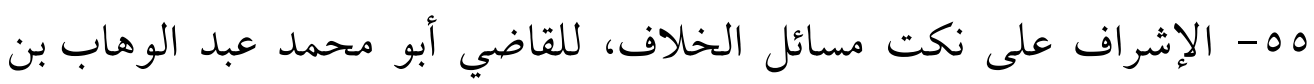


علي بن نصر البغدادي المالكي (rr \&هـ) تحقيق: الحبيب بن طاهر، نشر: دار

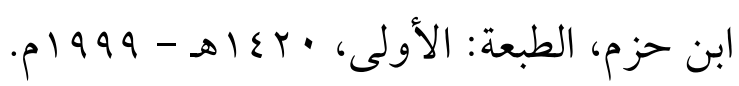

10 - بداية المجتهد ونهاية المقتصد، لأبي الوليد، محمد بن أحمد بن محمد بن

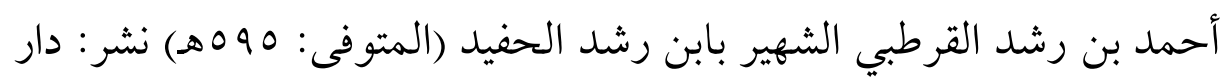

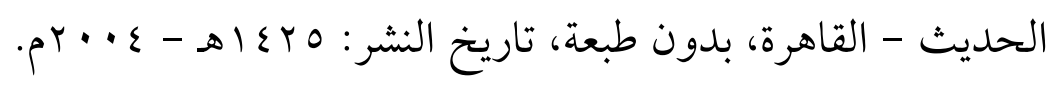

V V - البيان والتحصيل والشرح والتوجيه والتعليل لمسائل المستخرجة، لأبي

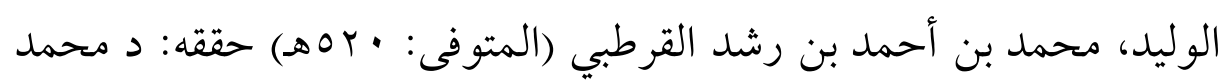
حجي وآخرون، نشر: دار الغرب الإسلامي، بيروت - لبنان، الطبعة: الثانية

$$
\text { . } 9191-81 \varepsilon \cdot \Lambda
$$

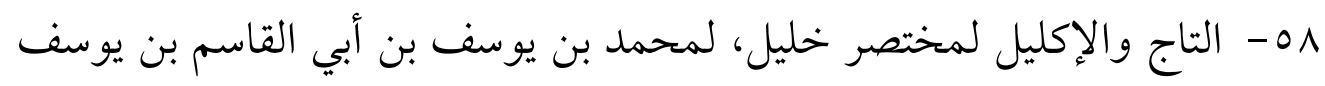

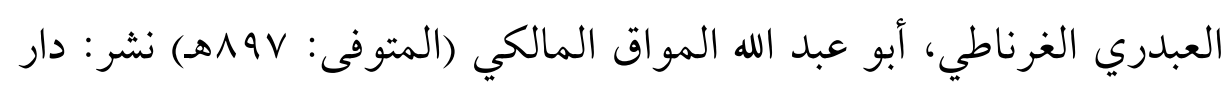

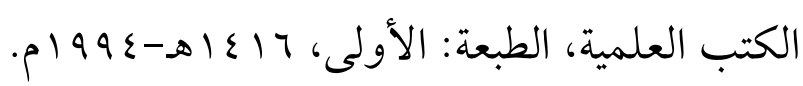

هo- التبصرة، لعلي بن محمد الربعي، أبو الحسن، المعروف باللخمي (المتوفى: \&VA

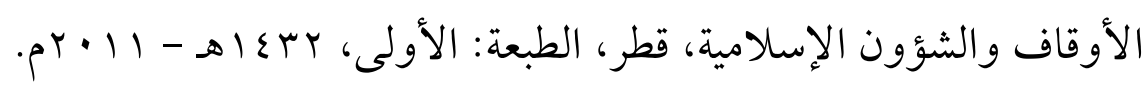

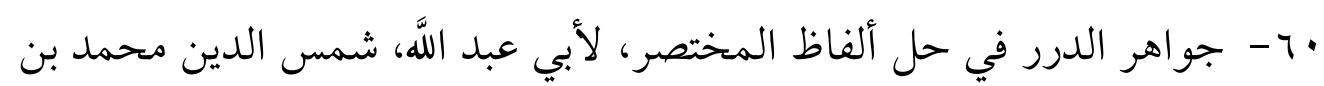

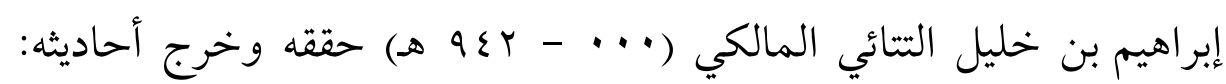
الدكتور أبو الحسن، نوري حسن حامد المسلاتي، نشر: دار ابن حزم،

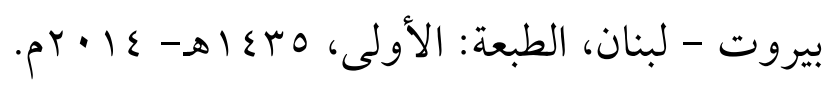

اج - حاشية الدسوقي على الشرح الكبير، لمحمد بن أحمد بن عرفة الدسوقي المالكي (المتوفى: · r ا أهـ) نشر : دار الفكر - بدون طبعة وبدون تاريخ.

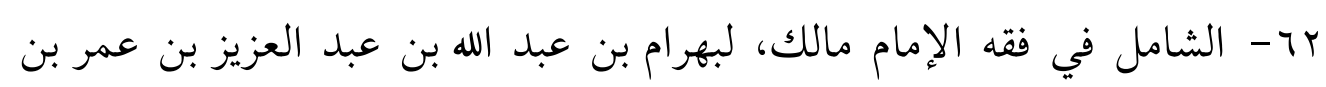


عوض، أبو البقاء، تاج الدين السلمي الدَّمِيرِيّ الدِّمْيَاطِيّ المالكي (المتوفى:

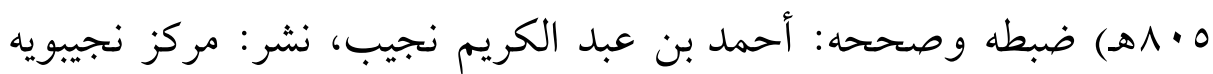

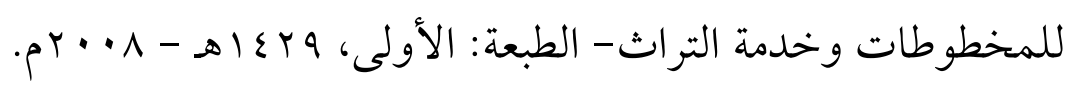
rا7- الفواكه الدواني على رسالة ابن أبي زيد القيرواني، لأحمد بن غانم (أو غنيم) بن سالم ابن مهنا، شهاب الدين النفراوي الأزهري المالكي (المتوفى :

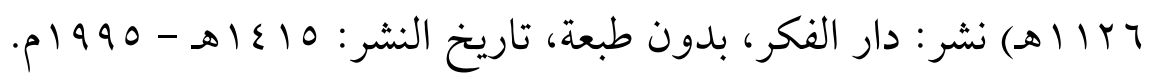
ع - القوانين الفقهية، لأبو القاسم، محمد بن أحمد بن محمد بن عبد الله، ابن

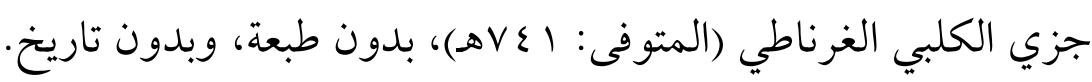
ه7- لغة السالك لأقرب المسالك إلى مذهب الإمام مالك. المعروف بحاشية الصاوي على الشرح الصغير (الشرح الصغير هو شرح الشيخ الدردير لكتابه

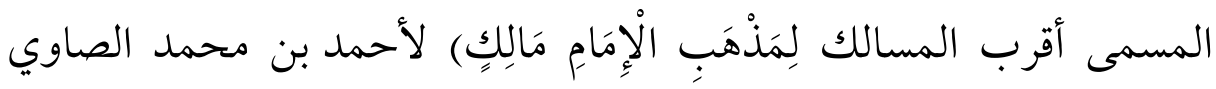
المالكي، صححه: لجنة برئاسة الشيخ أحمد سعد علي، نشر: مكتبة مصطفى لئل

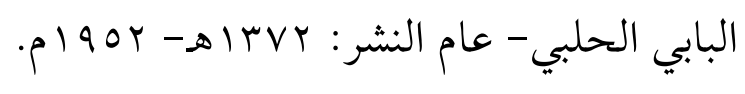

7r- مختصر العلامة خليل، خليل بن إسحاق بن موسى، ضياء الدين الجندي

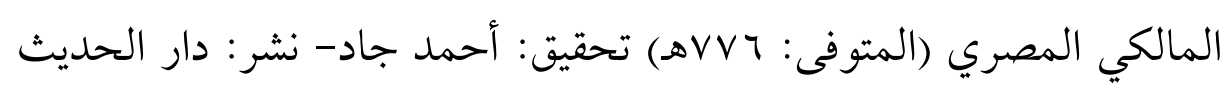

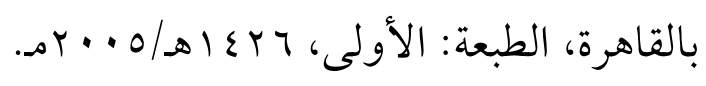

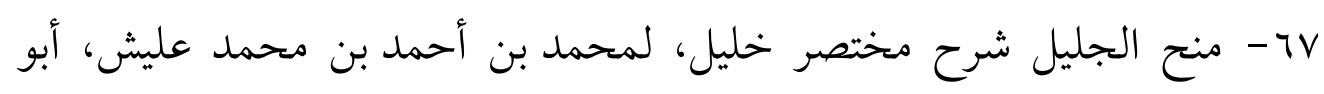

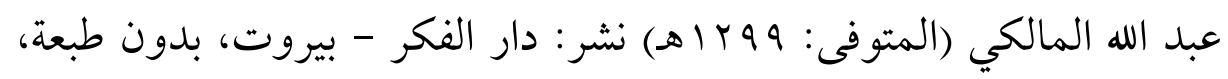

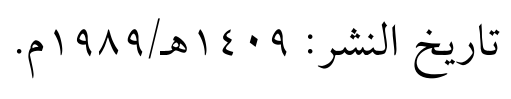

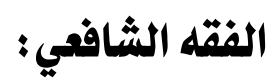

11 - أسنى المطالب في شرح روض الطالب، لزكريابن محمد بن زكريا

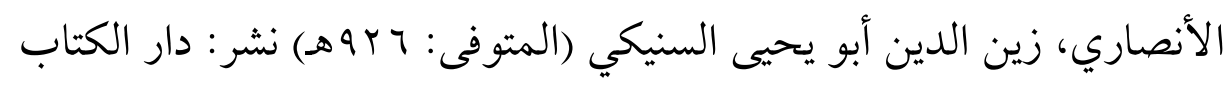


الإسلامي، بدون طبعة، وبدون تاريخ.

19 - إعانة الطالبين على حل ألفاظ فتح المعين (هو حاشية على فتح المعين بشرح قرة العين بمهمات الدين) لأبي بكر (المشهور بالبكري) عثمان بن

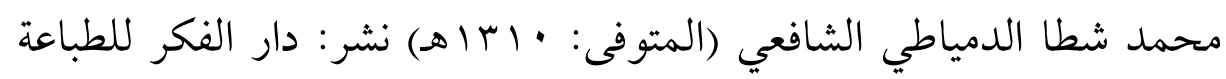

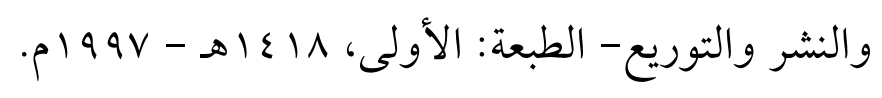

•

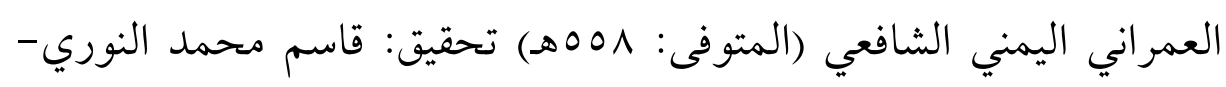

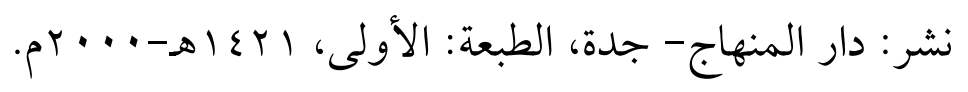
ا - تحفة الحبيب على شرح الخطيب = حاشية البجيرمي على الخطيب،

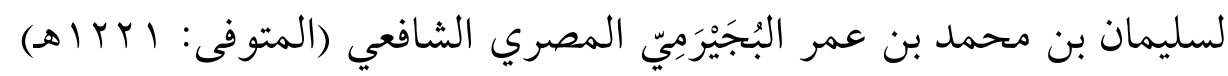

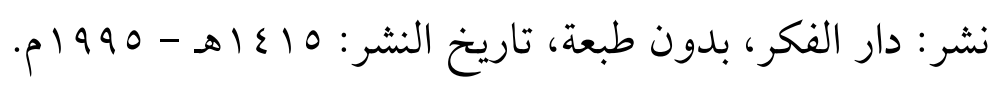
r - تحفة المحتاج في شرح المنهاج، لأحمد بن محمد بن علي بن حجر

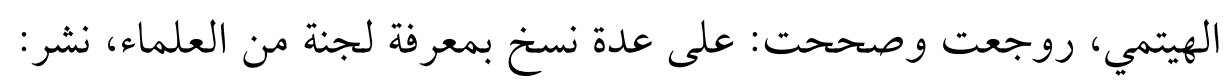

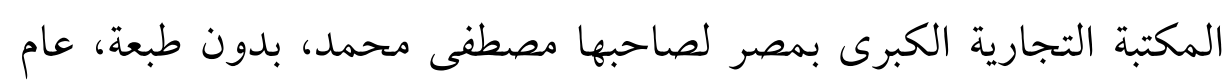

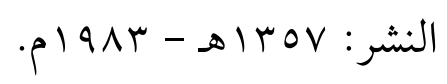

r جr- جواهر العقود ومعين القضاة والموقعين والشهود، لشمس الدين محمد بن

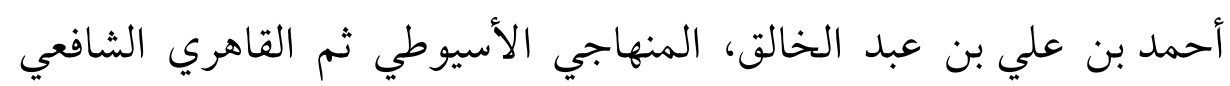

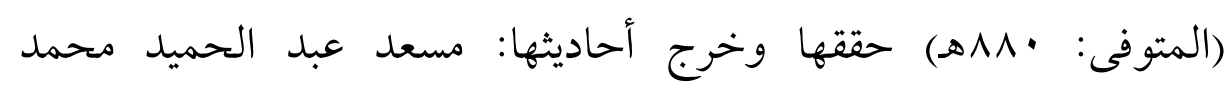

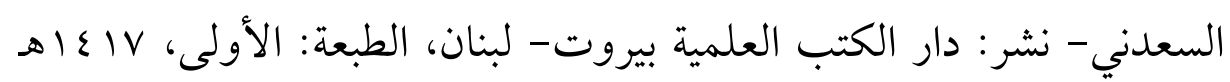

$$
\text { . } 1997 \text { - }
$$

ع - حاشيتا قليوبي وعميرة، لأحمد سلامة القليوبي وأحمد البرلسي عميرة-

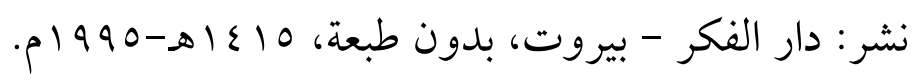


ه - الحاوي الكبير في فقه مذهب الإمام الشافي (وهو شرح مختصر المزني) لأبي الحسن، علي بن محمد بن محمد بن حبيب البصري البغدادي، الشهير

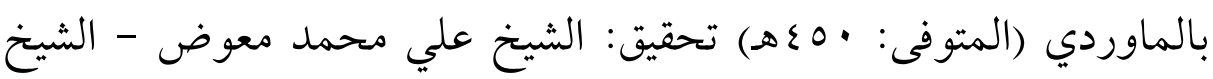
عادل أحمد عبد الموجود، نشر: دار الكتب العلمية، بيروت - لبنان، الطبعة:

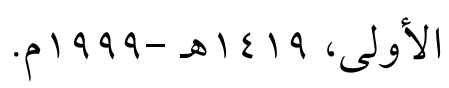

TV V حلية العلماء في معرفة مذاهب الفقهاء، لمحمد بن أحمد بن الحسين بن عمر، أبو بكر الشاشي القفال الفارقيّ، الملقب فخر الإسلام، المستظهري الشافعي (المتوفى: V•0هـ) تحقيق: د. ياسين أحمد إبراهيم درادكة، نشر:

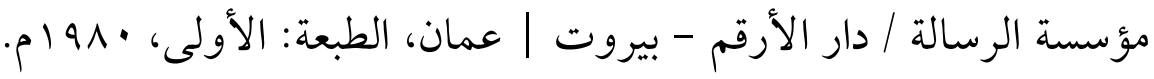

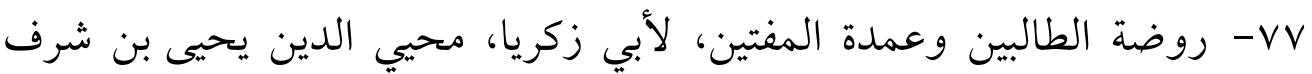

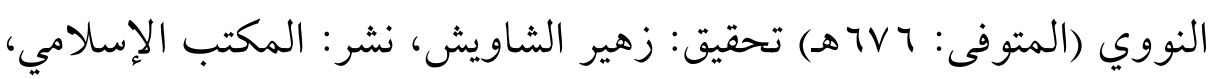

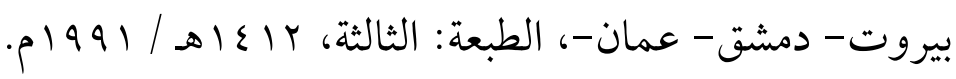
- VA

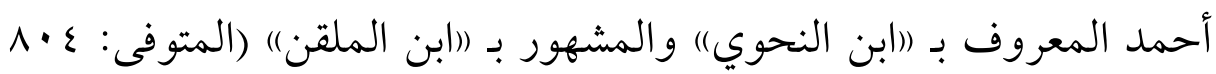

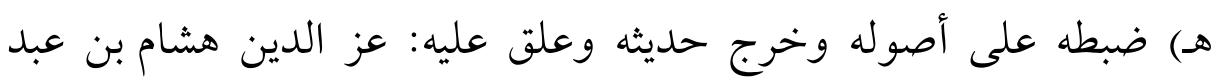

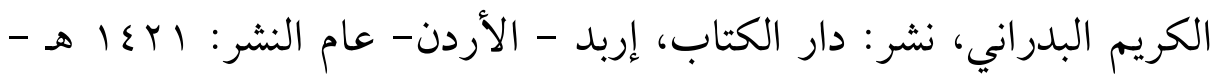

$$
\text { • r. I }
$$

q V - فتح العزيز بشرح الوجيز = الشرح الكبير [وهو شرح لكتاب الوجيز في الفقه

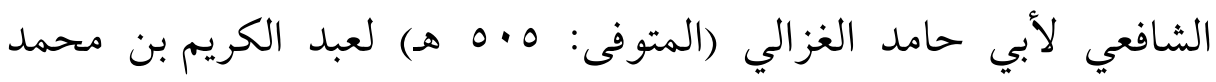
الرافعي القزويني (المتوفى: بrا7هـ) نشر: دار الفكر، بدون طبعة، وبدون تاريخ. • ^- كفاية النبيه في شرح التنبيه، لأحمد بن محمد بن علي الأنصاري، أبو 
العباس، نجم الدين، المعروف بابن الرفعة (المتوفى: · لهـ) تحقيق: مجدي

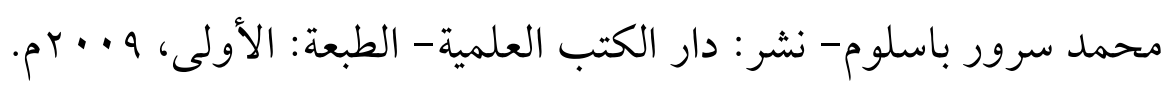
1 - مغني المحتاج إلى معرفة معاني ألفاظ المنهاج، لشمس الدين، محمد بن

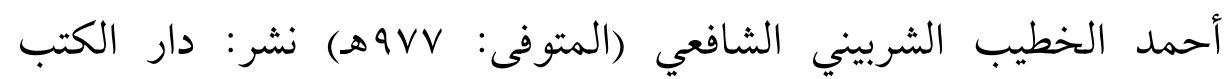

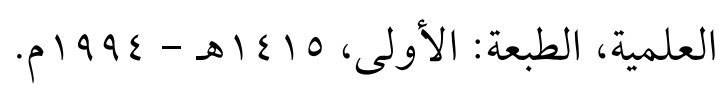

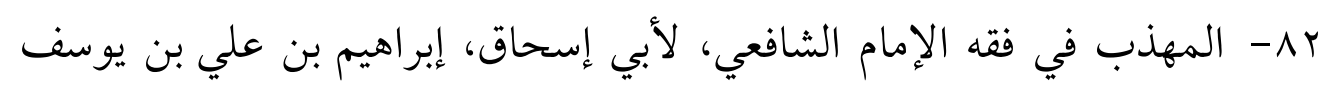

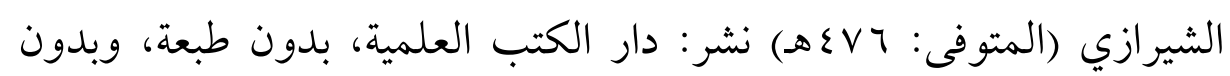

تاريخ.

rی- النجم الوهاج في شرح المنهاج، لكمال الدين، محمد بن موسى بن

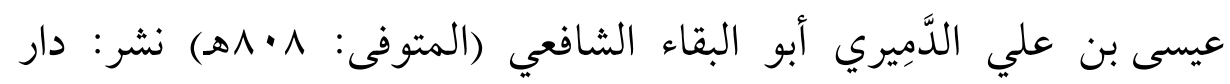

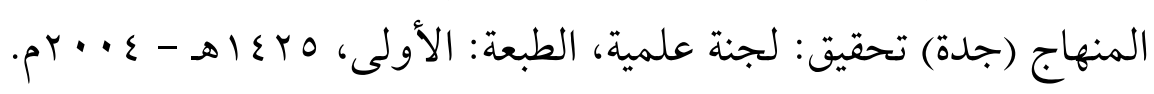

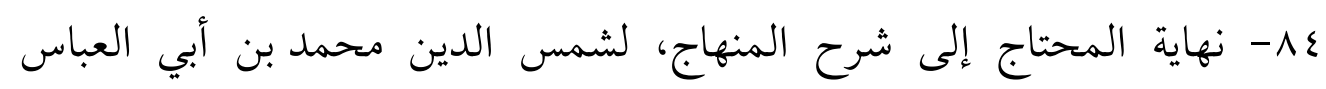

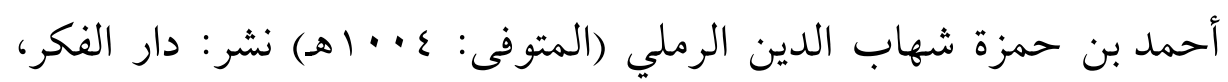

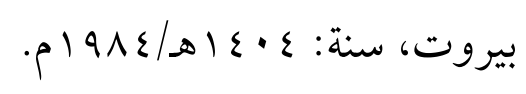

01- نهاية المطلب في دراية المذهب، لعبد الملك بن عبد الله بن يوسف بن

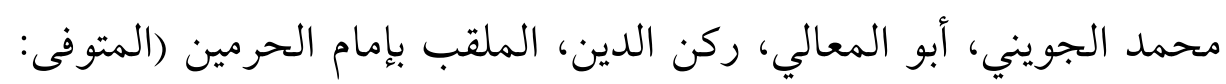

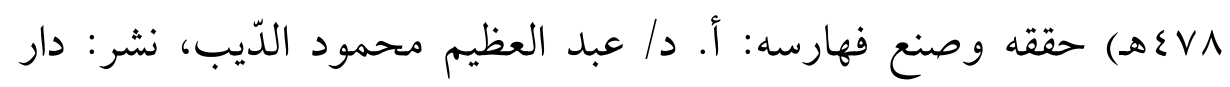

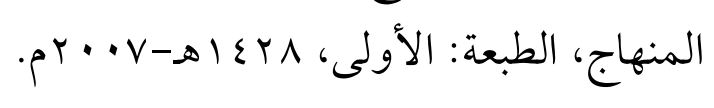

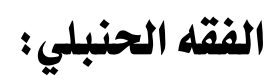

7 - الإنصاف في معرفة الراجح من الخلاف (المطبوع مع المقنع والشرح الكبير)

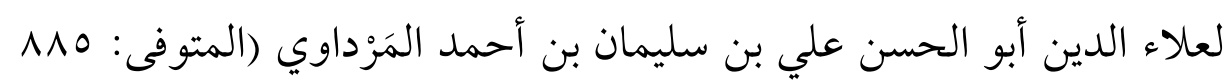
هـ) تحقيق: الدكتور عبد الله بن عبد المحسن التركي - الدكتور عبد الفتاح 
محمد الحلو- نشر: هجر للطباعة والنشر والثوزيع والإعلان بالقاهرة،

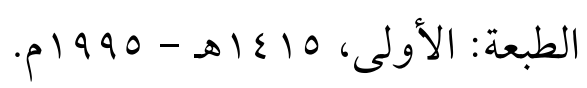

1 v

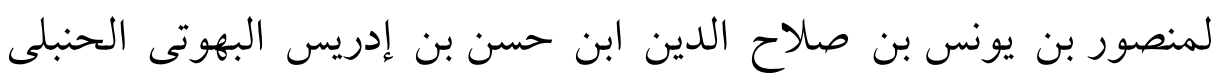

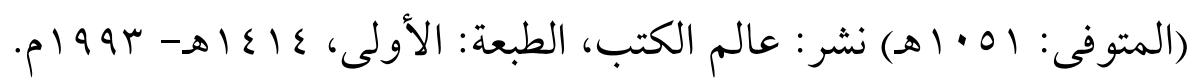
1^- الدلائل والإشارات على أخصر المختصرات لمحمد بن بدر الدين البلباني

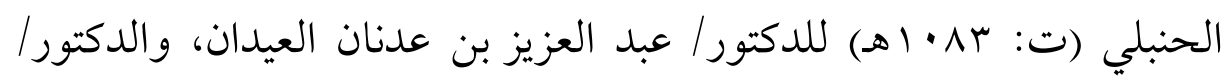
أنس بن عادل اليتامى، نشر: دار الركائز للنشر والتوزيع - الكويت، دار أطلس الخضراء للنشر والتوزيع، الرياض - المملكة العربية السعودية،

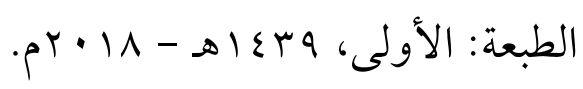

ه1 - شرح الزركشي، لشمس الدين محمد بن عبد الله الزركشي المصري الحنبلي

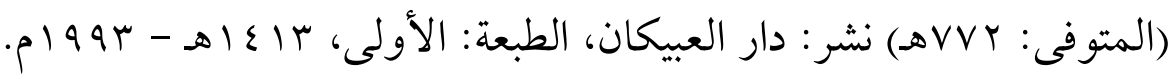

• ه- الشرح الكبير على متن المقنع، لعبد الرحمن بن محمد بن أحمد بن قدامة

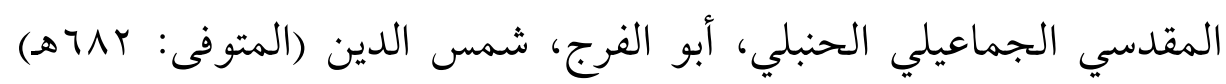

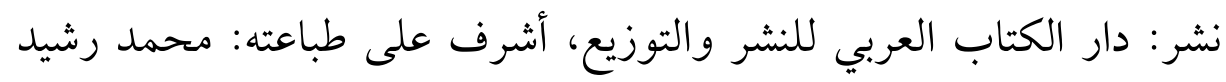

$$
\text { رضا صاحب المنار. }
$$

1 - العدة شرح العمدة، لعبد الرحمن بن إبراهيم بن أحمد، أبو محمد بهاء الدين

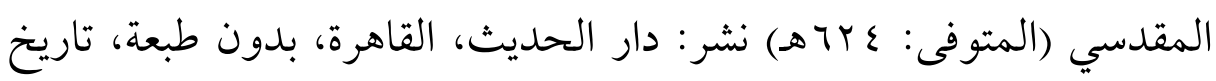

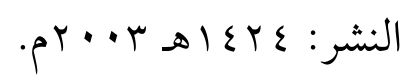

rه - الكافي في فقه الإمام أحمد، لأبي محمد، موفق الدين عبد الله بن أحمد بن محمد بن قدامة الجماعيلي المقدسي ثم الدمشقي الحنبلي، الشهير بابن

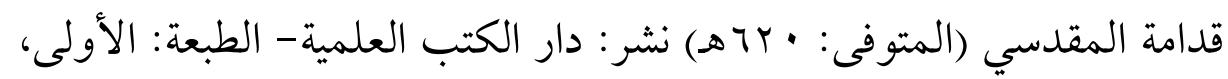


$. p 199 \varepsilon-\infty 1 \varepsilon \mid \varepsilon$

به- كشاف القناع عن متن الإقناع، لمنصور بن يونس بن صالح الدين ابن حسن بن إدريس البهوتى الحنبلى (المتوفى: 01 • اهـ) نشر: دار الكتب العلمية، بدون طبعة، وبدون تاريخ. ع - المبدع في شرح المقنع، لإبراهيم بن محمد بن عبد الله بن محمد ابن مفلح، أبو إسحاق، برهان الدين (المتوفى: ع^^هـ) نشر: دار الكتب العلمية، بيروت

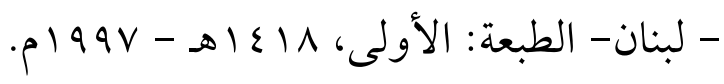

هو- مطالب أولي النهى في شرح غاية المنتهى، لمصطفى بن سعد بن عبده السيوطي شهرة، الرحيبانى مولدا ثم الدمشقي الحنبلي (المتوفى: بع أهـ) نشر: المكتب الإسلامي، الطبعة: الثانية، 0 اع اهـ - ع 99 ام. ج ه - المغني، لأبي محمد موفق الدين عبد الله بن أحمد بن محمد بن قدامة الجماعيلي المقدسي ثم الدمشقي الحنبلي، الثهير بابن قدامة المقدسي (المتوفى : · با7هـ) نشر : مكتبة القاهرة، بدون طبعة.

Q لمحفوظ بن أحمد بن الحسن، أبو الخطاب الكلوذاني - تحقيق: عبد اللطيف هميم - ماهر ياسين الفحل، نشر: مؤسسة غراس للنشر والتوزيع- الطبعة:

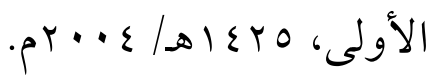

\section{مراجع الفقه العاه، والفتاوى:}

19 - الإجماع، لمحمد بن إبراهيم بن المنذر النيسابوري، تحقيق ودراسة: د. فؤاد عبد المنعم أحمد، نشر: دار المسلم للنشر والتوزيع، الطبعة: الأولى لدار

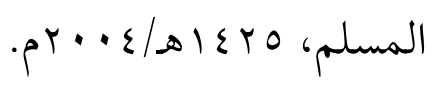

9 - اختلاف الفقهاء، لأبي عبد الله، محمد بن نصر بن الحجاج المَزْوَزِي 
(المتوفى: ع צ هـ) تحقيق: الدكتور/ محمد طاهر حكيم، نشر: أضواء

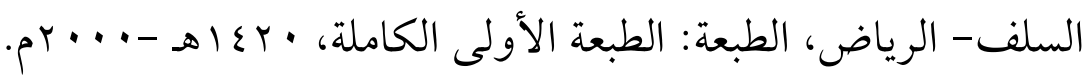
• . - الإشراف على مذاهب العلماء، لأبي بكر، محمد بن إبراهيم بن المنذر

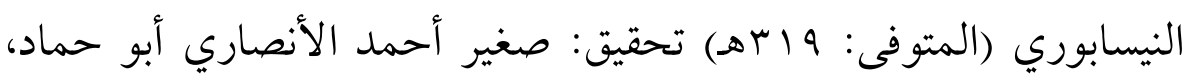
نشر: مكتبة مكة الثقافية، رأس الخيمة - الإمارات العربية المتحدة، الطبعة:

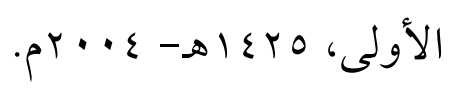

1· - العقود الدرية في تنقيح الفتاوى الحامدية، لابن عابدين، محمد أمين بن

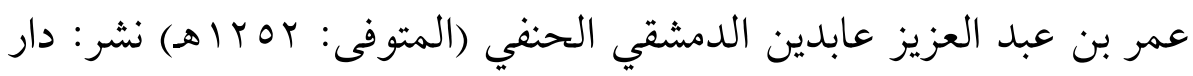
المعرفة، بدون طبعة، وبدون تاريخ.

ץ+1- الفتاوى الفقهية الكبرى، لأحمد بن محمد بن علي بن حجر الهيتمي السعدي الأنصاري، شهاب الدين شيخ الإسلام، أبو العباس (المتوفى: ع هـ علي الفاكهي المكي (المتوفى بهیهـ) نشر المكتبة الإسلامية. ب. 1 - الفتاوى المهدية في الوقائع المصرية، لشيخ الإسلام ومفتي الديار المصرية محمد العباسي، الفقيه الحنفي الأزهري المصري (المتوفى سنة: 0 ابـاهـ) تحقيق: أبي عبد الله محمد حسن محمد حسن إسماعيل الشافعي الشيخ القاهري المصري، دار الكتب العلمية ببيروت- لبنان، بدون طبعة، وبدون تاريخ. ع • 1 - فتاوي الخليلي على المذهب الشافعي، لمحمد بن محمد، ابن شَرَف الدين الخليلي الشافعيّ القادري (المتوفى: V ع I الهـ) طبعة مصرية قديمة. ○• - فتح العلي المالك في الفتوى على مذهب الإمام مالك، لمحمد بن

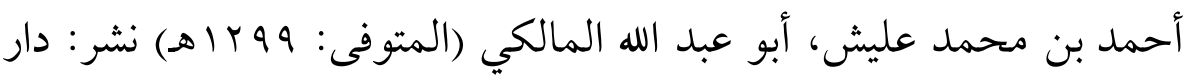


المعرفة، بدون طبعة، وبدون تاريخ.

4· 1- المحلى بالآثار، لأبي محمد علي بن وبدون تاريخ. أحمد بن سعيد بن حزم الأندلسي

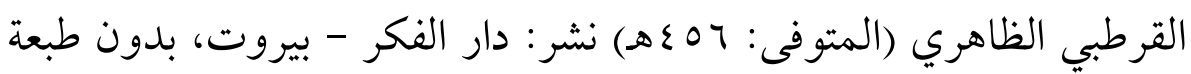

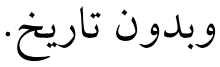

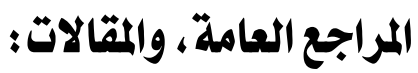

V• إ بدائع الفوائد، لأبي عبد الله، محمد بن أبي بكر بن أيوب ابن قيم الجوزية

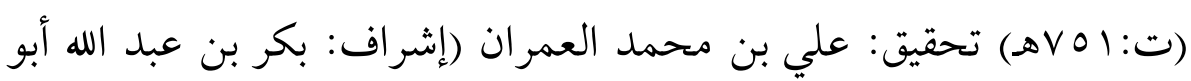

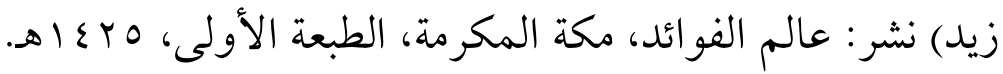

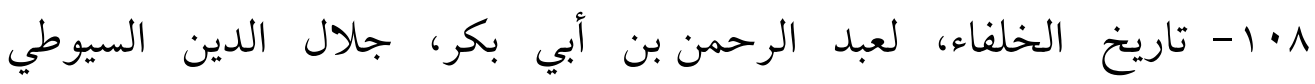

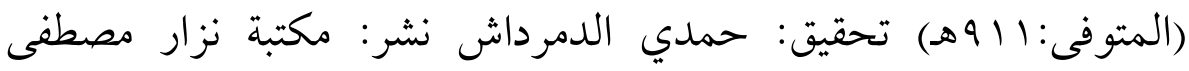

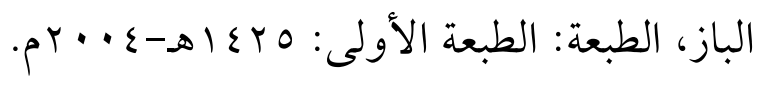

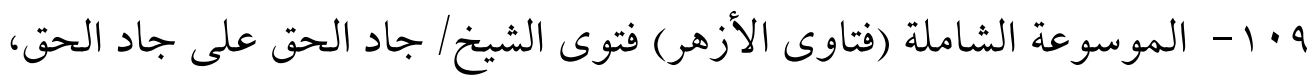

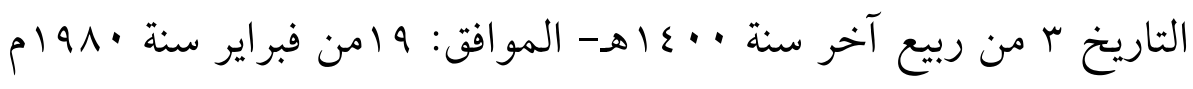

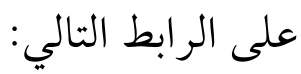

http://islamport.com/d/2/ftw/1/11/500.html

•11- مقال بجريدة الرياض، بعنوان: ما في قلوبهم لا يمحوه الزمن حتى وإن

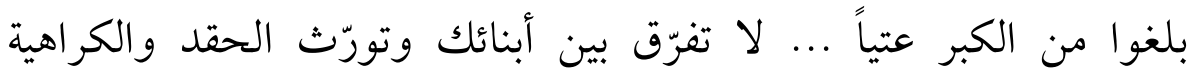

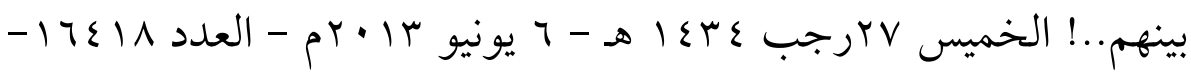
إعداد- سحر الرملاوي. ينظر النسخة الالكترونية على الرابط النالي: http://www.alriyadh.com/841515 111- مقال بجريدة الخليج، بعنوان: الإسلام يأمر بالعدل حتى في الابتسامة 


$$
\text { والرابط التالي: - حصاد مر للتمييز بين الأبناء، تاريخ النشر: · ب/ه/ع ا • بم على }
$$

http://www.alkhaleej.ae/supplements/page/b4b9ae91-abac4599-863e-50372d57104f

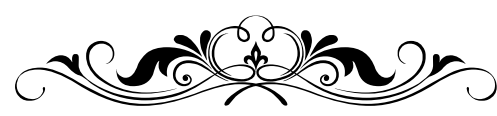

